\author{
Universidade de São Paulo \\ Instituto de Física
}

\title{
Estudo das interações proteína-proteína, proteína-membranas e proteína-agentes desnaturantes por espalhamento de raios-X a baixos ângulos
}

Elisa Morandé Sales

Orientadora: Prof ${ }^{\mathrm{a}}$ Dr $^{\mathrm{a}}$ Rosangela Itri

Tese de doutorado apresentada ao Instituto de Física da Universidade de São Paulo, como requisito parcial para a obtenção do título de Doutora em Ciências.

Banca Examinadora:

Prof(a). Dr(a). Rosangela Itri - orientadora (IFUSP)

Prof. Dr. José Luiz de Souza Lopes (IFUSP)

Prof. Dr. Leandro Ramos Souza Barbosa (IFUSP)

Prof. Dr. Luis Gustavo Dias (FFCLRP/USP)

Prof. Dr. Pietro Ciancaglini (FFCLRP/USP)

São Paulo

2018 


\section{FICHA CATALOGRÁFICA \\ Preparada pelo Serviço de Biblioteca e Informação do Instituto de Física da Universidade de São Paulo}

Sales, Elisa Morandé

Estudo das interações proteína-proteína, proteína-membranas e proteína-agentes desnaturantes por espalhamento de raios-X a baixos ângulos. São Paulo, 2018.

Tese (Doutorado) - Universidade de São Paulo. Instituto de Física, Depto. de Física Aplicada.

Orientador: Prof ${ }^{\mathrm{a}} \mathrm{Dr}^{\mathrm{a}}$ Rosangela Itri

Área de Concentração: Física da Matéria Condensada

Unitermos: 1. Física; 2. Física da Matéria Condensada; 3. Biofísica Molecular

$\mathrm{USP} / \mathrm{IF} / \mathrm{SBI}-039 / 2018$ 


\section{Agradecimentos}

Gostaria de manifestar meus sinceros agradecimentos:

À Prof. Dra. Rosangela Itri, pela amizade, orientação e apoio desde a iniciação científica ao final do doutorado. Obrigada pela compreensão com as minhas limitações devido ao trabalho e problemas de saúde;

A minha família, por sempre me incentivarem a ir um pouco mais longe do que eu acreditava ser capaz. Obrigada pelo amor, cuidado e apoio, não apenas nesse período, mas desde sempre;

Ao Leo, por absolutamente tudo, principalmente pela paciência. Por entender que não importa o que eu escreva aqui (ou em qualquer lugar), nenhuma manifestação de agradecimento vai ser capaz de demonstrar o quanto eu sou grata por dividir a vida com você;

Ao Dr. Nelson Alvares Cruz Filho, por salvar minha vida. Se não fosse pelo seu empenho e atenção durante todo o tratamento e nas últimas 7 cirurgias, eu não teria sequer condições físicas de executar qualquer atividade simples do dia-a-dia;

À Dra. Maria Akutsu, ao Dr. Fúlvio Vittorino e ao Instituto de Pesquisas Tecnológicas do Estado de São Paulo, pelo apoio e suporte;

Ao Prof. Dr. Leandro R. S. Barbosa do Instituto de Física da Universidade de São Paulo, pela ajuda com os dados experimentais de BSA e pelas discussões a respeito da teoria SAXS;

Ao Prof. Dr. Francesco Spinozzi da Università Politecnica delle Marche, pelo fornecimento do programa de ajuste GENFIT, assim como pelas explicações e discussões envolvendo o funcionamento do programa, a teoria de SAXS e as análises desenvolvidas;

À Dra. Maytê Bolean, pela ajuda e explicações a respeito das anexinas;

Aos professores Dra. Kaline Coutinho e Dr. Luiz Gustavo Dias, por me direcionarem 
quando foi preciso;

A Gaia, Seiti e Sahba, por serem uma extensão da minha família;

A Rosângela; Rebeca, Ueba, Daniel, Elton e Chico, por sempre estarem presentes, de uma maneira ou de outra;

A Adriana, Cristina, Lúcia, Marcelo, Maria e Melissa, pelo convívio, amizade, apoio, suporte e motivação diários. Obrigada por tornarem o dia-a-dia um constante aprendizado e divertimento;

A André, André Scabbia, Fabiana, Fernanda, Isabela, João, Luciano, Raquel e Peter pela amizade e incentivo;

A Raffaela, Juliana, Gustavo, Andreza, Robert, Maressa, Gabriel e Tayana pela amizade e colaboração;

Ao Carlinhos, por ajudar a manter minha saúde um pouco menos desequilibrada no final do doutorado;

Aos técnicos e secretárias do departamento de Física Aplicada, pelo suporte;

A todos que me apoiaram e ajudaram a tornar esta tese possível;

Ao Laboratório Nacional de Luz Síncrotron (LNLS) pelo uso de suas instalações;

À FAPESP, CAPES e CNPq pelo apoio financeiro. 


\section{Sumário}

\begin{tabular}{ll}
\hline Prefácio & 1
\end{tabular}

1 Estudo do processo de agregação da septina 6G (SEPT6G) e heterodímero $\begin{array}{ll}\text { septina 2G - septina 6G (SEPT2G-SEPT6G) } & 3\end{array}$

1.1 Introdução . . . . . . . . . . . . . . . . . . . . . . . . . 3

1.2 Objetivos $\ldots \ldots \ldots \ldots \ldots \ldots$

1.3 Amostras $\ldots \ldots \ldots \ldots \ldots$

1.4 Análise das curvas de SAXS utilizando combinação de modelos . . . . . . . . 9

1.5 Resultados e Discussão . . . . . . . . . . . . . . . . . . . . . . . . . . . 13

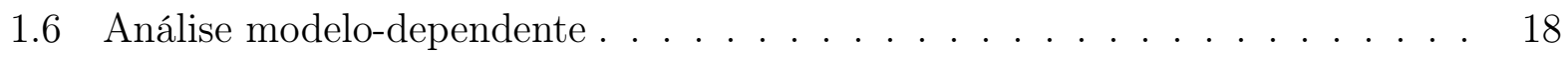

1.6 .1 SEPT6G . . . . . . . . . . . . . . . . . . . . 20

1.6 .2 SEPT2G-SEPT6G . . . . . . . . . . . . . . . . . . . . 24

1.7 Conclusão . . . . . . . . . . . . . . . . . . . . . . . . . . . 30

2 Estudo dos proteolipossomos de anexina V humana (A5) e proteína GPI$\begin{array}{ll}\text { ancorada TNAP } & 31\end{array}$

2.1 Introdução . . . . . . . . . . . . . . . . . . . . . . . . . 31

2.2 Objetivos $\ldots \ldots \ldots \ldots \ldots \ldots \ldots \ldots$

2.3 SAXS no Laboratório Nacional de Luz Síncrotron (LNLS) . . . . . . . . . . 35

2.3 .1 Lamelas e Multilamelas . . . . . . . . . . . . . . . . . . . . . . . . . . 35

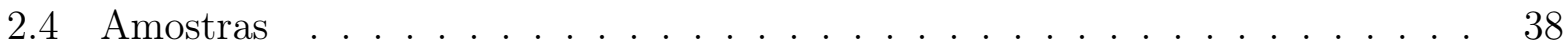

2.5 Resultados e Discussão . . . . . . . . . . . . . . . . . . . . . . . . . . . 40

2.6 Análise de dados com modelo de membranas . . . . . . . . . . . . . . . . . . 49

2.7 Conclusão $\ldots \ldots \ldots \ldots \ldots$

3 Estabilidade térmica da albumina soro bovina (BSA) frente a dois agentes $\begin{array}{ll}\text { desnaturantes: SDS e uréia } & 57\end{array}$

3.1 Introdução . . . . . . . . . . . . . . . . . . . . . . . . 57

3.2 Objetivos $\ldots \ldots \ldots \ldots \ldots \ldots$

3.2 .1 Geral . . . . . . . . . . . . . . . . . . . . . . . 60

3.2.2 Específicos . . . . . . . . . . . . . . . . . . . . . . 60

3.3 SAXS no Laboratório Nacional de Luz Síncrotron (LNLS) . . . . . . . . . . 61

3.4 Representação de Kratky . . . . . . . . . . . . . . . . . . . . . . . . . . . . . 61

3.5 Análises modelo-dependentes . . . . . . . . . . . . . . . . . . . . . . . . . . . . . . . . . . . . . . . . . . 62

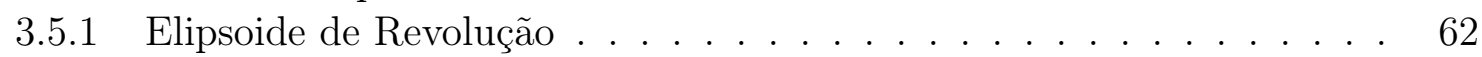

3.5.2 Colar de pérolas . . . . . . . . . . . . . . . . . . . . . . . . . 64

3.6 Amostras $\ldots \ldots \ldots \ldots \ldots$. . . . . . . . . . . . . . . . . . . . . 64

3.7 Resultados e Discussão: BSA na presença de uréia . . . . . . . . . . . . . . . 65 
3.8 Resultados e Discussão: BSA na presença de SDS . . . . . . . . . . . . . . . . . 69

3.9 Resultados e Discussão: BSA na presença de uréia e SDS . . . . . . . . . . . . . 81

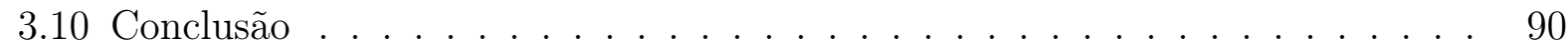

4 Estudo da interação das proteínas globulares albumina de soro bovina

$\begin{array}{ll}\text { (BSA) e lisozima } & 91\end{array}$

4.1 Introdução . . . . . . . . . . . . . . . . . . . . . . . . . . . . . . . . . 91

4.2 Objetivos $\ldots \ldots \ldots \ldots \ldots \ldots \ldots$

4.2 .1 Geral . . . . . . . . . . . . . . . . . . . . . . . . . . . . . . . . 94

$4.2 .2 \quad$ Específico . . . . . . . . . . . . . . . . . . . . . . . . . . 94

4.3 SAXS no Laboratório Nacional de Luz Síncrotron (LNLS) . . . . . . . . . . 94

4.4 Raio de giro . . . . . . . . . . . . . . . . . . . . . . . . 95

4.4 .1 Função distribuição de distâncias . . . . . . . . . . . . . . . . 96

4.5 Sistemas Interagentes ． . . . . . . . . . . . . . . . . . . . . . . . 98

4.6 Amostras $\ldots \ldots \ldots \ldots$. . . . . . . . . . . . . . . . . . . . . . . . . . . . . . . . 101

4.7 Resultados e Discussão $\ldots \ldots \ldots \ldots$. . . . . . . . . . . . . . . . . . . . 102

4.8 Análise Inicial . . . . . . . . . . . . . . . . . . . . . . . . . . . . . . . . . . . . . . . . . 105

4.9 Análise considerando um potencial de interação inter-proteinas . . . . . . . . 109

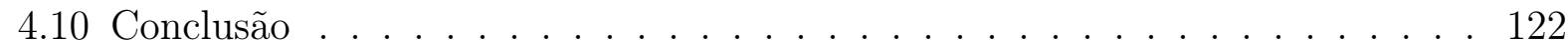

$\begin{array}{lll}5 & \text { Considerações Finais } & 123\end{array}$

\begin{tabular}{ll}
\hline Referências & 126
\end{tabular}

A Análise das amostas contendo BSA e lisozima utilizando o modelo de elipsoide 135

A.1 Combinação dos modelos de agregados elipsoides com as estruturas cristalográficas da BSA e lisozima . . . . . . . . . . . . . . . . . . . 135

\begin{tabular}{ll}
\hline Anexos & 140
\end{tabular}

\begin{tabular}{llr}
\hline I & Publicações & 141
\end{tabular} 


\section{Lista de Figuras}

1.1 Esquema da estrutura das septinas. Figura adaptada da referência [5]. . . . . 4

1.2 Tabela de monômeros de septinas depositadas no PDB. Figura extraída da referência $[9] . \ldots \ldots \ldots \ldots \ldots \ldots \ldots$

1.3 Representação de três monômeros da SEPT2, com as interfaces dímero-G e dímero-NC indicadas. As linhas tracejadas representam regiões desordenadas. Figura extraída da referência $[2] . \ldots \ldots \ldots$

1.4 Estrutura do filamento de SEPT2-SEPT6-SEPT7. A SEPT2, SEPT6 e SEPT7 estão representadadas nas cores vermelha, azul e amarelo, respectivamente. Figura extraída da referência $[9] . \ldots \ldots \ldots$. . . . . . . . . . . 6

1.5 Evolução temporal das curvas de SAXS para a SEPT6G a $(\mathrm{A}) \mathrm{T}=13^{\circ} \mathrm{C}$, (B) $\mathrm{T}=25^{\circ} \mathrm{C},(\mathrm{C}) \mathrm{T}=37^{\circ} \mathrm{C}$ e $(\mathrm{D}) \mathrm{T}=45^{\circ} \mathrm{C}$. Para efeito comparativo, a linha contínua nos gráficos indica o fator de forma $\mathrm{P}(\mathrm{q})$ correspondente ao espalhamento do dímero da SEPT2G. . . . . . . . . . . . . . . . . . . . . . 14

1.6 Evolução temporal das curvas de SAXS para o heterodímero SEPT2G-SEPT6 a (A) $\mathrm{T}=10^{\circ} \mathrm{C},(\mathrm{B}) \mathrm{T}=15^{\circ} \mathrm{C},(\mathrm{C}) \mathrm{T}=25^{\circ} \mathrm{C},(\mathrm{D}) \mathrm{T}=37^{\circ} \mathrm{C}$ e $(\mathrm{E}) \mathrm{T}=45^{\circ} \mathrm{C}$. Para efeito comparativo, a linha contínua nos gráficos indica indica o fator de forma P(q) correspondente ao espalhamento do dímero da SEPT2G. . . . . . 16

1.7 Evolução temporal das curvas de SAXS para o heterodímero SEPT2G-SEPT6G a (A) $\mathrm{T}=55^{\circ} \mathrm{C},(\mathrm{B}) \mathrm{T}=60^{\circ} \mathrm{C},(\mathrm{C}) \mathrm{T}=62^{\circ} \mathrm{C}$ e (D) $\mathrm{T}=65^{\circ} \mathrm{C}$. Para efeito comparativo, a linha contínua nos gráficos indica o fator de forma $\mathrm{P}(\mathrm{q})$ correspondente ao espalhamento do dímero da SEPT2G. $\ldots . . . . . . .17$

1.8 Exemplo de ajuste da curva de SAXS resultante para a SEPT2G-SEPT6G a $\mathrm{T}=55{ }^{\circ} \mathrm{C}$ e t $=380 \mathrm{~s}$, utilizando os modelos de dímero, agregado do tipo cilindro e do tipo Porod, com contribuições de $61 \%, 5 \%$ e $34 \%$, respectivamente (Tabela 1.3). . . . . . . . . . . . . . . . . . . . . . . 19

1.9 Evolução temporal e ajustes das curvas de SAXS para a SEPT6G a (A) T= $13^{\circ} \mathrm{C},(\mathrm{B}) \mathrm{T}=25^{\circ} \mathrm{C},(\mathrm{C}) \mathrm{T}=37^{\circ} \mathrm{C}$ e (D) $\mathrm{T}=45^{\circ} \mathrm{C}$. As linhas contínuas indicam os melhores ajustes obtidos para cada conjunto de dados. . . . . . . . . . . . 21

1.10 Evolução temporal e ajustes das curvas de SAXS para o heterodímero SEPT2GSEPT6G a $(\mathrm{A}) \mathrm{T}=10^{\circ} \mathrm{C}$ a $\mathrm{T}=45^{\circ} \mathrm{C},(\mathrm{B}) \mathrm{T}=55^{\circ} \mathrm{C},(\mathrm{C}) \mathrm{T}=60^{\circ} \mathrm{C}$ e $\mathrm{T}=62^{\circ} \mathrm{C}$ e (D) $\mathrm{T}=65^{\circ} \mathrm{C}$. As linhas contínuas indicam os melhores ajustes obtidos para cada conjunto de dados. . . . . . . . . . . . . . . . . . 25

1.11 Comparação das porcentagens de monômero, dímero, cilindro e agregados grandes do tipo Porod em solução para as septinas SEPT2G, SEPT6G e SEPT2G-SEPT6G. . . . . . . . . . . . . . . . . . . . . . 29

2.1 Representação do dímero da A5[26]. Imagem gerada utilizando o NGL Viewer[28],

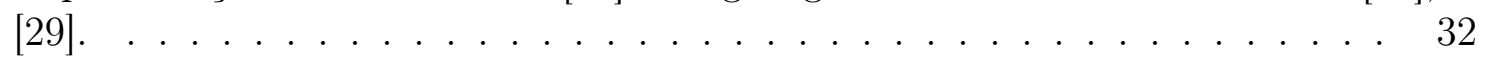


2.2 Estrutura cristalográfica do trímero da A5. I, II, III e IV indicam os 4 dominios do momomero de A5. Imagem extraída da referência|30]. . . . . . . . . 33

2.3 Estrutura cristalográfica do hexâmero da anexina XII, composta por dois trímeros paralelos. Imagem extraída da referência|33]. $\ldots . . . . . .33$

2.4 Representação esquemática do modelo de membrana. Figura extraída da

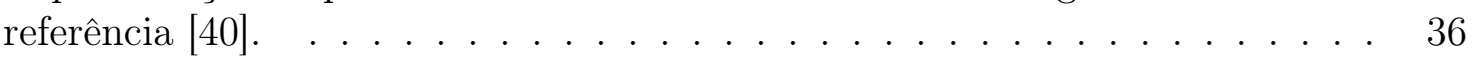

$2.5 \quad$ Estrutura química do lipídio DPPC. Imagem extraída da referência [42]. . . 38

$2.6 \quad$ Estrutura química do lipídio DPPS. Imagem extraída da referência [43]. . . 38

2.7 Comparação das curvas de SAXS (em escala linear) para os lipossomos compostos por: (A) DPPC, DPPC na presença de cálcio; (B) DPPC:DPPS (9:1), DPPC:DPPS (9:1) na presença de cálcio e (C) DPPC:DPPS (9:1) e DPPC. $\quad 41$

2.8 Comparação das curvas de SAXS (em escala log x log) para os lipossomos compostos por: (A) DPPC, DPPC na presença de cálcio; (B) DPPC:DPPS (9:1), DPPC:DPPS (9:1) na presença de cálcio e (C) DPPC:DPPS (9:1) e

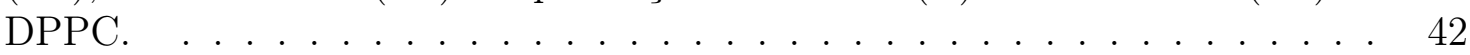

2.9 (A) Curvas de SAXS (em escala linear) para os proteolipossomos de A5 compostos por DPPC + A5, DPPC:DPPS (9:1) + A5, DPPC + A5 na presença de cálcio, DPPC:DPPS (9:1) + A5 na presença de cálcio. (B) Comparação das curvas de SAXS da curva média de todos os proteolipossomos contendo A5 com a curva do lipossomo de DPPC. . . . . . . . . . . . . . . . . . . 44

2.10 (A) Curvas de SAXS (em escala log x log) para os proteolipossomos de A5 compostos por DPPC + A5, DPPC:DPPS $(9: 1)+$ A5, DPPC + A5 na presença de cálcio, DPPC:DPPS (9:1) + A5 na presença de cálcio. (B) Comparação das curvas de SAXS da curva média de todos os proteolipossomos contendo A5 com a curva do lipossomo de DPPC. . . . . . . . . . . . . . . . 45

2.11 (A) Curvas de SAXS (em escala linear) para os proteolipossomos contendo TNAP + A5 compostos por DPPC + A5 + TNAP, DPPC:DPPS (9:1) + A5 + TNAP, DPPC + A5 + TNAP na presença de cálcio, DPPC:DPPS (9:1) + A5 + TNAP na presença de cálcio. (B) Comparação das curvas de SAXS da curva média de todos os proteolipossomos de TNAP + A5 com a curva média de todos os proteolipossomos de A5. . . . . . . . . . . . . . . . 47

2.12 (A) Curvas de SAXS (em escala log x log) para os proteolipossomos contendo TNAP + A5 compostos por DPPC + A5 + TNAP, DPPC:DPPS (9:1) + A5 + TNAP, DPPC + A5 + TNAP na presença de cálcio, DPPC:DPPS (9:1) + A5 + TNAP na presença de cálcio. (B) Comparação das curvas de SAXS da curva média de todos os proteolipossomos de TNAP + A5 com a curva média de todos os proteolipossomos de A5. . . . . . . . . . . . . . . . . 48 
2.13 Exemplo de ajuste da curva de SAXS para o lipossomo de DPPC:DPPS (9:1) na presença de cálcio, utilizando os modelos de bicamada lipídica unilamelar e multilamelar, com contribuições de $88,6 \%$ e 11,4\%, respectivamente (Tabela

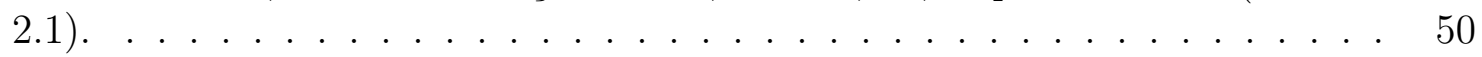

2.14 Melhores ajustes das curvas de SAXS para os lipossomos compostos por: (A) DPPC; (B) DPPC:DPPS (9:1) na presença de cálcio (C) DPPC:DPPS (9:1). 51

2.15 Melhor ajuste da curva média de SAXS para os proteolipossomos de A5 (curva média de DPPC + A5, DPPC:DPPS (9:1) + A5, DPPC + A5 na presença de cálcio, DPPC:DPPS (9:1) + A5 na presença de cálcio, DPPC + A5 + TNAP, DPPC:DPPS (9:1) + A5 + TNAP, DPPC + A5 + TNAP na presença de cálcio e DPPC:DPPS (9:1) + A5 + TNAP na presença de cálcio). . . . . . . 52

2.16 Comparação do perfil de densidade eletrônica para os lipossomos com relação aos proteolipossomos de A5 e A5 + TNAP. . . . . . . . . . . . . . . 54

3.1 Estrutura cristalográfica da BSA [52]. Imagem gerada utilizzando o NGL

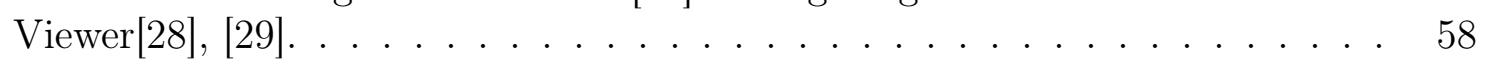

3.2 Estrutura química do SDS. Imagem extraída da referência [54]. . . . . . . . . 58

3.3 Estrutura química da uréia. Imagem extraída da referência [58].] . . . . . . . 59

3.4 Representação esquemática do elipsoide prolato de revolução com dois níveis de densidade eletrônica diferentes em relação ao solvente $\left(\rho_{0}\right)$ utilizada para

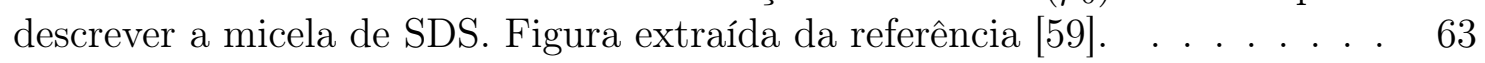

3.5 Representação esquemática do modelo de colar de pérolas. Figura extraída da referência [61]. . . . . . . . . . . . . . . . . . . . . . . . . . . . . 64

3.6 Curvas de SAXS para BSA a $\mathrm{T}=23^{\circ} \mathrm{C}, \mathrm{pH} 7.0$, na ausência e presença de 3 M e 8 M de uréia. O destaque na Figura mostra a representação de Kratky para as mesmas curvas, evidenciando o desenovelamento total da proteína a $8 \mathrm{M}$ de uréia . . . . . . . . . . . . . . . . . . 65

3.7 Curvas de SAXS para BSA, pH 7.0, a temperatura variável de $23^{\circ} \mathrm{C}$ a $50^{\circ} \mathrm{C}$, (A1) na ausência de uréia, na presença de (B1) $3 \mathrm{M}$ e (C1) $8 \mathrm{M}$ de uréia. Os destaques nas Figuras mostram as representações de Kratky para as mesmas

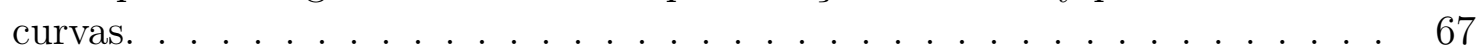

3.8 Curvas de SAXS (escala log x log) para BSA, $\mathrm{pH} 7.0$, a temperatura variável de $23^{\circ} \mathrm{C}$ a $30^{\circ} \mathrm{C}$, (A) na ausência de uréia, na presença de (B) $3 \mathrm{M}$ e (C) $8 \mathrm{M}$ de uréia. . . . . . . . . . . . . . . . . . . . . . 68

3.9 Curvas de SAXS para BSA a $\mathrm{T}=23^{\circ} \mathrm{C}$, pH 7.0, com SDS em concentração variável de 0 a $80 \mathrm{mM}$. O destaque na Figura mostra a representação de Kratky para as mesmas curvas. . . . . . . . . . . . . . . . . . . 70

3.10 Melhor ajuste da curva de SAXS para BSA a $\mathrm{T}=23^{\circ} \mathrm{C}$, pH 7.0, com SDS em concentração igual a $30 \mathrm{mM}$, utilizando os modelos da estrutura cristalográfica da proteína e micela (elipsoide). . . . . . . . . . . . . . . . . 72 
3.11 Melhor ajuste da curva de SAXS para BSA a T $=23^{\circ} \mathrm{C}, \mathrm{pH} 7.0$, com SDS em concentração igual a $50 \mathrm{mM}$, utilizando os modelos da estrutura cristalográfica da proteína e micelas livres em solução. . . . . . . . . . . . . . . . . . . . . . 74

3.12 Melhor ajuste da curva de SAXS para BSA a $\mathrm{T}=23^{\circ} \mathrm{C}, \mathrm{pH} 7.0$, com SDS em concentração igual a $50 \mathrm{mM}$, utilizando os modelos da estrutura cristalográfica da proteína e "colar de pérolas". . . . . . . . . . . . . . . . . . . . 75

3.13 Curvas de SAXS para BSA, pH 7.0, a temperatura variável de $23^{\circ} \mathrm{C}$ a $50^{\circ} \mathrm{C}$, com SDS em concentração igual a (A) 1 mM, (B) 3 mM, (C) $6 \mathrm{~m} \mathrm{M} \mathrm{e} \mathrm{(D)} 10$ mM. Os destaques nas Figuras mostram as representações de Kratky para as mesmas curvas. . . . . . . . . . . . . . . . . . . 77

3.14 Ampliação da região de $q$ pequenos das curvas de SAXS para BSA, pH 7.0, a temperatura variável de $23^{\circ} \mathrm{C}$ a $50^{\circ} \mathrm{C}$, com SDS em concentração igual a (A)

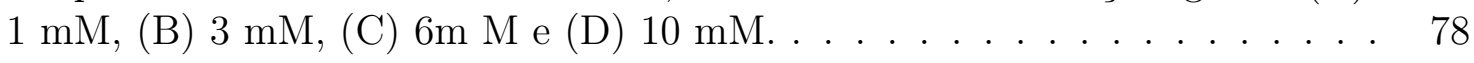

3.15 Curvas de SAXS para BSA, pH 7.0, a temperatura variável de $23^{\circ} \mathrm{C}$ a $50^{\circ} \mathrm{C}$, com SDS a 30 mM. (A) Gráfico em escala linear, com destaque mostrando as representações de Kratky para as mesmas curvas. (B) Ampliação do gráfico em escala logarítmica para ressaltar o deslocamento do mínimo da micela. . . 80

3.16 Curvas de SAXS para BSA a $\mathrm{T}=23^{\circ} \mathrm{C}, \mathrm{pH} 7.0$, na presença de $3 \mathrm{M}$ de uréia e concentração variável de 0 a $30 \mathrm{mM}$ de SDS. O destaque na Figura mostra a representação de Kratky para as mesmas curvas. . . . . . . . . . . . . . . 81

3.17 Curvas de SAXS para BSA a $\mathrm{T}=23^{\circ} \mathrm{C}$, $\mathrm{pH} 7.0$, na ausência e presença de 3 M uréia e SDS em concentração igual a (A) $1 \mathrm{mM}$, (B) $6 \mathrm{mM}$, (C) $10 \mathrm{mM}$ e (D) 30 mM. Os destaques nas Figuras mostram a representação de Kratky para as mesmas curvas. . . . . . . . . . . . . . . . . . 82

3.18 Melhores ajustes das curvas de SAXS para BSA a $\mathrm{T}=23^{\circ} \mathrm{C}, \mathrm{pH} 7.0$, com $3 \mathrm{M}$ de uréia e concentração variável de SDS, utilizando os modelos da estrutura cristalográfica da proteína e "colar de pérolas". . . . . . . . . . . . . . . . . 83

3.19 Melhores ajustes das curvas de SAXS para BSA a $\mathrm{T}=23^{\circ} \mathrm{C}, \mathrm{pH} 7.0$, com $3 \mathrm{M}$ de uréia e concentração variável de SDS, utilizando os modelos da estrutura cristalográfica da proteína e "colar de pérolas". . . . . . . . . . . . . . . . 85

3.20 Curvas de SAXS para BSA, pH 7.0, a temperatura variável de $23^{\circ} \mathrm{C}$ a $50^{\circ} \mathrm{C}$, na presença de 3M de uréia e SDS em concentração igual a (A) 1 mM, (B) 6mM, (C) $10 \mathrm{mM}$ e (D) $30 \mathrm{mM}$. Os destaques nas Figuras mostram as representações de Kratky para as mesmas curvas. . . . . . . . . . . . . . . . . . . . 88

3.21 Ampliação na região de q pequenos das curvas de SAXS para BSA, $\mathrm{pH} 7.0$, a temperatura variável de $23^{\circ} \mathrm{C}$ a $50^{\circ} \mathrm{C}$, na presença de $3 \mathrm{M}$ de uréia e SDS em concentração igual a (A) 1 mM, (B) $6 \mathrm{mM}$, (C) $10 \mathrm{mM}$ e (D) $30 \mathrm{mM} . \quad$. . . . $\quad 89$

4.1 Estrutura cristalográfica da lisozima. Imagem gerada utilizando o NGL Viewer[28],

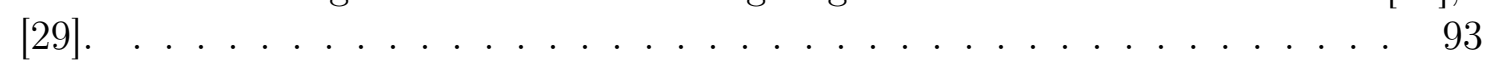


4.2 Intensidades de espalhamento e funções distribuição de distâncias $p(r)$ de diferentes corpos geométricos. Figura extraída da referência [68].

4.3 Curvas de SAXS para BSA e Lisozima a $\mathrm{T}=23^{\circ} \mathrm{C}, \mathrm{pH} 7.0$, variando-se a razão molar BSA:lisozima, conforme especificado na legenda. . . . . . . . . . . . . 103

4.4 Curvas de SAXS para BSA e Lisozima a $\mathrm{T}=23^{\circ} \mathrm{C}, \mathrm{pH} 7.0$. (A) $100 \%$ de BSA e BSA:LISO de 1:0,5 até 1:5. A linha contínua vermelha indica o fator de forma $\mathrm{P}(\mathrm{q})$ da BSA obtido a parir da estrutura cristalográfica da BSA (código pdb 4F5S); (B) 100\% de lisozima e BSA:LISO de 1:5 até 1:42. A linha contínua cinza indica o fator de forma $\mathrm{P}(\mathrm{q})$ da lisozima obtido a parir da estrutura cristalográfica da lisozima (código pdb 2CDS). . . . . . . . . . . . . . . . . . 104

4.5 Raio de giro em função do número de monômeros de lisozima para cada monômero da BSA. . . . . . . . . . . . . . . . . . . . . 106

4.6 Intensidade de espalhamento em $q \rightarrow 0$, I(0), em função do número de monômeros de lisozima para cada monômero da BSA. . . . . . . . . . . . . . . . . 107

4.7 Funções distribuições de distâncias, $\mathrm{p}(\mathrm{r})$, para BSA:LISO 1:0,5 a BSA:LISO $1: 42,100 \%$ BSA e $100 \%$ lisozima. . . . . . . . . . . . . . . 107

4.8 Funções distribuições de distâncias, p(r), (A) 100\% de BSA e BSA:LISO de 1:0,5 até 1:5; (B) 100\% de lisozima e BSA:LISO de 1:5 até 1:42. $\ldots$. . . . . . 108

4.9 Melhores ajustes das curvas de SAXS para (A) BSA $100 \mathrm{mg} / \mathrm{mL}$ e (B) lisozima $100 \mathrm{mg} / \mathrm{mL}$ a $\mathrm{T}=23^{\circ} \mathrm{C}, \mathrm{pH}$ 7.0. $\ldots \ldots \ldots \ldots . \ldots . \ldots 112$

4.10 Influência do fator de acoplamento $\beta(q)$ na função de interferência $S_{e q}(q)$ utilizada no ajuste da curva de SAXS (A) BSA $100 \mathrm{mg} / \mathrm{mL}$ e (B) lisozima $100 \mathrm{mg} / \mathrm{mL}$ a $\mathrm{T}=23^{\circ} \mathrm{C}, \mathrm{pH}$ 7.0. $\ldots \ldots \ldots \ldots . . \ldots . . \ldots 113$

4.11 Exemplo de ajuste da curva de SAXS para proporção de monômeros BSA:LISO $1: 7 . \ldots \ldots \ldots 114$

4.12 Exemplo da influência do fator de acoplamento $\beta(q)$ na função de interferência $S_{e q}(q)$ utilizada no ajuste da curva de SAXS para proporção de monômeros BSA:LISO 1:7. . . . . . . . . . . . . . . . . . . . . . . 114

4.13 Melhores ajustes das curvas de SAXS para BSA e Lisozima a $\mathrm{T}=23^{\circ} \mathrm{C}, \mathrm{pH}$ 7.0 com (A) BSA:LISO 1:0,5; (B) BSA:LISO 1:1,2 e (C) BSA:LISO 1:2. . . . 115

4.14 Melhores ajustes das curvas de SAXS para BSA e Lisozima a $\mathrm{T}=23^{\circ} \mathrm{C}, \mathrm{pH}$ 7.0 com (A) BSA:LISO 1:3; (B) BSA:LISO 1:5 e (C) BSA:LISO 1:7. . . . . . 116

4.15 Melhores ajustes das curvas de SAXS para BSA e Lisozima a $\mathrm{T}=23^{\circ} \mathrm{C}, \mathrm{pH}$ 7.0 com (A) BSA:LISO 1:11; (B) BSA:LISO 1:19 e (C) BSA:LISO 1:42. . . . 117

4.16 Funções de interferência $S_{e q}(q)$, para BSA:LISO 1:0,5 a BSA:LISO 1:42. . . . 118

4.17 Funções de interferência $S_{e q}(q)$, para (A) BSA:LISO 1:0,5 a BSA:LISO 1:2 e (B) BSA:LISO 1:3 a BSA:LISO 1:42. $\ldots \ldots \ldots$. . . . . . . . . . . 119

4.18 Potenciais para BSA:LISO 1:0,5 a BSA:LISO 1:42, 100\% BSA e 100\% lisozima. . . . . . . . . . . . . . . . . . . . 120 
4.19 Potenciais para (A)100\% BSA, BSA:LISO 1:0,5 a BSA:LISO 1:2 e (B) BSA:LISO 1:3 a BSA:LISO 1:42 e 100\% lisozima. . . . . . . . . . . . . . . . 121

A.1 Melhores ajustes das curvas de SAXS para BSA e Lisozima a $\mathrm{T}=23^{\circ} \mathrm{C}$, pH 7.0 com (A) BSA:LISO 1:0,5; (B) BSA:LISO 1:1,2 e (C) BSA:LISO 1:2. . . . 137

A.2 Melhores ajustes das curvas de SAXS para BSA e Lisozima a $\mathrm{T}=23^{\circ} \mathrm{C}, \mathrm{pH}$ 7.0 com (A) BSA:LISO 1:3; (B) BSA:LISO 1:5 e (C) BSA:LISO 1:7. . . . . . 138

A.3 Melhores ajustes das curvas de SAXS para BSA e Lisozima a $\mathrm{T}=23^{\circ} \mathrm{C}$, pH 7.0 com (A) BSA:LISO 1:11; (B) BSA:LISO 1:19 e (C) BSA:LISO 1:42. . . . 139 


\section{Lista de Tabelas}

1.1 Porcentagens dos modelos de monômero, dímero, cilindro e agregado do tipo Porod nos ajustes experimentais para SEPT6G (conforme descritos na Seção

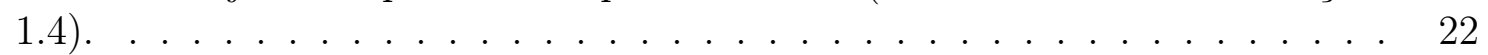

1.2 Parâmetros dos ajustes experimentais para SEPT6G (conforme descritos na

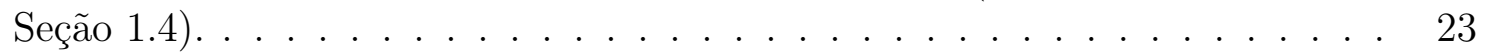

1.3 Porcentagens dos modelos de dímero, cilindro e agregado do tipo Porod nos ajustes experimentais para SEPT2G-SEPT6G (conforme descritos na Seção

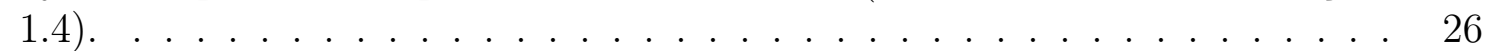

1.4 Parâmetros dos ajustes experimentais para SEPT2G-SEPT6G (conforme des-

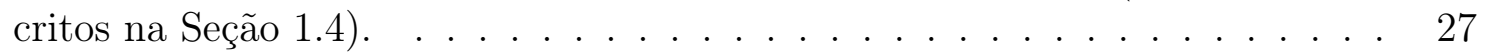

2.1 Parâmetros dos ajustes experimentais (item 2.3 .1$)$ para lipossomos e proteolipossomos estudados. . . . . . . . . . . . . . . . 53

3.1 Parâmetros dos ajustes experimentais para as amostras de BSA com $30 \mathrm{mM}$ e $50 \mathrm{mM}$ de SDS. . . . . . . . . . . . . . . . . . . . 73

3.2 Parâmetros dos ajustes experimentais para as amostras de BSA, SDS e 3 M de Uréia. . . . . . . . . . . . . . . . . . . . . . . . 84

3.3 Parâmetros dos ajustes experimentais para as amostras de BSA, SDS e 8M de Uréia. . . . . . . . . . . . . . . . . . . . . 86

4.1 Composição das amostras de BSA e lisozima. . . . . . . . . . . . . . . . . . . 101

4.2 Parâmetros dos ajustes experimentais para as amostras de BSA e lisozima. São eles: densidade eletrônica relativa da camada de hidratação do modelo da estrutura cristalográfica com relação ao solvente, $d_{c o r}$; profundidade do potencial $J$; alcance do potencial atrativo, $d$; módulo da carga efetiva da proteína em solução $|Z|$; diâmetro efetivo da esfera dura $\sigma_{\text {ef }}$ e raio $R$ e comprimento $L$

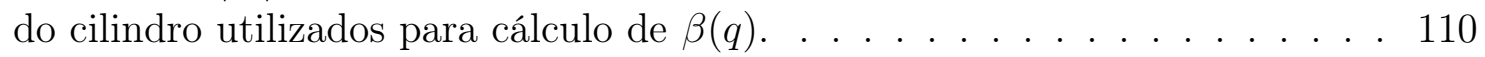





\section{Resumo}

Neste trabalho estudamos por espalhamento de raios-X a baixos ângulos (SAXS) quatro diferentes sistemas de interesse biológico. Visamos investigar a auto-agregação de proteínas e de complexos proteicos que darão origem a fibras amilóides, interação proteína-proteína, simulando ambientes altamente concentrados, interação proteína-membrana simulando vesículas de matriz extracelular (MVs) de sistemas de biomineralização e interações proteínaagentes desnaturantes.

No caso de formação de amilóides, investigamos a agregação do domínio GTPase da septina 6 (SEPT6G) e do complexo formado com o domínio GTPase da septina 2 (SEPT2GSEPT6G). A temperaturas de até $15^{\circ} \mathrm{C}$, tanto SEPT6G quanto SEPT2G-SEPT6G apresentam-se predominantemente diméricas em solução. Já a $25^{\circ} \mathrm{C}$, o heterodímero SEPT2GSEPT6G permanece estável enquanto agregados maiores de SEPT6G evoluem e coexistem em solução com SEPT6G-SEPT6G dimérica, sendo que a proporção de dímeros diminui com a temperatura.

No estudo das MVs, mostramos que miméticos lipossomais de DPPC e DPPC:DPPS (9:1) possuem as mesmas características estruturais na ausência e presença de cálcio na solução. A interação da proteína anexina $\mathrm{V}$ humana (A5), envolvida em processos de biomineralização, impacta na membrana modelo induzindo a formação de nanoporos. A adição da fosfatase alcalina tecido não-específico (TNAP) não altera as propriedades estruturais do proteolipossomo na presença de A5.

A ação do surfactante dodecil sulfato de sódio (SDS) a 30 mM não altera a conformação da albumina soro bovina (BSA), de maneira que é observada a formação de micelas de SDS coexistindo com a proteína livre em solução. Já a adição de $50 \mathrm{mM}$ de SDS induz um desenovelamento parcial da proteína, identificado pela análise das curvas de SAXS via modelo de "colar de pérolas". A ação de uréia a $3 \mathrm{M}$ e $8 \mathrm{M}$ promove um desenovelamento parcial e total da BSA, respectivamente, com subsequente agregação de proteína dependente da temperatura $\left(\mathrm{T}>30^{\circ} \mathrm{C}\right)$. A adição de $6 \mathrm{mM}$ de SDS em proteínas parcialmente desenoveladas pela ação da uréia promove um desenovelamento mais acentuado.

O potencial efetivo resultante da interação entre duas proteínas distintas, BSA e lisozima a concentração total de $100 \mathrm{mg} / \mathrm{mL}$ em solução, $\mathrm{pH}$ 7.0, foi obtido da análise de curvas de SAXS. Para isto, utilizou-se uma análise simplificada (em primeira aproximação) considerando um potencial efetivo de interação entre BSA-BSA, lisozima-lisozima e lisozima-BSA. Variamos a razão molar BSA:LISO até 1:42. No pH estudado, BSA tem uma carga residual superficial de $-11 e$, enquanto a lisozima possui $+9 e$. Conforme variamos a razão molar BSA:LISO, observamos dois regimes para o potencial efetivo resultante: i) até BSA:LISO $1: 2$, a carga efetiva do sistema é praticamente nula com um potencial resultante de caráter atrativo e ii) para razões entre BSA:LISO 1:3 a 1:42, a carga efetiva aumenta e o potencial resultante tem caráter repulsivo. Assim, lisozima e BSA coexistem sem agregar, através de um delicado balanço de forças atrativas e repulsivas no sistema. 



\section{Abstract}

In this work we have used small-angle x-ray scattering (SAXS) to study four systems of biological interest. We aim to investigate the self aggregation of proteins and protein complexes that would form amyloid fibers; protein/protein interaction, simulating high concentrations; protein/cell-membrane interaction, simulating extracellular matrix vesicles (MVs) from biomineralizing systems; and protein/denaturating-agents interactions.

On the case of amyloid formation, we have investigated the aggregation of G-domain of septin-6 (SEPT6G) and the protein complex formed with G-domain of septin-2 (SEPT2GSEPT6G). At temperatures lower than $15^{\circ} \mathrm{C}$, both SEPT6G and SEPT2G-SEPT6G were found predominantly as dimers. At $25^{\circ} \mathrm{C}$, SEPT2G-SEPT6G heterodimer is still stable while aggregates of SEPT6G grow. Both coexist in solutions of SEPT2G-SEPT6G dimers, with the percentage of dimers decreasing the higher the temperature.

As for the study of MVs, we have shown that DPPC and DPPC:DPPS (9:1) liposomal mimetics have the same structural characteristics at the absence or presence of Calcium. The interaction with human annexin $\mathrm{V}$ protein (A5), related to biomineralization processes, affects the model membrane by the creation of nanopores. The addition of tissue-nonspecific alkaline phosphatase (TNAP) does not change the structural properties of the proteoliposome when A5 is present.

The addition of SDS surfactant $(30 \mathrm{mM})$ does not alters the conformation of bovine serum albumin (BSA), and we have observed the formation of SDS micelles coexisting with free protein in solution. The addition of $50 \mathrm{mM}$ of SDS, on the other hand, induces the partial unraveling of the protein, as seen by the analysis of SAXS data via the "pearl necklace" model. The effect of adding $3 \mathrm{M}$ and $8 \mathrm{M}$ urea is, respectively, the partial and total unraveling of BSA, with ensuing aggregation of the protein dependent on the temperature $\left(T>30^{\circ} \mathrm{C}\right)$. The introduction of SDS $6 \mathrm{mM}$ promotes further unraveling in proteins that were previously partially unraveled by urea.

The resulting effective potential for the interaction between BSA and lysozyme at total concentration of $100 \mathrm{mg} / \mathrm{ml}$ and $7.0 \mathrm{pH}$ has been obtained from the analysis of SAXS curves. In order to obtain this result we have used a simplified analysis (first order approximation) in which were considered the effective potentials for the interactions between BSA-BSA, lysozyme-lysozyme and lysozyme-BSA. We have varied the BSA:LISO molar ratio up to 1:42. At the studied $\mathrm{pH}, \mathrm{BSA}$ has a surface residual charge of $-11 e$, and lysozyme has +9 e. As we changed the BSA:LISO molar ratio, we have found two regimens for the resulting effective potential: i) up to BSA:LISO 1:2, the effective charge of the system is virtually zero and the resulting potential is attractive; and ii) for BSA:LISO between 1:3 and 1:42 the effective charge increases, and the resulting potential is repulsive. Therefore, both lysozyme and BSA coexist without forming aggregates, by a delicate balance of attractive and repulsive forces. 



\section{Prefácio}

Cristalografia e ressonância magnética nuclear(NMR) são as principais técnicas utilizadas para obter informações de estruturas macromoleculares proteicas. Entretanto, as análises com NMR são restritas a pequenas proteínas e para cristalografia é necessário que a proteína esteja na forma de um cristal. Assim, estas duas técnicas acabam por não serem suficientes para caracterização de muitas proteínas e seus processos de agregação, polimerização e desenovelamento, interação com membranas, entre outros[1].

Por outro lado, a técnica de espalhamento de raios-X a baixos ângulos (SAXS) apresentase como uma ferramenta importante para determinar as características estruturais de macromoléculas em solução. SAXS fornece informações precisas com relação ao tamanho e forma de moléculas isoladas ou interagindo com interfaces, como também informações detalhadas de macromoléculas complexas. Entre os parâmetros possíveis de serem descritos estão o peso molecular, volume, grau de compactação e informações com relação aos processos de agregação.

A técnica de SAXS pode ser aplicada em diversas condições, como por exemplo, com alterações de temperatura, presença de agentes desnaturantes, alterações de concentração, bem como na presença de membranas lipídicas, sendo possível também analisar a evolução temporal destes sistemas. metodologia de análise não é única, mas depende do sistema biologico a ser investigado. Neste contexto, esta tese de doutoramento será focada na aplicação da técnica de SAXS para investigar interação proteina-proteína, proteína-membrana e proteína-agentes desnaturantes, detalhando em cada caso a escolha da metodologia de análise empregada. Assim, cada capítulo descreve um sistema de relevância biologica, cuja importância é apresentada na Introdução do mesmo, seguido de Metodologia de Análises, Resultados e Discussão. 
Neste contexto, no Capítulo 1 avaliamos por SAXS a formação de homooligômeros e heterooligômeros formados pela associação de septina $2 \mathrm{G}$ e septina $6 \mathrm{G}$ em função da temperatura e do tempo de incubação.

No Capítulo 2 são investigadas por SAXS as características estruturais de lipossomos interagindo com anexina $\mathrm{V}$ humana (A5) e fosfatase alcalina tecido não-especifico (TNAP) que possui uma âncora GPI.

No Capítulo 3 serão mostrados os modelos utilizados para o desenvolvimento da metodologia de análise e os resultados do estudo dos efeitos de agentes desnaturantes SDS e uréia na estrutura terciária da proteína albumina de soro bovina (BSA). Neste capítulo mostramos primeiramente os efeitos em separado de cada um dos desnaturantes e, em seguida, os resultados no sistema contendo BSA, uréia e SDS com variação de temperatura e também a evolução temporal.

No Capítulo 4, serão mostrados os modelos utilizados e os resultados provenientes da análise da interação de duas proteínas globulares de pesos moleculares diferentes, a albumina de soro bovina (BSA) e a lisozima. Neste caso, como não existe um modelo teórico na literatura que descreva as correlações proteína-proteína, propomos uma analise simplificada (em primeira aproximação) considerando um potencial efetivo de interação entre BSA-BSA, lisozima-lisozima e lisozima-BSA.

Por fim, no Capítulo 5, constam as conclusões da presente tese e nos Anexos estão os trabalhos publicados no período do doutorado. 


\section{Capítulo 1}

\section{Estudo do processo de agregação da sep- tina 6G (SEPT6G) e heterodímero sep- tina 2G - septina 6G (SEPT2G-SEPT6G)}

\subsection{Introdução}

As septinas fazem parte de uma família de proteínas de ligação ao nucleotídeo guanina que atuam no ciclo de divisão celular e também são amplamente encontradas em doenças neurodegenerativas tais como mal de Parkinson e Alzheimer e em alguns tipos de câncer (assim como leucemia, linfoma e tumores sólidos)[2]. Em mamíferos, são conhecidos 13 tipos de septinas humanas que apresentam estrutura composta por um domínio central GTPase, que contém sequência denominada de "septin unique element"(SUE) composta por 53 aminoácidos que caracteriza as proteínas da família das septinas [3, 4], um domínio N-terminal e um C-terminal. Um esquema de sua estrutura pode ser observado na Figura 1.1) [5]. A estrutura primária dessas proteínas tem entre 40 a 60 kDa. 
Estudo do processo de agregação da septina 6G (SEPT6G) e heterodímero

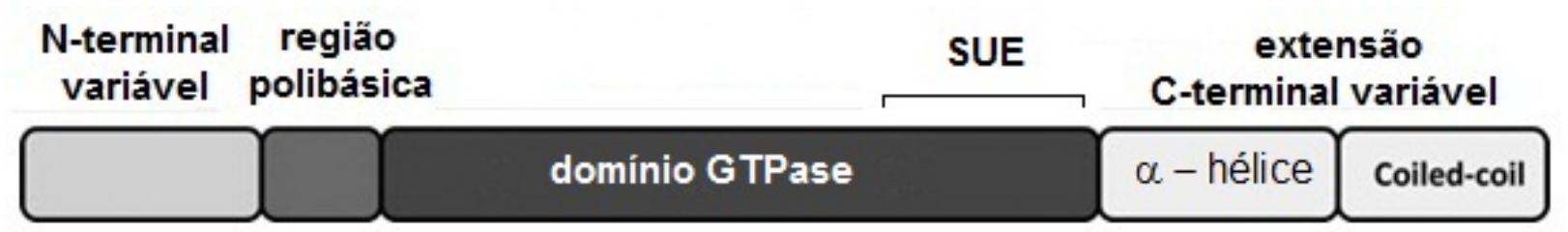

Figura 1.1: Esquema da estrutura das septinas. Figura adaptada da referência [5].

As septinas formam filamentos que têm duas principais funções em células saudáveis [6]: criar uma estrutura temporária para interações entre outras proteínas e seus substratos e compartimentar o citosol e o retículo endoplasmático, servindo de localizador espacial para várias proteínas com funções fundamentais na polarização celular e na progressão do ciclo celular. Podem atuar também na organização de microtúbulos, podendo afetar de maneira crítica a mobilidade celular [7, 8]. A Figura 1.2 mostra uma tabela dos monômeros de septinas para cada estrutura cristalográfica depositada no PDB (Protein Data Bank).

Na Figura 1.3 é mostrada a estrutura cristalográfica da SEPT2 e na Figura 1.4 a estrutura do complexo SEPT2-SEPT6-SEPT7 [2]. Note que no heterodímero, SEPT2-SEPT2 se ligam através da interface NC, enquanto SEPT2-SEPT6 se associam via interface G. Já SEPT6SEPT7 se associam via interface NC. 


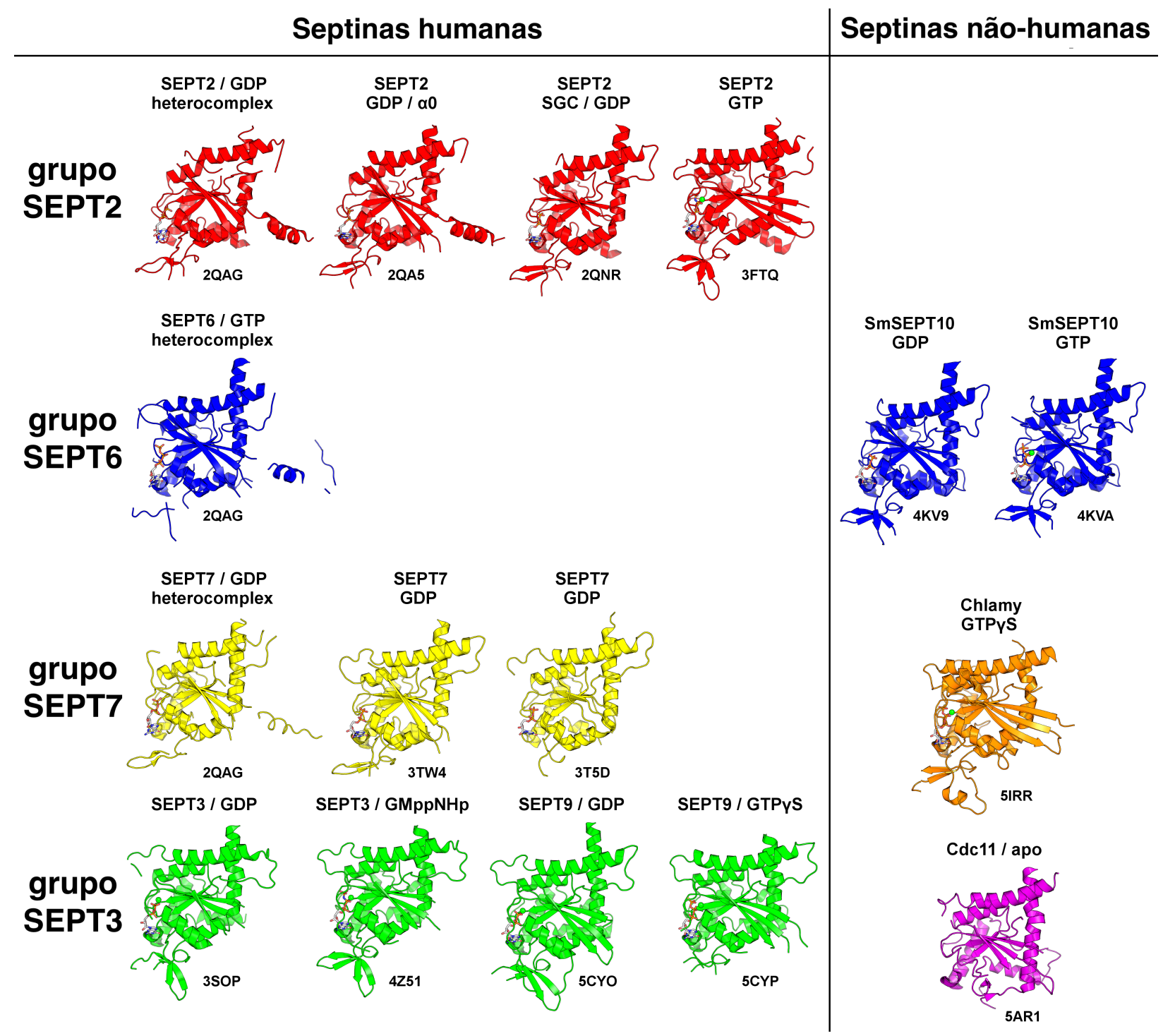

Figura 1.2: Tabela de monômeros de septinas depositadas no PDB. Figura extraída da referência [9]. 


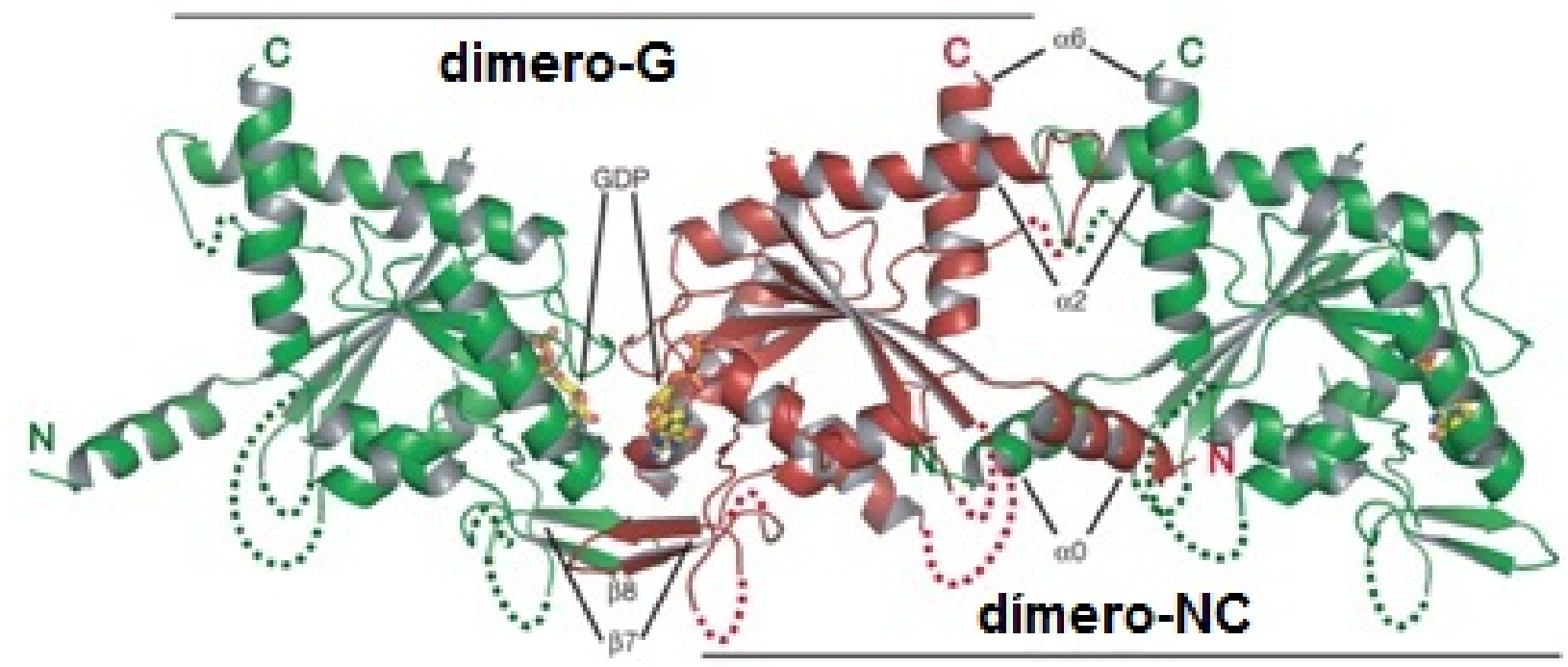

Figura 1.3: Representação de três monômeros da SEPT2, com as interfaces dímero-G e dímero-NC indicadas. As linhas tracejadas representam regiões desordenadas. Figura extraída da referência [2].

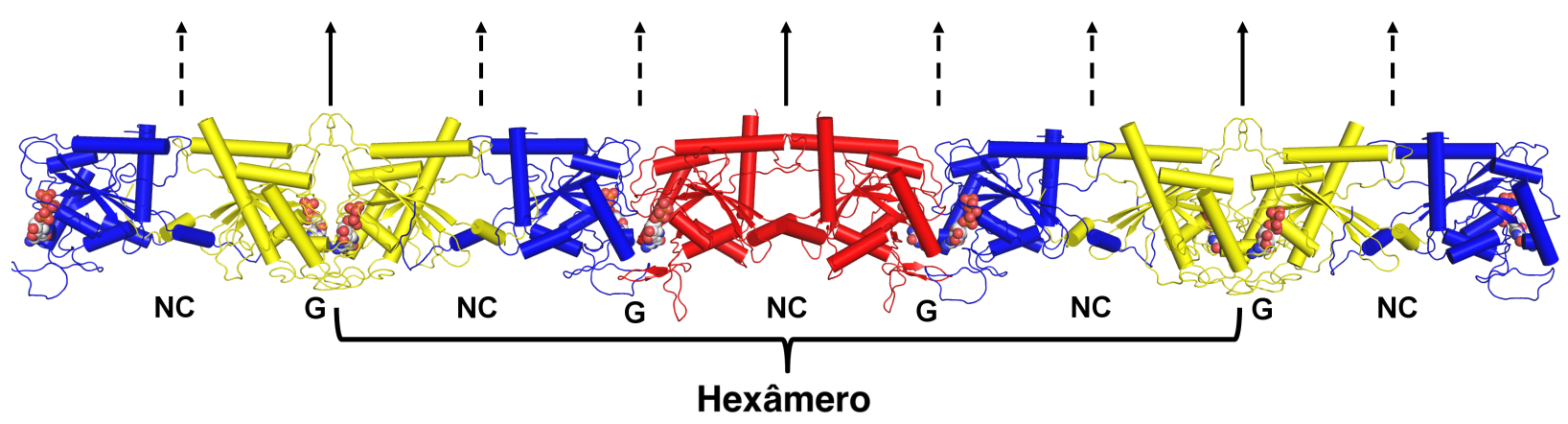

Figura 1.4: Estrutura do filamento de SEPT2-SEPT6-SEPT7. A SEPT2, SEPT6 e SEPT7 estão representadadas nas cores vermelha, azul e amarelo, respectivamente. Figura extraída da referência [9]. 
Análises anteriores realizadas pelo grupo da Profa. Dra. Ana Paula Araújo (IFSC-USP), utilizando a técnica de espectroscopia de fluorescência extrínseca com um marcador conhecido para fibras amilóides chamado Tioflavina- $\mathrm{T}$ (ThT), demonstraram que, a temperaturas maiores que $25^{\circ} \mathrm{C}$ e concentração de cerca de $0,44 \mathrm{mg} / \mathrm{mL}$, as estruturas formadas pela SEPT2 inteira e apenas seu domínio GTPase (SEPT2G) tratavam-se de fibras amilóides [10, 11], sendo que a SEPT2 começa a associar-se como oligômeros a $4^{\circ} \mathrm{C}$ após 48 horas de incubação.

No estudo realizado anteriormente pelo grupo da Profa. Rosangela Itri, resultados de DLS revelaram que a cinética de agregação da proteína é da ordem de segundos para temperaturas maiores que $25^{\circ} \mathrm{C}$. Utilizamos a técnica de espalhamento de raios-X a baixos ângulos para analisar o efeito da concentração, temperatura e evolução temporal da SEPT2G. Os resultados demonstraram uma cinética muito rápida de agregação a temperatura fisiológica, acentuada com o aumento de concentração da proteína em solução[12].

Os dados de SAXS da proteína a $0,5 \mathrm{mg} / \mathrm{ml}$ mostraram que a SEPT2G é um dímero em solução aquosa a $4^{\circ} \mathrm{C}$ e esta configuração se mantém estável por cerca de 1 hora de observação experimental. A $15^{\circ} \mathrm{C}$, os resultados de SAXS revelaram uma coexistência de três populações em solução compostas por $88 \%$ de dímeros, $10 \%$ de agregados pequenos tipocilindros (protofibrilas), e 2\% de agregados grandes maiores que a resolução da técnica. Após cerca de 30 minutos existe um rearranjo preferencial de dímeros em favor de agregados muito grandes cuja contribuição à curva de espalhamento torna-se $8 \%$. A $25^{\circ} \mathrm{C}$, a porcentagem de dímeros decresce para $70 \%$ com uma contribuição de cerca de $30 \%$ de agregados grandes já no início das medidas experimentais. Nas temperaturas de $37{ }^{\circ} \mathrm{C}$ e $45^{\circ} \mathrm{C}$, dímeros e agregados muito grandes coexistem em solução desde o início das medidas experimentais, cujo equilíbrio se desloca rapidamente tal que após 20 minutos de observação a solução é composta majoritariamente por agregados muito grandes, identificados como estruturas amilóides pela técnica de fluorescência da tioflavina, que se intercala em estruturas cross$\beta[12$.

A $1 \mathrm{mg} / \mathrm{mL}$ e temperatura de $4^{\circ} \mathrm{C}$, a proteína permaneceu estável durante cerca de 1 hora de observação sendo que existe um equilíbrio de dímeros (93\%) com agregados alongados (contendo cerca de 80 monômeros) em solução. Com o aumento da temperatura para $15^{\circ} \mathrm{C}$, a maioria da população ainda é dimérica. Já a $25^{\circ} \mathrm{C}$, a presença de agregados muito grandes é bem significativa (da ordem de 30\% coexistindo com dímeros e oligômeros). A $37^{\circ} \mathrm{C}$ e $45^{\circ} \mathrm{C}$ existe a formação de grandes agregados similar ao observado para a SEPT2G 
a $0,5 \mathrm{mg} / \mathrm{mL}[12]$.

Com relação à septina 6G (SEPT6G), estudos estão sendo realizados para avaliar a importância das interfaces no processo de dimerização e formação de heterocomplexos. Em especial, após a construção do heterodímero SEPT2G-SEPT6G, foram estudados tanto a formação de agregados do tipo amilóides por sonda fluorescente Tioflavina- $\mathrm{T}$ (ThT) quanto a estabilidade estrutural térmica utilizando-se espectroscopia de dicroísmo circular[13]. Neste contexto, a técnica de espalhamento de raios-X a baixos ângulos (SAXS) vem a complementar os estudos previamente realizados com outras técnicas experimentais. Utilizando a técnica de SAXS, torna-se possível detalhar os estágios iniciais de formação de dímeros, agregados amorfos e agregados do tipo amilóide.

\subsection{Objetivos}

\section{Geral}

No presente trabalho, temos como objetivo utilizar a técnica de SAXS para analisar o efeito da temperatura, bem como a evolução temporal, dos possíveis estágios de agregação da SEPT6G e do heterodímero SEPT2G-SEPT6G a concentração de 0,4 mg/mL.

\section{Específicos}

- Investigar por SAXS a evolução temporal da formação de oligômeros de SEPT6G com concentração igual a $0,4 \mathrm{mg} / \mathrm{mL}$ a $\mathrm{T}=13,25,37$ e $45^{\circ} \mathrm{C}$;

- Investigar por SAXS a evolução temporal da formação de heterooligômeros de SEPT2GSEPT6G com concentração igual a $0,4 \mathrm{mg} / \mathrm{mL}$ a $\mathrm{T}=10,15,25,37,45,55,60,62$ e $65^{\circ} \mathrm{C}$;

- Comparar a termoestabilidade dos agregados formados por SEPT2G-SEPT6G com os formados pelas septinas SEPT2G e SEPT6G isoladas. 


\subsection{Amostras}

Foram analisadas amostras de SEPT6G e do heterodímero SEPT2G-SEPT6G, a concentração de 0,4 mg/mL, em tampão Tris 25mM, Glicerol 10\% a pH 7,8. A expressão e a purificação das proteínas foram realizadas pelo grupo da Prof. ${ }^{a}$ Ana Paula U. Araujo (IFSCUSP). Para evitar efeitos de agregação, as amostras foram mantidas em nitrogênio líquido até o momento das medições.

Os dados experimentais de espalhamento de raio-X a baixos ângulos (SAXS) foram obtidos utilizando a linha de SAXS1 do Laboratório Nacional de Luz Síncrotron (LNLS). Cada uma das curvas apresentadas é o resultado de uma tomada de dados com tempo de aquisição de 190 segundos. Nos gráficos, o tempo indicado nas legendas refere-se ao intervalo total desde o início da medição.

As curvas apresentadas estão em escala absoluta, utilizando a água como padrão 14.

O intervalo do vetor de espalhamento utilizado foi: $0,0113 \leq q \leq 0,4554 \AA^{-1}$. Sendo a dimensão máxima medida pela técnica dada por [15]:

$$
D_{\text {máx }}=\frac{\pi}{q_{\min }}=\frac{\pi}{0,0113} \approx 278 \AA
$$

\subsection{Análise das curvas de SAXS utilizando combinação de modelos}

Para análise dos resultados referentes às septinas utilizou-se a combinação linear de três modelos: proteína dimérica, cilindro (representando os oligômeros) e Porod (representando os agregados com dimensão maior que o limite de detecção da técnica experimental). As análises modelo-dependentes das curvas de SAXS foram feitas utilizando-se o programa GENFIT [16], [17], desenvolvido pelo Prof. Francesco Spinozzi.

A intensidade de espalhamento do monômero e do dímero pode ser escrita como:

$$
I_{\text {dímero ou monômero }}(q)=n_{\text {dímero ou monômero }} P_{\text {dímero ou monômero }}(q)
$$

onde o fator de forma $P_{\text {dímero ou monômero }}(q)$ é calculado pelo programa a partir da estrutura 
cristalográfica da proteína. No nosso caso, a estrutura cristalográfica utilizada foi a da SEPT2G, adaptada do arquivo pdb código 2QA5, excluindo-se os 15 primeiros aminoácidos. Uma melhor descrição da adaptação da estrutura cristalográfica pode ser encontrada na referência [12]. A estrutura da SEPT6G está em fase de refinamento e ainda não foi publicada. Devido a grande homologia e peso molecular semelhante da SEPT6G com a SEPT2G (comunicação privada com a Prof. ${ }^{a}$ Ana Paula U. Araujo, IFSC-USP), a estrutura cristalográfica da SEPT2G também será utilizada para as análises das amostras de SEPT6G.

As densidades numéricas de monômeros $n_{\text {monômero }}$ dímeros $n_{\text {dímero }}$ é dada por:

$$
\begin{gathered}
n_{\text {monomero }}=x_{\text {monômero }} 6,022 \times 10^{-4} \frac{c}{w_{\text {molec }}} \\
n_{\text {dímero }}=x_{\text {dímero }}\left(1-x_{\text {monômero }}\right) 6,022 \times 10^{-4} \frac{c}{2 w_{\text {molec }}}
\end{gathered}
$$

onde $x_{\text {monômero }}$ e $x_{\text {dímero }}\left(1-x_{\text {monômero }}\right)$ são as frações numéricas de monômeros e dímeros, respectivamente, $c$ é a concentração em $g / L$ de proteína, $w_{\text {molec }}=34 k D a$ a massa molecular do monômero da SEPT6G e $6,022 \times 10^{-4}$ é o fator de conversão de mol $/ L$ para partículas $/ \AA^{3}$.

A intensidade de espalhamento atribuida aos cilindros é descrita pela seguinte equação[18, 19]:

$$
I_{\text {cilindro }}(q)=n_{\text {cilindro }}\left(2 \pi R^{2} L \Delta \rho_{\text {cilindro }}\right)^{2} \int_{0}^{1}\left(\frac{J_{1}\left(q R \sqrt{1-x^{2}}\right) \operatorname{sen}(q L x / 2)}{q^{2} R \sqrt{1-x^{2}} L x / 2}\right)^{2} \mathrm{~d} x
$$

Onde $J_{1}(x)$ é a função de Bessel de $1^{\mathrm{a}}$ ordem, $R$ é o raio do cilindro, $L$ o comprimento e $\Delta \rho_{\text {cilindro }}$ o contraste de densidade eletrônica entre o cilindro e o solvente $\left(\rho_{0}=0,334 \frac{e}{\AA^{3}}\right)$ e $n_{\text {cilindro }}$ a densidade numérica de cilindros. Para vincular a porcentagem de proteína na forma de dímero, cilindro e Porod reescrevemos $n_{\text {cilindro }}$ como:

$$
n_{\text {cilindro }}=x_{\text {cilindro }}\left(1-x_{\text {dímero }}\right)\left(1-x_{\text {monômero }}\right) 6,022 \times 10^{-4} \times 0,28^{2} \frac{c}{w_{\text {molec }} N_{\text {agg }}}
$$

onde $x_{\text {cilindro }}\left(1-x_{\text {dímero }}\right)\left(1-x_{\text {monômero }}\right)$ é a fração numérica de proteínas agregadas formando um envelope cilíndrico e $N_{a g g}$ representa o número de monômeros de proteína que compõem o cilindro. Sendo o raio do elétron dado por $r_{e}=0,28 \times 10^{-12} \mathrm{~cm}$, o fator 0,28 encontrado na expressão é o valor de conversão da densidade eletrônica proporcional 
à $\frac{10^{-12} \mathrm{~cm}}{\AA^{3}}$, que é a unidade utilizada no código do programa GENFIT, para a unidade de entrada de $\Delta \rho$ em $\frac{e}{\AA^{3}}$ [20]. Uma vez que a densidade eletrônica encontra-se elevada ao quadrado, o fator de conversão também leva a mesma potência.

Para o modelo de Porod, a função que descreve a intensidade de espalhamento é dada por:

$I_{\text {porod }}=\left(1-x_{\text {cilindro }}\right)\left(1-x_{\text {dímero }}\right)\left(1-x_{\text {monômero }}\right) 6,022 \times 10^{-4} \times 0,28^{2} \frac{c}{w_{\text {molec }}} V_{\text {monômero }}\left(\Delta \rho_{\text {Porod }}\right)^{2} \sigma$

onde $\left(1-x_{\text {cilindro }}\right)\left(1-x_{\text {dímero }}\right)\left(1-x_{\text {monômero }}\right)$ é a fração numérica de proteínas no agregado tipo Porod, $\Delta \rho_{\text {Porod }}$ é o contraste de densidade eletrônica entre o agregado tipo Porod e o solvente e $\sigma=S / V$, sendo $S$ a superfície e $V$ o volume do agregado tipo Porod.

Além dos já apresentados, o modelo apresenta ainda o parâmetro $d_{c o r}$ que corresponde a porcentagem relativa de aumento de densidade eletrônica da camada de hidratação em relação à densidade eletrônica do solvente. A espessura da camada de hidratação foi fixada em $3 \AA$.

A contribuição de cada um dos modelos na intensidade de espalhamento é dada por:

$$
\begin{array}{r}
\%_{\text {monomero }}=100 \times x_{\text {monomero }} \\
\%_{\text {dímero }}=100 \times x_{\text {dímero }} \times\left(1-x_{\text {monômero }}\right) \\
\%_{\text {cilindro }}=100 \times x_{\text {cilindro }} \times\left(1-x_{\text {dímero }}\right) \times\left(1-x_{\text {monômero }}\right) \\
\%_{\text {porod }}=100 \times\left(1-x_{\text {cilindro }}\right) \times\left(1-x_{\text {dímero }}\right) \times\left(1-x_{\text {monômero }}\right)
\end{array}
$$

Para calcular o número de monômeros contidos nos cilindros, $N_{\text {agg }}$, temos que:

$$
\begin{gathered}
V=\pi R^{2} L=N_{\text {agg }} V_{\text {monômero }}+V_{\mathrm{H}_{2} \mathrm{O}} \\
\rho_{\text {cilindro }}=\frac{\rho_{\text {proteina }} N_{\text {agg }} V_{\text {monômero }}+\rho_{0} V_{\mathrm{H}_{2} \mathrm{O}}}{N_{\text {agg }} V_{\text {monômero }}+V_{\mathrm{H}_{2} \mathrm{O}}}
\end{gathered}
$$

onde $V_{\text {monomero }}=40625 \AA^{3}$ é o volume do monômero da septina e $V_{H_{2} O}$ o volume de água nos cilindros. 
Reordenando a Equação 1.12 .

$$
N_{\text {agg }}=\frac{\pi R^{2} L-V_{\mathrm{H}_{2} \mathrm{O}}}{V_{\text {monômero }}}
$$

e a Equação 1.13 .

$$
\begin{gathered}
\rho_{\text {cilindro }} N_{\text {agg }} V_{\text {monômero }}+\rho_{\text {cilindro }} V_{\mathrm{H}_{2} \mathrm{O}}=\rho_{\text {proteina }} N_{\text {agg }} V_{\text {monômero }}+\rho_{0} V_{\mathrm{H}_{2} \mathrm{O}} \\
V_{\mathrm{H}_{2} \mathrm{O}}=\frac{\rho_{\text {proteina }} N_{\text {agg }} V_{\text {monômero }}-\rho_{\text {cilindro }} N_{\text {agg }} V_{\text {monômero }}}{\rho_{\text {cilindro }}-\rho_{0}} \\
V_{\mathrm{H}_{2} \mathrm{O}}=\frac{\left(\rho_{\text {proteina }}-\rho_{\text {cilindro }}\right) N_{\text {agg }} V_{\text {monômero }}}{\rho_{\text {cilindro }}-\rho_{0}}
\end{gathered}
$$

Sendo $\rho_{\text {proteína }}=0,4235 \frac{e}{\AA^{3}}$ [14] e $\rho_{0}=0,334 \frac{e}{\AA^{3}}$, temos:

$$
V_{\mathrm{H}_{2} \mathrm{O}}=\frac{0,4235-\rho_{\text {cilindro }}}{\rho_{\text {cilindro }}-0,334} N_{\text {agg }} V_{\text {monômero }}=a N_{\text {agg }} V_{\text {monômero }}
$$

com

$$
a=\frac{0,4235-\rho_{\text {cilindro }}}{\rho_{\text {cilindro }}-0,334}
$$

Substituindo a Eq. 1.18 na Eq. 1.14.

$$
\begin{gathered}
N_{\text {agg }}=\frac{\pi R^{2} L}{V_{\text {monômero }}}-a N_{\text {agg }} \\
N_{\text {agg }}(1+a)=\frac{\pi R^{2} L}{V_{\text {monômero }}} \\
N_{\text {agg }}=\frac{\pi R^{2} L}{V_{\text {monômero }}} \frac{1}{1+a}
\end{gathered}
$$




\subsection{Resultados e Discussão}

Na Figura 1.5 são mostradas as curvas de SAXS para SEPT6G ao longo do tempo para temperatura variável de $13{ }^{\circ} \mathrm{C}$ a $45{ }^{\circ} \mathrm{C}$. A curva contínua nos gráficos representa a curva simulada para o dímero da SEPT2G. Assim, é possível constatar que a curva no instante inicial a $13^{\circ} \mathrm{C}$ (Figura 1.5.A) pode ser descrita em sua maior parte pelo dímero. O aumento de intensidade em valores pequenos de $q$ indica a presença de agregados maiores que dímeros na solução. Entretanto, trabalhos anteriores indicaram também a presença de monômeros em condições semelhantes[13]. Assim sendo, estas curvas serão analisadas posteriormente por uma composição de modelos de monômero, dímero e cilindro (agregados pequenos), e adição de um modelo para representar agregados maiores, caso isso se mostre necessário.

Ao aumentar a temperatura, verifica-se na Figura 1.5.B, C e D um aumento significativo na intensidade de espalhamento na região de $q \leq 0,015 \AA^{-1}$. Tal resultado novamente sugere um aumento no processo de agregação da proteína dependente da temperatura. Esse comportamento é similar ao observado para a SEPT2G em condições semelhantes [12]. 
Estudo do processo de agregação da septina 6G (SEPT6G) e heterodímero

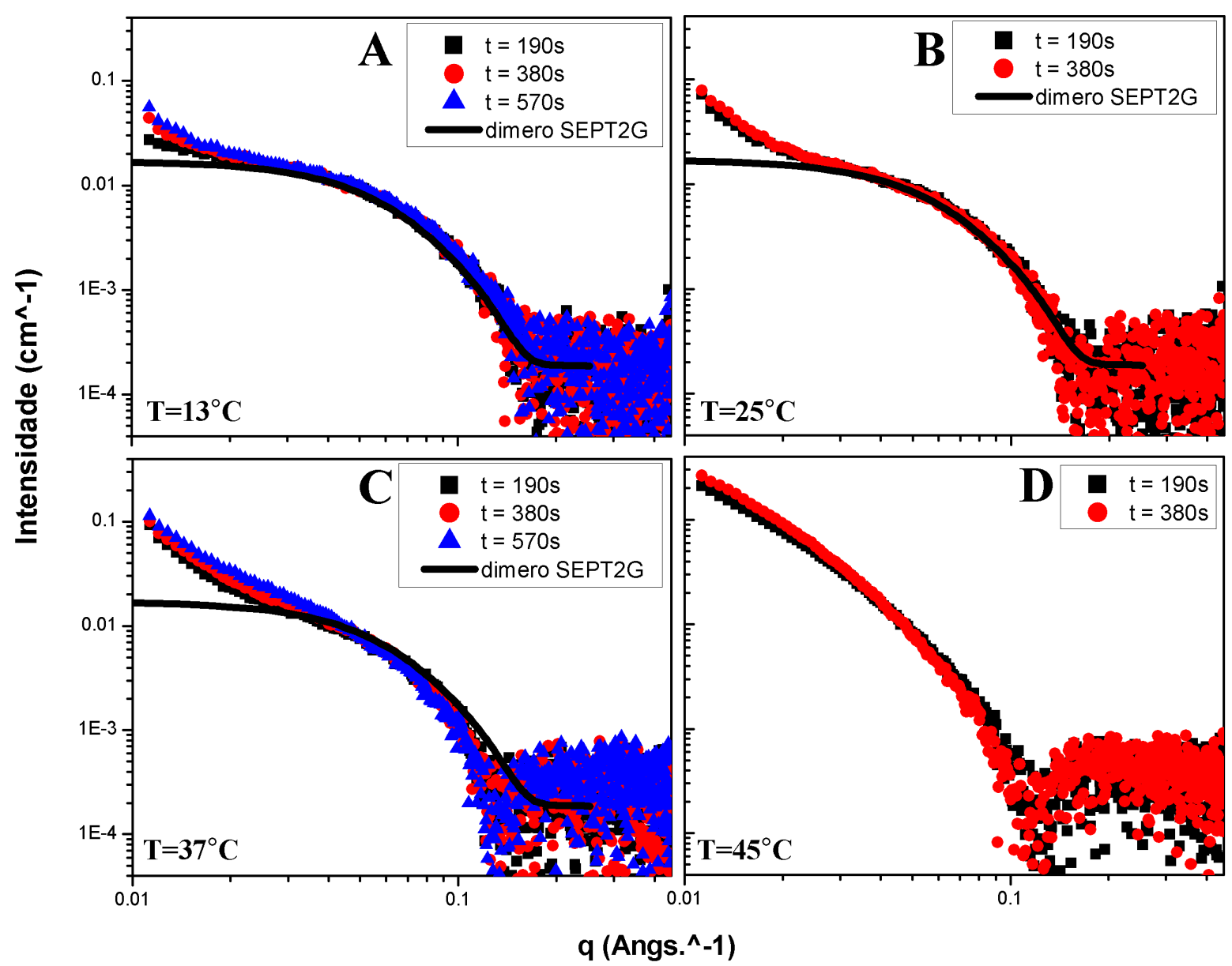

Figura 1.5: Evolução temporal das curvas de SAXS para a SEPT6G a (A) $\mathrm{T}=13^{\circ} \mathrm{C},(\mathrm{B}) \mathrm{T}=$ $25^{\circ} \mathrm{C}$, (C) $\mathrm{T}=37^{\circ} \mathrm{C}$ e (D) $\mathrm{T}=45^{\circ} \mathrm{C}$. Para efeito comparativo, a linha contínua nos gráficos indica o fator de forma $\mathrm{P}(\mathrm{q})$ correspondente ao espalhamento do dímero da SEPT2G. 
Os resultados das curvas de SAXS referentes ao heterodímero SEPT2G-SEPT6G estão dispostos nas Figuras 1.6 e 1.7. Nas Figuras 1.6. A a E é possível observar as curvas para as temperaturas de $10^{\circ} \mathrm{C}$ a $45^{\circ} \mathrm{C}$. Diferentemente dos dados para a SEPT6G, no caso do heterodímero, para as temperaturas analisadas não foram verificadas alterações ao longo do tempo. Assim sendo, para a análise modelo-dependente, serão feitas as médias de todo o intervalo de tempo medido para cada temperatura.

Em contraste com o observado para SEPT6G e SEPT2G isoladas, a $10^{\circ} \mathrm{C}$ a amostra possui alta intensidade de espalhamento para $q \leq 0,015 \AA^{-1}$, porém não há aumento da intensidade com o passar do tempo. Desta forma, verifica-se que devem existir agregados maiores que dímeros coexistindo com dímeros já a $10^{\circ} \mathrm{C}$, porém tais agregados não evoluem com o tempo. Adicionalmente, as curvas não apresentaram grandes alterações dependentes da temperatura até $45^{\circ} \mathrm{C}$. 
Estudo do processo de agregação da septina 6G (SEPT6G) e heterodímero

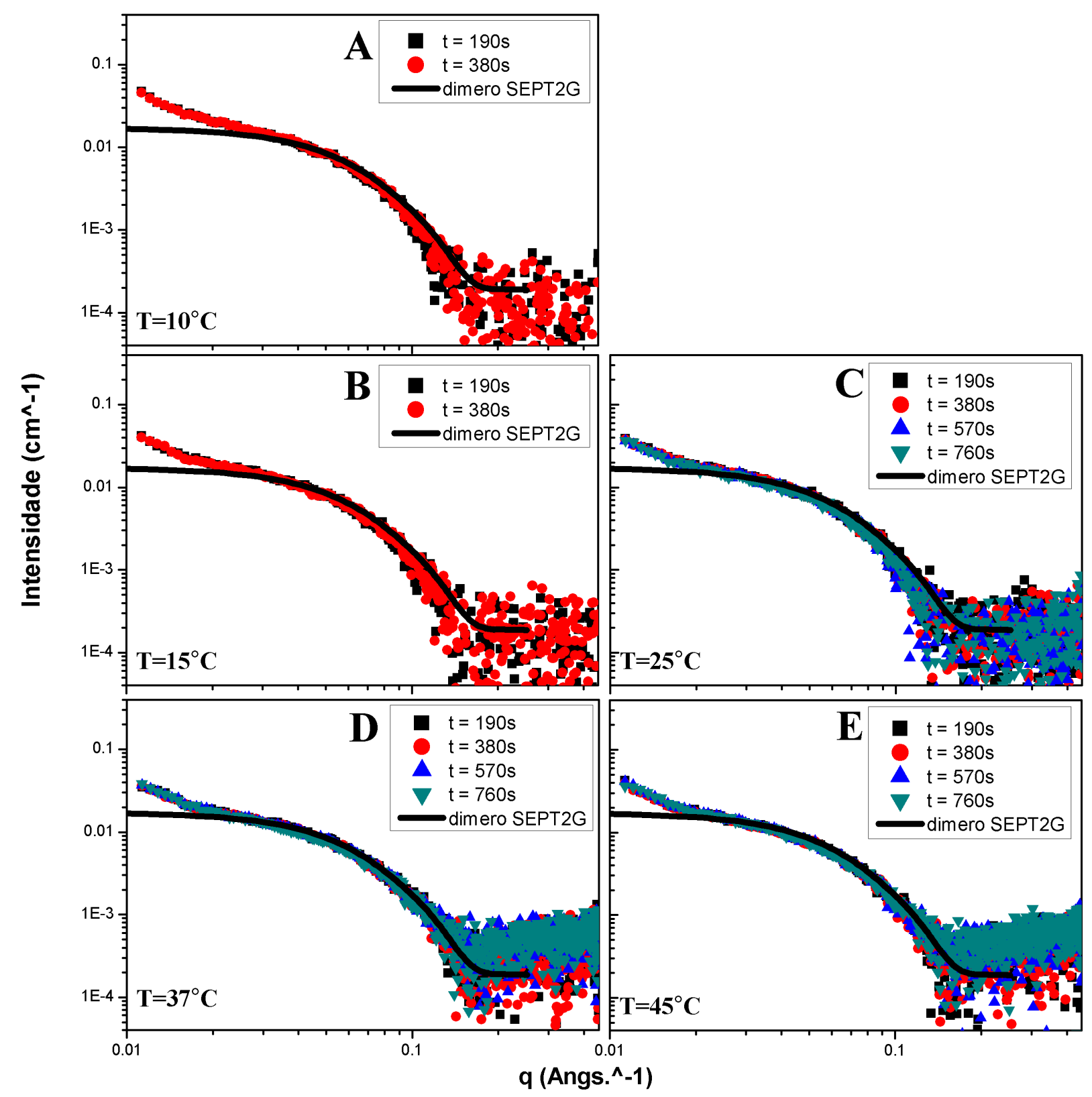

Figura 1.6: Evolução temporal das curvas de SAXS para o heterodímero SEPT2G-SEPT6 a (A) $\mathrm{T}=10^{\circ} \mathrm{C},(\mathrm{B}) \mathrm{T}=15^{\circ} \mathrm{C},(\mathrm{C}) \mathrm{T}=25^{\circ} \mathrm{C},(\mathrm{D}) \mathrm{T}=37^{\circ} \mathrm{C}$ e $(\mathrm{E}) \mathrm{T}=45^{\circ} \mathrm{C}$. Para efeito comparativo, a linha contínua nos gráficos indica indica o fator de forma $\mathrm{P}(\mathrm{q})$ correspondente ao espalhamento do dímero da SEPT2G. 
Para temperaturas acima de $45^{\circ} \mathrm{C}$ (Figura 1.7) a superposição da $\mathrm{P}(\mathrm{q}$ ) dimérica falha na região de $q \leq 0,1 \AA^{-1}$. O processo de agregação é intensificado pela temperatura e ao longo do tempo para uma mesma temperatura, indicado pelo aumento de intensidade para baixos valores de q. Dessa forma, a análise sem utilização de modelos já indica que o heterodímero SEPT2G-SEPT6G é termodinamicamente mais estável que a SEPT6G e SEPT2G separadamente.

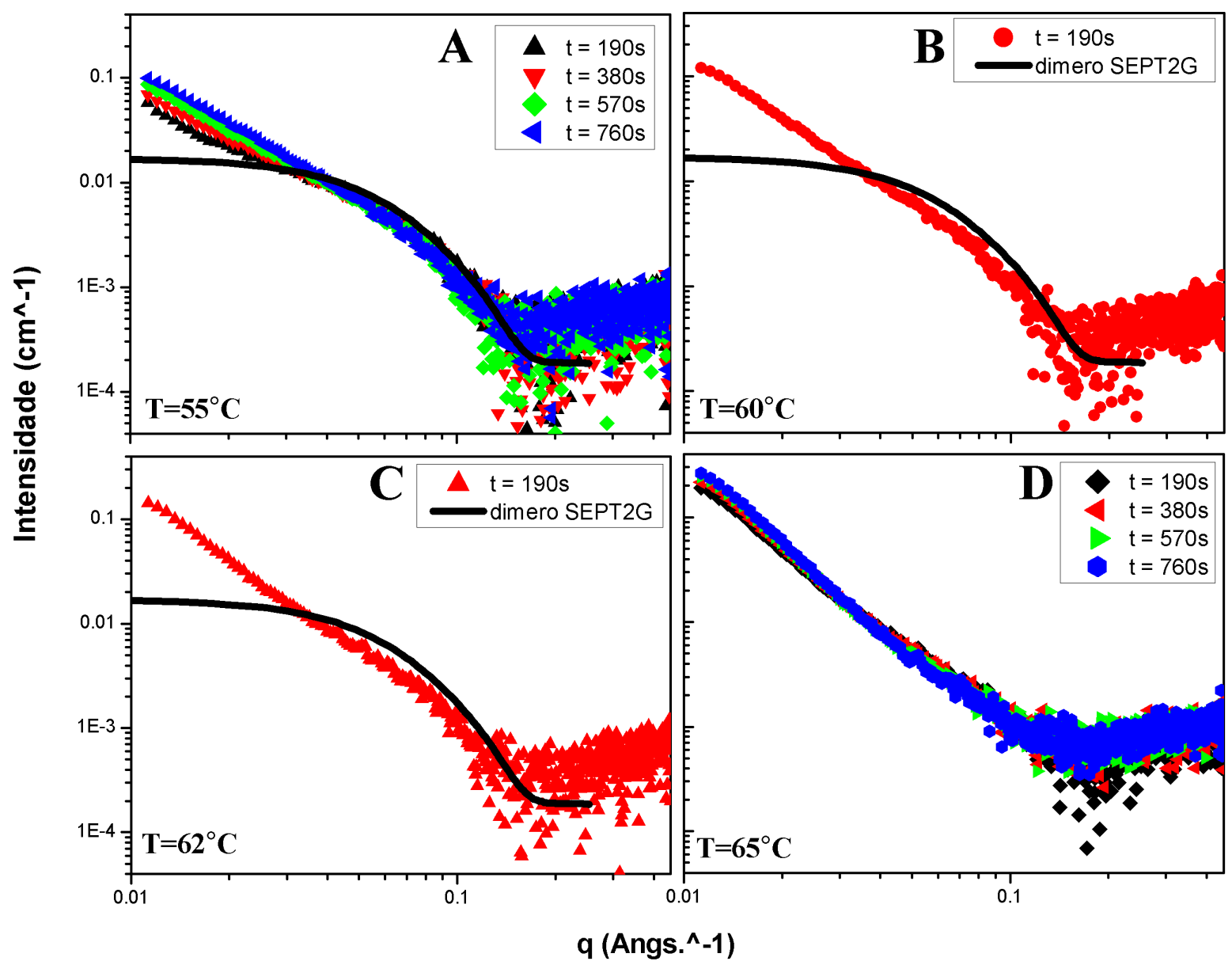

Figura 1.7: Evolução temporal das curvas de SAXS para o heterodímero SEPT2G-SEPT6G a (A) $\mathrm{T}=55^{\circ} \mathrm{C},(\mathrm{B}) \mathrm{T}=60^{\circ} \mathrm{C},(\mathrm{C}) \mathrm{T}=62^{\circ} \mathrm{C}$ e (D) $\mathrm{T}=65^{\circ} \mathrm{C}$. Para efeito comparativo, a linha contínua nos gráficos indica o fator de forma $\mathrm{P}(\mathrm{q})$ correspondente ao espalhamento do dímero da SEPT2G. 


\subsection{Análise modelo-dependente}

Tendo como base a análise inicial mostrada na seção anterior e visando melhor compreender a formação de fibras amilóides a partir de monômeros, dímeros e heterodímeros, usaremos a mesma abordagem aplicada à análise da SEPT2G [12]. Para tanto, são utilizados quatro modelos: as estruturas básicas descritas pelo monômero e dímero da proteína, um objeto cilíndrico e agregados maiores cujas dimensões ultrapassam o limite da técnica experimental e o espalhamento observado no intervalo de $q$ estudado segue a lei $I(q) \propto q^{-4}$ (região de Porod). As contribuições dos diferentes modelos foram avaliadas através dos parâmetros indicados na Seção 1.4. Além dos parâmetros de ajuste, foram calculadas outras variáveis para uma melhor interpretação do sistema. São elas: a porcentagem de proteína na forma de monômero $\left(\%_{\text {monômero }}\right)$, dímero $\left(\%_{\text {dímero }}\right)$, de agregados do tipo cilindro $\left(\%_{\text {cilindro }}\right)$ e agregados do tipo Porod $\left(\%_{\text {porod }}\right)$ e o número de septinas compreendidas dentro do agregado do tipo cilindro $\left(N_{\text {agreg }}\right)$.

Como exemplo de ajuste utilizando o programa GENFIT, a Figura 1.8 mostra a curva experimental para a SEPT2G-SEPT6G a $\mathrm{T}=55^{\circ} \mathrm{C}$ e $\mathrm{t}=380 \mathrm{~s}$. A linha preta indica o melhor ajuste obtido para este conjunto de dados, utilizando a soma dos modelos citados anteriormente. As linhas azul, verde e rosa indicam as contribuições do dímero, cilindro e agregado do tipo Porod, respectivamente. O comportamento da região $q \geq 0,06 \AA^{-1}$ é bem descrita pelo dímero, a menos de uma pequena diferença entre a curva simulada e a curva experimental. Para tanto, se fez necessária a adição de um fundo, representado pela linha tracejada. A presença de agregados maiores que o limite experimental da técnica, é representada pelo modelo de Porod, que tem grande influência para valores de $q \leq 0,015 \AA^{-1}$. Por fim, a adição do modelo de agregados do tipo cilindro melhora o ajuste principalmente na região compreendida entre $0,015 \leq q \leq 0,06 \AA^{-1}$. 


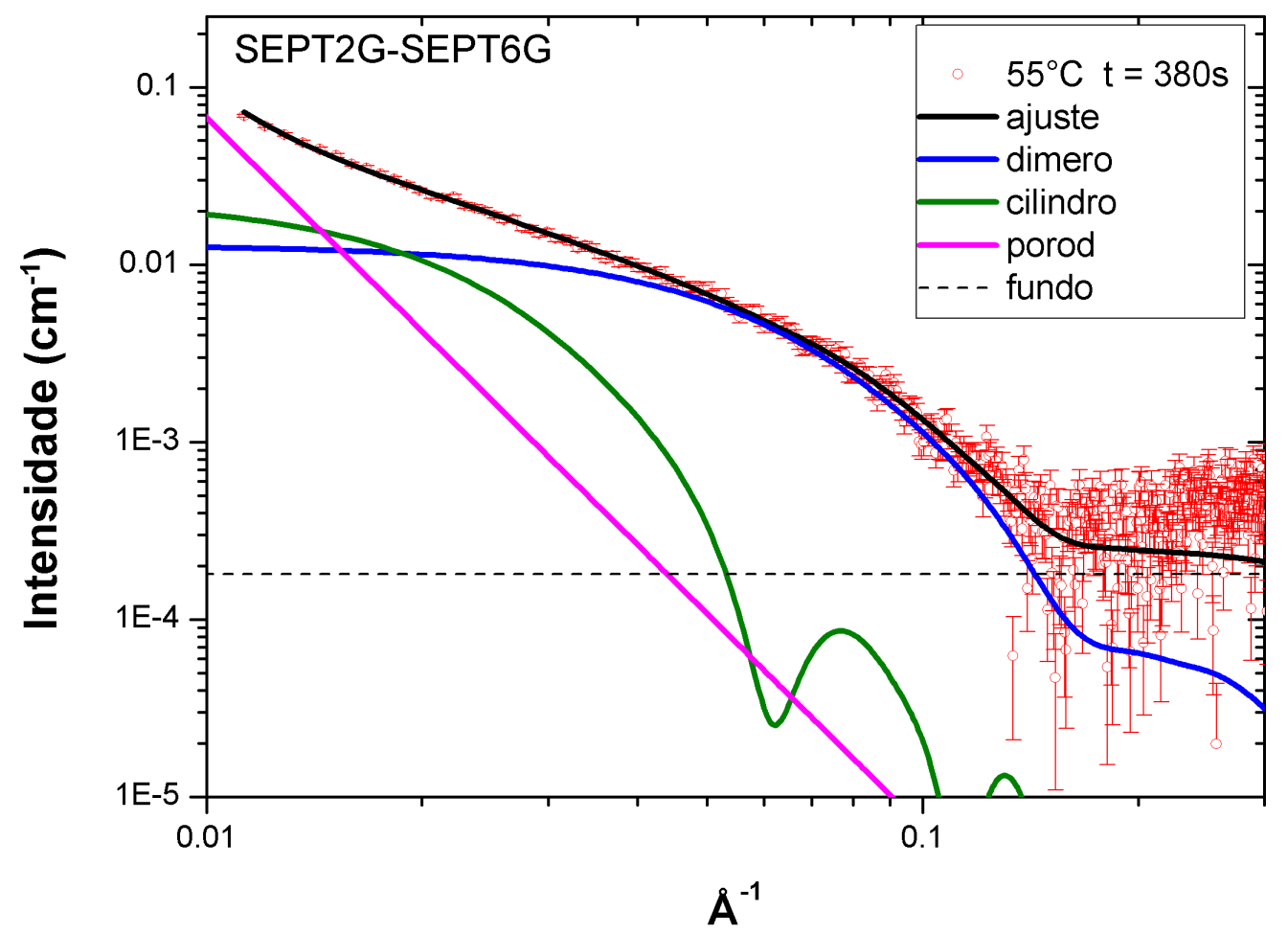

Figura 1.8: Exemplo de ajuste da curva de SAXS resultante para a SEPT2G-SEPT6G a $\mathrm{T}=55{ }^{\circ} \mathrm{C}$ e $\mathrm{t}=380 \mathrm{~s}$, utilizando os modelos de dímero, agregado do tipo cilindro e do tipo Porod, com contribuições de $61 \%, 5 \%$ e $34 \%$, respectivamente (Tabela 1.3). 


\subsubsection{SEPT6G}

Na Figura 1.9 podem ser observadas todas as curvas experimentais referentes à SEPT6G, bem como os melhores ajustes para cada curva, representados pelas linhas contínuas. Em todos os ajustes foi necessária a adição de um fundo da ordem de $10^{-4} \mathrm{~cm}^{-1}$ devido a diferença de temperatura da curva de SAXS do tampão com relação às demais. Na Tabela 1.1 são apresentadas as porcentagens dos modelos de monômero, dímero, cilindro e agregado do tipo Porod nos ajustes experimentais para SEPT6G e na Tabela 1.2 estão os parâmetros de ajuste obtidos. Os valores em parênteses nas tabelas representam as incertezas associadas a cada parâmetro. Tal notação será utilizada ao longo desta tese.

Para as curvas a $13^{\circ} \mathrm{C}$ (Figura 1.9.A), foi observada a presença de monômeros em solução em uma pequena porcentagem (até $3 \%$ ), mas a predominância é de dímeros em solução (até aproximadamente 96\%). Esta formação dimérica da SEPT6G não ocorre em condições fisiológicas e deve estar correlacionada ao preparo da amostra sem a presença de sal, que normalmente é utilizado para evitar a polimerização, bem como o congelamento e descongelamento da amostra. Como citamos previamente, trabalhos anteriores também indicaram a presença de monômeros, dímeros e agregados maiores em condições semelhantes, sem a adição de sal [13]. Entretanto, dados de cromatografia ainda não publicados do grupo da Prof. ${ }^{a}$ Ana Paula U. Araujo indicam que não há a presença de dímeros quando a amostra é analisada logo após a purificação, com sal e sem o congelamento e descongelamento da amostra.

Para as amostras a $25^{\circ} \mathrm{C}$ e $37^{\circ} \mathrm{C}$ foi verificada a presença de dímeros, agregados intermediários cilíndricos e agregados maiores do tipo Porod. A porcentagem de monômeros para estas condições é menor que $0,1 \%$. Dessa forma, as amostras para temperaturas maiores ou iguais a $\mathrm{T}=25^{\circ} \mathrm{C}$ foram analisadas sem o modelo do monômero. Como é mostrado nas Tabelas 1.1 e 1.2 , a porcentagem de dímeros diminui com o tempo e aumento de temperatura, dando origem aos agregados cilíndricos e do tipo Porod. Além disso, o tamanho e número de monômeros dentro de cada um dos cilindros se mantém constante, aumentando apenas sua porcentagem.

Com relação ao parâmetro referente à densidade eletrônica relativa da camada de hidratação $\mathrm{d}_{\text {cor }}$, os valores obtidos indicam um aumento de aproximadamente $15 \%$ com relação à densidade eletrônica do solvente.

Na Figura 1.9. D é possível observar as melhores tentativas de ajustes para as amostras 
a $\mathrm{T}=45^{\circ} \mathrm{C}$. Como podemos observar, uma composição de modelos de dímero, cilindro e agregados longos não ajusta bem os dados experimentais. Muito provavelmente outro(s) tipo(s) de agregado(s) pode(m) estar se formando e coexistindo na amostra, mas os quais não temos como defini-los experimentalmente por SAXS. De fato, resultados de fluorescência de ThT ainda não publicados (comunicação privada com a Prof. a Ana Paula U Araujo, IFSCUSP) sugerem a formação de agregados amorfos não amiloidais para temperatura de $45^{\circ} \mathrm{C}$ e superiores.

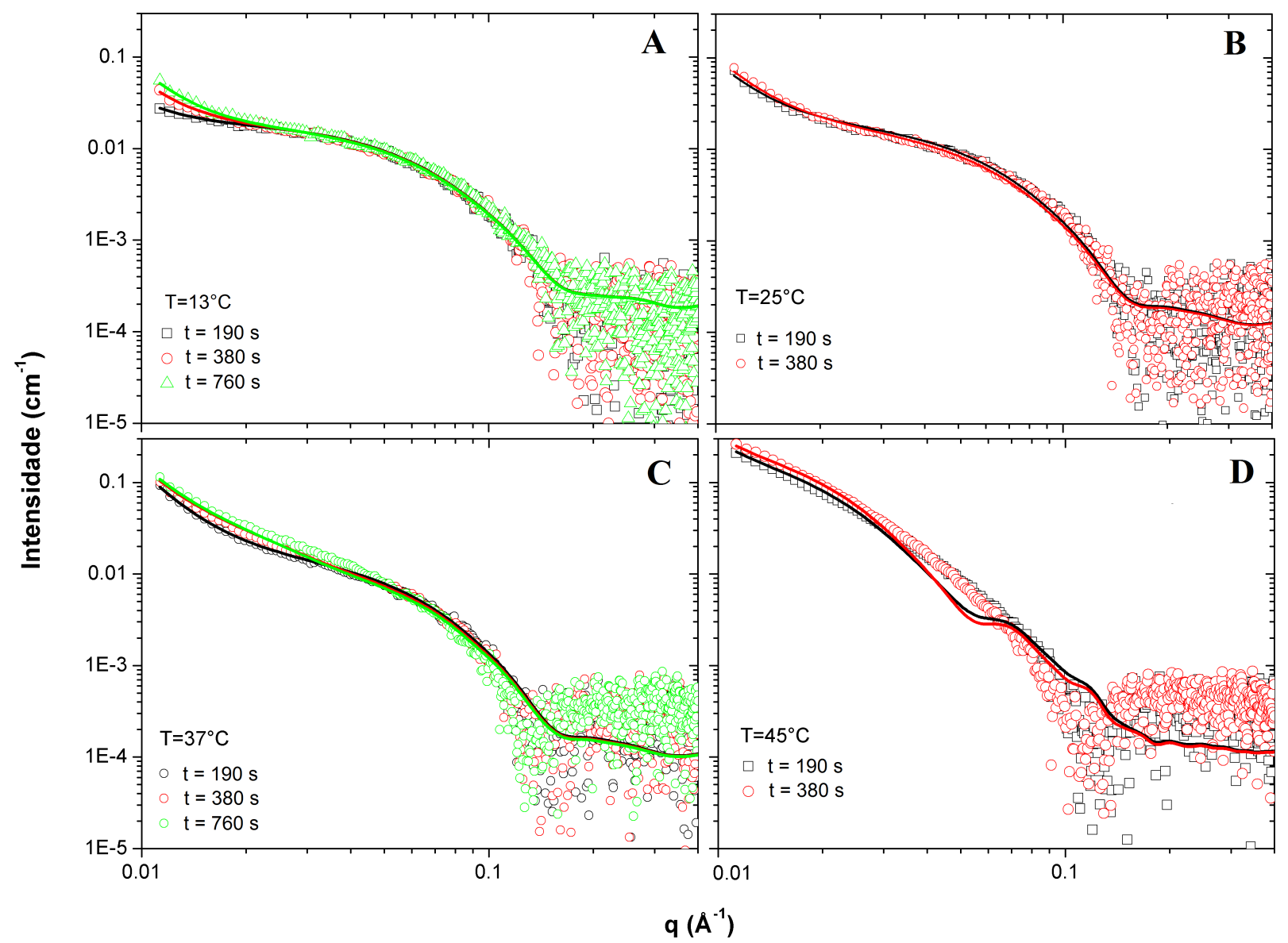

Figura 1.9: Evolução temporal e ajustes das curvas de SAXS para a SEPT6G a (A) T= $13^{\circ} \mathrm{C},(\mathrm{B}) \mathrm{T}=25^{\circ} \mathrm{C},(\mathrm{C}) \mathrm{T}=37^{\circ} \mathrm{C}$ e (D) $\mathrm{T}=45^{\circ} \mathrm{C}$. As linhas contínuas indicam os melhores ajustes obtidos para cada conjunto de dados. 
Tabela 1.1: Porcentagens dos modelos de monômero, dímero, cilindro e agregado do tipo Porod nos ajustes experimentais para SEPT6G (conforme descritos na Seção 1.4).

\begin{tabular}{c|c|c|c|c|c}
\hline $\mathrm{T}\left({ }^{\circ} \mathrm{C}\right)$ & $\mathrm{t}(\mathrm{s})$ & $\%_{\text {monômero }}$ & $\%_{\text {dímero }}$ & $\%_{\text {cilindro }}$ & $\%_{\text {porod }}$ \\
\hline \multirow{3}{*}{13} & 190 & $2,8(7)$ & $96,4(5)$ & - & $0,8(5)$ \\
& 380 & $3(1)$ & $95(1)$ & - & $2(1)$ \\
& 760 & $1,5(5)$ & $95,6(5)$ & - & $2,9(5)$ \\
\hline \multirow{2}{*}{25} & 190 & - & $66,5(1)$ & $0,9(5)$ & $32,6(5)$ \\
& 380 & - & $60(1)$ & $2(1)$ & $38(1)$ \\
\hline \multirow{3}{*}{37} & 190 & - & $55,5(4)$ & $0,7(3)$ & $43,8(3)$ \\
& 380 & - & $51,0(5)$ & $4(1)$ & $45(1)$ \\
& 760 & - & $48,5(5)$ & $4,7(2)$ & $46,8(5)$ \\
\hline \hline \multirow{2}{*}{$45\left(^{*}\right)$} & 190 & - & $37(1)$ & $18(1)$ & $45(1)$ \\
& 380 & - & $30(1)$ & $22(1)$ & $48(1)$ \\
\hline
\end{tabular}

${ }^{*}$ ) A composição de modelos não ajusta satisfatoriamente as curvas de SAXS a $\mathrm{T}=45^{\circ} \mathrm{C}$. Entretanto, apenas como referência, são mostradas na Tabela os parâmetros referentes às tentativas de ajustes que mais se aproximam da curva experimental. 
Tabela 1.2: Parâmetros dos ajustes experimentais para SEPT6G (conforme descritos na Seção 1.4).

\begin{tabular}{|c|c|c|c|c|c|c|c|c|c|}
\hline & & MONÔMERO E DÍMERO & \multicolumn{4}{|c|}{ CILINDRO } & \multicolumn{2}{|c|}{ POROD } & FUNDO \\
\hline $\begin{array}{c}\mathrm{T} \\
\left({ }^{\circ} \mathrm{C}\right)\end{array}$ & $\begin{array}{c}\mathrm{t} \\
(\mathrm{s})\end{array}$ & $d_{c o r}$ & $\begin{array}{l}\mathrm{R} \\
(\AA)\end{array}$ & $\begin{array}{c}\mathrm{L} \\
(\AA)\end{array}$ & $\begin{array}{c}\rho_{\text {cilindro }} \\
\left(e^{-} / \AA^{3}\right)\end{array}$ & $N_{a g g}$ & $\begin{array}{c}\rho_{\text {porod }} \\
\left(e^{-} / \AA^{3}\right)\end{array}$ & $\begin{array}{c}\sigma \\
\left(\times 10^{-3}\right)\end{array}$ & $\left(\times 10^{-4} \mathrm{~cm}^{-1}\right)$ \\
\hline 13 & $\begin{array}{l}190 \\
380 \\
760\end{array}$ & $1,12(1)$ & - & - & - & - & $0,38(2)$ & $29(5)$ & $1,8(1)$ \\
\hline 25 & $\begin{array}{l}190 \\
380\end{array}$ & $1,15(1)$ & $74(6)$ & $258(38)$ & $0,38(1)$ & $110(13)$ & $0,36(1)$ & $7,4(1)$ & $1,0(1)$ \\
\hline 37 & $\begin{array}{l}190 \\
380 \\
760\end{array}$ & $1,15(3)$ & $77(2)$ & $216(18)$ & $0,40(1)$ & $100(3)$ & $0,40(1)$ & $3(1)$ & $1,0(1)$ \\
\hline $45^{(*)}$ & $\begin{array}{l}190 \\
380\end{array}$ & $1,00(4)$ & $73(2)$ & $242(4)$ & $0,42(1)$ & $100(3)$ & $0,41(1)$ & $2,2(5)$ & $1,0(1)$ \\
\hline
\end{tabular}

\footnotetext{
${ }^{*}$ ) A composição de modelos não ajusta satisfatoriamente as curvas de SAXS a T $=45^{\circ} \mathrm{C}$. Entretanto, apenas como referência, são mostradas na Tabela os parâmetros referentes às tentativas de ajustes que mais se aproximam da curva experimental.
} 


\subsubsection{SEPT2G-SEPT6G}

De maneira análoga ao feito para a SEPT6G, a Figura 1.10 mostra os melhores ajustes das curvas de SAXS utilizando os modelos de dímero, cilindro e agregado do tipo Porod. Para todas as condições analisadas, a porcentagem do modelo de monômero seria inferior a $0,1 \%$. Desta forma, o modelo de monômero não foi utilizado para a análise da SEPT6GSEPT2G. A a adição de um fundo da ordem de $10^{-4} \mathrm{~cm}^{-1}$ foi necessária para a análise dos dados a temperaturas igual ou superiores a $55^{\circ} \mathrm{C}$ devido a diferença de temperatura da curva de SAXS do tampão com relação às demais. Na Tabela 1.3 são apresentadas as porcentagens dos modelos de dímero, cilindro e agregado do tipo Porod nos ajustes experimentais para SEPT2G-SEPT6G e na Tabela 1.4 estão os parâmetros de ajuste obtidos.

Na Figura 1.10, A estão os dados experimentais para a SEPT2G-SEPT6G a temperaturas de $10^{\circ} \mathrm{C}$ a $45^{\circ} \mathrm{C}$ e o melhor ajuste composto em sua maior parte (91\%) por dímeros e uma pequena porcentagem $(9 \%)$ de agregados maiores do tipo Porod. Estes resultados estão de acordo com dados de cromatografia para a amostra em condições semelhantes [13].

Para temperaturas de $55^{\circ} \mathrm{C}$ a $65^{\circ} \mathrm{C}$ (Figura 1.10 . B, C e D), verifica-se a presença de agregados cilíndricos, além dos agregados maiores do tipo Porod. Assim como o observado para a SEPT6G, a porcentagem de agregados aumenta com a temperatura e evolução temporal. Entretanto, diferentemente do visto para a SEPT6G, os agregados do tipo cilindro são inicialmente menores e aumentam em dimensão e número de monômeros neles contidos com o aumento de temperatura, bem como em porcentagem. Resultados de fluorescência de ThT ainda não publicados (comunicação privada com a Prof. a Ana Paula U Araujo, IFSC-USP) indicam a formação de agregados amilóides para SEPT2G-SEPT6G a temperatura de $55^{\circ} \mathrm{C}$ e superiores.

Para todas as temperaturas analisadas, verifica-se que a densidade eletrônica relativa da camada de hidratação $\mathrm{d}_{\text {cor }}$ apresenta valores até $15 \%$ superiores à densidade eletrônica do solvente. 


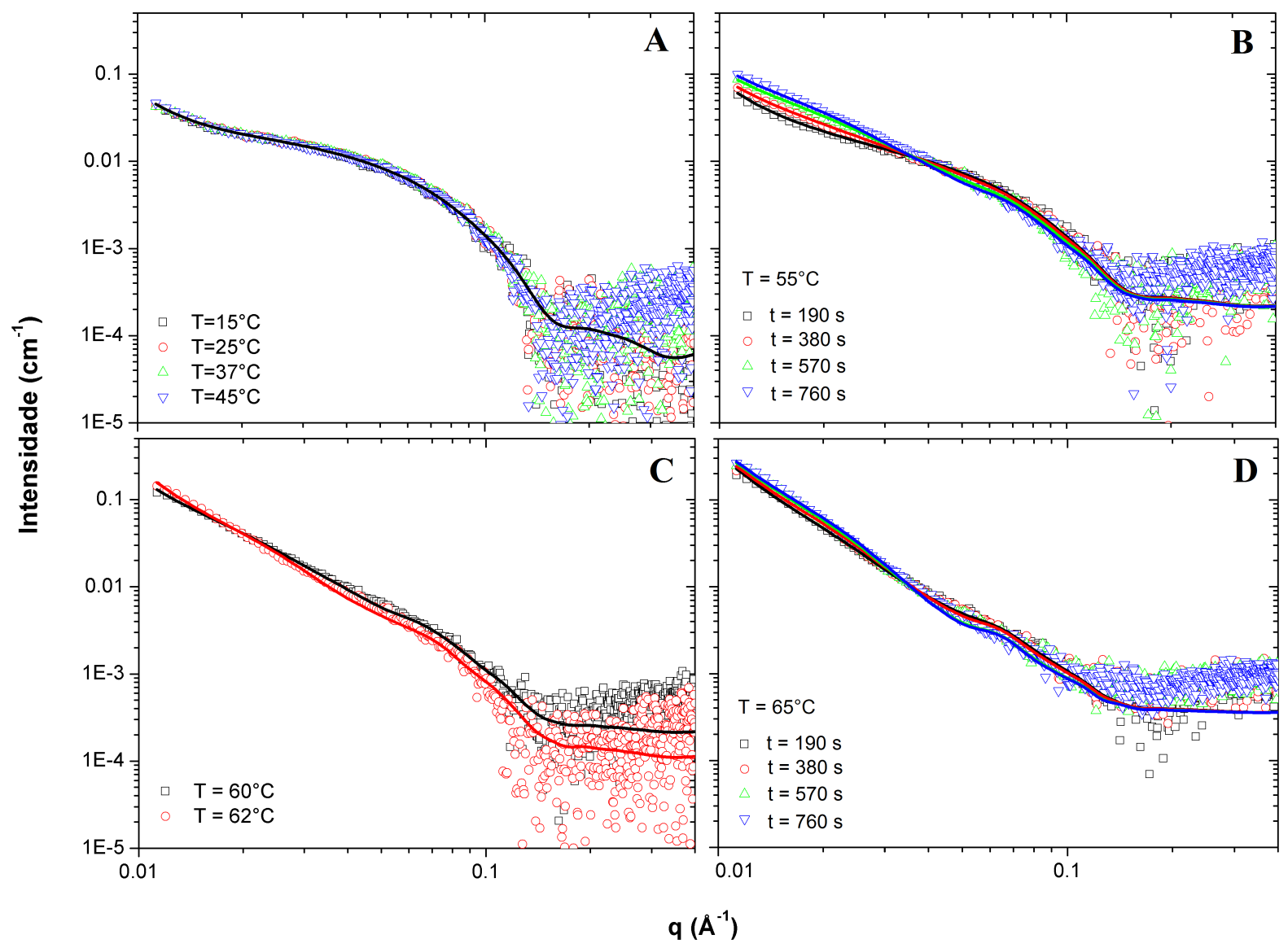

Figura 1.10: Evolução temporal e ajustes das curvas de SAXS para o heterodímero SEPT2G-SEPT6G a $(\mathrm{A}) \mathrm{T}=10^{\circ} \mathrm{C}$ a $\mathrm{T}=45^{\circ} \mathrm{C},(\mathrm{B}) \mathrm{T}=55^{\circ} \mathrm{C},(\mathrm{C}) \mathrm{T}=60^{\circ} \mathrm{C}$ e $\mathrm{T}=62^{\circ} \mathrm{C}$ e (D) $\mathrm{T}=65^{\circ} \mathrm{C}$. As linhas contínuas indicam os melhores ajustes obtidos para cada conjunto de dados. 
Estudo do processo de agregação da septina 6G (SEPT6G) e heterodímero

Tabela 1.3: Porcentagens dos modelos de dímero, cilindro e agregado do tipo Porod nos ajustes experimentais para SEPT2G-SEPT6G (conforme descritos na Seção 1.4).

\begin{tabular}{c|c|c|c|c}
\hline $\mathrm{T}\left({ }^{\circ} \mathrm{C}\right)$ & $\mathrm{t}(\mathrm{s})$ & $\%_{\text {dimero }}$ & $\%_{\text {cilindro }}$ & $\%_{\text {porod }}$ \\
\hline 10 & & & & \\
até & 760 & $91,0(5)$ & - & $9,0(5)$ \\
45 & & & & \\
\hline & 190 & $85(1)$ & $4,1(5)$ & $10,9(5)$ \\
55 & 380 & $79(2)$ & $8(1)$ & $13(1)$ \\
& 570 & $71(2)$ & $12(1)$ & $17(2)$ \\
& 760 & $66(2)$ & $17(2)$ & $17(2)$ \\
\hline 60 & 190 & $59(2)$ & $16(2)$ & $25(2)$ \\
\hline 62 & 190 & $30(1)$ & $9(1)$ & $61(1)$ \\
\hline & 190 & $29(1)$ & $6(1)$ & $65(1)$ \\
65 & 380 & $27(2)$ & $8(1)$ & $65(1)$ \\
& 570 & $21(1)$ & $9(1)$ & $70(1)$ \\
& 760 & $20(1)$ & $10(1)$ & $70(1)$ \\
\hline
\end{tabular}


Tabela 1.4: Parâmetros dos ajustes experimentais para SEPT2G-SEPT6G (conforme descritos na Seção 1.4).

\begin{tabular}{|c|c|c|c|c|c|c|c|c|c|}
\hline & & DÍMERO & \multicolumn{4}{|c|}{ CILINDRO } & \multicolumn{2}{|c|}{ POROD } & FUNDO \\
\hline $\begin{array}{c}\mathrm{T} \\
\left({ }^{\circ} \mathrm{C}\right)\end{array}$ & $\begin{array}{c}\mathrm{t} \\
(\mathrm{s})\end{array}$ & $d_{c o r}$ & $\begin{array}{c}\mathrm{R} \\
(\AA)\end{array}$ & $\begin{array}{c}\mathrm{L} \\
(\AA)\end{array}$ & $\begin{array}{c}\rho_{\text {cilindro }} \\
\left(e^{-} / \AA^{3}\right)\end{array}$ & $N_{a g g}$ & $\begin{array}{c}\rho_{\text {porod }} \\
\left(e^{-} / \AA^{3}\right)\end{array}$ & $\begin{array}{c}\sigma \\
\left(\times 10^{-3}\right)\end{array}$ & $\left(\times 10^{-4} \mathrm{~cm}^{-1}\right)$ \\
\hline $\begin{array}{l}10 \\
\text { até } \\
45\end{array}$ & 760 & $1,15(1)$ & $\begin{array}{l}- \\
- \\
-\end{array}$ & $\begin{array}{l}- \\
- \\
-\end{array}$ & $\begin{array}{l}- \\
- \\
-\end{array}$ & $\begin{array}{l}- \\
- \\
-\end{array}$ & $0,41(2)$ & $6,4(3)$ & 0 \\
\hline 55 & $\begin{array}{l}190 \\
380 \\
570 \\
760\end{array}$ & $1,06(1)$ & $64(8)$ & $222(50)$ & $0,40(1)$ & $70(10)$ & $0,40(1)$ & $7,5(1)$ & $1,8(1)$ \\
\hline 60 & 190 & $1,10(4)$ & $73(8)$ & $170(20)$ & $0,40(1)$ & $70(9)$ & $0,40(1)$ & $10(1)$ & $2,0(1)$ \\
\hline 62 & 190 & $1,15(2)$ & $76(2)$ & $223(15)$ & $0,40(1)$ & 101(4) & $0,36(2)$ & $8(1)$ & $1,0(1)$ \\
\hline 65 & $\begin{array}{l}190 \\
380 \\
570 \\
760\end{array}$ & $1,15(1)$ & $81(1)$ & $254(30)$ & $0,41(1)$ & $129(16)$ & $0,36(1)$ & $10(1)$ & $3,5(3)$ \\
\hline
\end{tabular}


Na Figura 1.11 é mostrada a comparação das porcentagens de monômero, dímero, cilindro e agregados grandes do tipo Porod em solução para as septinas SEPT2G, SEPT6G e SEPT2G-SEPT6G para os casos em que estes dados foram medidos. Os dados referentes à SEPT2G isolada correspondem aos resultados obtidos anteriormente na referência [12]. Vale a pena ressaltar que não foram incluídos os dados de SEPT2G-SEPT6G a temperaturas superiores a $45^{\circ} \mathrm{C}$ por não haver dados da SEPT2G e SEPT6G. Para estas condições, os valores estão dispostos na Tabela 1.3

Os resultados mostrados na Figura 1.11 evidenciam a termoestabilidade da SEPT2GSEPT6G quando comparada às septinas isoladas, para as temperaturas acima de $25^{\circ} \mathrm{C}$. Além disso, o heterodímero também se mostra mais estável quando a evolução temporal é analisada. Para $45^{\circ} \mathrm{C}$, após 760 s, 90\% da SEPT2G em solução já encontra-se agregada, enquanto que para as mesmas condições é observada a presença de apenas $9 \%$ de agregados grandes de SEPT2G-SEPT6G. Os dados referentes a amostra de SEPT6G a $45^{\circ} \mathrm{C}$ não foram incluidos devido ao modelo utilizado não descrever bem a amostra nestas condições. 

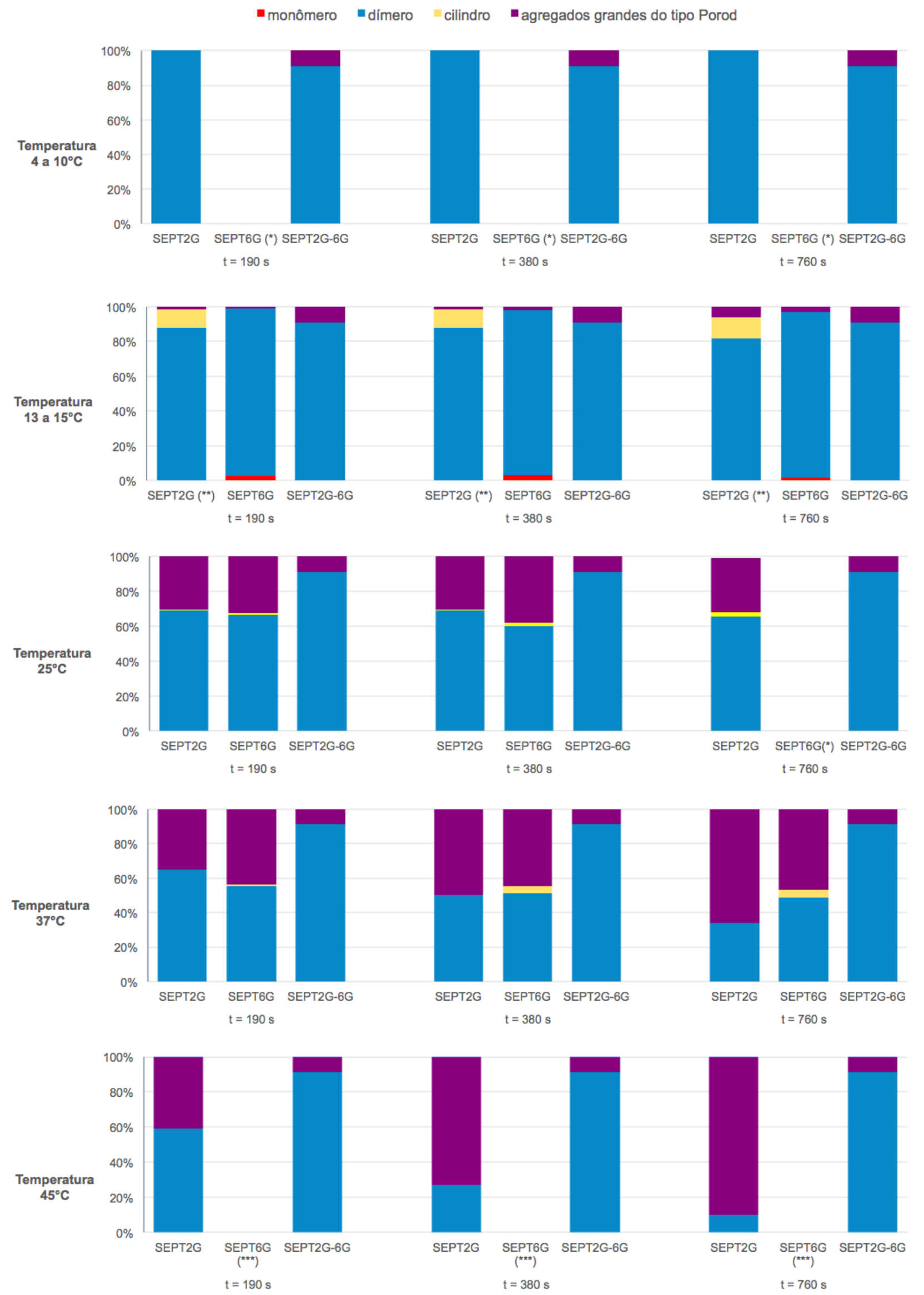

(*) Não há dados para estas condições. $\quad(* *)$ Cilindros são menores nestas condições, possuindo até 14 monômeros. (***) Modelo não foi satisfatório para ajustar os dados nestas condições.

Figura 1.11: Comparação das porcentagens de monômero, dímero, cilindro e agregados grandes do tipo Porod em solução para as septinas SEPT2G, SEPT6G e SEPT2G-SEPT6G. 


\subsection{Conclusão}

A SEPT6G a $13^{\circ} \mathrm{C}$ é predominantemente dimérica, apresentando apenas aproximadamente $3 \%$ de monômeros em solução. Entretanto, a formação dimérica pode estar relacionada ao preparo da amostra sem a presença de sal e ao processo de congelamento e descongelamento da amostra. Em condições de temperaturas iguais a $25^{\circ} \mathrm{C}$ e $37^{\circ} \mathrm{C}$ foi verificada a presença de dímeros coexistindo com agregados intermediários cilíndricos e agregados maiores do tipo Porod. Foi verificado que a porcentagem de dímeros diminui com a evolução temporal e com o aumento de temperatura, dando origem a agregados cilíndricos e agregados maiores que o limite da técnica experimental. A análise utilizada para as demais amostras não se mostrou satisfatória para descrever os resultados para a temperatura de $45^{\circ} \mathrm{C}$, indicando que possivelmente há a formação de agregados amorfos não amiloidais a partir desta temperatura.

Para SEPT2G-SEPT6G a temperaturas de $10^{\circ} \mathrm{C}$ a $45^{\circ} \mathrm{C}$ não foram verificadas alterações ao longo do tempo até aproximadamente 13 minutos de medida experimental, havendo 91\% de dímeros e uma pequena porcentagem, 9\%, de agregados maiores do tipo Porod. Acima de $45^{\circ} \mathrm{C}$ é possível observar a presença da forma dimérica, agregados cilíndricos e agregados maiores do tipo Porod. Da mesma forma que para SEPT6G, a porcentagem de agregados, bem como sua dimensão, aumentam com a temperatura e evolução temporal.

Desta forma, verifica-se que o heterodímero SEPT2G-SEPT6G é termodinamicamente mais estável que as septinas SEPT6G e SEPT2G isoladas. Para a SEPT6G a $45^{\circ} \mathrm{C}$ há a formação predominante de agregados amorfos de acordo com dados de fluorescencia de tioflavina, enquanto que para a mesma temperatura a SEPT2G-SEPT6G encontra-se em sua maior parte na forma dimérica. Portanto, nossos resultados parecem indicar que a formação de heterodímeros SEPT2G-SEPT6G, em particular, que fazem parte do hexamero funcional de SEPT2-SEPT6-SEPT7, são termodinamicamente mais estáveis que os homodímeros separadamente (SEPT2G-SEPT2G e SEPT6G-SEPT6G). 


\section{Capítulo 2}

\section{Estudo dos proteolipossomos de anexina V humana (A5) e proteína GPI-ancorada TNAP}

\subsection{Introdução}

As vesículas de matriz extracelular (MVs) são responsáveis pelo início da ossificação endocondral, sendo capazes de transportar cálcio para dentro da vesícula e hidrolisar fosfosubstratos na interface lipídeo-água. Fosfatidilcolina (PC) e fosfatidilserina (PS) são dois dos principais lipídeos encontrados nas membranas de MV. Alguns autores verificaram que esses lipídeos exercem um papel fundamental no processo de biomineralização, tanto regulando a entrada de cálcio, quanto na formação de cristais de hidroxiapatita [21] e [22]. Desta forma, a relação entre a composição lipídica e as características estruturais das membranas são cruciais para a validação dos sistemas miméticos do processo de biomineralização.

Dentre as proteínas mais abundantes nas MVs estão as anexinas e as fosfatases alcalinas. As anexinas constituem uma ampla família de proteínas ligantes de cálcio fosfolipídeodependentes que exercem um papel fundamental do inicio da mineralização por MVs e são as proteínas encontradas em maior número nas MVs. Mais especificamente, a anexina V humana (A5) é responsável por funções fisiológicas, tais como: inibição dependente de fosfolipídeo da coagulação sanguínea [23] e desorganização celular que resulta no processo de apoptose [24], formação de micropartículas derivadas da membrana plasmática[25], entre outros. 
A A5 é uma proteína de aproximadamente $33 \mathrm{kDa}$, com estrutura cristalográfica composta por quatro domínios compactos com 5 alpha-hélices cada. Esses domínios estão dispostos de maneira que definem um poro hidrofílico através do centro da proteína[26]. Tal poro apresenta atividade de canal de cálcio presente na membrana de MV[27], [22]. Na Figura 2.1 é possível observar uma representação da estrutura cristalográfica da A5 (código pdb $1 \mathrm{AVH})[26]$.
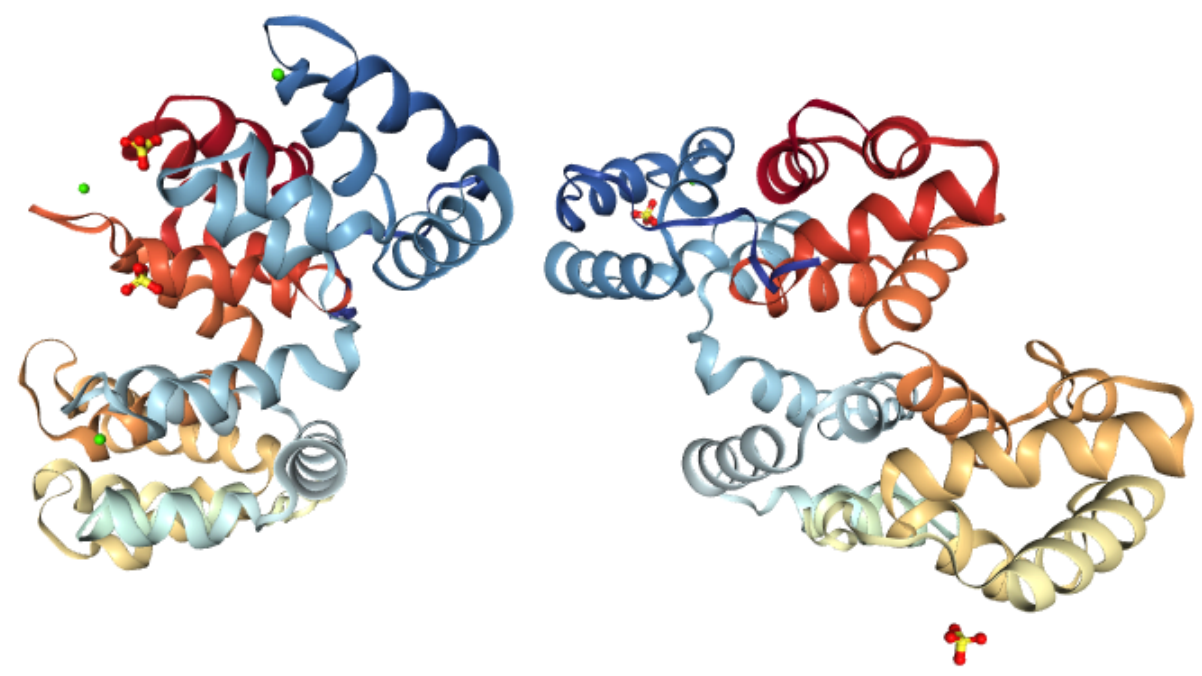

Figura 2.1: Representação do dímero da A5[26]. Imagem gerada utilizando o NGL Viewer[28], 29].

Oling e colaboradores [30] mostraram que, ao se ligarem em membranas, a A5 deve se organizar de maneira a formar trímeros ordenados em um plano. A forma trimérica de A5 também foi observada por Richter e colaboradores [31] em membranas de fosfolipídeos negativamente carregados na presença de cálcio. A estrutura cristalográfica deste trímero pode ser vista na Figura 2.2 .

Outros autores sugerem que há a formação de hexâmeros favorecidos por determinadas condições. Análises de cross-linking químico realizadas por Kirsh e colaboradores revelaram que lipossomos ricos em PS induzem a formação de hexâmeros de anexina V[32]. Tendo como base o estudo realizado com a anexina XII por Luecke e colaboradores [33], o hexâmero é composto por dois trímeros paralelos, conforme mostrado na Figura 2.3. Entretanto, ainda não existe um consenso na literatura sobre qual estrutura oligomérica de A5 é a mais provável de ser encontrada em contato com a membrana. 


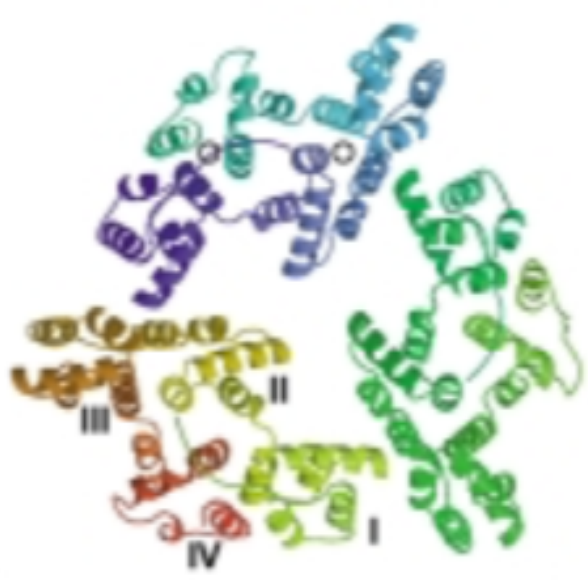

Figura 2.2: Estrutura cristalográfica do trímero da A5. I, II, III e IV indicam os 4 dominios do momomero de A5. Imagem extraída da referência 30.

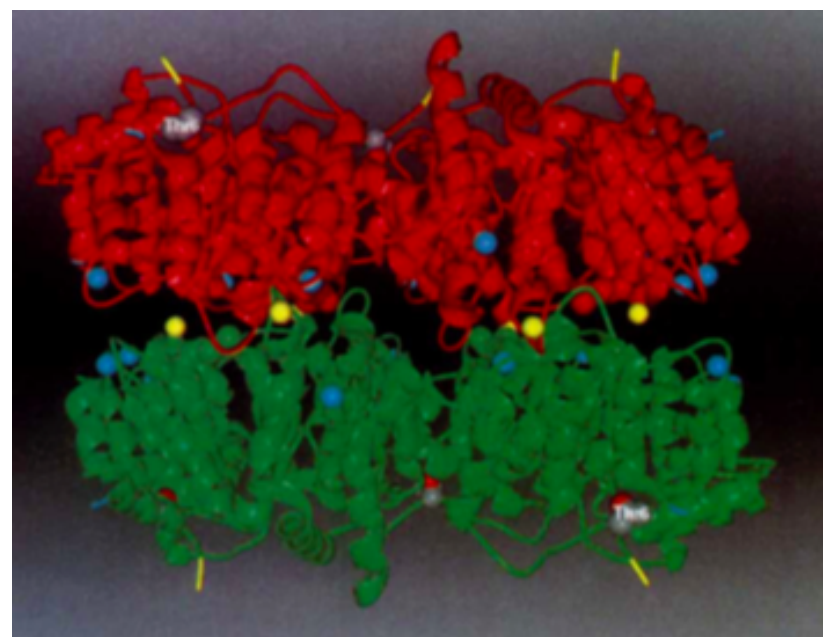

Figura 2.3: Estrutura cristalográfica do hexâmero da anexina XII, composta por dois trímeros paralelos. Imagem extraída da referência[33]. 
Ainda, é conhecido [34] que proteínas GPI-ancoradas tais como a fosfatase alcalina tecido não-específico (TNAP) estão preferencialmente localizadas na região de fase ordenada de lipídeos na membrana plasmática. A função primária da TNAP está relacionada com a degradação do pirofosfato inorgânico (PPi) extracelular, um inibidor de mineralização. Através do controle da concentração de PPi, mantém-se uma condição onde é possível a mineralização óssea [35].

Bolean e colaboradores [36] analisaram sistemas estáveis de proteolipossomos de DPPC e DPPC:DPPS contendo A5 e TNAP, seguido de sua caracterização e do estudo de como a presença de A5 impacta nos parâmetros da cinética da hidrólise dos substratos de TNAP em pH fisiológico. A melhor eficiência catalítica foi atingida para uma razão molar de 10\% de DPPS nos proteolipossomos, condições que também aumentaram a especificidade da hidrólise do PPi pela TNAP. Análises de calorimetria diferencial de varredura mostraram que a presença de 10\% de DPPS em lipossomos de DPPC causa um alargamento nos picos de transição de fase dos lipídeos, com A5 e TNAP promovendo um decréscimo nos valores de variação de entalpia. A5 foi capaz de mediar o fluxo de cálcio para dentro das vesículas de DPPC e DPPC:DPPS (9:1) em condições fisiológicas de concentrações de cálcio (aproximadamente 2 $\mathrm{mM}$ ). Este processo não foi afetado pela presença da TNAP nos proteolipossomos. Por outro lado, A5 afeta significativamente a hidrólise dos substratos de TNAP. Estudos com vesículas gigantes (GUVs) confirmaram a reconstituição funcional da A5 nos sistemas miméticos 36].

No presente trabalho, investigamos por Espalhamento de Raios-X a Baixos Ângulos (SAXS) as características estruturais de membranas modelo (LUVs) compostos por apenas DPPC, na presença e ausência de cálcio, DPPC:DPPS (9:1) na presença e ausência de cálcio e de proteolipossomos contendo A5 e A5 + TNAP.

\subsection{Objetivos}

O objetivo deste capítulo foi verificar possíveis alterações estruturais da membrana modelo de DPPC devido a presença de cálcio na solução, assim como alterações induzidas pela presença de DPPS na composição lipídica. Um segundo objetivo foi analisar as alterações induzidas na membrana pelas proteínas A5 e TNAP. 


\subsection{SAXS no Laboratório Nacional de Luz Síncrotron (LNLS)}

Os dados experimentais de espalhamento de raio-X a baixos ângulos (SAXS) foram obtidos utilizando a linha de SAXS1 do Laboratório Nacional de Luz Síncroton (LNLS). Cada uma das curvas apresentadas é o resultado de uma tomada de dados com tempo de aquisição de 100 segundos. Apesar da escala arbitrária, todos os dados experimentais foram medidos na mesma campanha, ou seja, mesmo dia e condições experimentais e a temperatura ambiente. Desta forma, a constante experimental é a mesma para todas as curvas apresentadas.

O intervalo do vetor de espalhamento utilizado foi: $0,012 \leq q \leq 0,454 \AA^{-1}$. Sendo a dimensão máxima medida pela técnica dada por [15]:

$$
D_{\text {máx }}=\frac{\pi}{q_{\min }}=\frac{\pi}{0,012} \approx 262 \AA
$$

\subsubsection{Lamelas e Multilamelas}

Para a análise de lipossomos e proteolipossomos foi utilizado o modelo de membrana infinita, devido ao diâmetro das vesículas extrusadas ser bem superior ao limite experimental de SAXS. Para a aplicação deste modelo é necessária a condição de que a dimensão da bicamada seja bem inferior às outras duas dimensões e que o raio da curvatura da bicamada seja muito superior à sua espessura. A intensidade de espalhamento é escrita como

$$
I(q)=k \frac{2 \pi}{q^{2}}|A(q)|^{2} S_{M C T}(q)
$$

Sendo $k$ a constante experimental relacionada ao arranjo experimental e

$$
\begin{gathered}
A(q)=\sum_{j=1}^{M} e^{i q(j-1)\left(R_{w}+2 z_{1}\right)} F(q) \\
F(q)=2 \sum_{i=1}^{3} z_{i}\left(\rho_{i}-\rho_{i-1}\right) j_{0}\left(q z_{i}\right) e^{-q \sigma_{i}{ }^{2} / 2}
\end{gathered}
$$




$$
S_{M C T}(q)=1+\frac{2}{N} \sum_{m=1}^{N-1}(N-m) \cos (m q d) \times(\pi m)^{-\left(d /(2 \pi)^{2} q^{2} \eta\right.} e^{-\gamma\left(d /(2 \pi)^{2} q^{2} \eta\right.}
$$

onde $N$ é o número de multilamelas, $d$ a distância de repetição entre as bicamadas e $\eta$ o parâmetro de Caillé que quantifica as flutuações das multilamelas[37, [38], [39].

Além destes parâmetros de ajuste, este modelo considera uma membrana composta por três camadas de diferentes densidades eletrônicas em relação ao solvente. São elas: região da cabeça polar, das cadeias $\mathrm{CH}_{2}$ e do grupo metil terminal $\mathrm{CH}_{3}$. A Figura 2.4 ilustra a representação esquemática do modelo. Os parâmetros de ajuste (também indicados na Figura 2.4) são, respectivamente:

$R_{p o l}$ e $\rho_{p o l}$, espessura e densidade eletrônica da cabeça polar;

$R_{\mathrm{CH}_{2}}$ e $\rho_{\mathrm{CH}_{2}}$, espessura e densidade eletrônica da região hidrofóbica contendo as cadeias $\mathrm{CH}_{2} \mathrm{e}$

$R_{C_{3} H_{3}}$ e $\rho_{C H_{3}}$ espessura e densidade eletrônica da região hidrofóbica contendo o grupo metil terminal $\mathrm{CH}_{3}$.

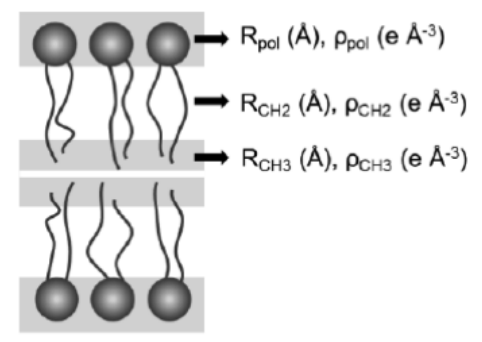

Figura 2.4: Representação esquemática do modelo de membrana. Figura extraída da referência [40].

Os ajustes do modelo às curvas experimentais foram feitas utilizando-se o programa GENFIT [16], [17], desenvolvido pelo Prof. Francesco Spinozzi. 


\section{Perfil de densidade eletrônica}

O perfil de densidade eletrônica ao longo do eixo z, perpendicular à interface lipídeoágua, foi calculado conforme descrito no artigo de Spinozzi e colaboradores [41]. Para tanto, considera-se uma variação suave entre os níveis adjacentes de densidade eletrônica (Figura 2.4. Tais transições são representadas pela função erro erf(z).

A expressão resultante para a densidade eletrônica ao longo do eixo z da bicamada lipídica, tomando como ponto zero o centro da bicamada, é dada por:

$$
\begin{aligned}
& \rho(z)=\rho_{0}+ \frac{1}{2}\left\{\left[\rho_{0}-\rho_{p o l}\right] \times\left[\operatorname{erf}\left(\frac{z-Z_{1}}{\sqrt{2}}\right)-\operatorname{erf}\left(\frac{z+Z_{1}}{\sqrt{2}}\right)\right]+\right. \\
&+\left[\rho_{p o l}-\rho_{C H_{2}}\right] \times\left[\operatorname{erf}\left(\frac{z-Z_{2}}{\sqrt{2}}\right)-\operatorname{erf}\left(\frac{z+Z_{2}}{\sqrt{2}}\right)\right]+ \\
&\left.+\left[\rho_{C H_{2}}-\rho_{C H_{3}}\right] \times\left[\operatorname{erf}\left(\frac{z-Z_{3}}{\sqrt{2}}\right)-\operatorname{erf}\left(\frac{z+Z_{3}}{\sqrt{2}}\right)\right]\right\}
\end{aligned}
$$

onde: $\mathrm{Z}_{1}=\mathrm{R}_{\text {pol }}+\mathrm{R}_{\mathrm{CH}_{2}}+\mathrm{R}_{\mathrm{CH}_{3}}$

$\mathrm{Z}_{2}=\mathrm{R}_{\mathrm{CH}_{2}}+\mathrm{R}_{\mathrm{CH}_{3}}$

$\mathrm{Z}_{3}=\mathrm{R}_{\mathrm{CH}_{3}}$ 


\subsection{Amostras}

Nesta parte do trabalho investigamos dois lipossomos compostos por DPPC (dipalmitoil fosfatidilcolina) na ausência e presença de cálcio; DPPC:DPPS (9:1) (dipalmitoil fosfatidilserina), na ausência e presença de cálcio. Além disso, foram analisados os proteolipossomos na ausência e presença de anexina $\mathrm{V}$ humana (A5) e proteína GPI-ancorada TNAP.

As estruturas químicas dos lipídios DPPC e DPPS são mostradas nas Figuras 2.5 e 2.6.<smiles>CCCCCCCCCCCCCCCCCCCCCCC(=O)OC[C@H](COP(=O)([O-])OCC[N+](C)(C)C)OC(=O)CCCCCCCCC</smiles>

Figura 2.5: Estrutura química do lipídio DPPC. Imagem extraída da referência [42].<smiles>CCCCCCCCCCCCCCCCCCCCCCCCC(=O)OC[C@H](COP(=O)([O-])OC[C@H]([NH3+])C(=O)[O-])OC(=O)[OH2+]</smiles>

Figura 2.6: Estrutura química do lipídio DPPS. Imagem extraída da referência [43].

A obtenção e purificação da A5, bem como a obtenção e cultivo das células expressando TNAP e a preparação dos lipossomos e proteolipossomos foram realizadas pela Dra. Maytê Bolean no laboratório do Prof. Dr. Pietro Ciancaglini (FFCLRP-USP).

\section{Preparação dos lipossomos}

Os lipídios DPPC e DPPS foram utilizados na preparação dos lipossomos constituídos de DPPC e DPPC:DPPS 10\% (fração molar), na presença e ausência de $2 \mathrm{mM}$ de cloreto de cálcio.

Para a preparação dos lipossomos, os lipídios foram dissolvidos em clorofórmio. A remoção do clorofórmio foi feita utilizando-se da passagem de um fluxo de nitrogênio pela 
solução. Os filmes formados nas paredes do tubo foram mantidos em vácuo por 1 hora. O filme lipídico formado foi ressuspenso em tampão Tris- $\mathrm{HCl} 50 \mathrm{mM}, \mathrm{pH} 7,5$, contendo $\mathrm{MgCl}_{2}$ $2 \mathrm{mM}$ e $2 \mathrm{mM}$ de cloreto de cálcio (para os casos onde este último estava presente), para se obter uma solução de concentração final de 1,5 mg/mL. Para comparar os lipossomos e proteolipossomos nas mesmas condições, o $\mathrm{MgCl}_{2}$, que é um cofator para a TNAP, foi adicionado ao tampão de todas as amostras. As soluções foram incubadas a $70^{\circ} \mathrm{C}$, por 1 hora, com agitações em vortex em intervalos de 10 minutos e extrusada utilizando-se o sistema de extrusão Liposofast (Sigma-Aldrich) e uma membrana de policarbonato de $100 \mathrm{~nm}$. As amostras foram estocadas a $4^{\circ} \mathrm{C}$ até o momento de utilização[35], [36].

\section{Preparação dos proteolipossomos}

Para preparação dos proteolipossomos da A5, os lipossomos foram incubados por 12 horas a $25^{\circ} \mathrm{C}$ com $0,2 \mathrm{mg} / \mathrm{mL}$ de $\mathrm{A} 5$ em tampão Tris- $\mathrm{HCl} 50 \mathrm{mM}$, pH 7,5, contendo $\mathrm{MgCl}_{2}$ $2 \mathrm{mM}$ e $2 \mathrm{mM}$ de cálcio (para os casos onde este último estava presente). Após incubação, a amostra foi ultracentrifugada a 100.000xg por 1 hora, a $4^{\circ} \mathrm{C}[36$.

A preparação dos proteolipossomos com A5 e TNAP foi feita incubando-se os lipossomos com a TNAP, a uma concentração de 0,02 mg/mL, em tampão Tris-HCl 50 mM, pH 7,5, contendo $\mathrm{MgCl}_{2} 2 \mathrm{mM} 2 \mathrm{mM}$ de cálcio (para os casos onde este último estava presente). A amostra foi homogeneizada e incubada a $25^{\circ} \mathrm{C}$, por $20 \mathrm{~h}$. Em seguida, a mistura foi ultracentrifugada a 100.000xg por $1 \mathrm{~h}$, a $4^{\circ} \mathrm{C}$. Os proteolipossomos formados foram ressuspensos em tampão Tris-HCl 50 mM, pH 7,5, contendo $\mathrm{MgCl}_{2} 2 \mathrm{mM}$ e $2 \mathrm{mM}$ de cloreto de cálcio (para os proteolipossomos na presença de cálcio).[36]. 


\subsection{Resultados e Discussão}

As Figuras 2.7. A a 2.7. C mostram as curvas de SAXS em escala arbitrária dos lipossomos e proteolipossomos estudados. Nas Figuras 2.8. A a 2.8. C são mostradas as mesmas curvas, porém em escala logarítmica, a fim de ressaltar as diferenças observadas na região de $q \leq 0,2 \AA^{-1}$.

Podemos observar nas Figuras 2.7. A e 2.8. A que os dados experimentais de espalhamento da bicamada lipídica de PC não apresentam alterações ao adicionar cálcio ao sistema. Assim, para uma melhor estatística, a análise foi feita utilizando a média dessas duas curvas experimentais. Por outro lado, a adição de cálcio à amostra de DPPC:DPPS (9:1), acarreta em uma intensidade ligeiramente inferior na região de $q \leq 0,2 \AA^{-1}$ com relação aos dados medidos para DPPC:DPPS (9:1) (Figuras 2.7.B e 2.8.B). A pequena diferença vista entre as curvas pode ser devido a uma pequena diferença na concentração da amostra extrusada. Considera-se esta possibilidade pois, como será visto mais a frente neste capítulo, esta diferença não é observada quando há a presença de A5.

Ao compararmos as curvas das membranas de DPPC:DPPS (9:1) e puras de DPPC, podemos observar nas Figuras 2.7. C e 2.8. C uma menor intensidade de espalhamento para a região compreendida entre $0,07 \AA^{-1} \leq q \leq 0,15 \AA^{-1}$ para a amostra de PC. Novamente, vale a pena ressaltar que talvez haja um ligeiro problema na concentração da amostra de DPPC:DPPS (9:1). 


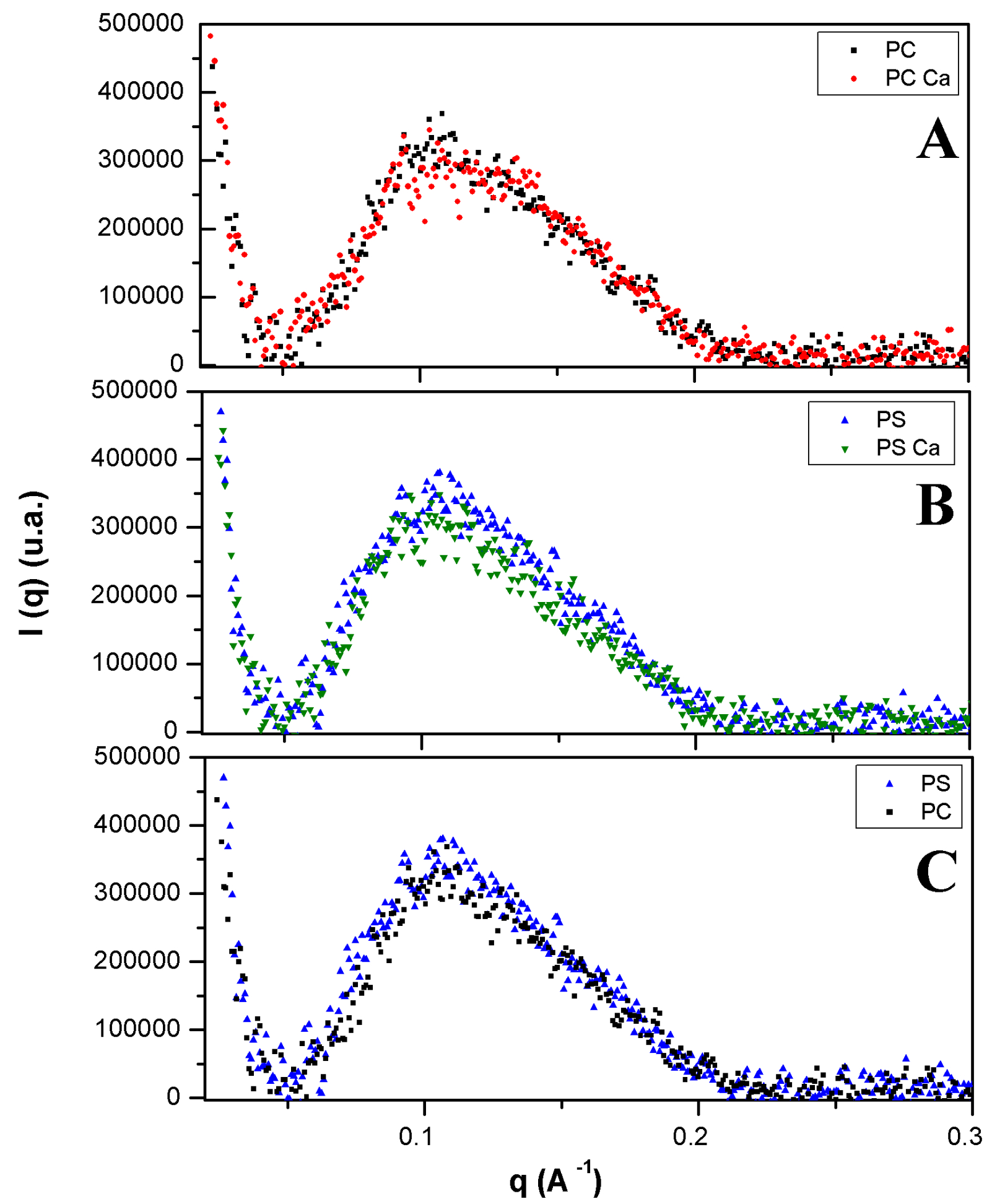

Figura 2.7: Comparação das curvas de SAXS (em escala linear) para os lipossomos compostos por: (A) DPPC, DPPC na presença de cálcio; (B) DPPC:DPPS (9:1), DPPC:DPPS (9:1) na presença de cálcio e (C) DPPC:DPPS (9:1) e DPPC. 


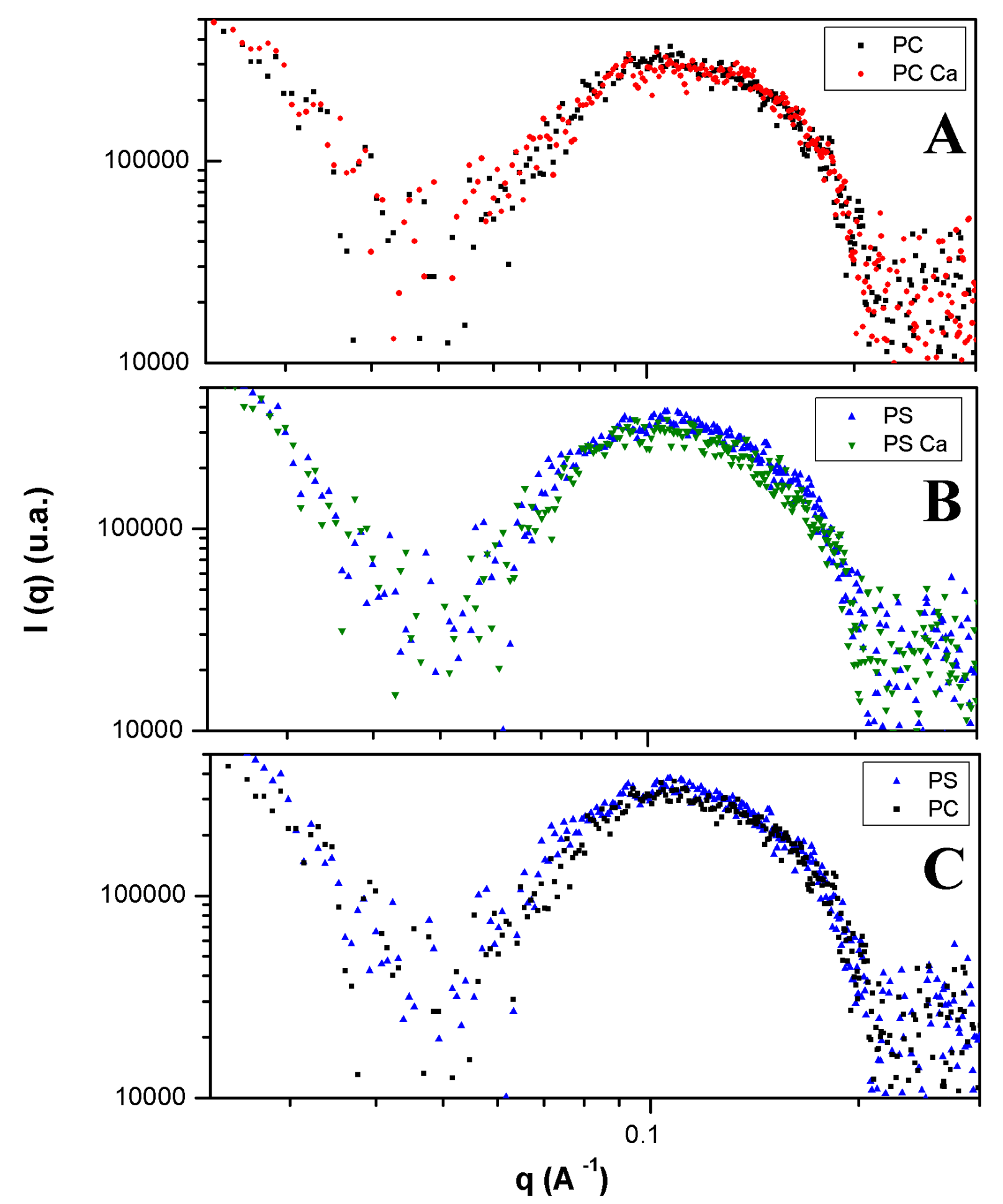

Figura 2.8: Comparação das curvas de SAXS (em escala log x log) para os lipossomos compostos por: (A) DPPC, DPPC na presença de cálcio; (B) DPPC:DPPS (9:1), DPPC:DPPS (9:1) na presença de cálcio e (C) DPPC:DPPS (9:1) e DPPC. 
Na Figura 2.9. A podem ser observadas todas as curvas de SAXS para os proteolipossomos contendo A5. De maneira equivalente aos lipossomos, a Figura 2.10. A mostra as curvas obtidas em escala logarítmica. Uma vez verificado que não há diferenças significativas entre os resultados para esses proteolipossomos, foi feita uma média de todas essas curvas experimentais. As Figuras 2.9. B e 2.10.B mostram a curva resultante, identificada na legenda como A5, tanto em escala linear quanto em escala logarítmica. Podemos observar que, nas membranas de DPPC e DPPC:DPPS (9:1), na presença e na ausência de cálcio, a curva de espalhamento é diferente que para a membrana na ausência de A5. 


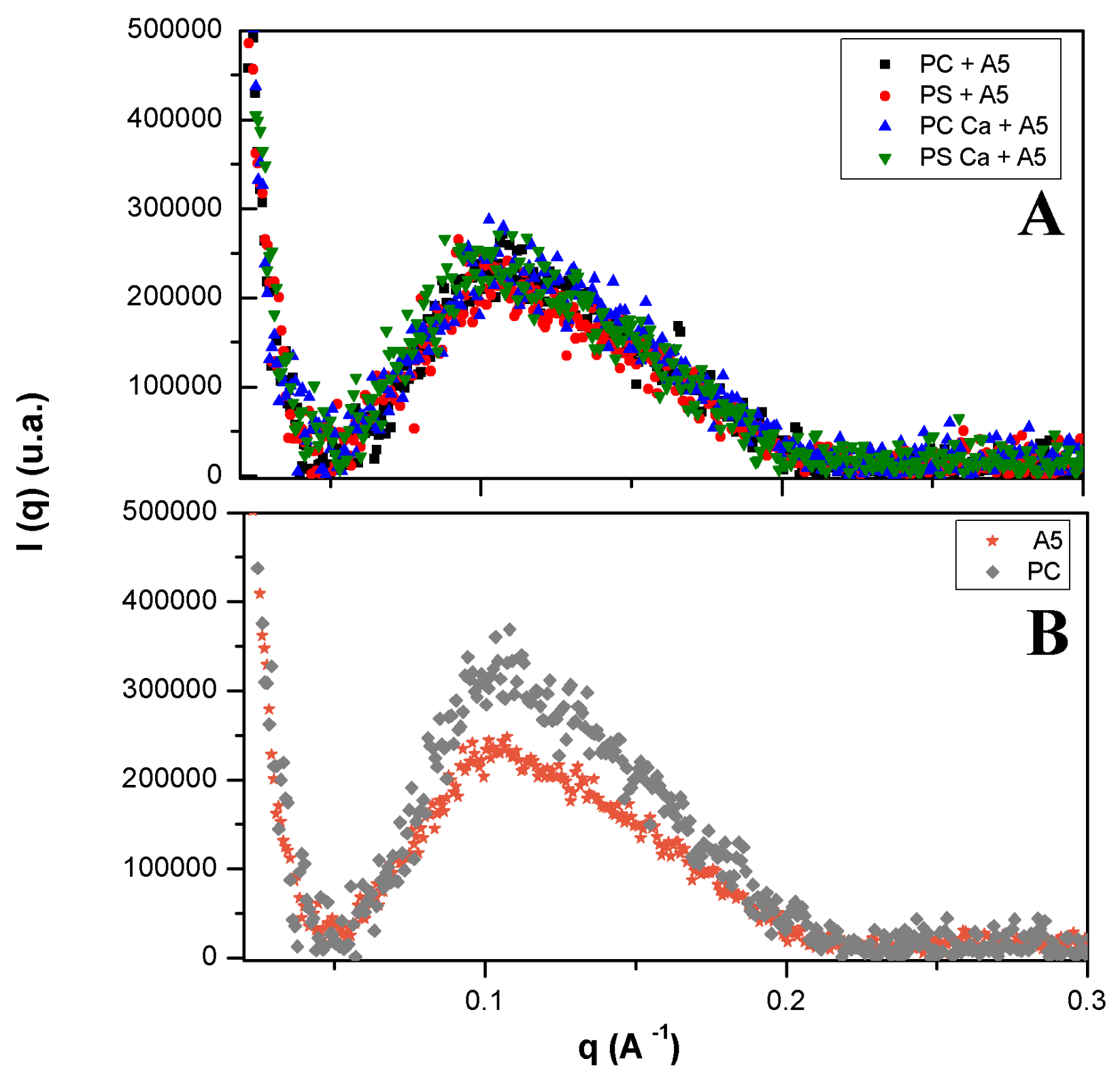

Figura 2.9: (A) Curvas de SAXS (em escala linear) para os proteolipossomos de A5 compostos por DPPC + A5, DPPC:DPPS (9:1) + A5, DPPC + A5 na presença de cálcio, DPPC:DPPS (9:1) + A5 na presença de cálcio. (B) Comparação das curvas de SAXS da curva média de todos os proteolipossomos contendo A5 com a curva do lipossomo de DPPC. 


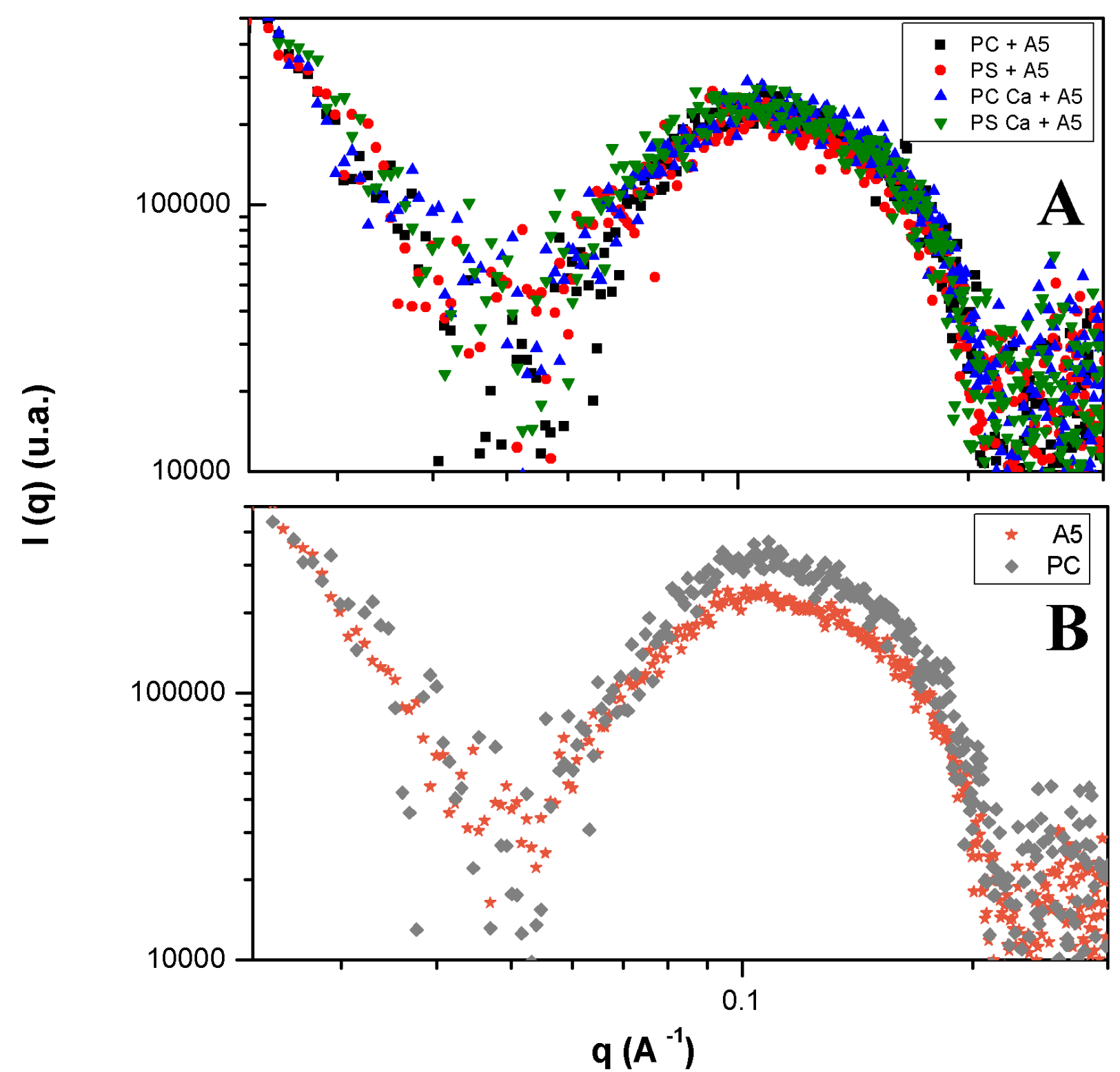

Figura 2.10: (A) Curvas de SAXS (em escala log x log) para os proteolipossomos de A5 compostos por DPPC + A5, DPPC:DPPS (9:1) + A5, DPPC + A5 na presença de cálcio, DPPC:DPPS (9:1) + A5 na presença de cálcio. (B) Comparação das curvas de SAXS da curva média de todos os proteolipossomos contendo A5 com a curva do lipossomo de DPPC. 
Podemos observar nas Figuras 2.11. A e 2.12. A (escalas linear e logarítmica, respectivamente) que, assim como para as amostras contendo A5, as curvas de SAXS para os proteolipossomos de A5 + TNAP também se sobrepõem. Mais ainda, é possível verificar nas Figuras 2.11.B e 2.12.B que as curvas médias obtidas para os proteolipossomos de A5 não apresentam diferenças com relação à curva média obtida para as amostras de proteolipossomos na presença de TNAP + A5. 


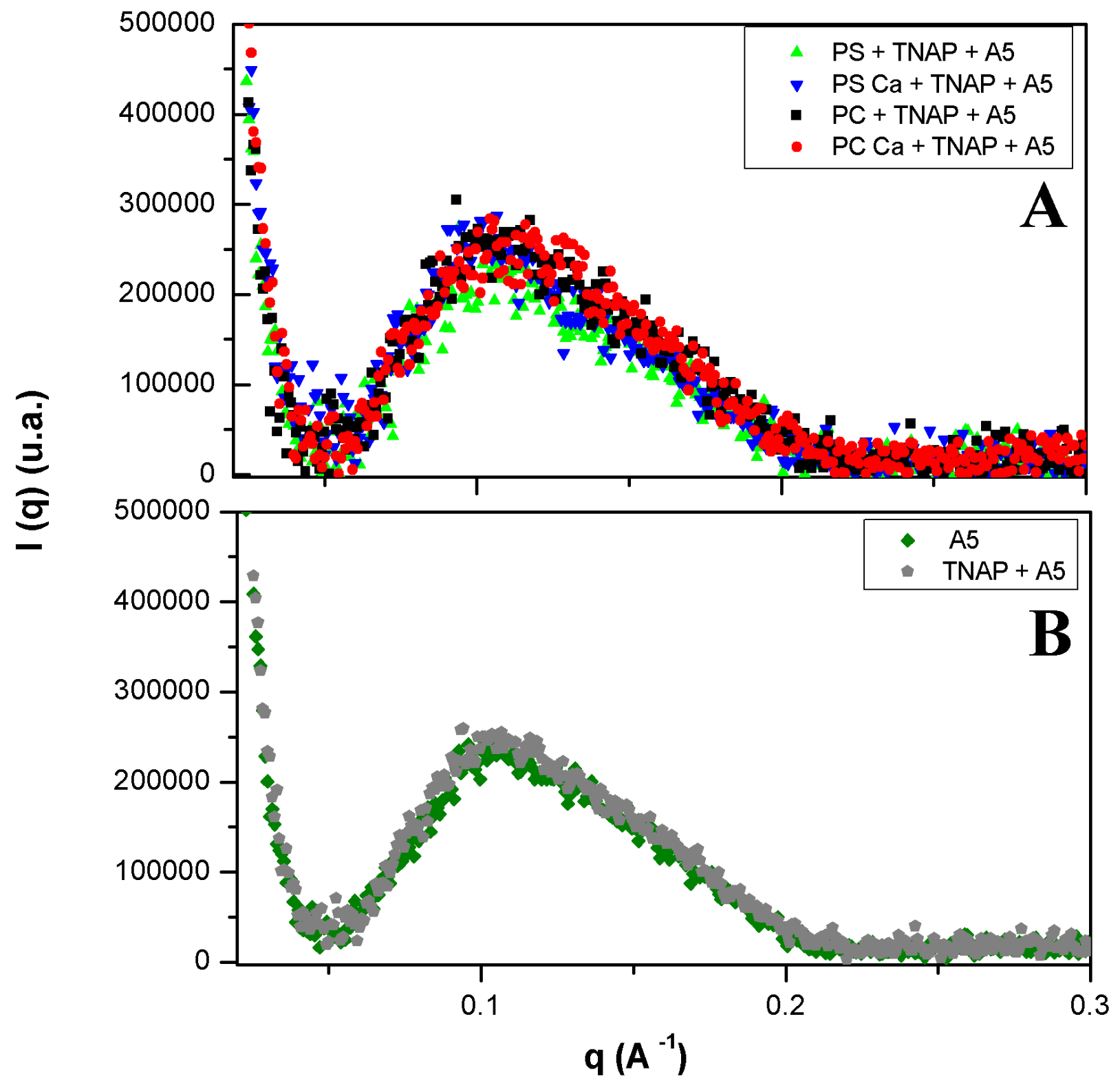

Figura 2.11: (A) Curvas de SAXS (em escala linear) para os proteolipossomos contendo TNAP + A5 compostos por DPPC + A5 + TNAP, DPPC:DPPS (9:1) + A5 + TNAP, DPPC + A5 + TNAP na presença de cálcio, DPPC:DPPS (9:1) + A5 + TNAP na presença de cálcio. (B) Comparação das curvas de SAXS da curva média de todos os proteolipossomos de TNAP + A5 com a curva média de todos os proteolipossomos de A5. 


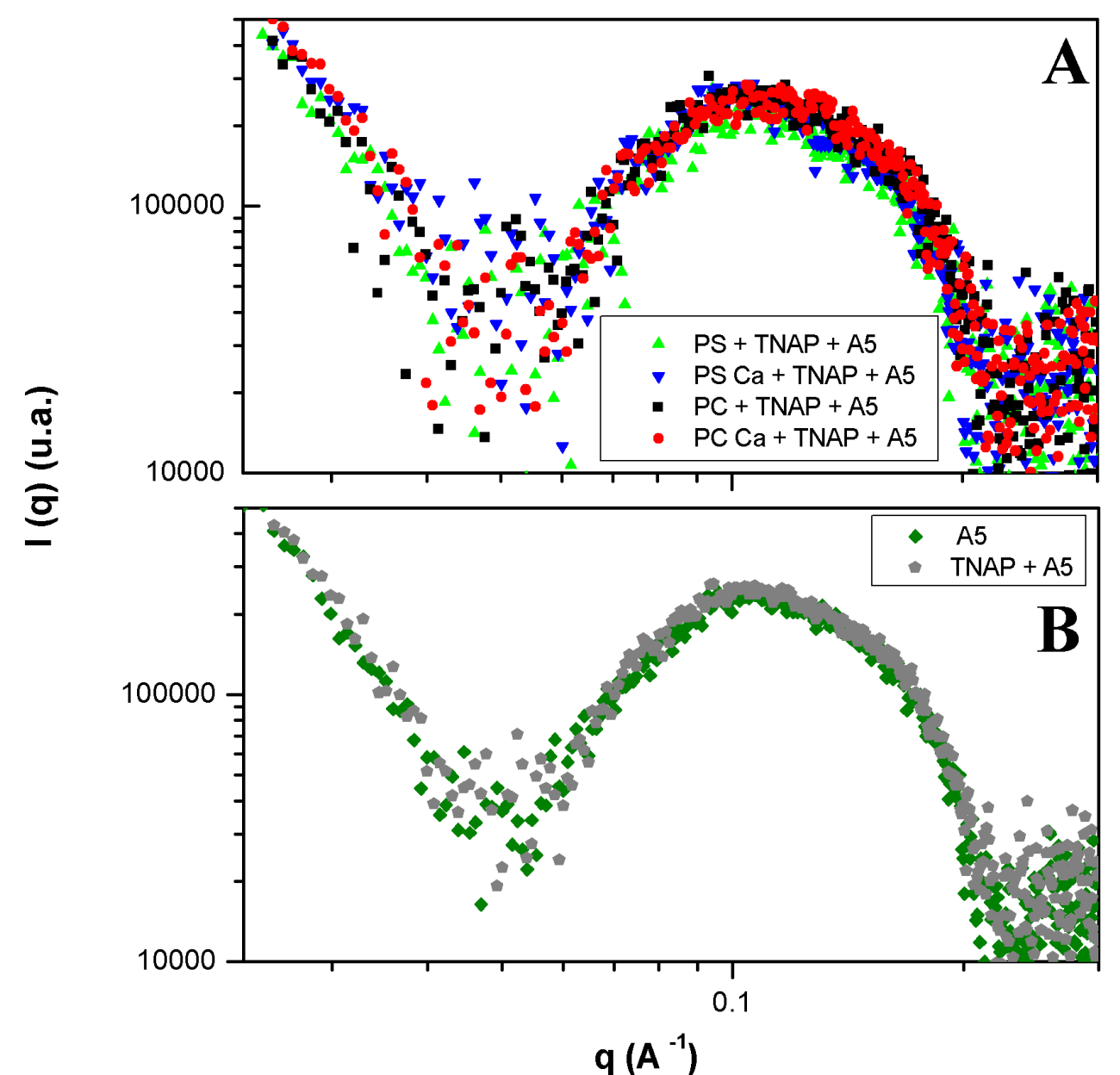

Figura 2.12: (A) Curvas de SAXS (em escala log x log) para os proteolipossomos contendo $\mathrm{TNAP}+\mathrm{A} 5$ compostos por DPPC + A5 + TNAP, DPPC:DPPS (9:1) + A5 + TNAP, DPPC + A5 + TNAP na presença de cálcio, DPPC:DPPS (9:1) + A5 + TNAP na presença de cálcio. (B) Comparação das curvas de SAXS da curva média de todos os proteolipossomos de TNAP + A5 com a curva média de todos os proteolipossomos de A5. 


\subsection{Análise de dados com modelo de membranas}

Tendo em vista os resultados apresentados anteriormente, com o intuito de determinar as diferenças estruturais entre os lipossomos e proteolipossomos estudados, propomos o ajuste das curvas experimentais de SAXS utilizando a composição de dois modelos: um modelo de membrana unilamelar e outro, multilamelar. A inclusão do modelo referente à multilamela se fez necessária após a execução de ajustes insatisfatórios utilizando apenas o modelo unilamelar. Além dos modelos citados, foi necessária a inclusão de uma intensidade de fundo constante.

Como exemplo de ajuste da soma dos dois modelos (lamela e multilamela) aos dados experimentais, a Figura 2.13 apresenta a curva experimental para a bicamada lipídica composta de DPPC:DPPS (9:1) na presença de cálcio. A linha contínua em preto indica o ajuste aos dados experimentais da curva utilizando a composição dos dois modelos e o fundo. Por sua vez, as linhas azul e verde indicam cada modelo isoladamente. Podemos perceber que o modelo referente à unilamela (em azul) somado ao fundo (linha tracejada em preto) ajustaria de maneira satisfatória os dados experimentais, salvo as regiões compreendidas entre $0,08 \leq q \leq 0,1 \AA^{-1}$ e $0,18 \leq q \leq 0,2 \AA^{-1}$. Para o refinamento do ajuste nessas regiões, é necessária a contribuição do modelo multilamelar (curva em verde).

As curvas experimentais e melhores ajustes estão apresentados nas Figuras 2.14 e 2.15. para os lipossomos e proteolipossomos, respectivamente. Na Tabela 2.1 estão dispostos todos os parâmetros obtidos a partir dos ajustes das curvas experimentais.

Apesar das amostras terem sido extrusadas, multilamelas com 3 bicamadas coexistem em menor porcentagem com relação às bicamadas unilamelares, sendo da ordem de $10 \%$ para os lipossomos de DPPC, DPPC na presença de cálcio e DPPC:DPPS (9:1). Para o lipossomo de DPPC:DPPS (9:1) na presença de cálcio, a porcentagem de multilamelas corresponde a aproximadamente $12 \%$. A porcentagem de unilamelas nos proteolipossomos apresentou valores semelhantes ao observado para os lipossomos de DPPC e DPPC:DPPS (9:1). Para todas as amostras, o espaçamento entre as bicamadas lipídicas é de $68 \AA$. O parâmetro de Caillé, que representa as flutuações e a flexibilidade das multilamelas, não sofreu alterações com a inserção de A5 e A5 + TNAP no sistema. 


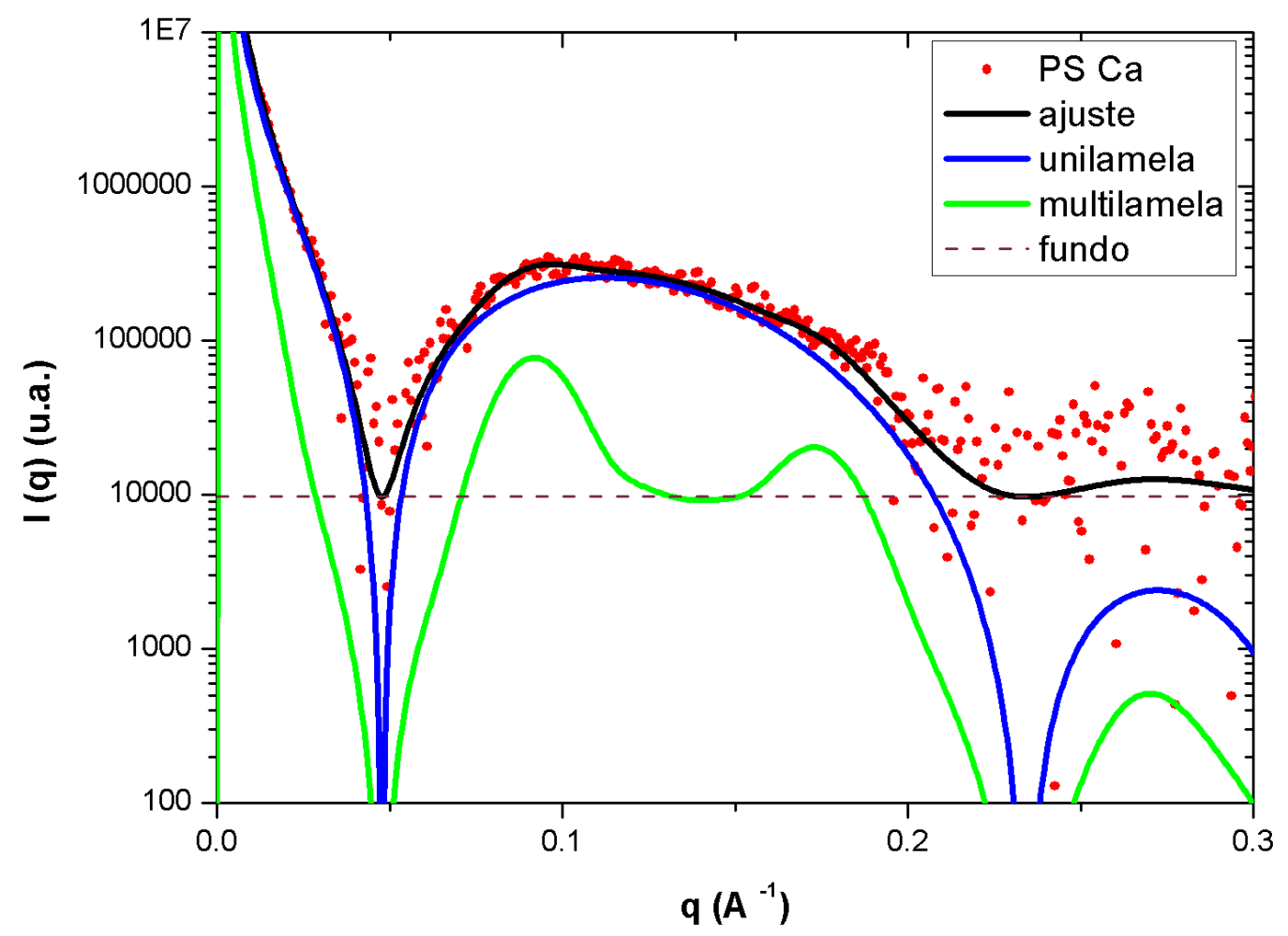

Figura 2.13: Exemplo de ajuste da curva de SAXS para o lipossomo de DPPC:DPPS (9:1) na presença de cálcio, utilizando os modelos de bicamada lipídica unilamelar e multilamelar, com contribuições de 88,6\% e 11,4\%, respectivamente (Tabela 2.1). 


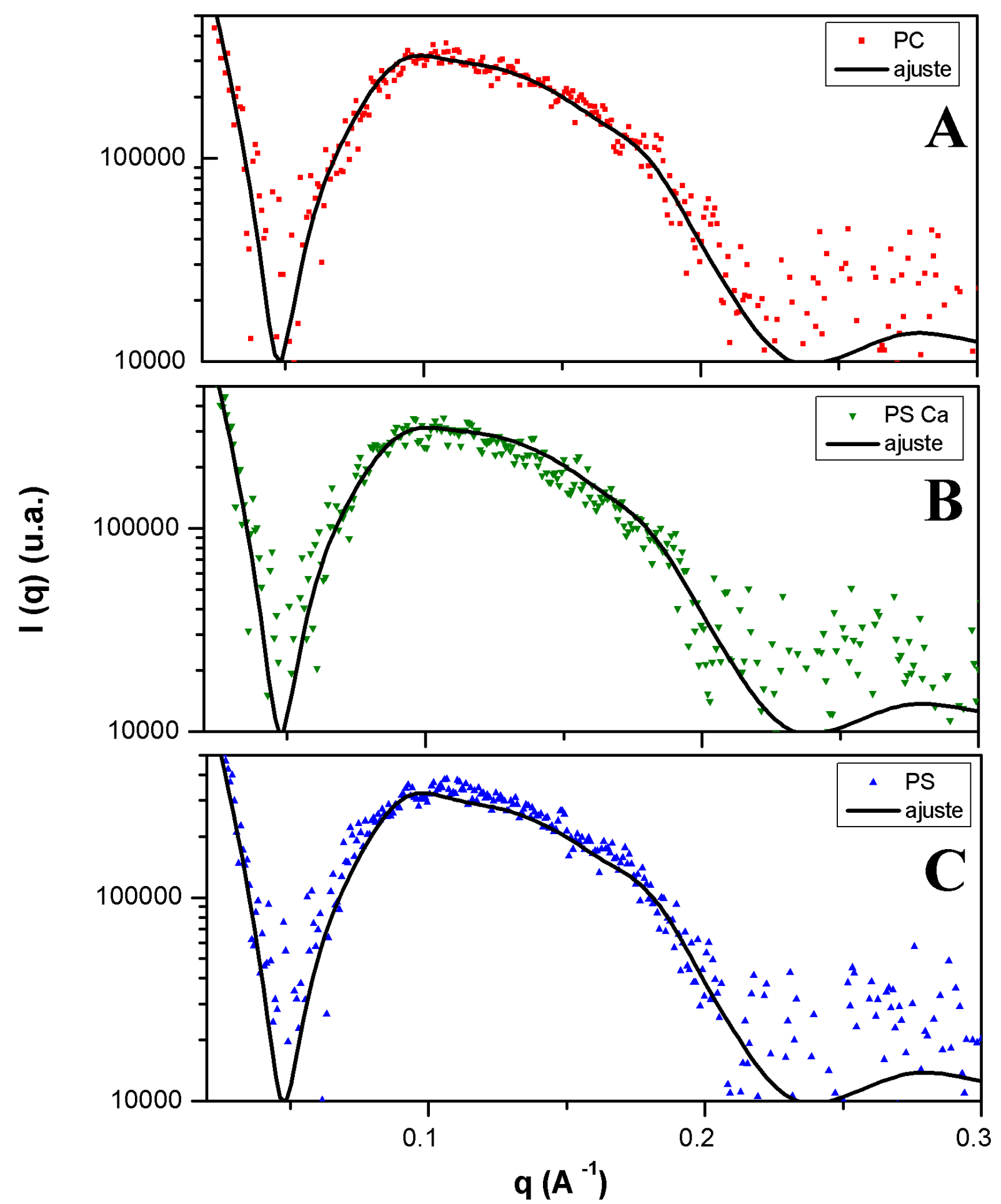

Figura 2.14: Melhores ajustes das curvas de SAXS para os lipossomos compostos por: (A) DPPC; (B) DPPC:DPPS (9:1) na presença de cálcio (C) DPPC:DPPS (9:1). 


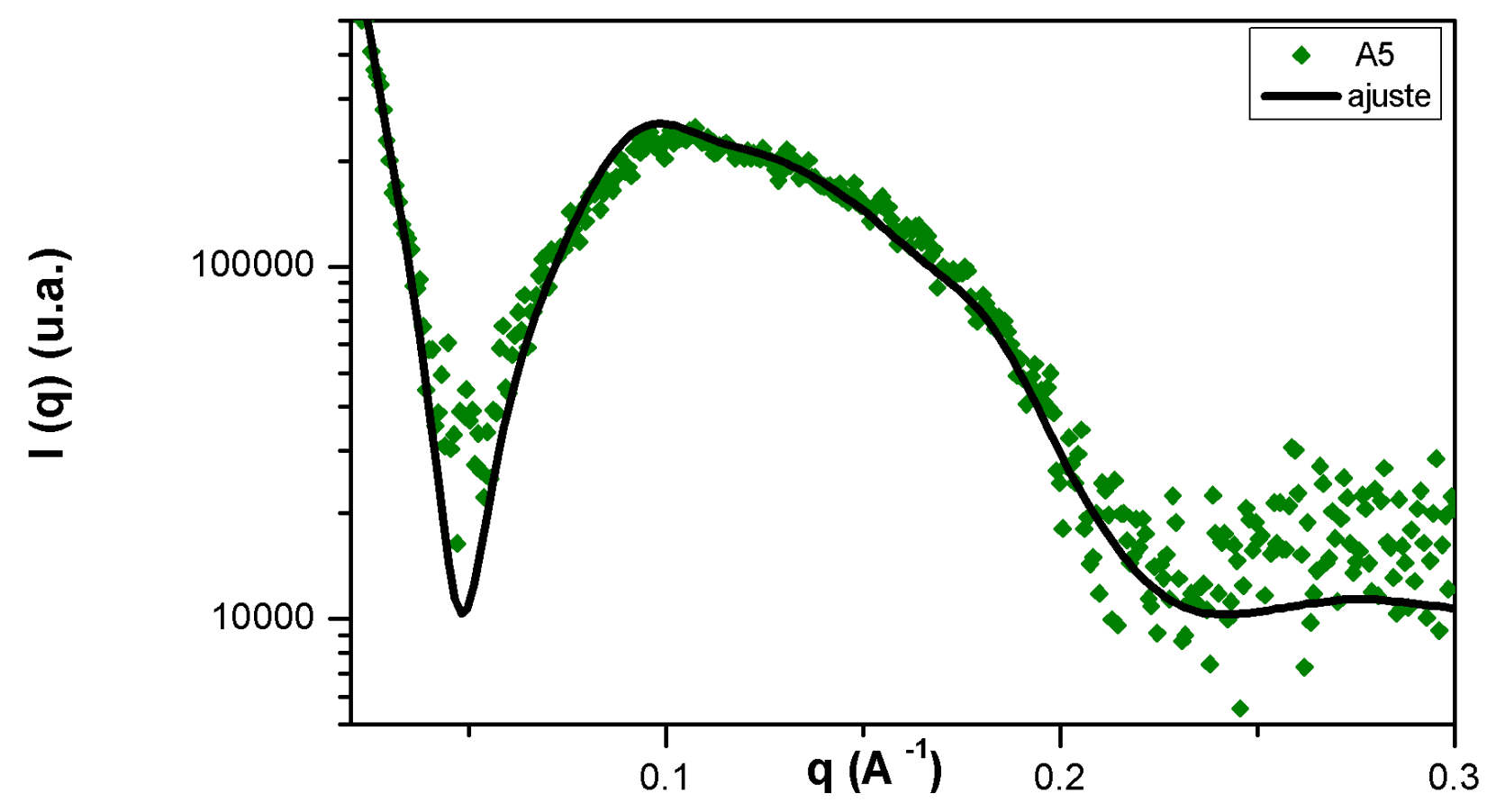

Figura 2.15: Melhor ajuste da curva média de SAXS para os proteolipossomos de A5 (curva média de DPPC + A5, DPPC:DPPS (9:1) + A5, DPPC + A5 na presença de cálcio, DPPC:DPPS (9:1) + A5 na presença de cálcio, DPPC + A5 + TNAP, DPPC:DPPS (9:1) + A5 + TNAP, DPPC + A5 + TNAP na presença de cálcio e DPPC:DPPS (9:1) + A5 + TNAP na presença de cálcio). 
Tabela 2.1: Parâmetros dos ajustes experimentais (item 2.3.1 para lipossomos e proteolipossomos estudados.

\begin{tabular}{c|ccc|c}
\hline & \multicolumn{3}{|c|}{ Lipossomos } & Proteolipossomos \\
\hline & PC & PS & PS e Ca & A $5^{(*)}$ \\
& PC e Ca & TNAP $\left.+\mathrm{A} 5^{(* *}\right)$ \\
\hline $\mathrm{R}_{\text {pol }}(\AA)$ & \multicolumn{3}{|c|}{$13(1)$} & $14(1)$ \\
$\mathrm{R}_{C H_{2}}(\AA)$ & & $10,9(3)$ & $10,7(5)$ \\
$\mathrm{R}_{C H_{3}}(\AA)$ & & $3,5(1)$ & $3,5(1)$ \\
$\%$ de unilamela & $93,0(5) \%$ & $90,9(4) \%$ & $88,6(2) \%$ & $91,2(2)$ \\
$\rho_{\text {pol }}\left(e^{-} / \AA^{3}\right)$ & & $0,42(1)$ & $0,40(1)$ \\
$\rho_{C H_{2}}\left(e^{-} / \AA^{3}\right)$ & & $0,31(1)$ & $0,32(1)$ \\
$\rho_{C H_{3}}\left(e^{-} / \AA^{3}\right)$ & & $0,21(1)$ & $0,22(1)$ \\
$\mathrm{N}$ & & $3(1)$ & $3(1)$ \\
$\mathrm{d}(\AA)$ & & $68(2)$ & $68(2)$ \\
caille & $0,04(1)$ & $0,04(1)$ & $0,05(1)$ & $0,040(1)$ \\
fundo (u.a.) & & $9713(130)$ & $10060(250)$ \\
\hline
\end{tabular}

(*) DPPC + A5, DPPC:DPPS (9:1) + A5, DPPC + A5 na presença de cálcio, DPPC:DPPS (9:1) + A5 na presença de cálcio.

$(* *)$ DPPC + A $5+$ TNAP, DPPC:DPPS $(9: 1)+$ A $5+$ TNAP, DPPC + A $5+$ TNAP na presença de cálcio, DPPC:DPPS (9:1) + A5 + TNAP na presença de cálcio. 
Os perfis de densidade eletrônica foram calculados conforme descritos na Seção 2.3.1. utilizando os parâmetros mostrados na Tabela 2.1. Na Figura 2.16 estão representados os perfis de densidade eletrônica dos lipossomos, assim como dos proteolipossomos contendo A5. Verifica-se que há a diminuição da densidade eletrônica para a região referente à cabeça polar nos proteolipossomos de A5 e A5 + TNAP. Não há alterações significativas no interior da bicamada lipídica levando em conta a incerteza avaliada nos parâmetros estruturais.

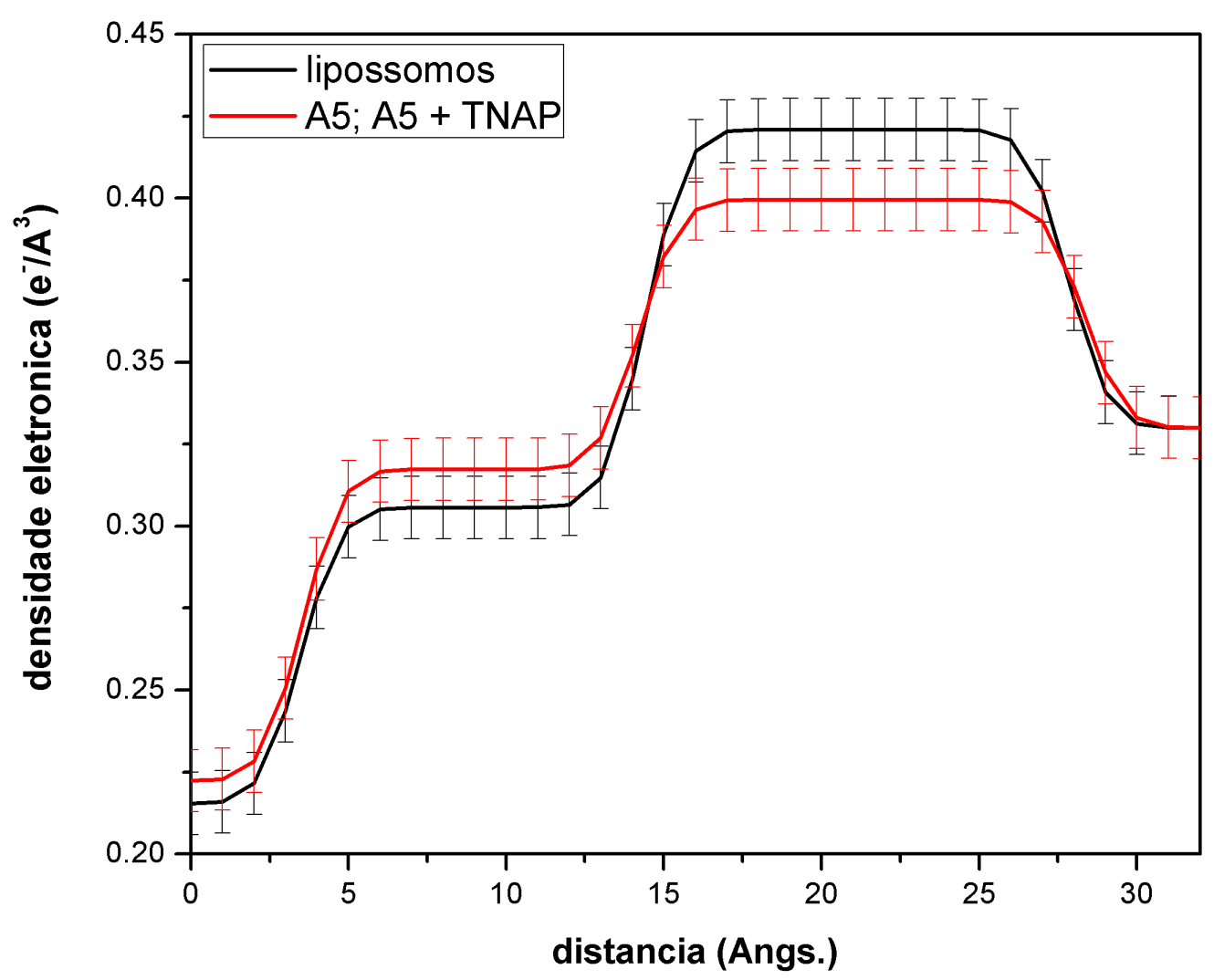

Figura 2.16: Comparação do perfil de densidade eletrônica para os lipossomos com relação aos proteolipossomos de A5 e A5 + TNAP. 
Bolean e colaboradores [36] mostraram que a A5 foi capaz de mediar o fluxo de $\mathrm{Ca}^{2}+$ para dentro de vesículas de DPPC e DPPC:DPPS 10\% em condições fisiológicas de concentrações de cálcio (aproximadamente $2 \mathrm{mM}$, mesma concentração utilizada no presente estudo). Este processo também não foi afetado pela presença da TNAP nos proteolipossomos. Foi demonstrado anteriormente [44] que a presença de lipídeos carregados e colesterol [45] em sistemas miméticos, ou proteolipossomos com composição lipídica mais complexa [35] pode afetar as propriedades catalíticas de ancoramento da TNAP ancorada.

Na presente tese, demonstramos não haver diferenças estruturais entre lipossomos compostos por apenas DPPC com relação aqueles que contém 10\% de DPPS. A presença de 2 mM de cálcio no ambiente externo dos lipossomos não altera as características estruturais da membrana. Por outro lado, a incorporação de A5 nos proteolipossomos estudados impacta em um decréscimo de densidade eletrônica na região polar da membrana, provavelmente devido a formação de poros [41], [46], [32]. Nanoporos são previstos na própria estrutura da anexina V (Figura 2.1) para a passagem de cálcio. Entretanto, neste estágio do trabalho não somos capazes de identificar apenas com dados de SAXS se a A5 pode estar inserida na membrana formando trímeros, hexâmeros e/ou outros oligômeros, conforme reportado na literatura [30], 31, e ainda motivo de debate. A presença de TNAP, em concentração muito menor que a da A5, não alterou os perfis de densidade eletrônica em relação aos proteolipossomos contendo apenas A5.

\subsection{Conclusão}

Os resultados de SAXS indicam que a principal diferença entre os lipossomos e os proteolipossomos está no decréscimo da densidade eletrônica da região polar da membrana, sem alterar significativamente a espessura desta região. A inserção da proteína não altera os parâmetros estruturais da região hidrofóbica da bicamada lipídica. Não há diferenças, pelo ponto de vista da análise de SAXS, entre os resultados obtidos para os proteolipossomos de A5 e os de A5 na presença de TNAP. A concentração da TNAP é aproximadamente 10 vezes menor que a A5 e, portanto, é compreensível que não foram observadas alterações nas propriedades estruturais da membrana com a adição de TNAP no sistema.

Como perspectiva futura, pretende-se determinar o tamanho do poro analisando as curvas de SAXS com o modelo que considera a formação de poros em membranas desenvolvido recentemente pela Prof. ${ }^{a}$ Rosangela Itri em colaboração com o Prof. Francesco Spinozzi. 



\section{Capítulo 3}

\section{Estabilidade térmica da albumina soro bo- vina (BSA) frente a dois agentes desnatu- rantes: SDS e uréia}

\subsection{Introdução}

A albumina de soro consiste em uma proteína globular sintetizada pelo fígado de mamíferos e representa $60 \%$ de todas as proteínas globulares no plasma sanguíneo [47]. Sua função está associada com o transporte de diversas moléculas pequenas tais como ácidos graxos, metais, aminoácidos e diversos componentes farmacêuticos [48], 49], [50] e [51]. BSA é composta por 585 aminoácidos e sua estrutura secundária é constituida por $67 \%$ de $\alpha$-hélices. A estrutura cristalográfica da BSA, código pdb 4F5S[52], é mostrada na Figura 3.1.

A interação de proteínas globulares, especialmente a albumina de soro bovina (BSA), com surfactantes, em particular dodecil sulfato de sódio (SDS) tem sido extensamente reportado com o objetivo de entender como a ligação do surfactante afeta a estrutura da proteína e suas funções [53]. A estrutura química do SDS pode ser vista na Figura 3.2. Dois intervalos de concentrações do surfactante estão associadas com diferentes efeitos na interação com a proteína: em concentrações mais baixas a ligação que ocorre em sítios de alta energia específicos na proteína, com as interações sendo em geral de natureza eletrostática ou hidrofóbica. Para concentrações maiores, acima da concentração micelar crítica (cmc), a ligação ocorre devido a interações de ligante cooperativas[53]. 


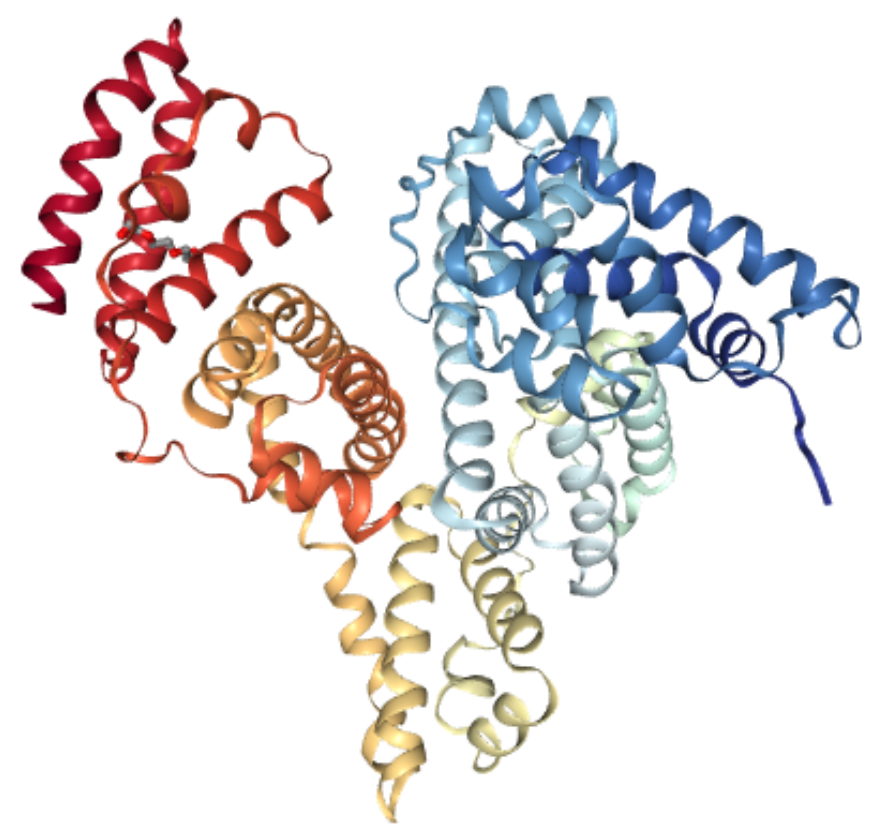

Figura 3.1: Estrutura cristalográfica da BSA [52]. Imagem gerada utilizzando o NGL Viewer[28], [29].

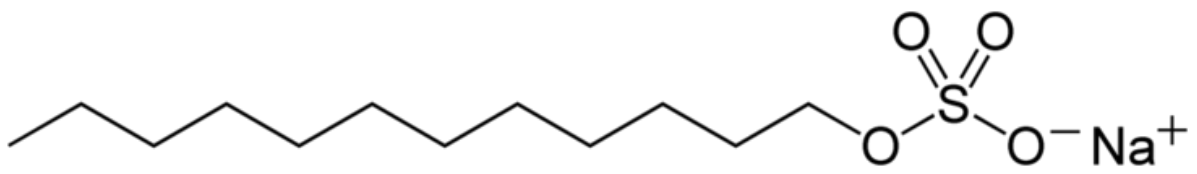

Figura 3.2: Estrutura química do SDS. Imagem extraída da referência [54].

O grupo de pesquisa da Profa. Rosangela itri vem estudando as interações da soro albumina com surfactantes iônicos. No estudo sistemático da interação da BSA com SDS em pH 5.4 foi observado que, para concentrações abaixo da concentração de agregação crítica de $2.2 \mathrm{mM}$, a conformação da proteína permanece inalterada. Entretanto, a $5 \mathrm{mM}$ de SDS, tanto o raio de giro da proteína quanto a dimensão máxima aumentam, refletindo no começo do processo de desenovelamento. Ainda, para concentrações acima de $10 \mathrm{mM}$ há a formação de agregados do tipo micela. As curvas de SAXS foram satisfatoriamente descritas pelo 
modelo de "colar de pérolas" [55]. Desta maneira, os agregados micelares são aleatoriamente distribuídos ao longo da cadeia e crescem em tamanho, mudando de uma forma esférica em concentração igual a $10 \mathrm{mM}$ de SDS para uma forma elipsoidal (com anisotropia pequena) em concentração igual a $50 \mathrm{mM}$ de SDS. Para concentrações acima de $50 \mathrm{mM}$ as micelas param de crescer, permanecendo em uma forma elipsoidal. Foi observado um aumento nos tamanhos das micelas concomitante com a diminuição na densidade eletrônica da cabeça polar ao aumentar-se a concentração de SDS[55].

De maneira interessante, estudos recentes vem demonstrando que a adição de SDS pode induzir a formação de agregados proteicos tipo amilóides em algumas proteínas parcialmente desenoveladas, incluindo a BSA[56]. É bem conhecido que a temperatura de desenovelamento da BSA é de aproximadamente $60^{\circ} \mathrm{C}$ [57], acima da temperatura fisiológica. Neste capítulo daremos ênfase no estudo da estabilidade térmica da BSA frente a ação de dois agentes desnaturantes, SDS e uréia. A estrutura química da uréia pode ser vista na Figura 3.3 .

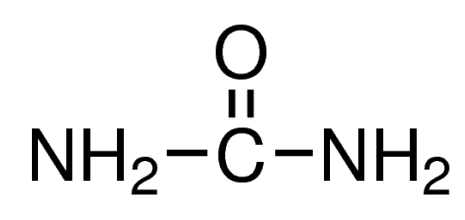

Figura 3.3: Estrutura química da uréia. Imagem extraída da referência [58]. 


\subsection{Objetivos}

\subsubsection{Geral}

Nesse trabalho utilizaremos a técnica de espalhamento de raios-X a baixos ângulos para estudar o efeito combinado de dois agentes desnaturantes, surfactante dodecil sulfato de sódio (SDS) e uréia, na conformação e agregação da BSA a pH 7, com variação de temperatura.

\subsubsection{Específicos}

- Verificar se o modelo de colar de pérolas pode ser aplicado para a proteína parcialmente desenovelada por uréia com adição de SDS.

- Investigar por SAXS o efeito de SDS a 1 mM, 3 mM, 6 mM, 10 mM, 30 mM, $50 \mathrm{mM}$ e $80 \mathrm{mM}$ na conformação de $\mathrm{BSA}$, a pH 7.0 e temperaturas iguais a $23^{\circ} \mathrm{C}, 30^{\circ} \mathrm{C}, 40^{\circ} \mathrm{C}$ e $50^{\circ} \mathrm{C}$, sem a presença de uréia.

- Investigar por SAXS o efeito de SDS a $1 \mathrm{mM}, 3 \mathrm{mM}, 6 \mathrm{mM}, 10 \mathrm{mM}, 30 \mathrm{mM}$ na conformação de $\mathrm{BSA}$, a pH 7.0 e temperaturas iguais a $23^{\circ} \mathrm{C}, 30^{\circ} \mathrm{C}, 40^{\circ} \mathrm{C}$ e $50^{\circ} \mathrm{C}$, na presença de $3 \mathrm{M}$ de uréia.

- Investigar por SAXS o efeito de SDS a $1 \mathrm{mM}, 3 \mathrm{mM}, 6 \mathrm{mM}, 10 \mathrm{mM}, 30 \mathrm{mM}$ na conformação de BSA, a pH 7.0 e temperaturas iguais a $23^{\circ} \mathrm{C}, 30^{\circ} \mathrm{C}, 40^{\circ} \mathrm{C}$ e $50^{\circ} \mathrm{C}$, na presença de $8 \mathrm{M}$ de uréia. 


\subsection{SAXS no Laboratório Nacional de Luz Síncrotron (LNLS)}

Os dados experimentais de espalhamento de raio-X a baixos ângulos (SAXS) foram obtidos utilizando a linha de SAXS1 do Laboratório Nacional de Luz Síncroton (LNLS). Cada uma das curvas apresentadas é o resultado de uma tomada de dados com tempo de aquisição de 100 segundos. Apesar da escala arbitrária, todos os dados experimentais foram medidos na mesma campanha, ou seja, mesmo dia e condições experimentais. Desta forma, a constante experimental é a mesma para todas as curvas apresentadas.

O intervalo do vetor de espalhamento utilizado foi: $0,0115 \leq q \leq 0,4219 \AA^{-1}$. Sendo a dimensão máxima medida pela técnica dada por [15]:

$$
D_{\text {máx }}=\frac{\pi}{q_{\min }}=\frac{\pi}{0,0115} \approx 273 \AA
$$

\subsection{Representação de Kratky}

A representação de Kratky consiste do gráfico de $q^{2} I(q)$ em função de $q$ [15]. Esta maneira de apresentar os dados experimentais de SAXS se mostra útil para caracterizar a conformação de uma dada proteína, permitindo diferenciar entre proteínas compactas e globulares de estados desenovelados. A forma da curva de SAXS de uma proteína globular na representação de Kratky é caracterizada pela presen;ca de um pico largo na forma de sino, cujo valor máximo depende do tamanho máximo médio da proteína. Ao assumir uma forma completamente desenovelada, a curva de SAXS nesta representação não possui mais o pico na forma de sino e apresenta um aumento contínuo em função de $q[1]$. 


\subsection{Análises modelo-dependentes}

As análises modelo-dependentes das curvas de SAXS foram feitas utilizando-se o programa GENFIT [16]. Cada um dos modelos utilizados estão detalhados nos itens a seguir.

\subsubsection{Elipsoide de Revolução}

Para representar as micelas de SDS foi utilizado o modelo de um elipsoide de duas camadas de densidades eletrônicas diferentes, sem nenhuma orientação preferencial. O fator de forma pode ser escrito como 59 :

$$
P(q)=\int_{0}^{\pi / 2}\left[\left(\rho_{\text {par }}-\rho_{\text {pol }}\right) V_{1} \Phi\left(q R_{1} \Theta_{1}(\psi)\right)+\left(\rho_{\text {pol }}-\rho_{0}\right) V_{2} \Phi\left(q R_{2} \Theta_{2}(\psi)\right)\right]^{2} \cos \psi \mathrm{d} \psi
$$

Sendo:

$$
\begin{array}{r}
\Phi(\alpha)=3 \frac{\operatorname{sen} \alpha-\alpha \cos \alpha}{\alpha^{3}} \\
\Theta_{1}(\psi)=\sqrt{\cos ^{2} \psi+\nu^{2} \operatorname{sen}^{2} \psi} \\
\Theta_{2}(\psi)=\sqrt{\cos ^{2} \psi+\nu_{\text {total }}^{2} \operatorname{sen}^{2} \psi}
\end{array}
$$

onde o menor semi-eixo do elipsoide prolato $R_{\text {par }}$ com densidade da região interna (hidrofóbica) fixada em $\rho_{\text {par }}=0,275 e / \AA^{3}$ e volume $V_{1}$. A anisotropia $\nu$ corresponde a razão entre o maior e o menor semieixo $\nu_{\text {total }}=\left(\nu R_{1}+\sigma_{\text {pol }}\right) / R_{2}$ sendo $\sigma_{\text {pol }}$ a espesura da camada externa polar do elipsoide (região hidrofílica), $R_{2}=R_{1}+\sigma ; V_{2}$ volume total do elipsoide e $\rho_{0}=0,334 e / \AA^{3}$ a densidade do solvente. 


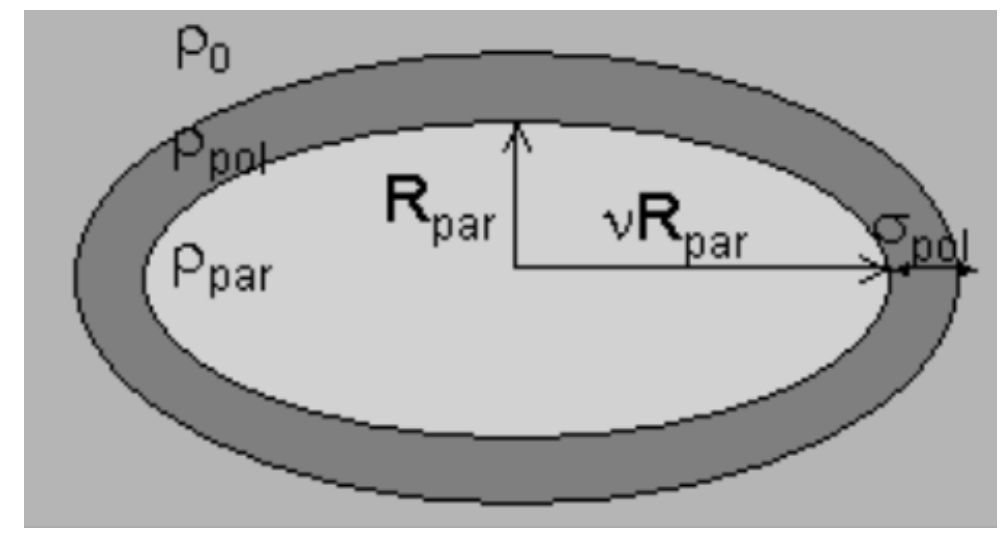

Figura 3.4: Representação esquemática do elipsoide prolato de revolução com dois níveis de densidade eletrônica diferentes em relação ao solvente $\left(\rho_{0}\right)$ utilizada para descrever a micela de SDS. Figura extraída da referência [59]. 


\subsubsection{Colar de pérolas}

O modelo de colar de pérolas representa micelas aleatoriamente distribuidas ao longo de uma proteína (cadeia polipeptídica) parcialmente ou totalmente desenovelada, tal que:

$$
I(q)=k n_{p} P(q) S(q)
$$

onde $k$ é uma constante experimental relacionada ao arranjo experimental utilizado e $n_{p}$ é a densidade numérica das partículas. O fator de forma $P(q)$ é descrito pelo elipsoide, conforme descrito na Seção 3.5.1. A função $S(q)$ é descrita pelo modelo fractal [60]:

$$
S(q)=1+\frac{1}{(q R)^{d}} \frac{d \Gamma(d-1)}{\left(1+(q \xi)^{-2}\right)^{(d-1) / 2}} \times \operatorname{sen}\left((d-1) t g^{-1}(q \xi)\right)
$$

onde $\Gamma(x)$ é a função gama do argumento $x, \xi$, a distância característica entre micelas adjacentes, a dimensão fractal $d$ diz respeito a quão compacta está a proteína. A dimensão fractal neste caso pode variar de $d=1$, indicando que as micelas estão ligadas a proteína em um estado mais desenovelada, a $d=3$, correspondendo a uma estrutura mias compacta. A Figura 3.5 mostra uma representação esquemática do modelo61.

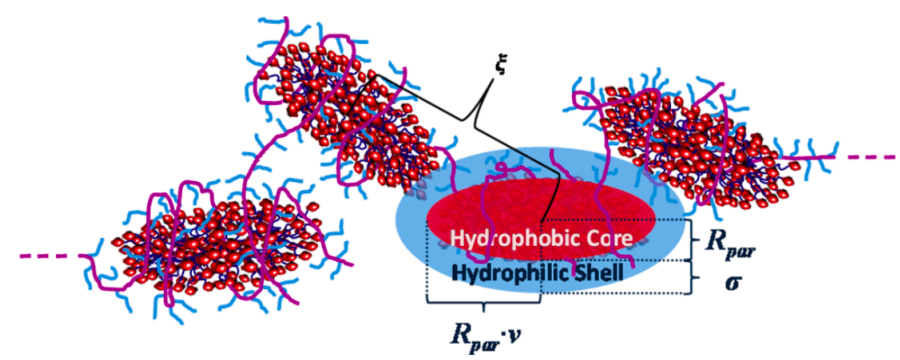

Figura 3.5: Representação esquemática do modelo de colar de pérolas. Figura extraída da referência [61].

\subsection{Amostras}

Foram investigadas amostras de BSA a $10 \mathrm{mg} / \mathrm{mL}(150 \mu M), \mathrm{pH} 7.0$, em tampão acetatofosfato-borato de sódio $(20 \mathrm{mM})$, com temperaturas entre $23{ }^{\circ} \mathrm{C}$ a $50{ }^{\circ} \mathrm{C}$ na presença e ausência de SDS e uréia. As concentrações variaram de 0 a $80 \mathrm{mM}$ e de 0 a $8 \mathrm{M}$, para SDS e uréia, respectivamente. 


\subsection{Resultados e Discussão: BSA na presença de uréia}

\section{Temperatura ambiente}

Na Figura 3.6 são mostradas as curvas de SAXS para BSA a temperatura ambiente, pH 7.0, variando a concentração de uréia. A representação de Kratky (em destaque na Figura) na forma de um sino indica que a BSA está na sua forma nativa. A adição de $3 \mathrm{M}$ de uréia altera parcialmente a conformação da proteína, que apresenta um completo desenovelamento na presença de $8 \mathrm{M}$ de uréia. Os resultados obtidos experimentalmente estão de acordo com os apresentados no Capítulo de livro "Small-Angle X-ray Scattering Applied to Proteins in Solution"[1].

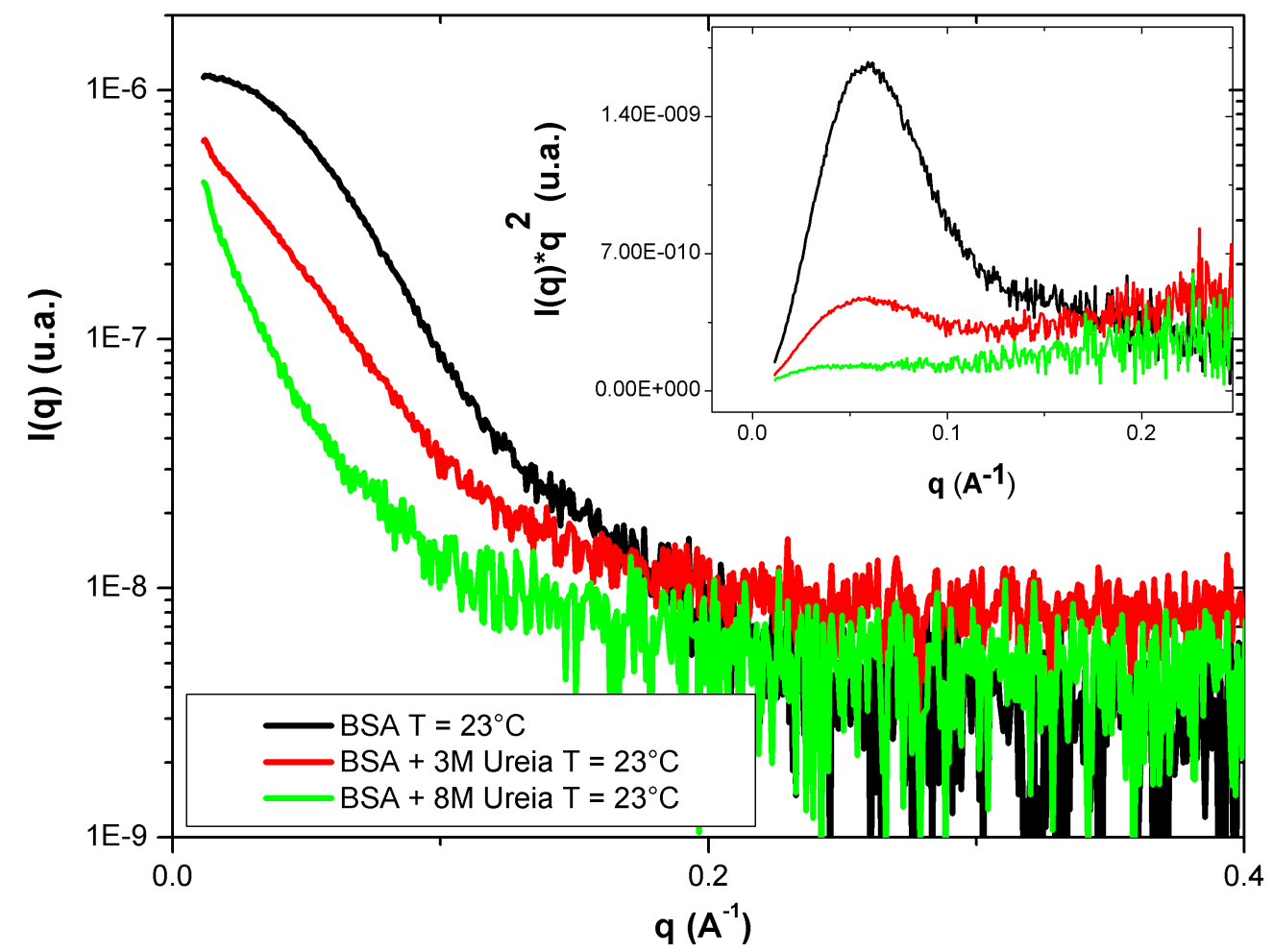

Figura 3.6: Curvas de SAXS para BSA a $\mathrm{T}=23^{\circ} \mathrm{C}, \mathrm{pH} 7.0$, na ausência e presença de $3 \mathrm{M}$ e $8 \mathrm{M}$ de uréia. O destaque na Figura mostra a representação de Kratky para as mesmas curvas, evidenciando o desenovelamento total da proteína a $8 \mathrm{M}$ de uréia. 


\section{Efeito térmico}

As curvas de SAXS para BSA, pH 7.0, não indicam uma variação significativa com a temperatura até $50^{\circ} \mathrm{C}$, como pode ser visto na Figura 3.7.A1. Por sua vez, a representação de Kratky para o mesmo conjunto de dados mostra que a proteína se mantém enovelada mesmo a $50^{\circ} \mathrm{C}$ (Figura. 3.7. A2).

As Figuras 3.7.B1 e C1 mostram as curvas para as amostras de BSA contendo $3 \mathrm{M}$ e $8 \mathrm{M}$ de uréia, respectivamente, também com variação de temperatura. Não há o aumento do grau de desenovelamento com relação a condição observada na temperatura ambiente, como pode ser visto nas representações de Kratky nas Figuras 3.7.B2 e 3.7.C2. Verifica-se, entretanto, que o aumento da temperatura induz um aumento na intensidade de espalhamento na região de $q \leq 0,015 \AA^{-1}$, indicando a formação de agregados, mesmo nas condições em que a proteína já está parcialmente desenovelada. Para uma melhor visualização do aumento de intensidade a baixos ângulos, a Figura 3.8 mostra os mesmos gráficos, porém em escala logarítmica. Os resultados indicam um aumento na agregação da BSA devido ao aumento de temperatura. De maneira interessante, observamos que na presença de $3 \mathrm{M}$ de uréia a temperatura de transição para a formação de agregados maiores é entre $40^{\circ} \mathrm{C}$ e $50^{\circ} \mathrm{C}$, enquanto que para $8 \mathrm{M}$ de uréia a temperatura de transição é entre $30^{\circ} \mathrm{C}$ e $40^{\circ} \mathrm{C}$. Portanto, a termoestabilidade diminui com o aumento de uréia em solução. 


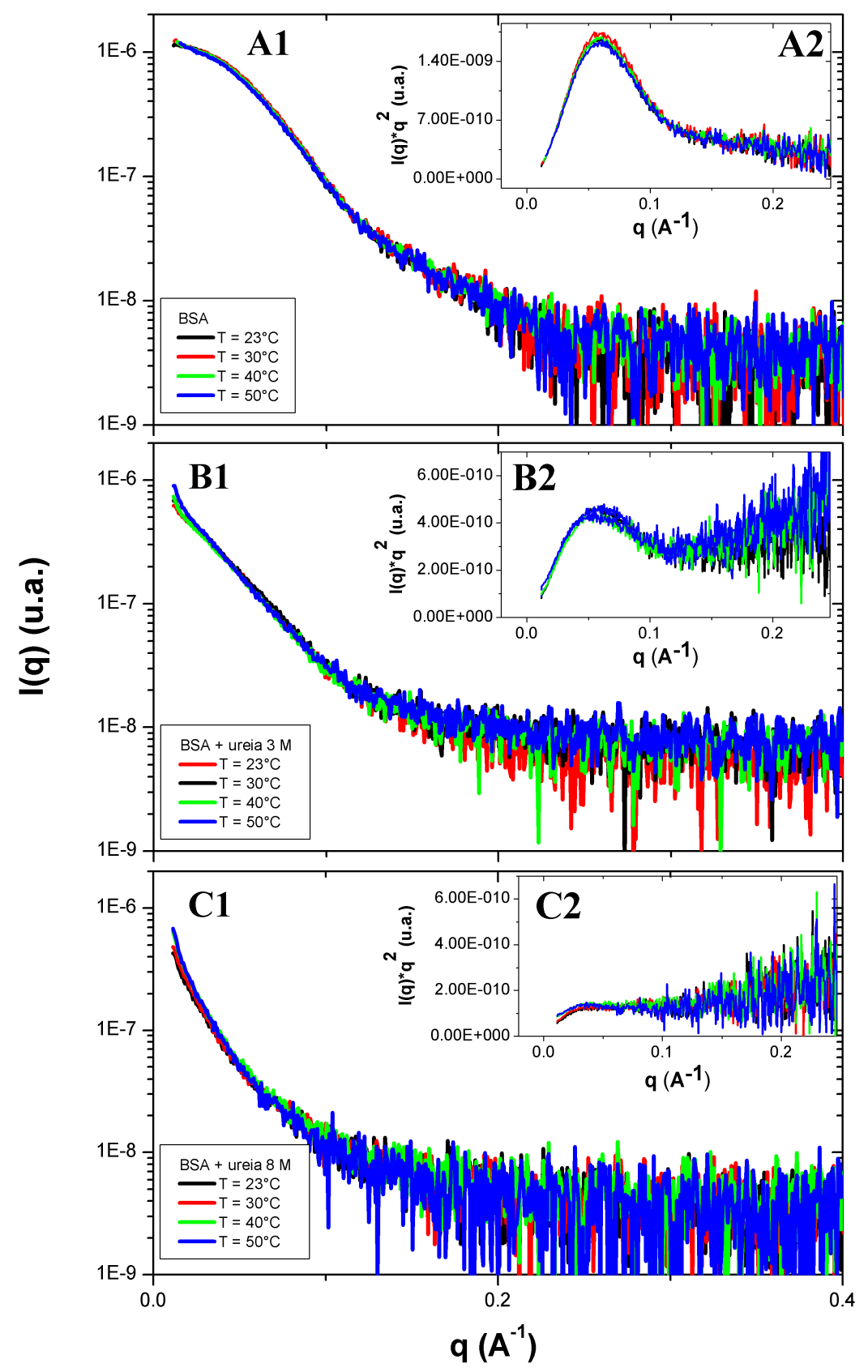

Figura 3.7: Curvas de SAXS para BSA, pH 7.0, a temperatura variável de $23^{\circ} \mathrm{C}$ a $50^{\circ} \mathrm{C}$, (A1) na ausência de uréia, na presença de (B1) $3 \mathrm{M}$ e (C1) $8 \mathrm{M}$ de uréia. Os destaques nas Figuras mostram as representações de Kratky para as mesmas curvas. 
Estabilidade térmica da albumina soro bovina (BSA) frente a dois agentes desnaturantes: SDS e uréia

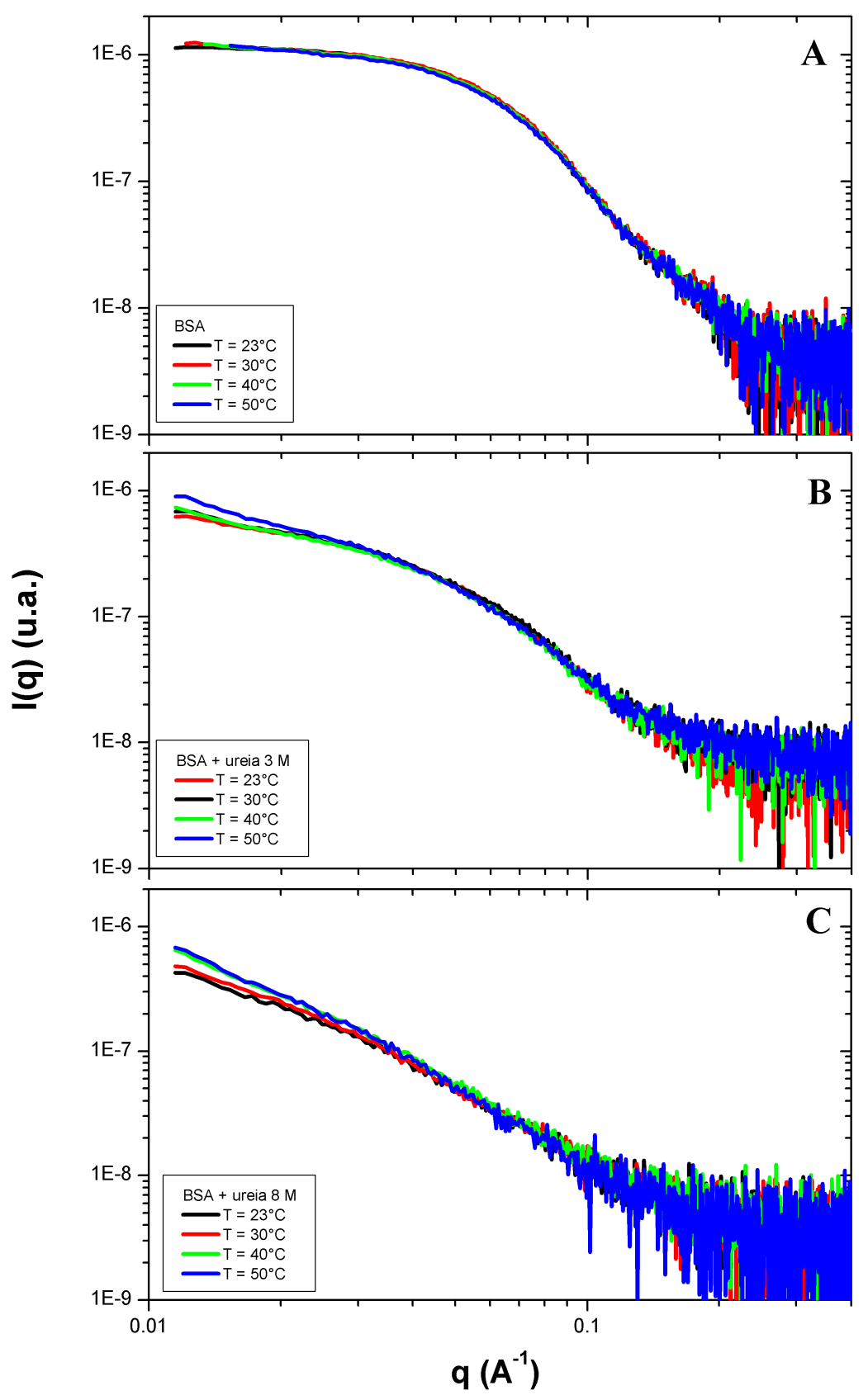

Figura 3.8: Curvas de SAXS (escala log x log) para BSA, pH 7.0, a temperatura variável de $23^{\circ} \mathrm{C}$ a $30^{\circ} \mathrm{C}$, (A) na ausência de uréia, na presença de (B) $3 \mathrm{M}$ e (C) $8 \mathrm{M}$ de uréia. 


\subsection{Resultados e Discussão: BSA na presença de SDS}

\section{Temperatura ambiente}

As curvas de SAXS para BSA a $\mathrm{T}=23^{\circ} \mathrm{C}$, pH 7.0, com SDS em concentração variável podem ser observadas na Figura 3.9. Para as amostras contendo 1 ou $3 \mathrm{mM}$ de SDS, razão molar BSA:SDS até 1:20, verifica-se que praticamente não há alterações nas curvas de SAXS, indicando que a conformação da proteína se mantém. Sabe-se que a BSA a pH 7.0 tem uma carga superficial de $-13 e$ 62. Quando dispersa em água, a curva de SAXS apresenta um pico de interferência de caráter repulsivo na região de $q$ pequenos. No nosso caso, a proteína está dispersa em tampão acetato-fosfato-borato de sódio $20 \mathrm{mM}$ e os resultados de SAXS na ausência e presença de até $3 \mathrm{mM}$ de SDS não indicam a presença de uma função de correlação entre proteínas. Já para BSA com 6 mM e 10 mM de SDS, razão molar BSA:SDS de 1:40 e 1:87, observamos um decréscimo de I(q) para q pequenos, tipico da influência de uma função de interferência $S(q)$ entre proteínas [62. Isto provavelmente deve ser induzido por algum aumento ou desbalanço de carga na superfície da proteína.

A grande alteração se dá nas curvas referentes às amostras com concentrações de $10 \mathrm{mM}$ a $30 \mathrm{mM}$ de SDS, razão molar BSA:SDS de 1:87 a 1:120, onde nota-se o aparecimento de pico micelar e alteração de conformação da proteína verificada pela alteração na representação de Kratky. Esses dados reproduzem os resultados apresentados por Gelamo e colaboradores 63. Entretanto, para a análise das curvas de SAXS, os autores utilizaram o modelo de micela para concentrações acima de $10 \mathrm{mM}$ de SDS e o modelo de "colar de pérolas"para avaliar a amostra com uma concentração igual a $50 \mathrm{mM}$ de SDS. Para análise no presente trabalho, como veremos mais adiante, além do uso do modelos citados, acrescentamos o modelo da estrutura cristalográfica da BSA (código pdb 4F5S), representando a proteína livre em solução. Com a contribuição desse modelo, obtemos ajustes ainda melhores do que os reportados anteriormente [63]. 
Estabilidade térmica da albumina soro bovina (BSA) frente a dois agentes desnaturantes: SDS e uréia
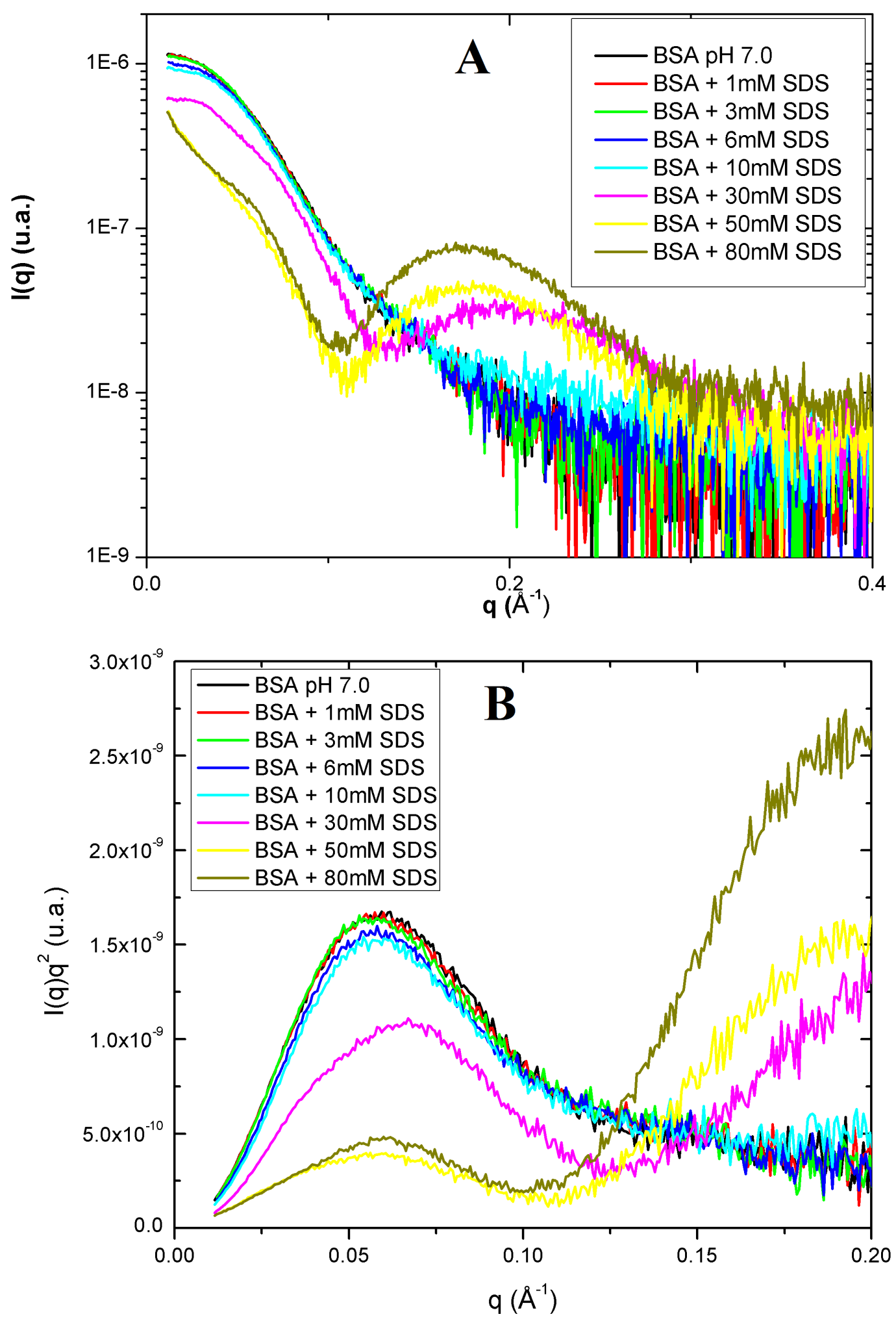

Figura 3.9: Curvas de SAXS para BSA a $\mathrm{T}=23^{\circ} \mathrm{C}$, pH 7.0, com SDS em concentração variável de 0 a $80 \mathrm{mM}$. O destaque na Figura mostra a representação de Kratky para as mesmas curvas. 
A Figura 3.10 mostra o melhor ajuste obtido para a curva de SAXS da amostra contendo BSA, em pH 7.0, a temperatura ambiente e na presença de $30 \mathrm{mM}$ de SDS. A linha preta representa o ajuste, enquanto que a linha azul e verde mostram a contribuição dos modelos da estrutura cristalográfica e micelas (elipsoide) livres em solução. Os parâmetros obtidos podem ser vistos na Tabela 3.1

As micelas de SDS formadas possuem raio hidrofóbico de aproximadamente $14 \AA$, com espessura da camada hidrofílica igual a 8,5 $\AA$ e anisotropia 1,5. Verificou-se que a concentração micelar crítica, cmc, é de 1,9 mM e a concentração de SDS é um pouco menor do que a nominalmente utilizada para a preparação da amostra (Tabela 3.1). Portanto, nesta condição, devem coexistir em solução proteínas da BSA com alguns monômeros de surfactantes ligados (lembrando que para pequenas concentrações de SDS não observamos alteração na estrutura conformacional da proteína) e micelas livres em solução. 
Estabilidade térmica da albumina soro bovina (BSA) frente a dois agentes

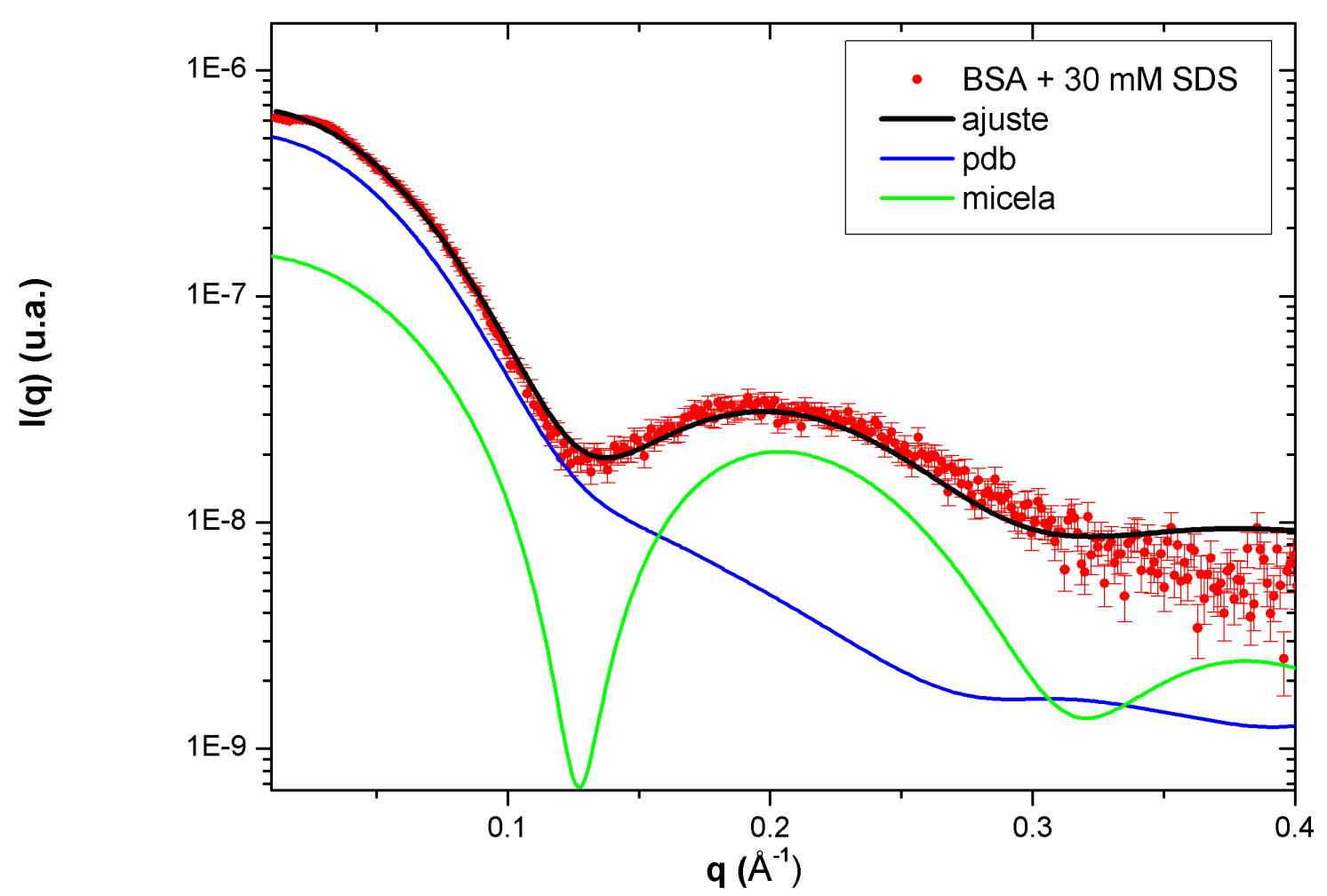

Figura 3.10: Melhor ajuste da curva de SAXS para BSA a $\mathrm{T}=23^{\circ} \mathrm{C}, \mathrm{pH} 7.0$, com $\mathrm{SDS}$ em concentração igual a $30 \mathrm{mM}$, utilizando os modelos da estrutura cristalográfica da proteína e micela (elipsoide). 
Tabela 3.1: Parâmetros dos ajustes experimentais para as amostras de BSA com 30 $\mathrm{mM}$ e $50 \mathrm{mM}$ de SDS.

\begin{tabular}{c|c|c}
\hline modelo & $\begin{array}{c}\text { Proteínas e micelas não } \\
\text { interagentes em solução }\end{array}$ & $\begin{array}{c}\text { "Colar de pérolas" e } \\
\text { proteína livre em solução }\end{array}$ \\
\hline concentração de SDS & $30 \mathrm{mM}$ & $50 \mathrm{mM}$ \\
\hline cmc $\left(\times 10^{-3} \mathrm{M}\right)$ & $1,9(1)$ & $1,1(1)$ \\
$\mathrm{c}_{\text {sds }}(\mathrm{mM})$ & $34,5(1)$ & $50,0(1)$ \\
$\nu$ & $1,5(1)$ & $1,6(1)$ \\
$\mathrm{R}_{\text {par }}(\AA)$ & $13,7(2)$ & $15,2(3)$ \\
$\mathrm{R}_{\text {shell }}(\AA)$ & $8,5(3)$ & $6,3(4)$ \\
$\rho_{\text {shell }} e^{-} / \AA^{3}$ & $0,40(1)$ & $0,39(1)$ \\
$\mathrm{N}$ & $45(4)$ & $67(6)$ \\
$\mathrm{d}_{\text {cor }}$ & $1,00(1)$ & $1,00(1)$ \\
$\%_{\mathrm{BSA} \text { livre }}$ & 100 & $14(3)$ \\
$\mathrm{d}$ & $\left({ }^{*}\right)$ & $1,01(1)$ \\
$\xi(\AA)$ & $\left(^{*}\right)$ & $279(32)$ \\
fundo $\left(\times 10^{-9}\right.$ u.a. $)$ & $5,7(2)$ & $3(1)$ \\
\hline
\end{tabular}

${ }^{(*)}$ Este parâmetro não se aplica a este modelo. 
Já na Figura 3.11, podemos verificar que mesmo o melhor ajuste obtido utilizando os modelos da estrutura cristalográfica da proteína e micela não fornece um bom ajuste dos dados experimentais de amostras de BSA na presença de $50 \mathrm{mM}$ de SDS em solução aquosa.

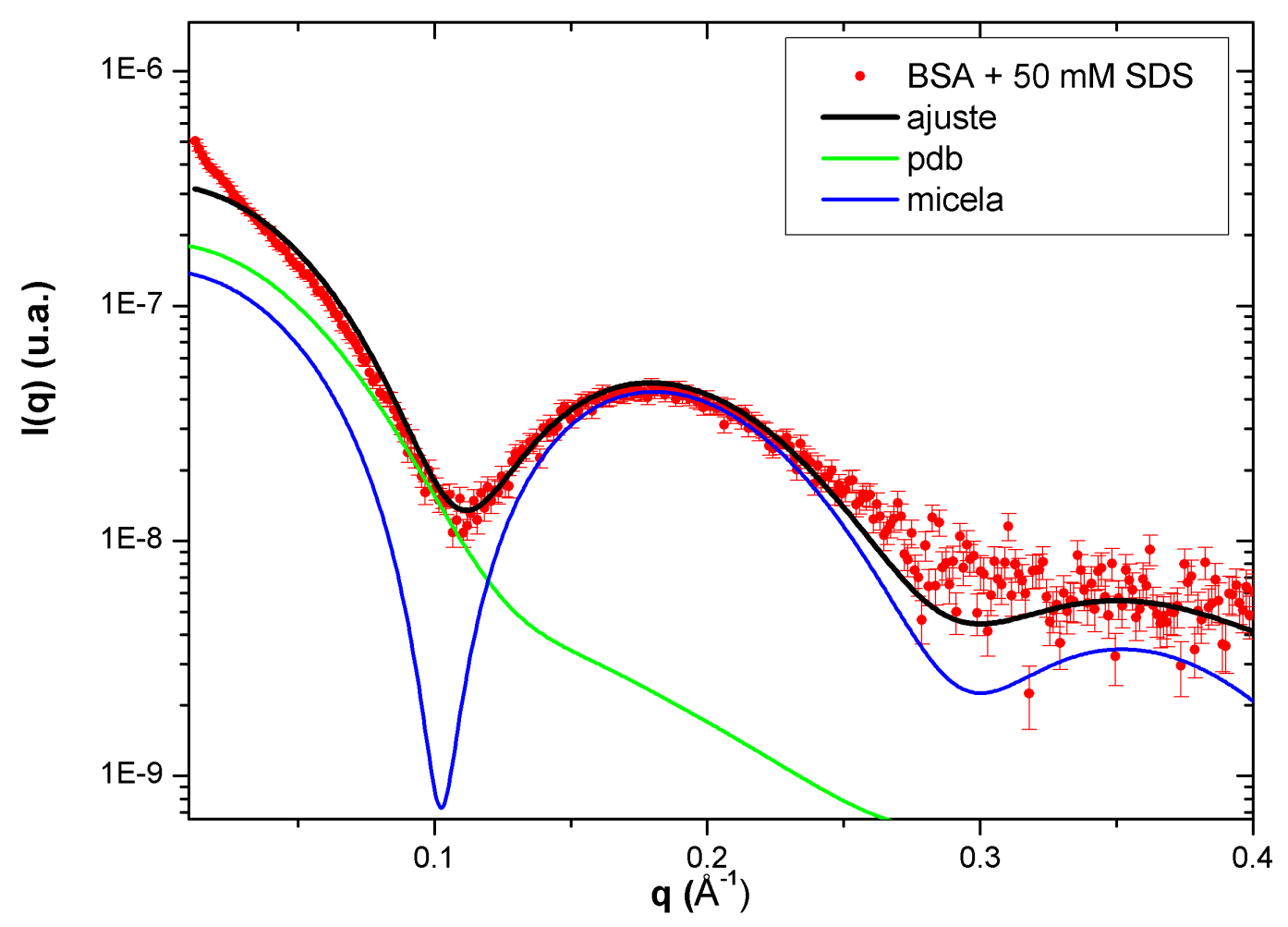

Figura 3.11: Melhor ajuste da curva de SAXS para BSA a $\mathrm{T}=23^{\circ} \mathrm{C}, \mathrm{pH} 7.0$, com $\mathrm{SDS}$ em concentração igual a $50 \mathrm{mM}$, utilizando os modelos da estrutura cristalográfica da proteína e micelas livres em solução.

Na Figura 3.12 é possível observar que curva referente a amostra com uma concentração igual a $50 \mathrm{mM}$ de SDS foi satisfatoriamente analisada com o modelo de "colar de pérolas". O ajuste com este modelo, havia se mostrado satisfatório também para a BSA, nesta concentração, em pH 5.4 [55]. Os parâmetros ajustados podem ser vistos na Tabela 3.1. Verifica-se que há $14 \%$ de BSA livre em solução sem alteração da densidade da camada de hidratação. As micelas formadas possuem raio de $15 \AA$, com espessura da camada hidrofílica de aproximadamente $6 \AA$, de densidade eletrônica similar ao observado para a amostra com $30 \mathrm{mM}$. 
O volume da micela é correspondente a 67 moléculas de SDS e a distância entre micelas adjacentes é de aproximadamente $280 \AA$, com dimensão fractal igual a 1,01, indicando que nestas condições a proteína deve estar desenovelada.

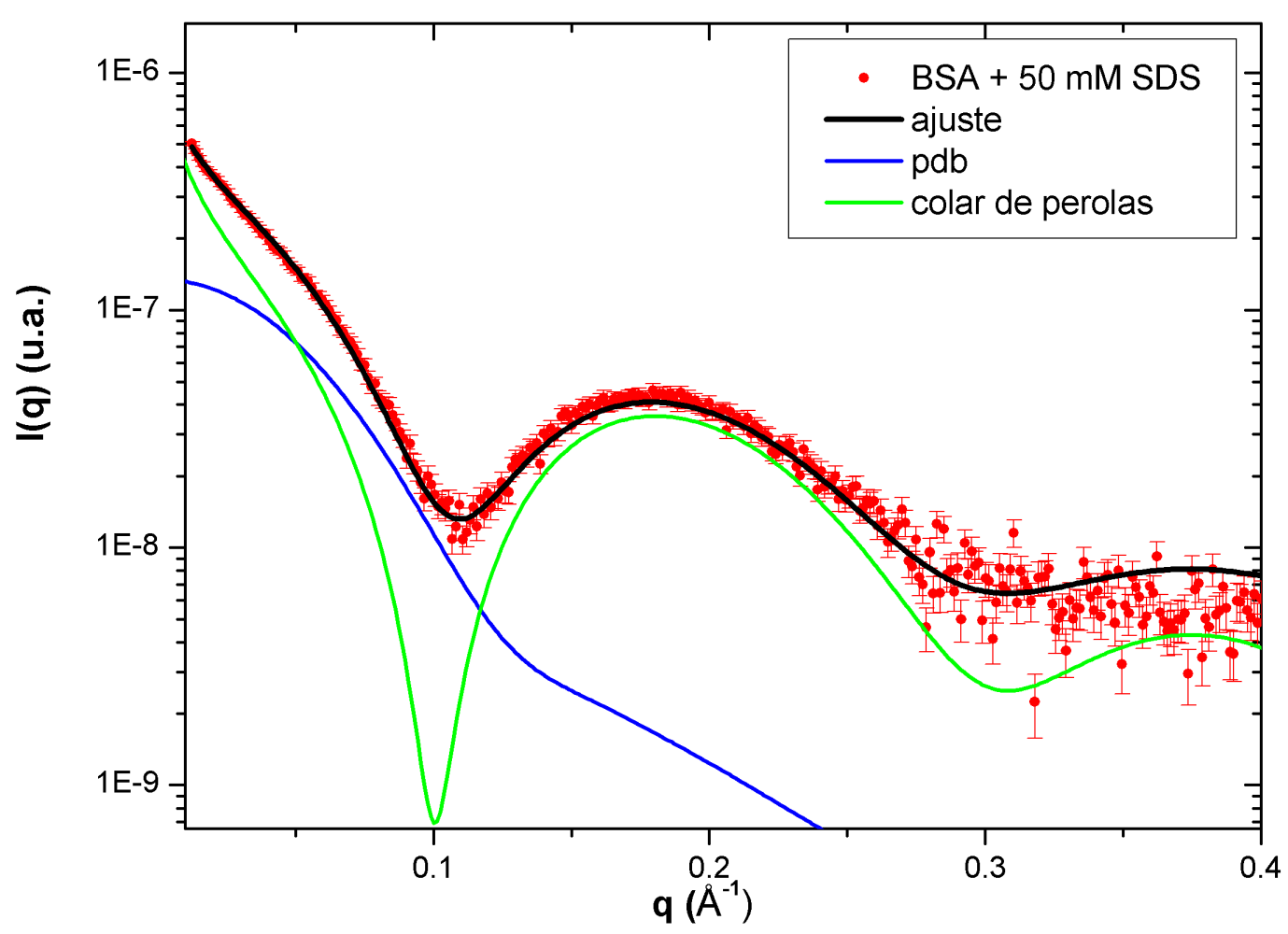

Figura 3.12: Melhor ajuste da curva de SAXS para BSA a $\mathrm{T}=23^{\circ} \mathrm{C}$, pH 7.0, com SDS em concentração igual a $50 \mathrm{mM}$, utilizando os modelos da estrutura cristalográfica da proteína e "colar de pérolas". 


\section{Efeito térmico}

Na Figura 3.13 estão representadas as curvas de SAXS para BSA, pH 7.0, a temperatura variável de $23^{\circ} \mathrm{C}$ a $50^{\circ} \mathrm{C}$, com SDS em concentração de $1 \mathrm{mM}$ a $10 \mathrm{mM}$. Assim como observado para as amostras contendo uréia, pode-se concluir pelas representações de Kratky na Figura 3.13 que a temperatura não interfere na conformação da proteína, apenas favorece a formação de agregados a partir de $30^{\circ} \mathrm{C}$. Esse efeito da agregação dependente da temperatura é acentuado conforme aumenta-se a concentração de SDS, conforme pode ser visto na ampliação da região de $q$ pequenos na Figura 3.14 


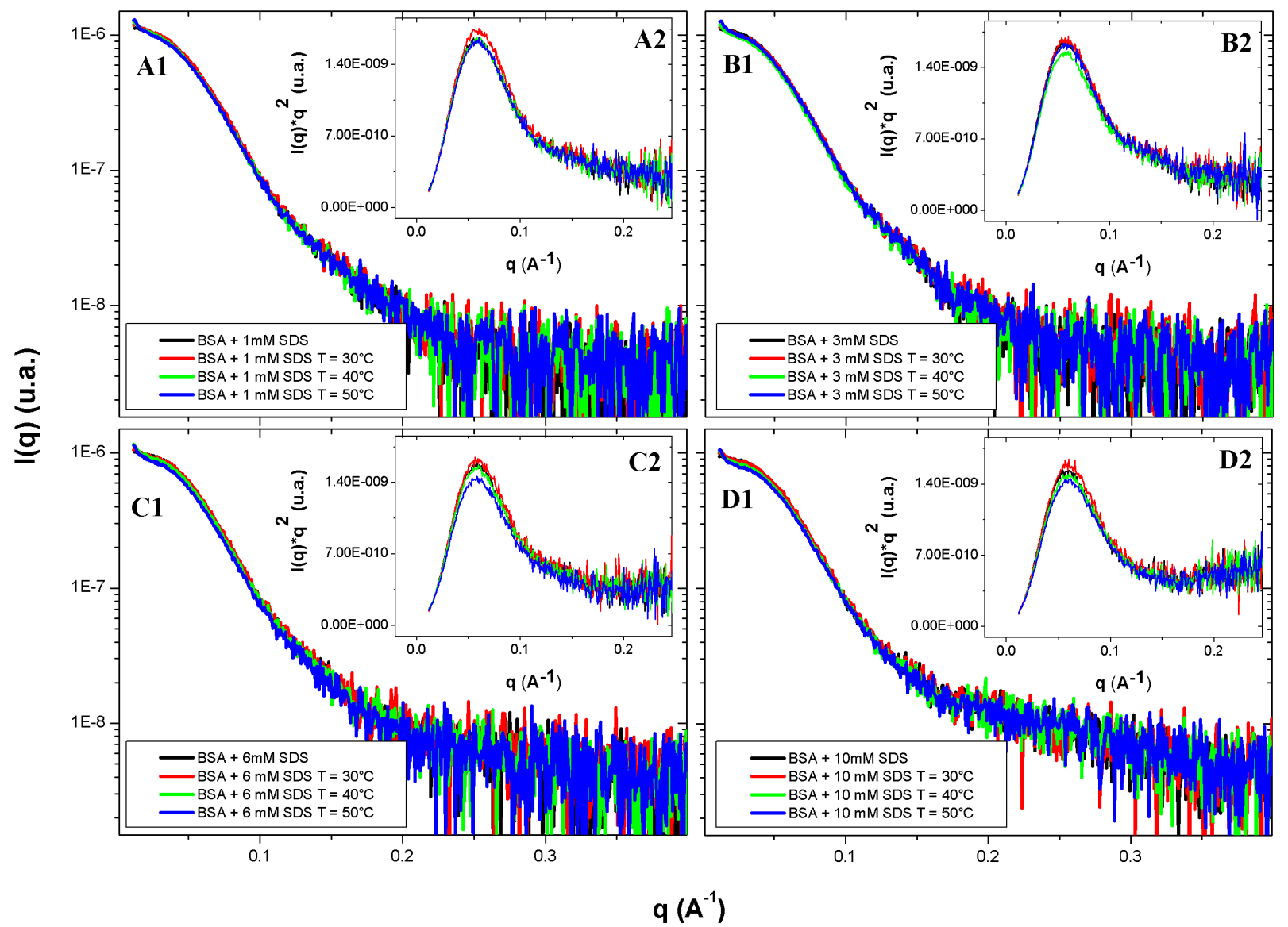

Figura 3.13: Curvas de SAXS para BSA, pH 7.0, a temperatura variável de $23^{\circ} \mathrm{C}$ a $50^{\circ} \mathrm{C}$, com SDS em concentração igual a (A) $1 \mathrm{mM}$, (B) $3 \mathrm{mM}$, (C) $6 \mathrm{~m} \mathrm{M} \mathrm{e} \mathrm{(D)} 10 \mathrm{mM}$. Os destaques nas Figuras mostram as representações de Kratky para as mesmas curvas. 
Estabilidade térmica da albumina soro bovina (BSA) frente a dois agentes desnaturantes: SDS e uréia

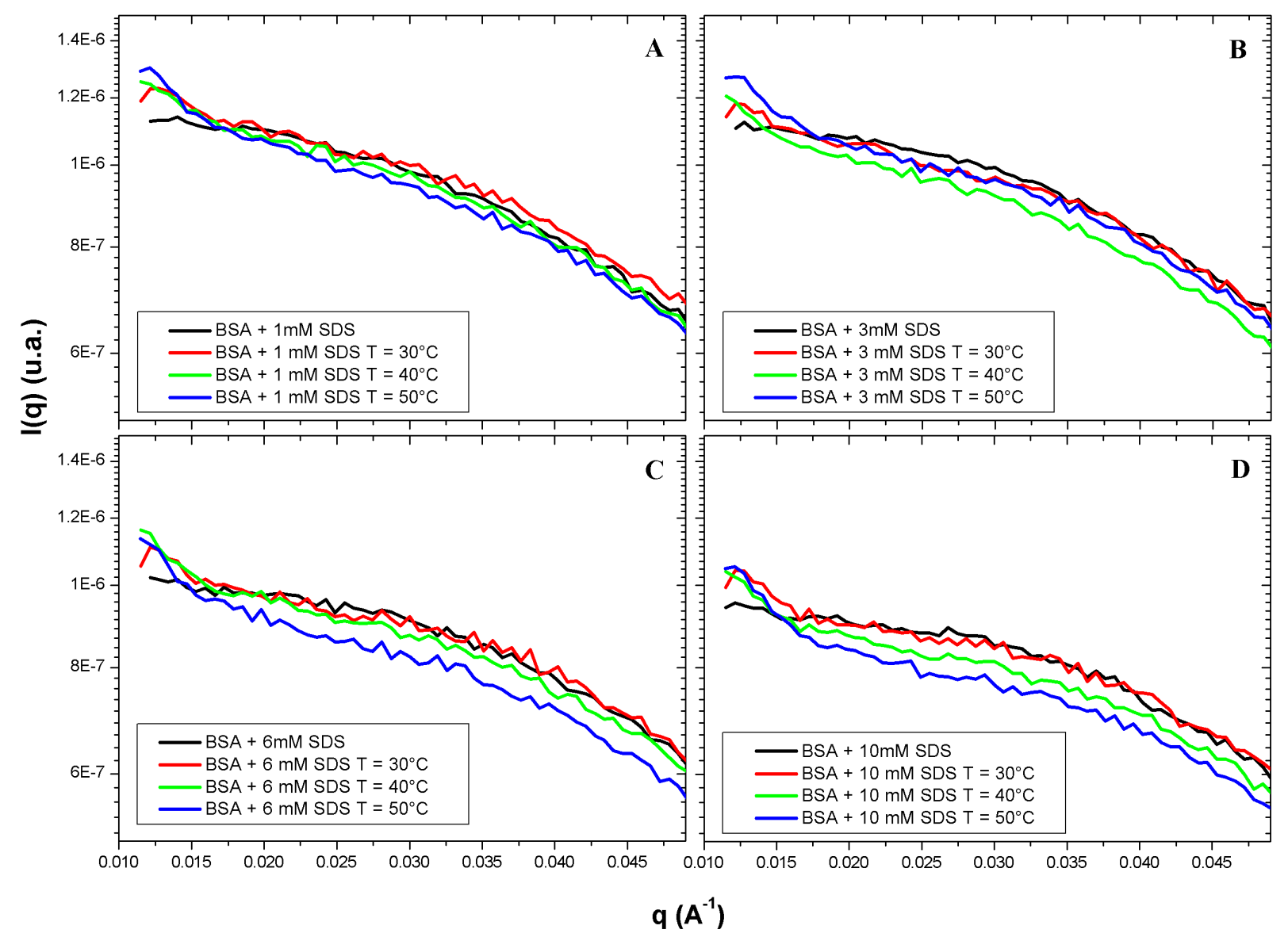

Figura 3.14: Ampliação da região de $q$ pequenos das curvas de SAXS para BSA, pH 7.0, a temperatura variável de $23^{\circ} \mathrm{C}$ a $50^{\circ} \mathrm{C}$, com SDS em concentração igual a (A) $1 \mathrm{mM}$, (B) 3 mM, (C) $6 \mathrm{~m} \mathrm{M} \mathrm{e} \mathrm{(D)} 10 \mathrm{mM}$. 
As curvas de SAXS para a BSA com 30 mM de SDS e suas representações de Kratky podem ser vistas na Figura 3.15.A. Da mesma maneira que relatado para as outras concentrações, o efeito da temperatura é observado apenas no aumento da agregação. Enquanto a temperatura de transição para concentrações até $10 \mathrm{mM}$ de SDS era entre $23^{\circ} \mathrm{C}$ e $30{ }^{\circ} \mathrm{C}$, para $30 \mathrm{mM}$ de SDS a temperatura de transição é entre $30^{\circ} \mathrm{C}$ e $40^{\circ} \mathrm{C}$. Na Figura 3.15.B as mesmas curvas estão representadas em escala logarítmica com enfoque na região que apresenta deslocamento no mínimo da micela para valores de q maiores com o aumento da temperatura. Tal deslocamento denota uma diminuição no tamanho da micela. 
Estabilidade térmica da albumina soro bovina (BSA) frente a dois agentes desnaturantes: SDS e uréia
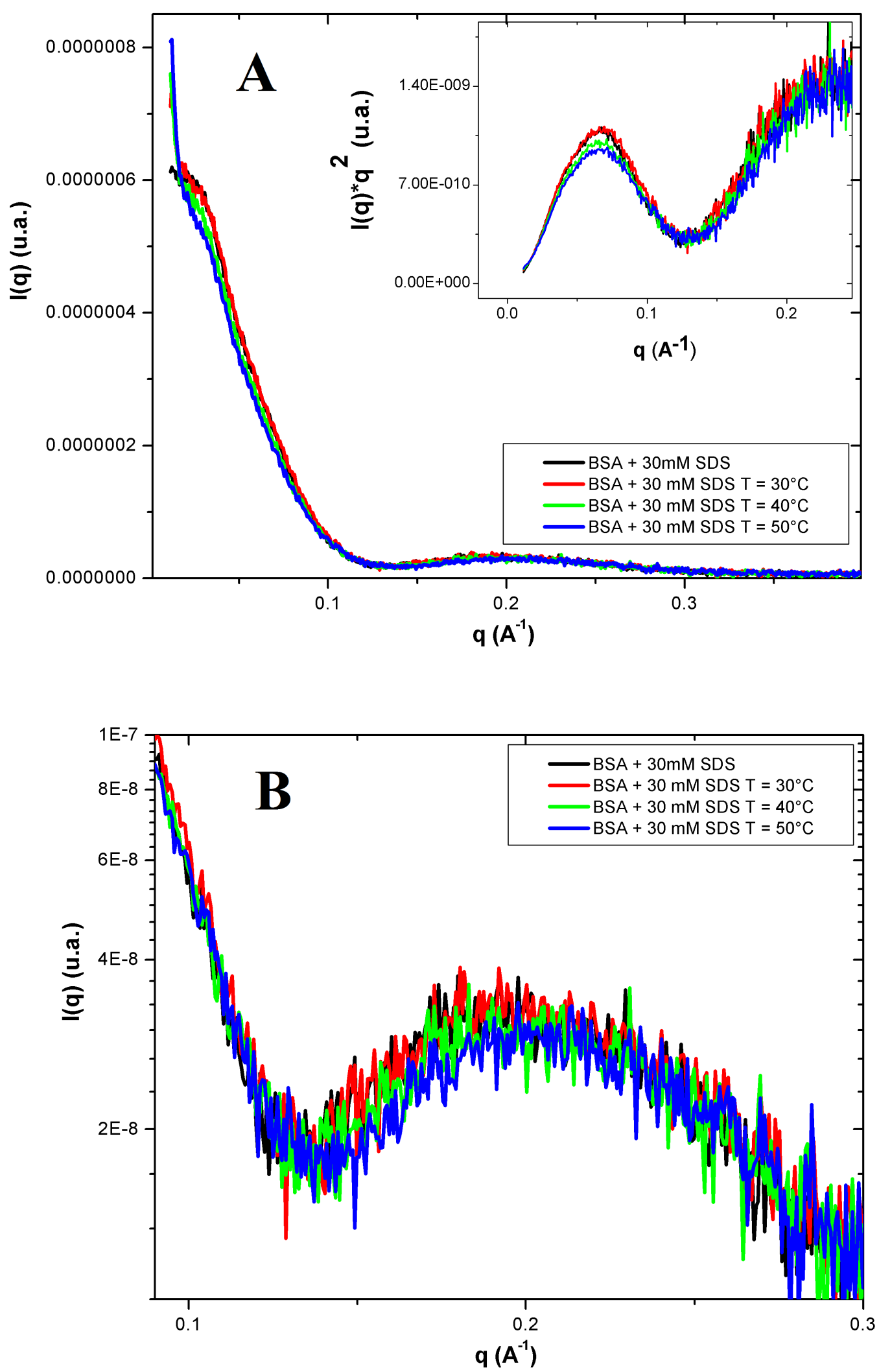

Figura 3.15: Curvas de SAXS para BSA, pH 7.0, a temperatura variável de $23^{\circ} \mathrm{C}$ a $50^{\circ} \mathrm{C}$, com SDS a $30 \mathrm{mM}$. (A) Gráfico em escala linear, com destaque mostrando as representações de Kratky para as mesmas curvas. (B) Ampliação do gráfico em escala logarítmica para ressaltar o deslocamento do mínimo da micela. 


\subsection{Resultados e Discussão: BSA na presença de uréia e SDS}

\section{Temperatura ambiente}

Os resultados obtidos para as amostras de BSA, a temperatura ambiente, pH 7.0, na presença de 3M de uréia e concentração variável de SDS, bem como as respectivas representações de Kratky podem ser visualizados na Figura 3.16 .

Conforme descrito na Seção 3.7, a BSA na presença de $3 \mathrm{M}$ de uréia já encontra-se parcialmente desenovelada. Analisando a representação de Kratky, observa-se uma alteração na conformação dependente da concentração de SDS.

A partir de $6 \mathrm{mM}$ de SDS verifica-se um mínimo referente a micela em solução que é deslocado para valores de q menores com o aumento da concentração de SDS. Esse deslocamento indica um aumento do diâmetro da micela.

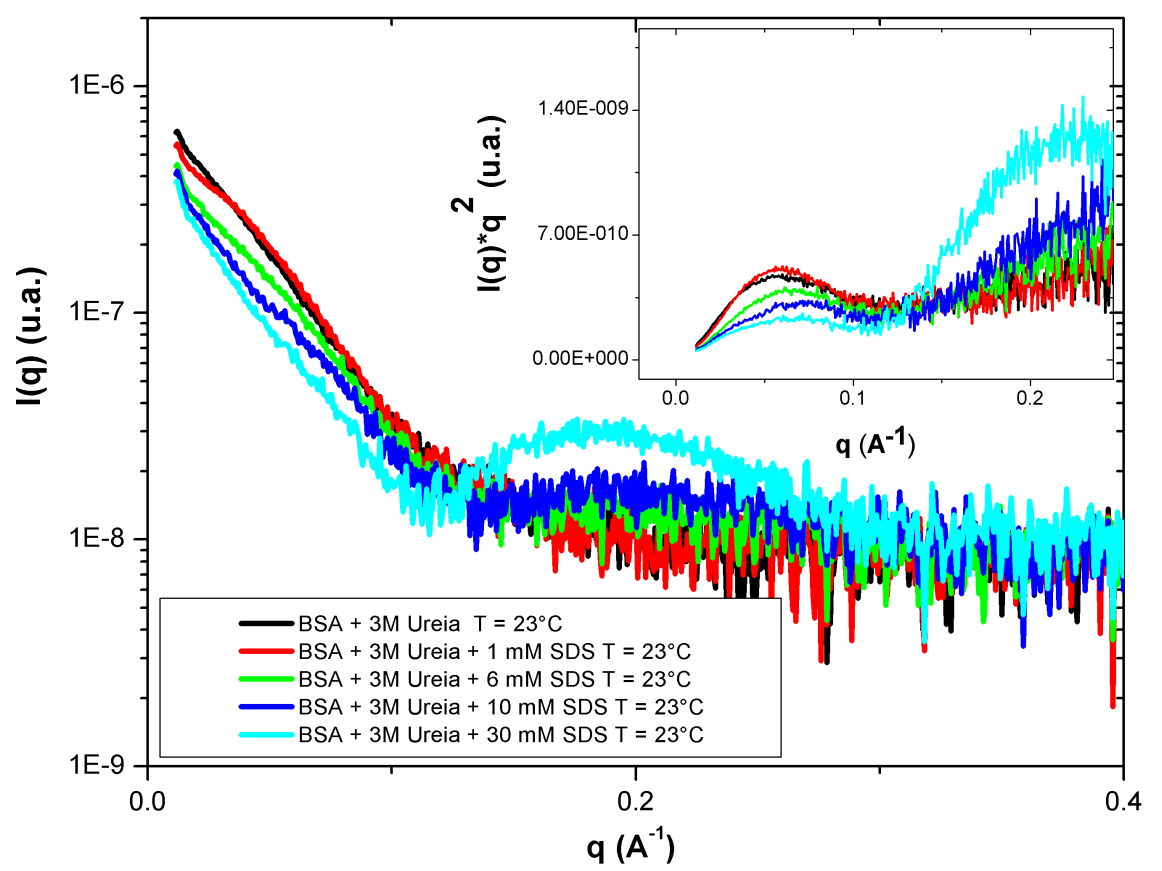

Figura 3.16: Curvas de SAXS para BSA a $\mathrm{T}=23^{\circ} \mathrm{C}$, $\mathrm{pH} 7.0$, na presença de $3 \mathrm{M}$ de uréia e concentração variável de 0 a $30 \mathrm{mM}$ de SDS. O destaque na Figura mostra a representação de Kratky para as mesmas curvas. 
Para visualizar melhor os resultados, na Figura 3.17 são mostradas as curvas de BSA na ausência e presença de $3 \mathrm{M}$ de uréia para as diferentes concentrações de SDS. Para as concentrações até $6 \mathrm{mM}$ de SDS, é possível verificar que o efeito da uréia em alterar a conformação da proteína é predominante em relação ao efeito de SDS. A partir de 10 mM, a presença de SDS também contribui para o desenovelamento da proteína.
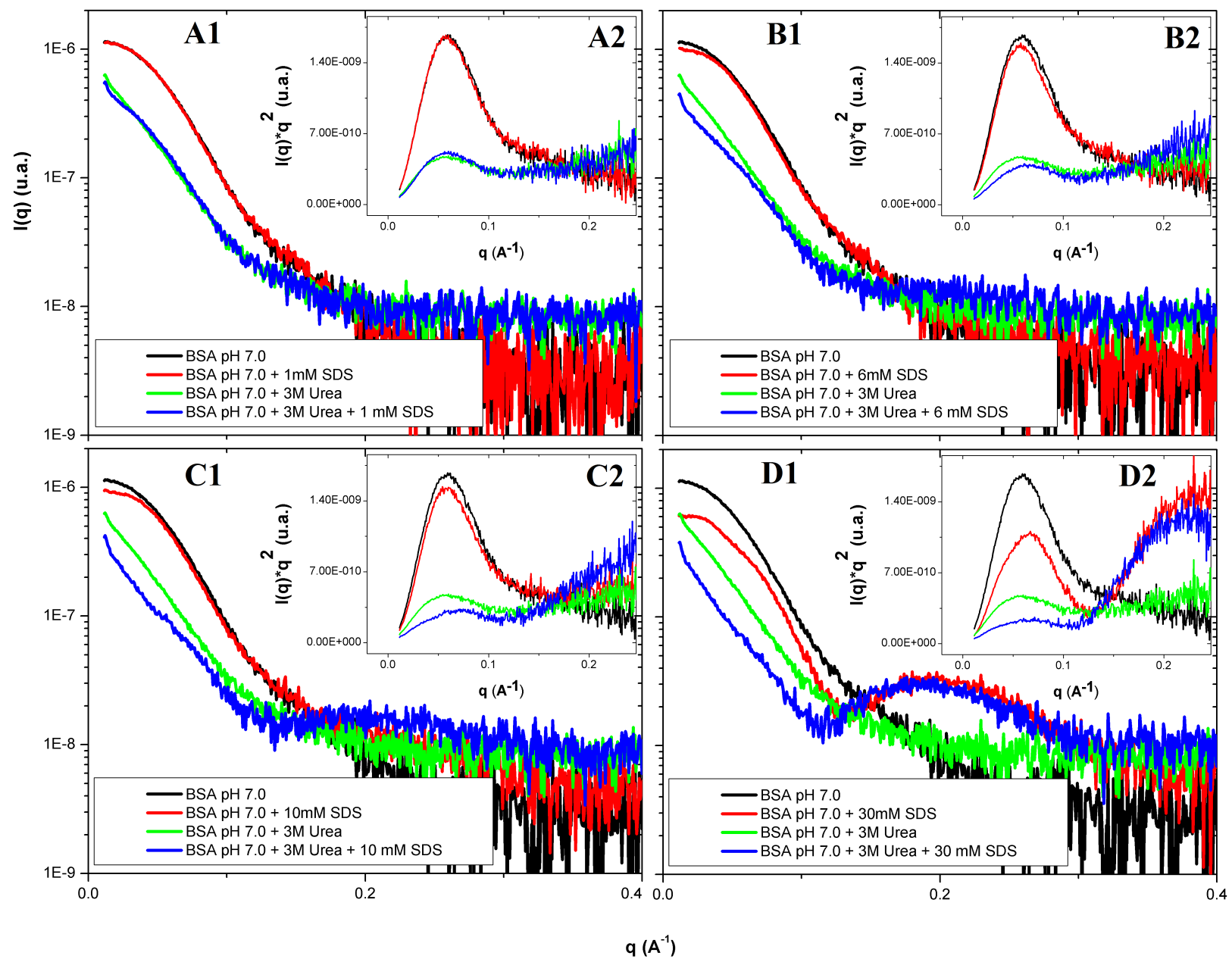

Figura 3.17: Curvas de SAXS para BSA a $\mathrm{T}=23^{\circ} \mathrm{C}, \mathrm{pH} 7.0$, na ausência e presença de 3 M uréia e SDS em concentração igual a (A) $1 \mathrm{mM}$, (B) $6 \mathrm{mM}$, (C) $10 \mathrm{mM}$ e (D) 30 mM. Os destaques nas Figuras mostram a representação de Kratky para as mesmas curvas. 
A Figura 3.18 mostra os melhores ajustes, representados pelas linhas contínuas, obtidos para as curvas de SAXS das amostras contendo BSA, em pH 7.0, a temperatura ambiente, $3 \mathrm{M}$ de uréia e concentração variável de SDS. Os parâmetros resultantes dos ajustes podem ser vistos na Tabela 3.2 .

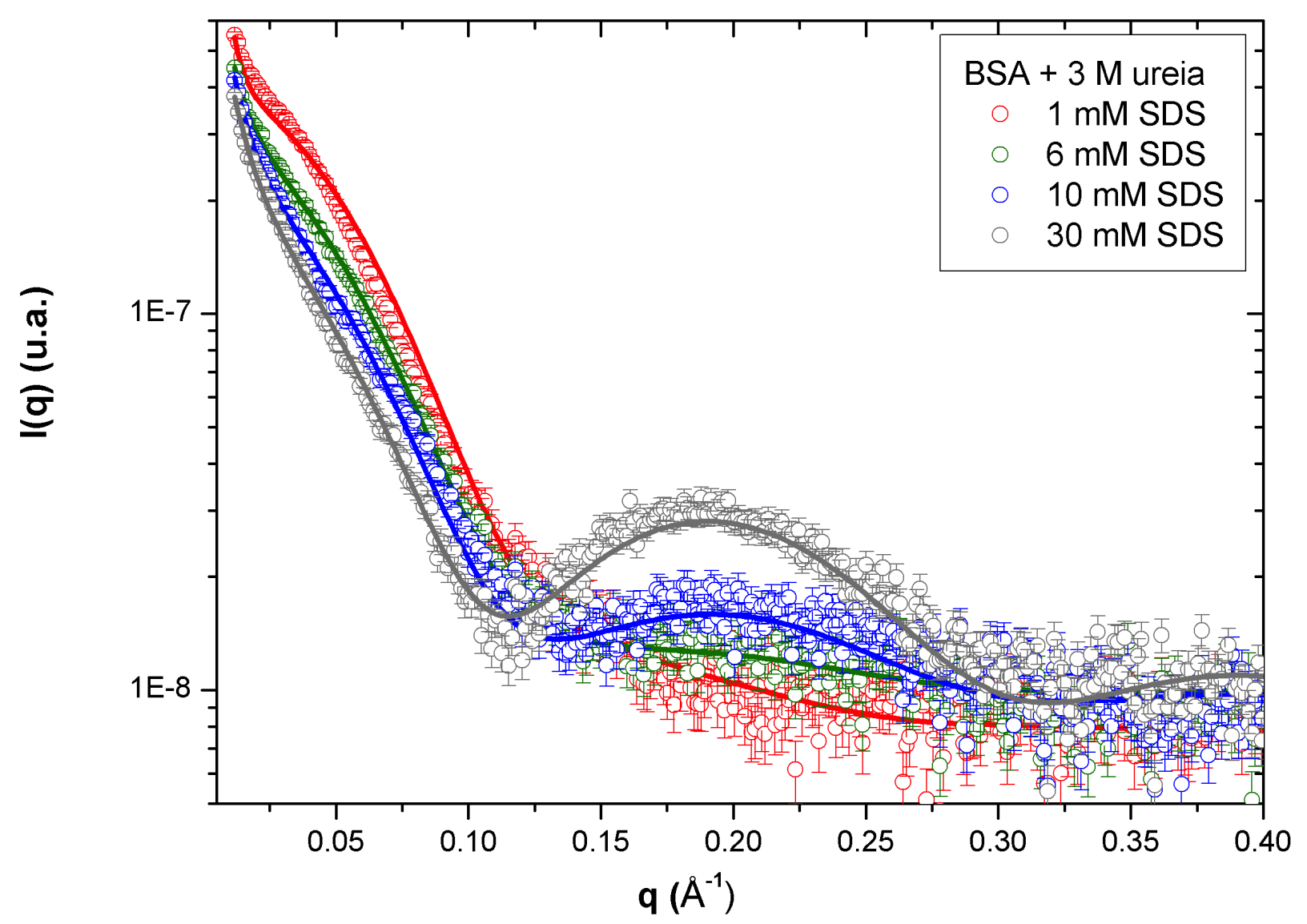

Figura 3.18: Melhores ajustes das curvas de $\mathrm{SAXS}$ para $\mathrm{BSA}$ a $\mathrm{T}=23^{\circ} \mathrm{C}, \mathrm{pH} 7.0$, com $3 \mathrm{M}$ de uréia e concentração variável de SDS, utilizando os modelos da estrutura cristalográfica da proteína e "colar de pérolas".

A porcentagem de proteína livre em solução diminui com o aumento da concentração de SDS. A densidade relativa da camada de hidratação, $\mathrm{d}_{c o r}$, não apresenta variações significativas. Com relação às micelas aderidas à cadeia proteica parcialmente desenovelada, verifica-se que o raio da região interna se mantém constante, porém há um aumento da anisotropia com a concentração de SDS, acarretando no aumento do número de moléculas 
Tabela 3.2: Parâmetros dos ajustes experimentais para as amostras de BSA, SDS e 3 M de Uréia.

\begin{tabular}{c|cccc}
\hline concentração de SDS & $1 \mathrm{mM}$ & $6 \mathrm{mM}$ & $10 \mathrm{mM}$ & $30 \mathrm{mM}$ \\
\hline \%BSA livre & $46(3)$ & $45(5)$ & $12(3)$ & $9(3)$ \\
cmc $\left(\times 10^{-4} \mathrm{M}\right)$ & $1,1(6)$ & $3(1)$ & $16(6)$ & $11(5)$ \\
$\nu$ & $1,1(4)$ & $1,1(3)$ & $1,2(3)$ & $1,3(1)$ \\
$\mathrm{R}_{\text {par }}(\AA)$ & $13(1)$ & $13,8(6)$ & $13,6(5)$ & $14(1)$ \\
$\mathrm{N}$ & $28(3)$ & $35(3)$ & $36(3)$ & $43(4)$ \\
$\mathrm{d}_{\text {cor }}$ & $1,02(4)$ & $1,07(3)$ & $1,04(3)$ & $1,00(3)$ \\
$\mathrm{R}_{\text {shell }}(\AA)$ & $10(2)$ & $8(1)$ & $9(2)$ & $7(1)$ \\
$\rho_{\text {shell }}\left(e^{-} / \AA^{3}\right)$ & $0,36(2)$ & $0,36(1)$ & $0,36(1)$ & $0,36(1)$ \\
$\mathrm{d}$ & $2,9(2)$ & $2,4(1)$ & $2,1(2)$ & $1,9(3)$ \\
$\xi(\AA)$ & $158(16)$ & $153(25)$ & $120(24)$ & $129(30)$ \\
fundo $\left(\times 10^{-9}\right.$ u.a. $)$ & $6,9(2)$ & $9,3(2)$ & $8,8(2)$ & $8,4(1)$ \\
\hline
\end{tabular}

por micela. Por sua vez, o raio da parte hidrofílica, $\mathrm{R}_{\text {shell }}$, diminuiu mantendo a densidade eletrônica inalterada. A dimensão fractal do modelo de colar de pérolas é de 2,9 para a amostra com $1 \mathrm{mM}$ de SDS, indicando uma conformação bem compacta. Conforme aumenta-se a concentração de SDS, a dimensão fractal diminui, refletindo o desenovelamento parcial da proteína. A distância entre micelas adjacentes decrescem sutilmente, considerando-se as incertezas associadas a estes parâmetros. Note que, a partir de $6 \mathrm{mM}$ de SDS, a estrutura parcialmente desenovelada por $3 \mathrm{M}$ de uréia sofre alteração conformacional ainda mais acentuada. Os valores de dimensão fractal obtidos para $1 \mathrm{mM}$ de SDS na presença de uréia não refletem este desenovelamento e serão posteriormente revistos utilizando-se possivelmente o modelo de Debye associado a micelas livres em solução.

Comparando estes resultados com os parâmetros obtidos para a BSA com $50 \mathrm{mM}$ de SDS, sem uréia (Tabela 3.1), é possível denotar que a presença de uréia diminui o tamanho das micelas e a densidade eletrônica da camada hidrofóbica. Outra contribuição é observada no espaçamento entre micelas, diminuido pela presença de uréia. 
Na Figura 3.19 são apresentados os melhores ajustes, representados pelas linhas contínuas, para as curvas de SAXS das amostras contendo BSA, em pH 7.0, a temperatura ambiente, $8 \mathrm{M}$ de uréia e concentração variável de SDS. Os parâmetros obtidos a partir dos ajustes das curvas de SAXS referente ao sistema contendo $8 \mathrm{M}$ de uréia são apresentados na Tabela 3.3 .

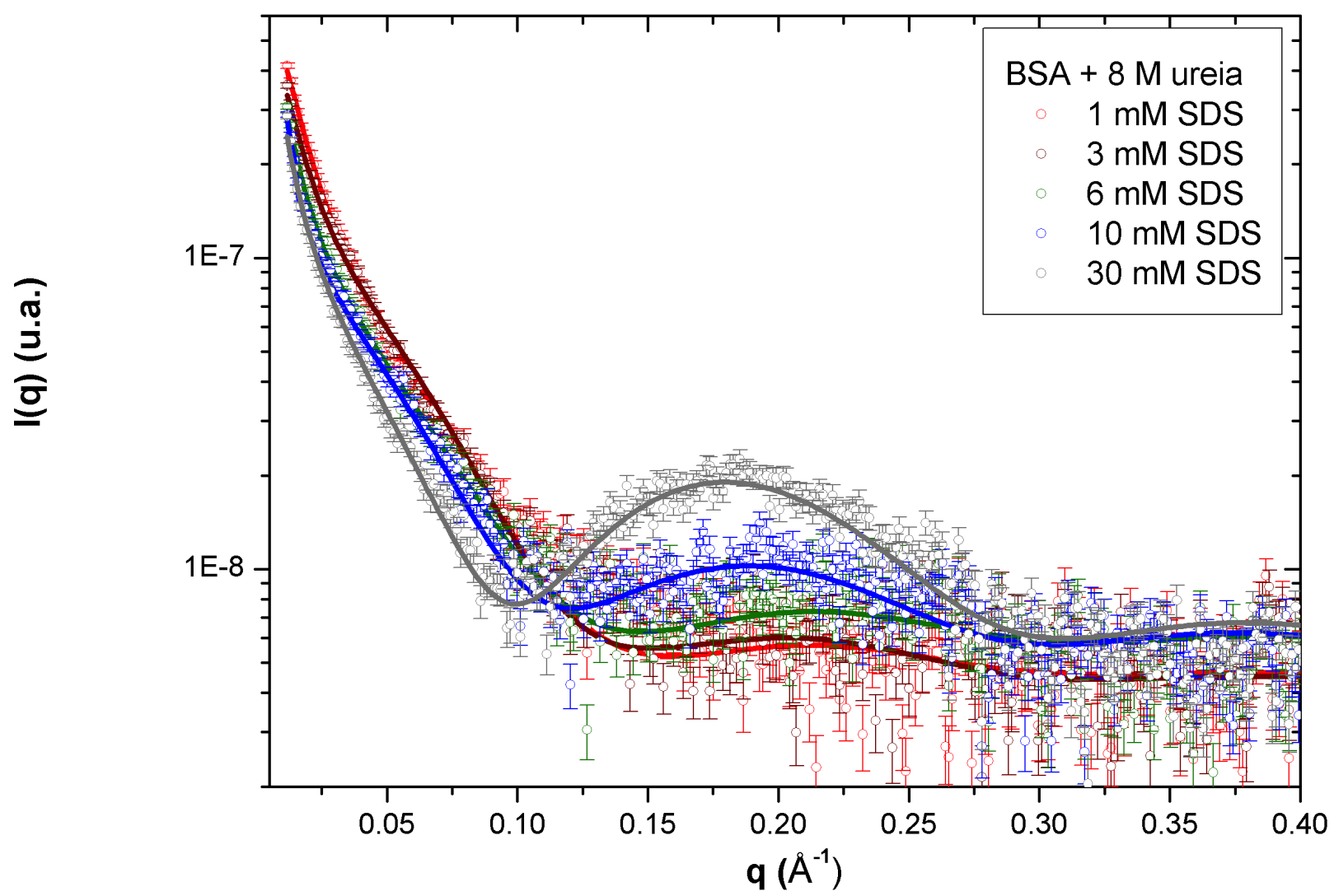

Figura 3.19: Melhores ajustes das curvas de SAXS para BSA a $\mathrm{T}=23^{\circ} \mathrm{C}, \mathrm{pH} 7.0$, com $3 \mathrm{M}$ de uréia e concentração variável de SDS, utilizando os modelos da estrutura cristalográfica da proteína e "colar de pérolas".

Com o aumento da concentração de $3 \mathrm{M}$ para $8 \mathrm{M}$ de uréia, é possível observar que, para as mesmas concentrações de SDS, a porcentagem de proteína livre em solução diminui. A concentração micelar crítica, cmc, também diminui quando comparado aos resultados obtidos para $3 \mathrm{M}$ de uréia. Para BSA com $3 \mathrm{M}$ de uréia e concentração variável de SDS, a densidade eletrônica da região hidrofílica se mantém constante a $0,36 e^{-} / \AA^{3}$. Para as 
Tabela 3.3: Parâmetros dos ajustes experimentais para as amostras de BSA, SDS e 8M de Uréia.

\begin{tabular}{c|ccccc}
\hline SDS & $1 \mathrm{mM}$ & $3 \mathrm{mM}$ & $6 \mathrm{mM}$ & $10 \mathrm{mM}$ & $30 \mathrm{mM}$ \\
\hline$\%$ BSA livre & $20(3)$ & $20(4)$ & $12(4)$ & $6(3)$ & $3(1)$ \\
$\mathrm{cmc}\left(\times 10^{-4} \mathrm{M}\right)$ & $20(5)$ & $1,0(6)$ & $30(1)$ & $1,7(6)$ & $1,0(6)$ \\
$\nu$ & $1,1(1)$ & $1,0(3)$ & $1,1(3)$ & $1,1(1)$ & $1,5(2)$ \\
$\mathrm{R}_{\text {par }}(\AA)$ & $13,3(3)$ & $14(1)$ & $15(1)$ & $15(1)$ & $15(1)$ \\
$\mathrm{N}$ & $30(3)$ & $33(3)$ & $44(4)$ & $46(5)$ & $61(6)$ \\
$\mathrm{d}_{\text {cor }}$ & $1,00(1)$ & $1,00(2)$ & $1,04(2)$ & $1,09(3)$ & $1,00(3)$ \\
$\mathrm{R}_{\text {shell }}(\AA)$ & $10,3(5)$ & $10(1)$ & $7(1)$ & $8(1)$ & $6(1)$ \\
$\rho_{\text {shell }}\left(e^{-} / \AA^{3}\right)$ & $0,44(1)$ & $0,39(3)$ & $0,44(2)$ & $0,37(2)$ & $0,38(2)$ \\
$\mathrm{d}$ & $2,6(1)$ & $2,5(2)$ & $1,9(2)$ & $2,1(1)$ & $1,7(3)$ \\
$\xi(\AA)$ & $58(4)$ & $64(12)$ & $128(33)$ & $245(37)$ & $265(18)$ \\
fundo $\left(\times 10^{-9}\right.$ u.a. $)$ & $4,4(4)$ & $4,2(1)$ & $5,8(2)$ & $5,5(3)$ & $5,0(6)$ \\
\hline
\end{tabular}

amostras com $8 \mathrm{M}$ de uréia a densidade eletrônica desta região varia de $0,4 e^{-} / \AA^{3}$, para $1 \mathrm{mM}$ de SDS, até $0,38 e^{-} / \AA^{3}$ (com $30 \mathrm{mM}$ de SDS), valor ainda superior ao observado anteriormente.

A dimensão fractal segue o mesmo comportamento que o descrito para $3 \mathrm{M}$ : há uma diminuição com o aumento da concentração de SDS, indicando uma configuração mais aberta. Enquanto que a distância entre micelas diminui com o aumento da concentração de SDS na presença de $3 \mathrm{M}$ de uréia, para $8 \mathrm{M}$ é observado o efeito oposto: a distância passa a aumentar para concentrações de SDS superiores a $6 \mathrm{mM}$, se mantendo estável a partir de $10 \mathrm{mM}$ até $30 \mathrm{mM}$ de SDS. Novamente, como para o $3 \mathrm{M}$ de uréia, os valores de dimensão fractal obtidos para $1 \mathrm{mM}$ e $3 \mathrm{mM}$ de SDS na presença de $8 \mathrm{M}$ uréia não condizem com o desenovelamento observado na representação de Kratky e também deverão ser revistos utilizando-se outros modelos para descrever esta condição, possivelmente fazendo uso do modelo de Debye associado a micelas livres em solução. 


\section{Efeito térmico}

Conforme os resultados da Figura 3.20 o efeito da temperatura nas amostras de BSA na presença de uréia e SDS é o mesmo que para os sistemas isolados de BSA e Uréia e BSA e SDS: observa-se um aumento da agregação dependente da temperatura, mas sem alteração na conformação da proteína pré-estabelecida pelos agentes desnaturantes. A temperatura de transição é ente $40^{\circ} \mathrm{C}$ e $50^{\circ} \mathrm{C}$ para condição onde há $1 \mathrm{mM}$ de SDS e entre $30^{\circ} \mathrm{C}$ e $40^{\circ} \mathrm{C}$, para concentrações superiores a $6 \mathrm{mM}$ de SDS. A 8 M de uréia, a proteína já se apresenta tão desenovelada que não realizamos medidas com variação de temperatura. 
Estabilidade térmica da albumina soro bovina (BSA) frente a dois agentes desnaturantes: SDS e uréia

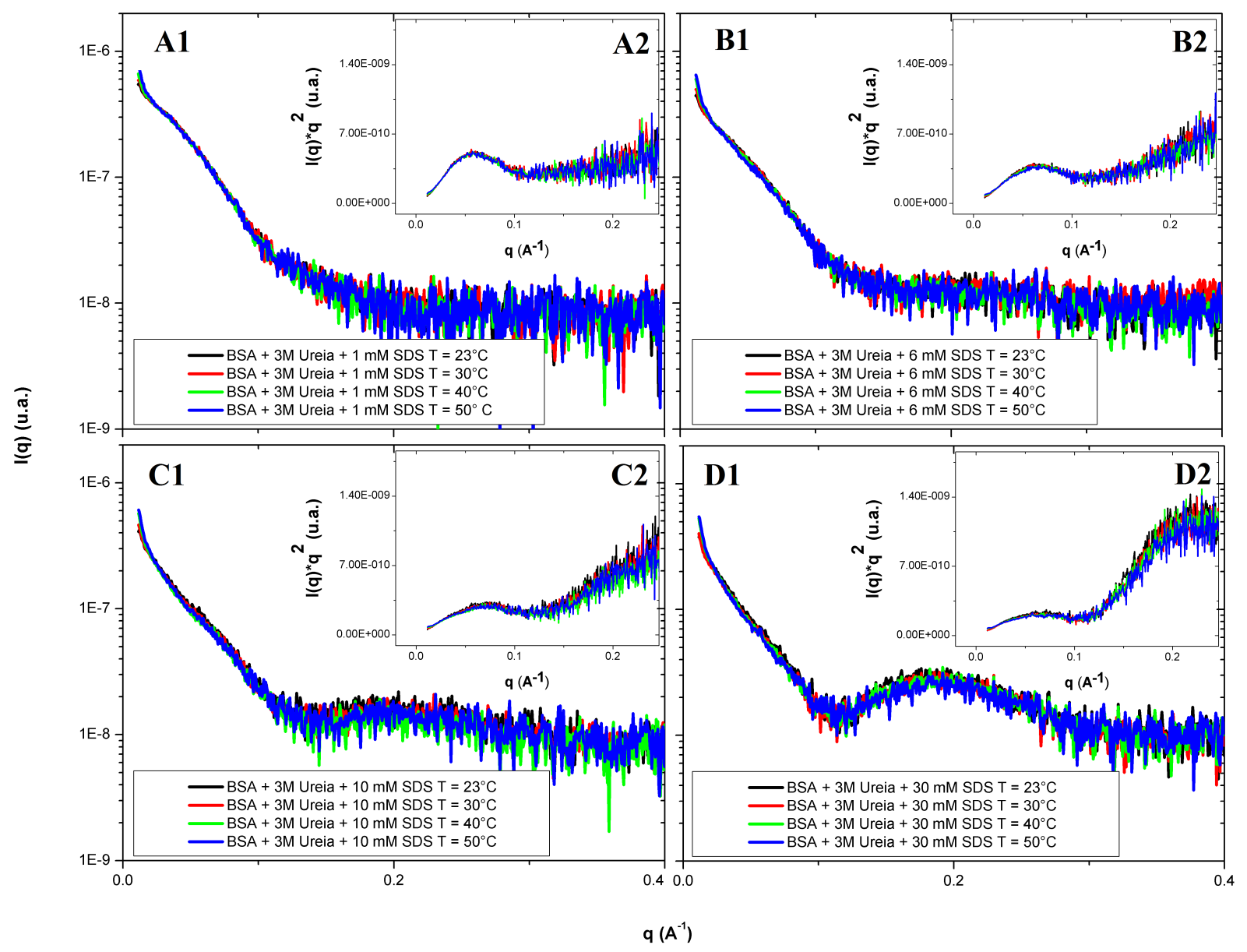

Figura 3.20: Curvas de SAXS para BSA, pH 7.0, a temperatura variável de $23^{\circ} \mathrm{C}$ a $50^{\circ} \mathrm{C}$, na presença de $3 \mathrm{M}$ de uréia e SDS em concentração igual a (A) $1 \mathrm{mM}$, (B) $6 \mathrm{mM}$, (C) 10mM e (D) $30 \mathrm{mM}$. Os destaques nas Figuras mostram as representações de Kratky para as mesmas curvas. 


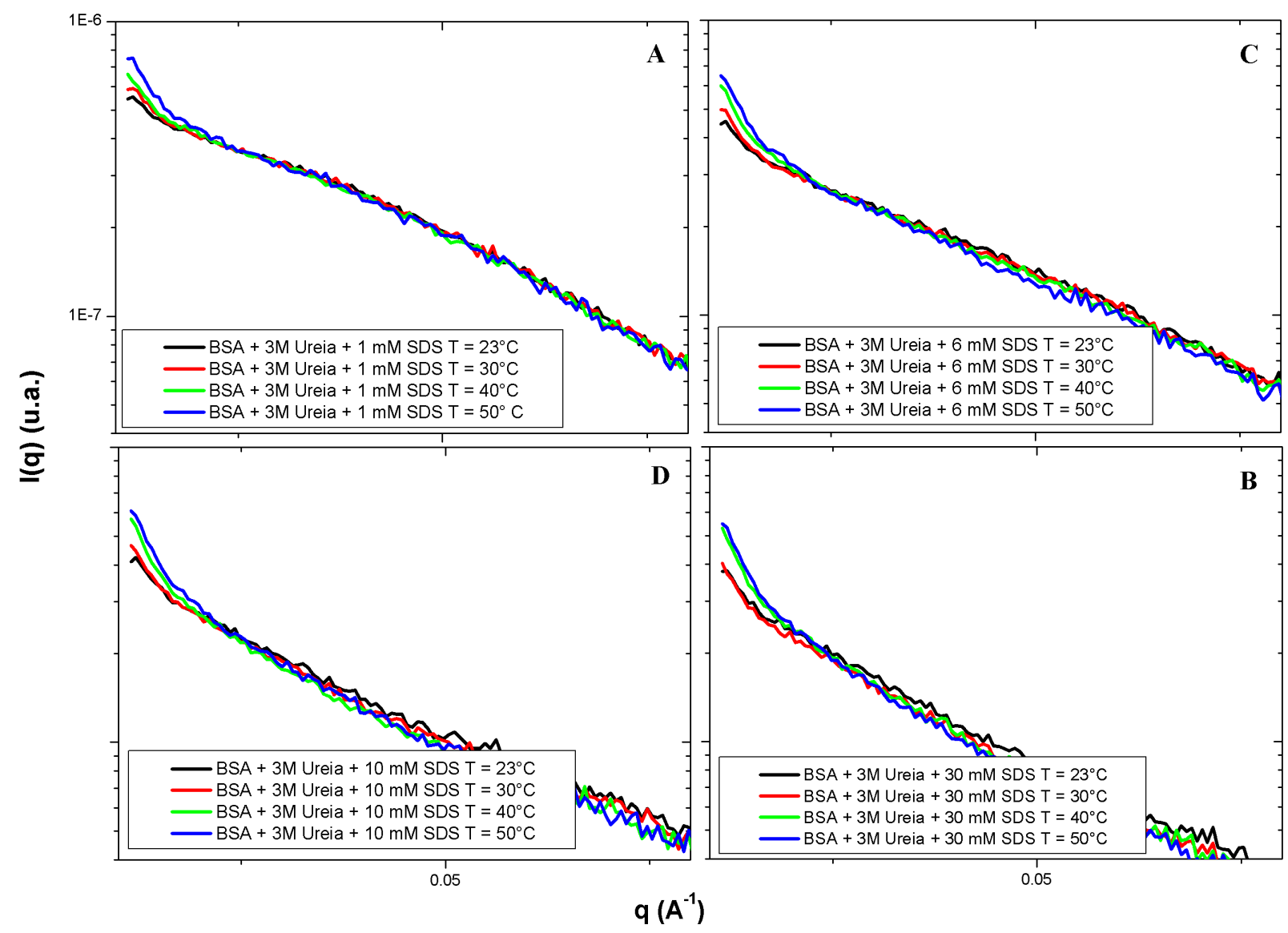

Figura 3.21: Ampliação na região de q pequenos das curvas de SAXS para BSA, pH 7.0, a temperatura variável de $23^{\circ} \mathrm{C}$ a $50^{\circ} \mathrm{C}$, na presença de $3 \mathrm{M}$ de uréia e SDS em concentração igual a (A) $1 \mathrm{mM},(B) 6 \mathrm{mM},(\mathrm{C}) 10 \mathrm{mM}$ e (D) $30 \mathrm{mM}$. 


\subsection{Conclusão}

Para as amostras sem uréia, a presença de até $30 \mathrm{mM}$ de SDS não alterou a conformação da BSA, de maneira que é observada a formação de micelas de SDS coexistindo com a proteína livre em solução. O sistema composto por $50 \mathrm{mM}$ de SDS e BSA foi bem descrito pelo modelo de "colar de pérolas"com uma pequena parcela de BSA livre em solução. Nas amostras contendo BSA, uréia e SDS, o modelo de "colar de pérolas"também se mostrou satisfatório para concentrações acima de $6 \mathrm{mM}$ de SDS.

Com relação ao efeito térmico, observou-se um aumento da agregação dependente da temperatura e da concentração de uréia e SDS, mas sem alteração na conformação. Nos sistemas contendo apenas BSA e SDS, a temperatura de transição para concentrações até $10 \mathrm{mM}$ de SDS foi entre $23^{\circ} \mathrm{C}$ e $30{ }^{\circ} \mathrm{C}$, para $30 \mathrm{mM}$ de SDS a temperatura de transição é entre $30^{\circ} \mathrm{C}$ e $40^{\circ} \mathrm{C}$. Para o conjunto contendo $3 \mathrm{M}$ de uréia a temperatura de transição é ente $40^{\circ} \mathrm{C}$ e $50^{\circ} \mathrm{C}$ para condição onde há $1 \mathrm{mM}$ de $\mathrm{SDS}$ e entre $30^{\circ} \mathrm{C}$ e $40{ }^{\circ} \mathrm{C}$, para concentrações superiores a $6 \mathrm{mM}$ de SDS. Estes resultados indicam que a termoestabilidade da BSA diminui com baixas concentrações de SDS na presença de uréia. 


\section{Capítulo 4}

\section{Estudo da interação das proteínas globu- lares albumina de soro bovina (BSA) e lisozima}

\subsection{Introdução}

Nos últimos anos, tem-se dado cada vez mais atenção ao comportamento de proteínas em condições de altas concentrações macromoleculares, em contraste com as condições de soluções relativamente diluídas historicamente utilizadas para grande parte de estudos biofísicos e bioquímicos. A motivação se deve ao fato que ambientes in vivo apresentam altas concentrações de macromoléculas, o que ocorre também em condições visando a preparação de fármacos proteicos e otimização de condições para crescimento de cristais de proteína 64]. Entre os diversos fatores envolvidos entre os meios tipicamente estudados in vitro e in vivo, a concentração macromolecular é um dos fatores que pode ter grande contribuição para melhor entender-se equilíbrio dos processos de enovelamento e desenovelamento in vivo 65.

O meio intracelular é densamente composto por macromoléculas, com concentração que podem varia de 50 a $400 \mathrm{~g} / \mathrm{L}$. Devido a efeitos de volume excluído, a alta concentração no meio celular aumenta o potencial químico das macromoléculas e, consequentemente, às interações termodinâmicas resultantes 65]. A aglomeração de macromoléculas também afeta a difusão dentro da célula. Assim, interações proteína-proteína, atividades enzimáticas, enovelamento de proteínas e outros processos bioquímicos são modulados de acordo com a 
densidade do meio intracelular 65 .

Os estudo de sistemas com elevadas concentrações consistem em descrever as alterações na estrutura de um complexo de proteínas em função da aglomeração macromolecular, verificar como o equilíbrio entre os estados de enovelamento e desenovelamento são afetados, bem como observar as mudanças estruturais em uma única conformação[66. Para tanto, no que diz respeito a técnica de SAXS, se faz uso de análise de raio de giro, função distribuição de distâncias $p(r)$ e previsão de estrutura, por vezes desconsiderando a utilização de funções de correlação presentes no sistema[66].

Embora de extrema importância, existem muito poucos dados na literatura centrados no problema de interações entre proteínas em sistemas concentrados (conhecido em inglês como "crowding"). Em um trabalho de Goldenberg e Argyle, estes consideraram o modelo simplificado de fluído de esfera dura (função de interação considerando apenas a esfera dura) e mostraram que pode ser aplicado até $400 \mathrm{~g} / \mathrm{L}$ para amostras contendo uma única proteína em solução 64. No caso da BPTI (inibidor da tripsina pancreática básica), proteína estudada por Goldenberg e Argyle, os autores reportaram que não há a formação de dímeros, mas uma interação entre os monômeros. Neste estudo os autores não discutem qual seria o o caráter do potencial de interação entre monômeros, citando apenas que trata-se de um comportamento mais complexo não associado à agregação 64. 
Neste capítulo da tese propomos a utilização da técnica de SAXS estudar o potencial efetivo resultando da interação entre duas proteinas, a concentração total $100 \mathrm{mg} / \mathrm{mL}$, de tamanhos e pesos moleculares distintos. As proteinas utilizadas são a BSA e a lisozima, cujos pesos moleculares são 66,4 kDa e 14,3 kDa, respectivamente, e possuem valores de ponto isoelétrico pI de 5.4 para BSA e 11,0 para lisozima. Portanto, no pH fisiologico estudado aqui, BSA tem carga superficial negativa e lisozima positiva. A estrutura cristalográfica da BSA, código pdb 4F5S, foi anteriormente mostrada na Figura 3.1. Por sua vez, a estrutura cristalográfica da lisozima, código pdb 2CDS, pode ser vista na Figura 4.1 .

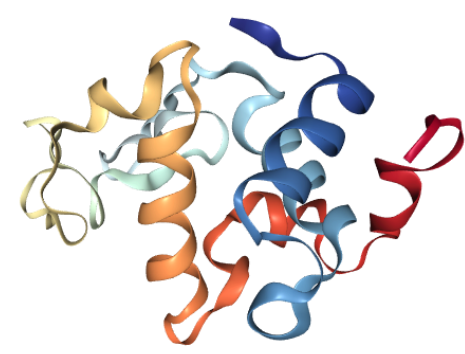

Figura 4.1: Estrutura cristalográfica da lisozima. Imagem gerada utilizando o NGL Viewer[28, 29]. 


\subsection{Objetivos}

\subsubsection{Geral}

Estudar a interação de sistemas não homogêneos, compostos por lisozima e BSA, mantendo uma concentração total de proteínas de $100 \mathrm{~g} / \mathrm{L}$ em solução, com o intuito de avaliar o potencial de interação resultante entre elas em função da variação da razão molar BSA:lisozima.

\subsubsection{Específico}

Utilizar o fator de forma das proteínas combinado a uma função de interferência equivalente única para o sistema, a fim de analisar a interação entre proteínas em amostras contendo concentração variável de lisozima e BSA.

\subsection{SAXS no Laboratório Nacional de Luz Síncrotron (LNLS)}

Os dados experimentais de espalhamento de raio-X a baixos ângulos (SAXS) foram obtidos utilizando a linha de SAXS1 do Laboratório Nacional de Luz Síncroton (LNLS). Cada uma das curvas apresentadas é o resultado de uma tomada de dados com tempo de aquisição de 100 segundos. Apesar da escala arbitrária, todos os dados experimentais foram medidos na mesma campanha, ou seja, mesmo dia e condições experimentais e a temperatura ambiente. Desta forma, a constante experimental é a mesma para todas as curvas apresentadas.

O intervalo do vetor de espalhamento utilizado foi: $0,0127 \leq q \leq 0,2765 \AA^{-1}$. Sendo a dimensão máxima medida pela técnica dada por [15]:

$$
D_{\operatorname{máx}}=\frac{\pi}{q_{\min }}=\frac{\pi}{0,0127} \approx 247 \AA
$$




\subsection{Raio de giro}

Considerando um sistema de proteínas não interagentes, podemos escrever a intensidade de espalhamento como sendo proporcional à forma da partícula espalhadora $P(q)$ tal que [15, 67,

$$
I(q)=k n_{p} P(q)
$$

onde $k$ é uma constante experimental relacionada ao arranjo experimental utilizado e $n_{p}$ é a densidade numérica das partículas.

A função de forma $P(q)$ e, portanto, $I(q)$ para sistemas esfericamente simétricos, pode ser aproximada por uma função exponencial para $q \rightarrow 0$, tal que [18]:

$$
I(q \rightarrow 0)=I(0) e^{-\frac{q^{2} R_{g}^{2}}{3}}
$$

onde $I(0)$ é a intensidade de espalhamento em $q=0$ e $R_{g}$ é o raio de giro da partícula espalhadora, conhecida como Lei de Guinier.

Fazendo um ajuste linear do gráfico de $\ln (I) \times q^{2}$ (gráfico de Guinier [18]), onde $y=$ $A-B q^{2}$, podemos obter $I(0)$ e $R_{g}$ tal que:

$$
\begin{gathered}
I(0)=e^{A} \\
R_{g}=\sqrt{3 B}
\end{gathered}
$$

A aproximação de Guinier vale para a condição que [68, 69].

$$
q R_{g} \leq 1,3
$$

onde $q$ é o último vetor de espalhamento utilizado no ajuste aos pontos experimentais.

No caso de proteínas em solução, o valor de $I(0)$ é diretamente proporcional à massa molecular, de acordo com a Eq. 4.7. Assim, variações no valor de $I(0)$ podem indicar a presença de agregados proteicos no sistema analisado.

$$
M M=\frac{I(0)_{a b s}}{c} \frac{N_{A}}{\Delta \rho^{2} r_{e}^{2} v_{e s p}^{2}}
$$

onde $I(0)_{a b s}$ é a intensidade em escala absoluta, $c$ a concentração da proteína, $N_{A}$ o 
número de Avogadro, $\Delta \rho$ o contraste de densidade eletrônica entre a proteína e o solvente, $r_{e}=0,28 \times 10^{-12} \mathrm{~cm}$ o raio do elétron e $v_{e s p}$ o volume específico da proteína.

\subsubsection{Função distribuição de distâncias}

A função $p(r)$ corresponde à distribuição de distâncias entre elementos espalhadores dentro de uma partícula. Essa função de distribuição de distâncias pode ser obtida calculando-se a transformada inversa da intensidade de espalhamento dada por [15]

$$
p(r)=\frac{1}{2 \pi^{2}} \int_{0}^{\infty} I(q) q r \operatorname{sen}(q r) \mathrm{d} q
$$

A Figura 4.2 mostra padrões de espalhamento típicos e funções distribuição de distâncias correspondentes para corpos geométricos de mesma dimensão máxima. Partículas globulares (curva vermelha), apresentam uma função $p(r)$ no formato de um sino com um máximo de frequências de distâncias internas à partícula em $D_{\text {máx }} / 2$. Partículas alongadas tem distribuições com máximo correspondente ao raio da secção transversal (curva verde). Partículas achatadas apresentam uma função $p(r)$ com um máximo mais alargado (curva amarela), também deslocada para distâncias menores que $D_{m a ́ x} / 2$. Uma função $p(r)$ com máximo deslocado para distâncias maiores que $D_{\text {máx }} / 2$ é geralmente um indicativo de uma partícula oca (curva azul). Partículas que são compostas por unidades bem separadas apresentam mais de um ponto de máximo na função $p(r)$, sendo o primeiro correspondente às distâncias entre elementos na mesma subunidade e o seguinte indica a separação entre as subunidades (curva rosa) 68.

As funções $p(r)$ foram calculadas utilizando o programa GIFT, desenvolvido por O. Glatter[70]. 

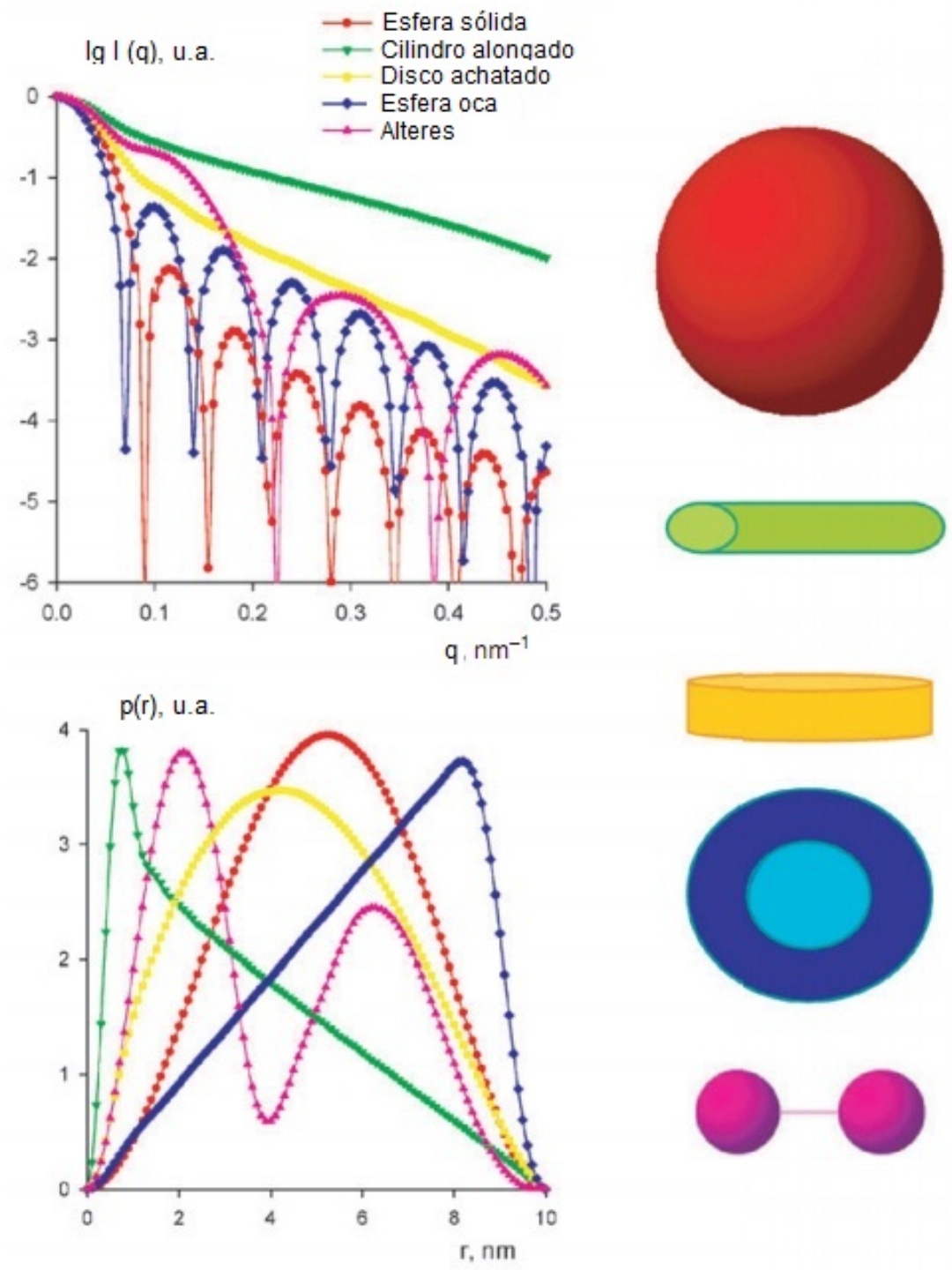

Figura 4.2: Intensidades de espalhamento e funções distribuição de distâncias $p(r)$ de diferentes corpos geométricos. Figura extraída da referência [68]. 


\subsection{Sistemas Interagentes}

É conhecido que a intensidade de espalhamento de raios-X a baixos ângulos, para partículas monodispersas e aleatoriamente distribuidas em uma solução, pode ser escrita como [15],[59]:

$$
I(q)=k n_{p} P(q) S(q)
$$

onde $k$ é fator de normalização associado ao aparato experimental, $n_{p}$ é a densidade de partículas espalhadoras, $S(q)$ é o fator de interferência entre partículas espalhadoras e $P(q)$ é o fator de forma dado por:

$$
P(q)=<|F(q)|^{2}>
$$

Para o sistema contendo alta concentração $(100 \mathrm{mg} / \mathrm{mL})$ de BSA e lisozima, foi utilizada uma função equivalente $S_{e q}(q)$ [37], [17]. Esta abordagem foi adotada por não haver, até o momento, teoria que descreva todas as interações envolvidas em um sistema contendo proteínas diferentes, com tamanhos e cargas diferentes, interagindo entre si considerando interações entre as proteínas do mesmo tipo e interações cruzadas entre proteínas de tipos diferentes. Assim, consideramos que:

$$
I(q)=k\left[n_{\mathrm{BSA}} P_{\mathrm{BSA}}(q)+n_{\text {lisozima }} P_{\text {lisozima }}(q)\right] S_{e q}(q)
$$

onde $k$ é a constante experimental relacionada ao arranjo experimental, $n_{\mathrm{BSA}}$ e $n_{\text {lisozima }}$ são as densidades numéricas de proteínas espalhadoras com os respectivos fatores de forma $P_{\mathrm{BSA}}(q)$ e $P_{\text {lisozima }}(q)$, obtidos a partir das estruturas cristalográficas das proteínas.

A função de interferência equivalente para o sistema, $S_{e q}$, é dada por [62]:

$$
S_{e q}(q)=1+\beta(q)[S(q)-1]
$$

Para este estudo, o fator de acoplamento $\beta(q)$ foi definido pela razão do fator de amplitude de espalhamento média ao quadrado com relação ao fator de amplitude de espalhamento ao quadrado médio de um cilindro hipotético: 


$$
\begin{gathered}
\beta(q)=\frac{\left|<F_{\text {cilindro }}(q)>\right|^{2}}{<\left|F_{\text {cilindro }}(q)\right|^{2}>} \\
F_{\text {cilindro }}(q)=2 \frac{\operatorname{sen}\left(\frac{1}{2} q L \cos \theta\right)}{\frac{1}{2} q L \cos \theta} \frac{J_{1}(q R \operatorname{sen} \theta)}{q R \operatorname{sen} \theta} \\
<F_{\text {cilindro }}(q)>=\int_{0}^{\pi / 2} \operatorname{sen} \theta F_{\text {cilindro }}(q) d \theta \\
<F_{\text {cilindro }}^{2}(q)>=\int_{0}^{\pi / 2} \operatorname{sen} \theta F_{\text {cilindro }}^{2}(q) d \theta
\end{gathered}
$$

onde $R$ e $L$ são o raio e o comprimento do cilindro e $\theta$ é o ângulo formado entre o vetor de espalhamento $q$ e o eixo do cilindro. É importante ressaltar que, neste caso, não está se considerando a existência de um fator de espalhamento com simetria cilíndrica para as proteinas em solução. Os parâmetros do cilindro são utilizados apenas para cálculo de $\beta(q)$. Exemplos deste fator serão apresentados na secção de Resultados.

Para sistemas esfericamente simétricos, $\beta(q)$ é igual a 1 e $S(q)$ é dada por:

$$
S(q)=1+4 \pi n_{\rho} \int r^{2} d r g(r) \frac{\operatorname{sen}(q r)}{q r}
$$

O cálculo de $S(q)$ para proteínas globulares é bem estabelecido, sendo que as metodologias empregadas dependem das condições de contorno para cálculo da função de distribuição radial $g(r)$. Neste caso, foi adotada a Random Phase Approximation (RPA)[71], que é aplicável a sistemas moderadamente concentrados de esferas com carga superficial limitada. O potencial de interação é tratado como uma perturbação do potencial de referência (o de esfera dura, também chamado de volume excluído), cujo fator de estrutura correspondente, $\mathrm{S}_{0}(\mathrm{q})$ é dado por Hansen e McDonald[72]. Para maiores detalhes ver referência [62].

O potencial de interação entre proteínas utilizado é o descrito por Narayanan e Liu, que combina o potencial eletrostático de Coulomb e o potencial atrativo do tipo Yukawa[73]. O potencial do tipo Yukawa é um potencial efetivo, que leva em conta as contribuições de potenciais tais como o potencial de van der Waals e osmótico.

Desta forma, o potencial de interação entre proteínas, pode ser escrito como:

$$
V(r)=V_{H S}(r)+V_{C}(r)+V_{Y}(r)
$$


onde $V_{H S}$ é o potencial de esfera dura, dado por:

$$
V_{H S}(r)=\left\{\begin{array}{lll}
\infty & \text { para } & r<\sigma_{\text {ef }} \\
0 & \text { para } & r \geq \sigma_{\text {ef }}
\end{array}\right.
$$

onde $\sigma_{\text {ef }}$ é o parâmetro de ajuste do diâmetro efetivo da esfera dura.

$V_{C}(r)$ é o potencial coulombiano, dado por:

$$
V_{C}(r)=\frac{Z^{2} e^{2}}{\epsilon\left(1+(1 / 2) k \sigma_{\mathrm{ef}}\right)^{2}} \frac{e^{-k\left(r-\sigma_{\mathrm{ef}}\right)}}{r}
$$

sendo $Z$ a carga efetiva da proteína em solução, $e$ a carga do elétron, $\epsilon$ a constante dielétrica do solvente e

$$
k=\sqrt{\frac{8 \pi e^{2} N_{A} I}{\epsilon k_{B} T}}
$$

onde $N_{A}$ é o número de Avogadro, $T$ a temperatura e $I$ é a força iônica total. Por sua vez, $I$ é a soma dos contraíons da proteína, $I_{c}=(1 / 2) n_{p}|Z|$ e a força iônica devido aos sais dos componentes do tampão utilizado $I_{S}$. No caso do estudo aqui apresentado, $I_{s}=20 \mathrm{mM}$.

Por fim, o potencial Yukawa atrativo é descrito por:

$$
V_{Y}(r)=-J\left(\frac{\sigma_{e f}}{r}\right) e^{\frac{-\left(r-\sigma_{\text {ef }}\right)}{d}}
$$

onde $d$ é o alcance do potencial atrativo e $J$ a profundidade do potencial em $r=\sigma_{e f}$

Os ajustes do modelo às curvas experimentais foram feitas utilizando-se o programa GENFIT [16], [17], desenvolvido pelo Prof. Francesco Spinozzi. Os parâmetros de ajuste utilizados foram: a densidade eletrônica relativa da camada de hidratação do modelo da estrutura cristalográfica com relação ao solvente, $d_{c o r}$; a profundidade do potencial $J$; o alcance do potencial atrativo, $d$; o módulo da carga efetiva da proteína em solução $|Z|$; o diâmetro efetivo da esfera dura $\sigma_{\text {ef }}$ e o raio $R$ e o comprimento $L$ do cilindro utilizados para cálculo de $\beta(q)$. 
Tabela 4.1: Composição das amostras de BSA e lisozima.

\begin{tabular}{c|c|c}
\hline Razão molar BSA:LISO & Porcentagem em peso de BSA & Porcentagem em peso de lisozima \\
\hline $1: 0$ & $100 \%$ & $0 \%$ \\
$1: 0,5$ & $90 \%$ & $10 \%$ \\
$1: 1,2$ & $80 \%$ & $20 \%$ \\
$1: 2$ & $70 \%$ & $30 \%$ \\
$1: 3$ & $60 \%$ & $40 \%$ \\
$1: 5$ & $50 \%$ & $50 \%$ \\
$1: 7$ & $40 \%$ & $60 \%$ \\
$1: 11$ & $30 \%$ & $70 \%$ \\
$1: 19$ & $20 \%$ & $80 \%$ \\
$1: 42$ & $10 \%$ & $90 \%$ \\
$0: 1$ & $0 \%$ & $100 \%$ \\
\hline
\end{tabular}

\subsection{Amostras}

Foram analisadas amostras de BSA e lisozima em tampão acetato-fosfato-borato de sódio $(20 \mathrm{mM})$. Todas as amostras possuem uma concentração total final de $100 \mathrm{mg} / \mathrm{mL}$ de proteínas em solução. As amostras foram preparadas a partir de duas soluções iniciais de $100 \mathrm{mg} / \mathrm{mL}$ de BSA e de lisozima, retirando-se alíquotas de cada uma delas de modo a formar novas soluções contendo uma porcentagem variável que corresponde de 0\% a 100\%, com variações de 10\%, da solução final. Para apresentação e discussão dos resultados, foi feito o cálculo da razão molar da lisozima com relação a BSA, conforme mostrado na Tabela 4.1. 


\subsection{Resultados e Discussão}

Na Figura 4.3 estão representadas as curvas de SAXS para as amostras contendo BSA e lisozima, variando a proporção de monômeros de lisozima em relação a BSA de 1 monômero de BSA para 0,5 monômero de lisozima (razão molar BSA:LISO 1:0,5) até a proporção de 1 monômero de BSA para 42 de lisozima (BSA:LISO 1:42).

Para uma melhor visualização dos dados experimentais, a Figura 4.4. A mostra as curvas de BSA:LISO de 1:0,5 a 1:5. A linha contínua vermelha indica o fator de forma $\mathrm{P}(\mathrm{q})$ da BSA obtido a partir da estrutura cristalográfica da BSA (código pdb 4F5S), para efeito de comparação. De maneira análoga, na Figura 4.4.B estão os resultados das amostras com BSA:LISO de 1:5 a 1:42. A linha contínua cinza indica o fator de forma $\mathrm{P}(\mathrm{q})$ da lisozima obtido a partir da estrutura cristalográfica da lisozima (código pdb 2CDS). É possível observar que, com o aumento da proporção de monômeros de lisozima em relação à BSA, até a proporção de BSA:LISO 1:5 há um aumento da intensidade de espalhamento principalmente na região de $q \leq 0,05 \AA^{-1}$. A partir de BSA:LISO 1:5, a intensidade nesta região de $q$ diminui. Foi considerada a possibilidade do aumento da intensidade estar correlacionada com a formação de agregados ou com um potencial de interação entre proteínas de caráter predominantemente atrativo. Ambas possibilidades serão discutidas mais a frente. 


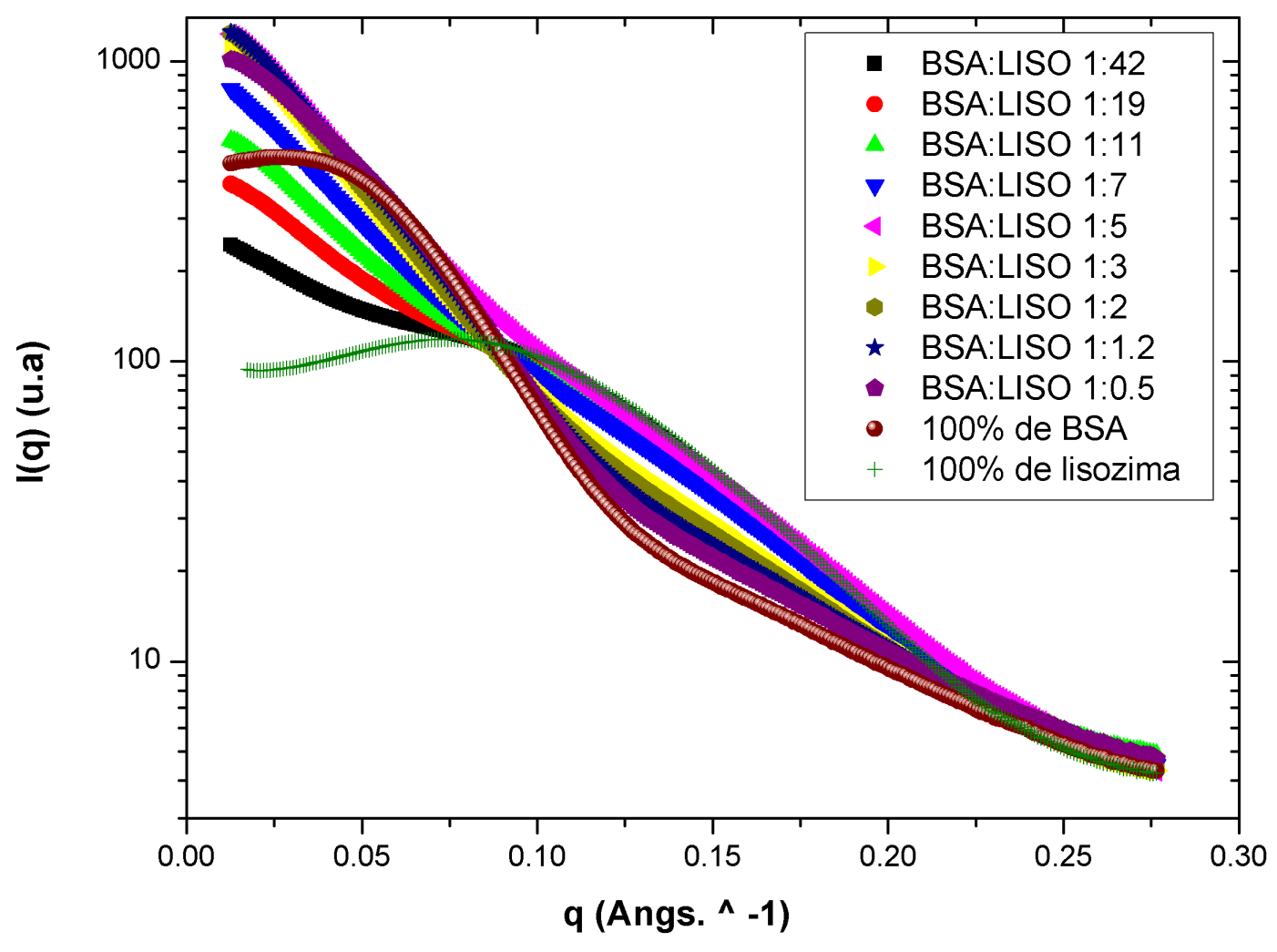

Figura 4.3: Curvas de SAXS para BSA e Lisozima a $\mathrm{T}=23^{\circ} \mathrm{C}, \mathrm{pH}$ 7.0, variando-se a razão molar BSA:lisozima, conforme especificado na legenda. 
Estudo da interação das proteínas globulares albumina de soro bovina (BSA) e 104

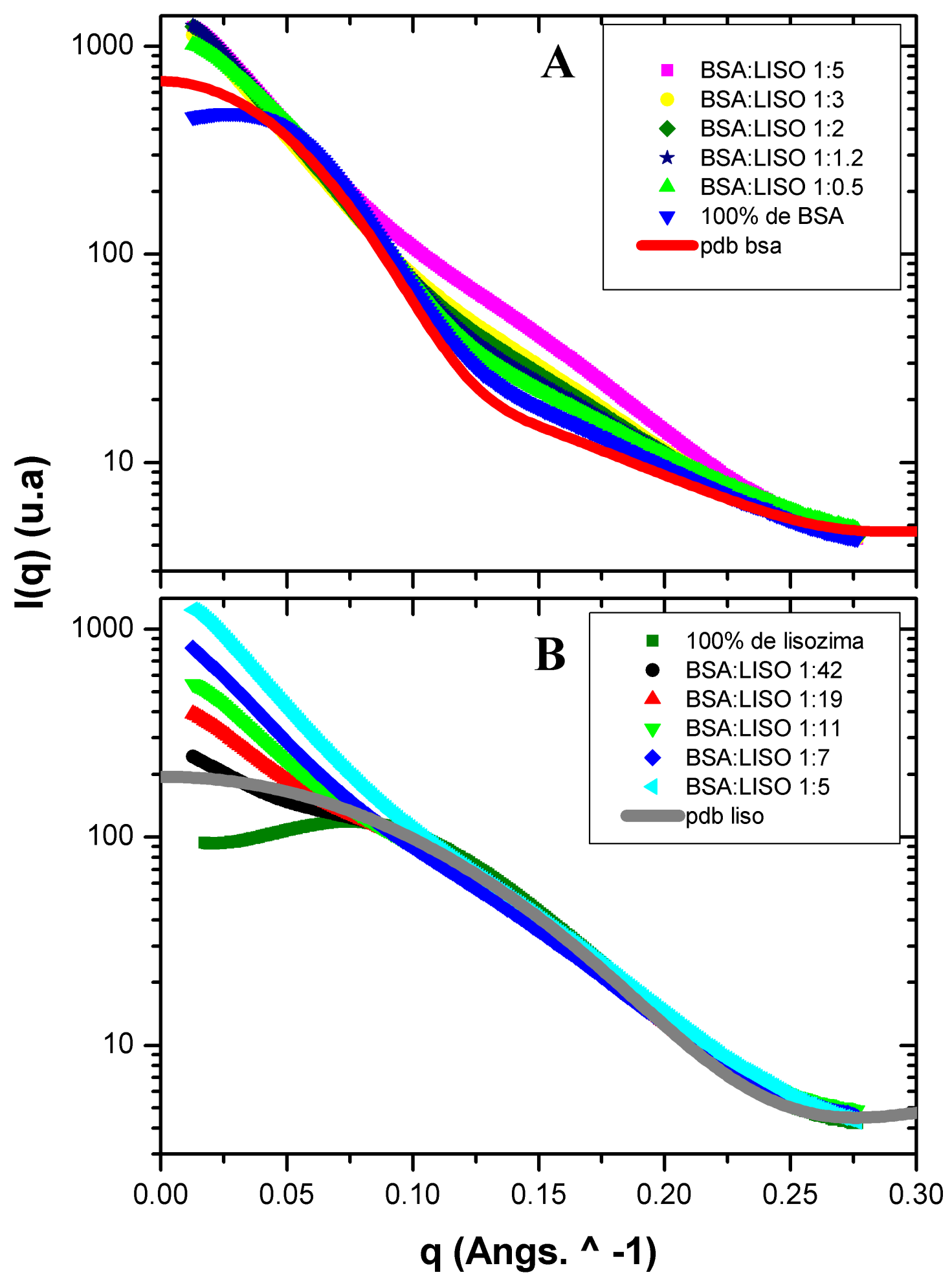

Figura 4.4: Curvas de SAXS para BSA e Lisozima a $\mathrm{T}=23^{\circ} \mathrm{C}, \mathrm{pH}$ 7.0. (A) $100 \%$ de BSA e BSA:LISO de 1:0,5 até 1:5. A linha contínua vermelha indica o fator de forma $P(q)$ da BSA obtido a parir da estrutura cristalográfica da BSA (código pdb 4F5S); (B) 100\% de lisozima e BSA:LISO de 1:5 até 1:42. A linha contínua cinza indica o fator de forma $\mathrm{P}(\mathrm{q})$ da lisozima obtido a parir da estrutura cristalográfica da lisozima (código pdb 2CDS). 


\subsection{Análise Inicial}

$\mathrm{O}$ raio de giro e intensidade em $q \rightarrow 0, \mathrm{I}(0)$, foram calculadas conforme descrito na Secção 4.4. Conforme mostrado nas Figuras 4.5 e 4.6, os dois parâmetros diminuem a partir da proporção BSA:LISO 1:5. Vale a pena ressaltar que a análise do raio de giro e I(0) só é possível no caso de não haver interações entre as proteínas, portanto, questionáveis no nosso caso.

Na Figura 4.7 estão as funções de distribuição de distâncias $p(r)$ para todas as amostras. Para uma melhor visualização, na Figura 4.8. A estão as curvas até BSA:LISO 1:5 e na Figura 4.8.B, a partir de BSA:LISO 1:5. Na Figura 4.8. A podemos observar que a função $p(r)$ para a amostra pura de BSA apresenta valores negativos com mínimo em torno de $75 \AA$. Tal resultado indica a presença de uma função de interação entre proteínas que pode também ser identificado na curva de SAXS correspondente na Figura 4.4.A (pico de correlação em torno de $0,05 \AA^{-1}$, Figura 4.4.A). Conforme veremos na análise mais aprofundada adiante, tal pico é associado a um potencial de interação de caráter repulsivo de esfera dura somado ao potencial coulombiano (efeito de cargas na superfície da proteína) 62. Note que a presença de 1 lisozima para 2 moléculas de BSA (razão BSA:LISO 1:0,5) atenua este pico (Figura 4.4.A), sendo refletido na ausência de valores negativos da função $p(r)$ (Figura 4.8.A). Ressalta-se aqui que no pH estudado BSA tem carga superficial negativa e lisozima positiva. Portanto, devem estar ocorrendo alterações no potencial repulsivo entre proteínas.

Com o aumento da proporção de lisozima com relação a BSA, verifica-se que o mínimo da $\mathrm{p}(\mathrm{r})$ na região de $r \approx 75 \AA$ é mais atenuado ainda. Concomitantemente, a dimensão máxima aumenta e a forma de sino, com pico observado ao redor de $r \approx 30 \AA$, é alargado. Esse comportamento ocorre até a proporção BSA:LISO 1:5. A partir desta proporção, verifica-se que o formato de sino, passa a ter dois picos, diminuindo de intensidade com o aumento da concentração de lisozima. Conforme a lisozima passa a ser predominante na amostra, a função $p(r)$ começa a se assemelhar à obtida para a amostra contendo apenas lisozima (Figura 4.8.B).

Novamente, a função $p(r)$ para solução contendo apenas lisozima possui um vale negativo, indicando um potencial de interação repulsivo entre lisozimas. Tais resultados da $p(r)$, raio de giro e $I(0)$, indicaram uma possível análise utilizando uma abordagem que consideraria a formação de agregados elipsoidais ou cilíndricos, devido a atração entre as proteínas, 
coexistindo com a BSA e lisozima livres em solução. Apesar dos ajustes obtidos serem satisfatórios, conforme pode ser visto no Apêndice A, o agregado elipsoide se mantém com as mesmas dimensões com o aumento da porcentagem da lisozima, aumentando apenas a contribuição para a intensidade do espalhamento. De acordo com os resultados de $p(r)$, seria esperado que o agregado aumentasse de tamanho com o aumento da concentração de lisozima, até a razão BSA:LISO 1:5. A partir da razão BSA:LISO 1:7, os agregados diminuiriam de tamanho (Figuras 4.5, 4.6 e 4.8.B). Desta forma, pela incongruência nas análises de $p(r)$, raio de giro e $\mathrm{I}(0)$, , descartou-se esta abordagem apesar dos bons ajustes das curvas experimentais. Além da abordagem utilizando o modelo de elipsoide, também foram feitas tentativas de ajustes apenas com as estruturas cristalográficas das proteínas e outra, ainda, com o modelo de agregado cilíndrico, que também não foram adequadas para descrever as curvas experimentais.

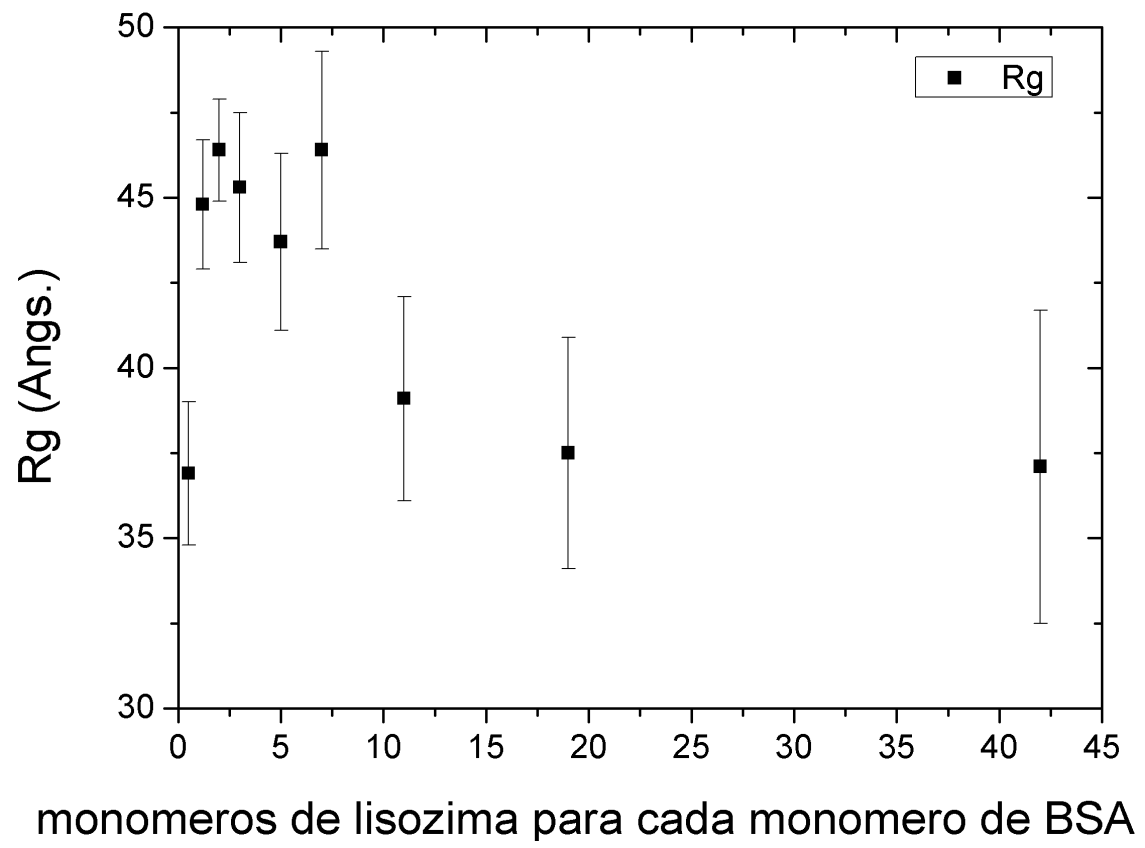

Figura 4.5: Raio de giro em função do número de monômeros de lisozima para cada monômero da BSA. 


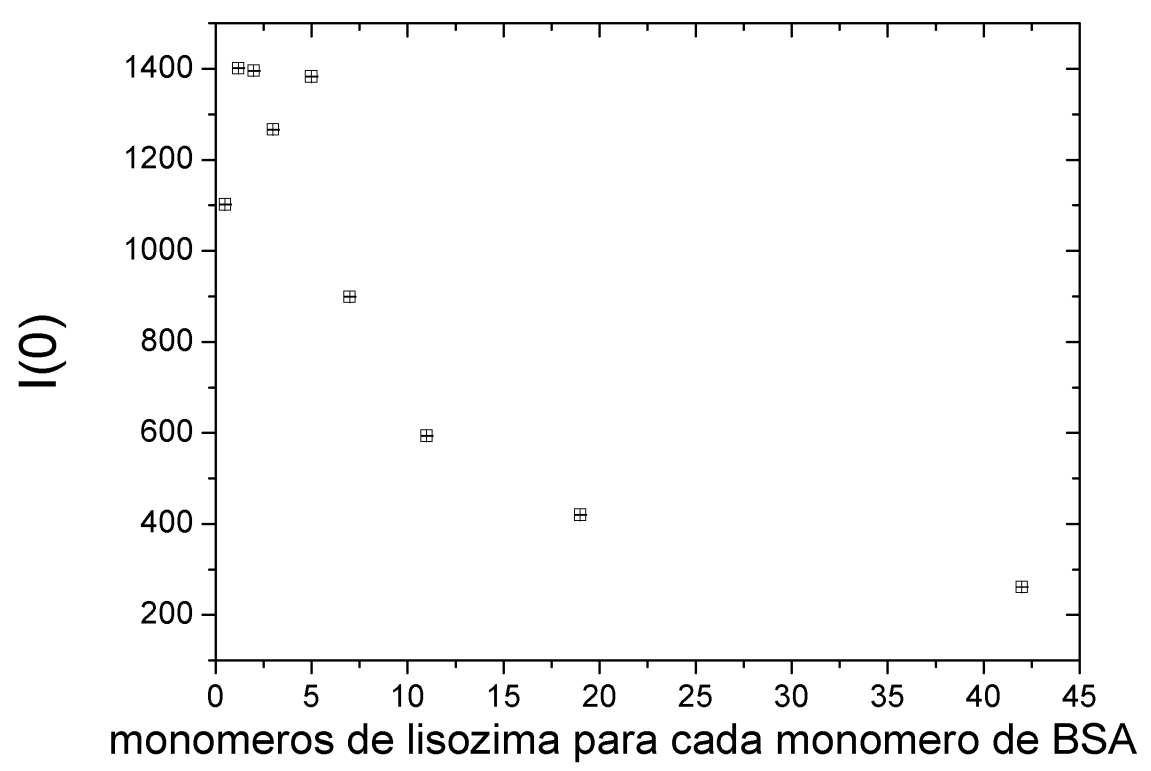

Figura 4.6: Intensidade de espalhamento em $q \rightarrow 0$, I(0), em função do número de monômeros de lisozima para cada monômero da BSA.

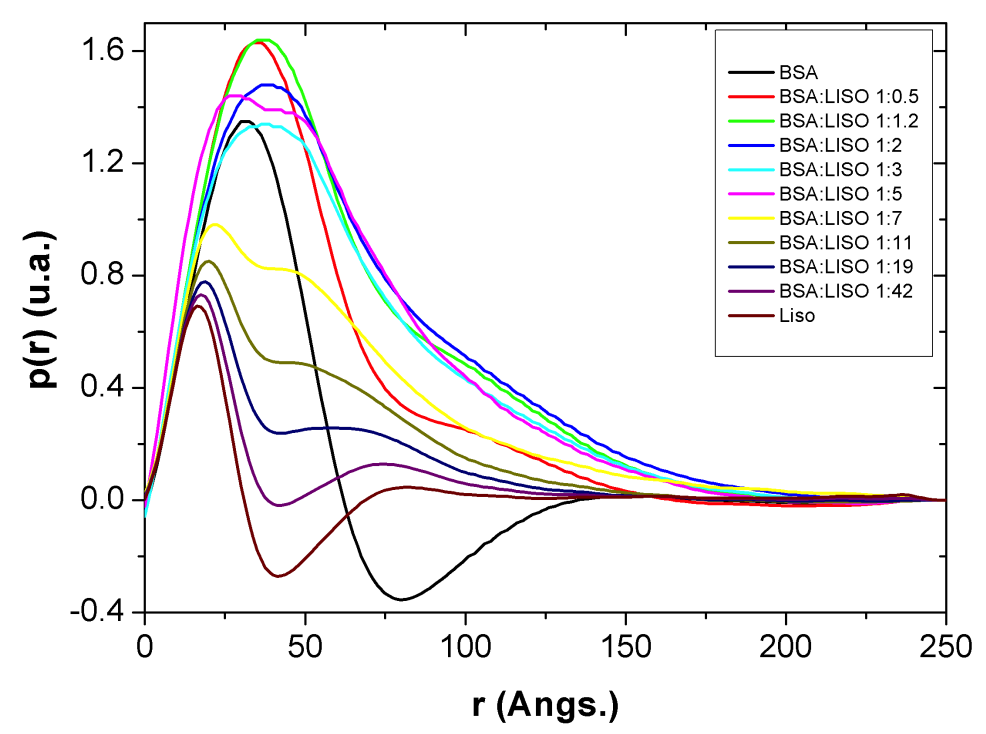

Figura 4.7: Funções distribuições de distâncias, p(r), para BSA:LISO 1:0,5 a BSA:LISO 1:42, 100\% BSA e 100\% lisozima. 
Estudo da interação das proteínas globulares albumina de soro bovina (BSA) e 108

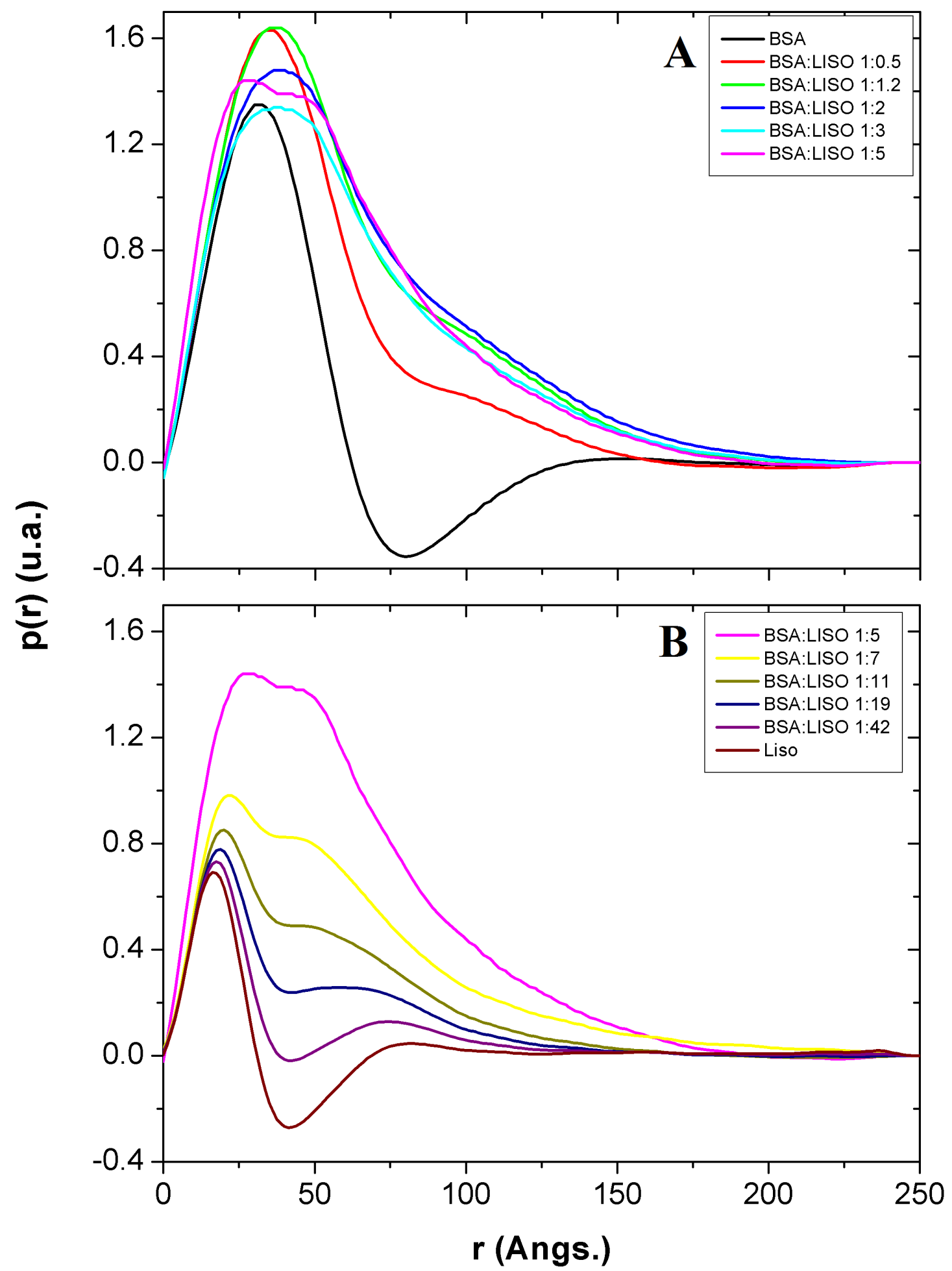

Figura 4.8: Funções distribuições de distâncias, p(r), (A) 100\% de BSA e BSA:LISO de 1:0,5 até 1:5; (B) 100\% de lisozima e BSA:LISO de 1:5 até 1:42. 


\subsection{Análise considerando um potencial de interação inter- proteinas}

Tendo como base as discussões realizadas a partir da análise inicial, optou-se por analisar este conjunto de amostras considerando uma função de correlação equivalente para o sistema composto por lisozima e BSA, utilizando-se uma função equivalente $S_{e q}(q)$, conforme descrito na Seç̧ão 4.5. Foi verificado inicialmente se a utilização de uma $S(q)$ equivalente para o sistema ajustaria satisfatoriamente as curvas das amostras contendo apenas BSA e apenas lisozima. De fato, como é visto na Figura 4.9, a abordagem utilizada ajusta as curvas de BSA e lisozima com parâmetros compatíveis aos obtidos em trabalhos anteriores em condições semelhantes 62. A Figura 4.10 mostra o efeito da utilização do fator de acoplamento $\beta(q)$ (curva em vermelho) e da função $S(q)$ (curva azul) na função resultante $S_{e q}(q)$ (curva em preto). Os parâmetros obtidos estão na Tabela 4.2.

Conforme podemos observar, o sistema composto por $100 \mathrm{mg} / \mathrm{mL}$ de BSA possui um potencial de interação atrativo, com valores de profundidade de poço de potencial de 5,5 KbT e alcance de cerca de $13 \AA$, que se combina com um potencial de Coulomb de caráter repulsivo de uma esfera com carga superficial efetiva de -11 e. De maneira similar, lisozimas a $100 \mathrm{mg} / \mathrm{mL}$ também apresentam um poço de potencial atrativo de profundidade $4 \mathrm{KbT}$ e alcance de $13 \AA$, combinado a uma força eletrostática de Coulomb entre esferas carregadas positivamente (carga efetiva de +9 e). Em ambos os casos, o potencial efetivo resultante (Eq. 4.18) tem caráter repulsivo, conforme veremos nas Figuras 4.18 e 4.19 adiante. 
Tabela 4.2: Parâmetros dos ajustes experimentais para as amostras de BSA e lisozima. São eles: densidade eletrônica relativa da camada de hidratação do modelo da estrutura cristalográfica com relação ao solvente, $d_{\text {cor }}$; profundidade do potencial $J$; alcance do potencial atrativo, $d$; módulo da carga efetiva da proteína em solução $|Z|$; diâmetro efetivo da esfera dura $\sigma_{\text {ef }}$ e raio $R$ e comprimento $L$ do cilindro utilizados para cálculo de $\beta(q)$.

\begin{tabular}{c|ccccccccccc}
\hline BSA:LISO & $\mathrm{BSA}$ & $1: 0,5$ & $1: 1,2$ & $1: 2$ & $1: 3$ & $1: 5$ & $1: 7$ & $1: 11$ & $1: 19$ & $1: 42$ & LISO \\
\hline $\mathrm{d}_{\text {cor }}$ & $1,00(1)$ & $1,02(1)$ & $1,03(2)$ & $1,09(1)$ & $1,02(2)$ & $1,00(1)$ & $1,02(2)$ & $1,02(1)$ & $1,00(2)$ & $1,02(1)$ & $1,02(1)$ \\
$\mathrm{J}\left(k_{B} T\right)$ & $5,5(5)$ & $5,6(6)$ & $6,8(1)$ & $7,5(1)$ & $3(1)$ & $1,6(1)$ & $1,3(1)$ & $1,5(2)$ & $1,1(1)$ & $0,9(1)$ & $4,0(6)$ \\
$\mathrm{d}(\AA)$ & $13,3(4)$ & $3,7(3)$ & $3,8(2)$ & $4,3(1)$ & $8(2)$ & $11,7(4)$ & $13,3(6)$ & $14,7(3)$ & $17(1)$ & $21,7(4)$ & $13,2(1)$ \\
$|Z|(e)$ & $11(1)$ & $0,1(4)$ & $0,1(4)$ & $0,3(1)$ & $0,2(1)$ & $0,8(1)$ & $0,8(4)$ & $3,1(5)$ & $2,9(3)$ & $3,6(2)$ & $9(1)$ \\
$\sigma_{\text {efetivo }}(\AA)$ & $40,5(4)$ & $45(2)$ & $45(1)$ & $46,4(5)$ & $37(2)$ & $37,0(2)$ & $36(1)$ & $35,7(4)$ & $34(1)$ & $31,9(5)$ & $27,3(2)$ \\
conc $\left(\times 10^{-3} \mathrm{M}\right)$ & 1,51 & 2,05 & 2,60 & 3,15 & 3,70 & 4,25 & 4,80 & 5,35 & 5,89 & 6,44 & 6,99 \\
$L_{\beta}$ & $40,6(1)$ & $32(2)$ & $35(1)$ & $39(1)$ & $37(3)$ & $32(1)$ & $35(2)$ & $39(1)$ & $41(2)$ & $44(1)$ & $42,9(5)$ \\
$R_{\beta}$ & $29(1)$ & $21(5)$ & $10(3)$ & $12(1)$ & $10(4)$ & $32(5)$ & $21(4)$ & $10(1)$ & $12(4)$ & $1(6)$ & $20(1)$ \\
fundo (u.a.) & $1,02(4)$ & $2,1(2)$ & $2,0(1)$ & $2,5(1)$ & $1,8(2)$ & $4,0(1)$ & $1,9(1)$ & $1,4(2)$ & $1,0(2)$ & $1,2(1)$ & $0,9(1)$ \\
\hline
\end{tabular}


A Figura 4.11 mostra um exemplo de ajuste da curva experimental do sistema BSA:LISO 1:7 utilizando com os modelos das estruturas cristalográficas da BSA (código pdb 4F5S) e lisozima (código pdb 2CDS), com a função de interferência equivalente $S_{\text {eq }}(q)$. A Figura 4.12 mostra o efeito da utilização do fator de acoplamento $\beta(q)$ (curva em vermelho) e da função $S(q)$ (curva azul) na função resultante $S_{e q}(q)$ (curva em preto). É possível verificar que o principal efeito do fator de acoplamento é a suavização da $S(q)$ para $q \geq \AA^{-1}$, aproximando $S_{e q}=1$ para $q \geq 0,13 \AA^{-1}$. Esse efeito ocorre para todas as amostras analisadas utilizando o fator de acoplamento $\beta(q)$.

Os melhores ajustes obtidos para todas as curvas contendo BSA e lisozima são mostrados nas Figuras 4.13, 4.14 e 4.15. Os parâmetros obtidos através dos ajustes estão na Tabela 4.2 . Verifica-se que valor absoluto da carga decresce de 11 elétrons para BSA pura para 0,1 (nula) quando 1 macromolécula de lisozima coexiste com duas de BSA (razão molar BSA:LISO de 1:0,5) e 6 macromoléculas de lisozima coexistem com 5 de BSA (razão molar BSA:LISO de 1:1,2) (Tabela 5.2). Portanto, nestas condições, podemos observar uma blindagem efetiva das cargas, o que diminui a contribuição do potencial repulsivo entre as proteínas. Ao mesmo tempo, a profundidade do poco de potencial atrativo efetivo se mantém mas diminui seu alcance (Tabela 4.2).

Já para adições maiores de lisozima ao sistema (razão molar BSA:LISO 1:11 até 1:42) a carga efetiva volta a aumentar ( $\mathrm{Z}$ em torno de 3 a 3,6) provavelmente devido a grande quantidade de lisozima já presente em solução, mas a profundidade de poço de potencial atrativo decresce (Tabela 4.2). O diâmetro efetivo $\sigma_{\text {efetivo }}$ tem seu valor diminuido conforme a concentração de lisozima aumenta, indo de 45 Åaté 32 Åde BSA:LISO 1:0,5 a 1:42. O comportamento oposto é observado para o alcance do potencial $d$ que aumenta de 3,7 $\AA$ (BSA:LISO 1:0,5) até 21,7 A para razão BSA:LISO 1:42. A densidade eletrônica relativa da camada de hidratação $\mathrm{d}_{\text {cor }}$ não apresentou alterações significativas com a variação da razão BSA:LISO. Note que, conforme mencionado anteriormente neste capítulo, os valores de $L_{\beta}$ e $R_{\beta}$ não se referem a um cilindro em solução. Estes parâmetros são apenas utilizados para o cálculo da função $\beta(q)$, que pondera a $S_{e q}(q)$. 
Estudo da interação das proteínas globulares albumina de soro bovina (BSA) e 112

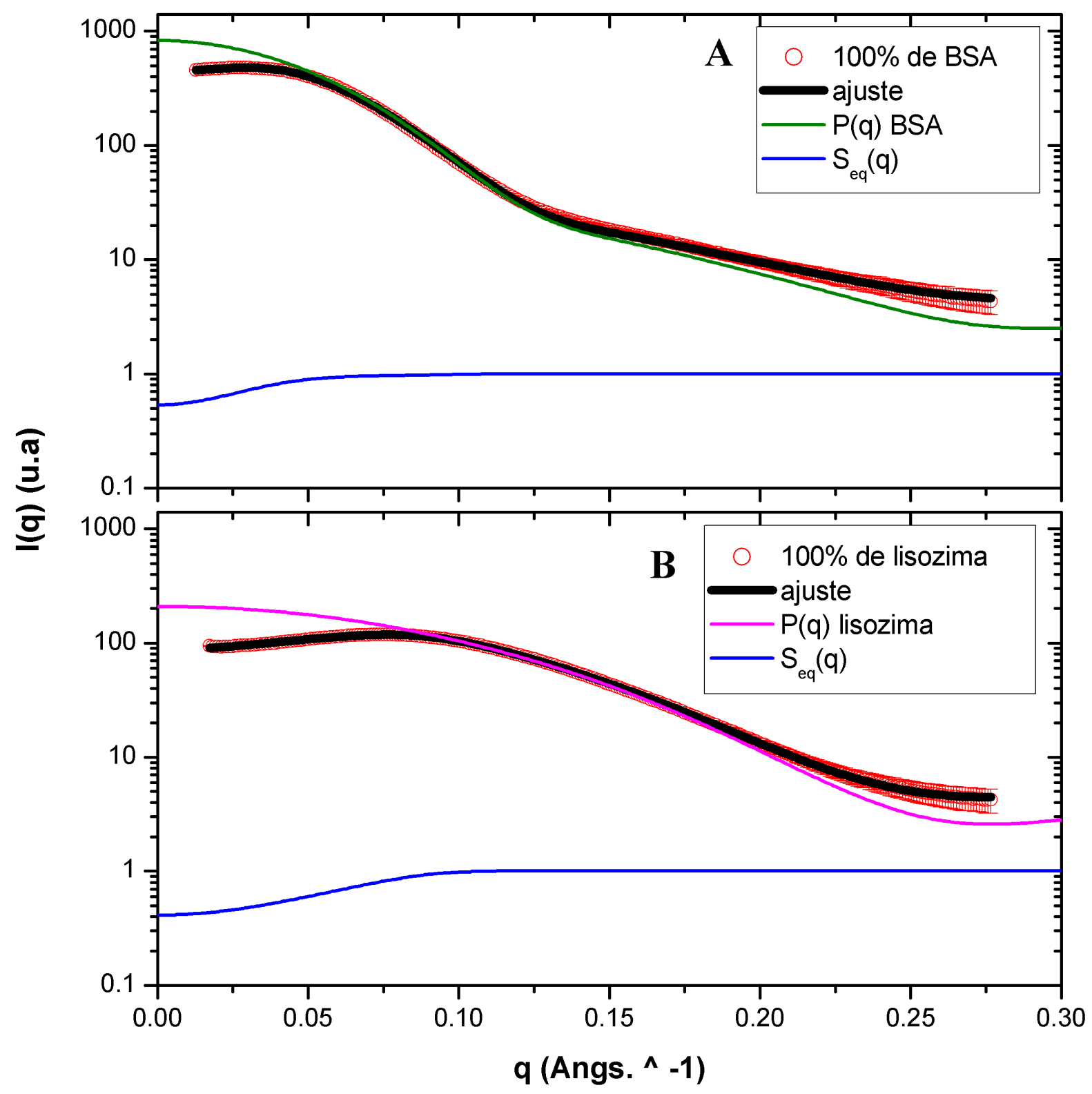

Figura 4.9: Melhores ajustes das curvas de SAXS para (A) BSA $100 \mathrm{mg} / \mathrm{mL}$ e (B) lisozima $100 \mathrm{mg} / \mathrm{mL}$ a $\mathrm{T}=23^{\circ} \mathrm{C}, \mathrm{pH} 7.0$. 


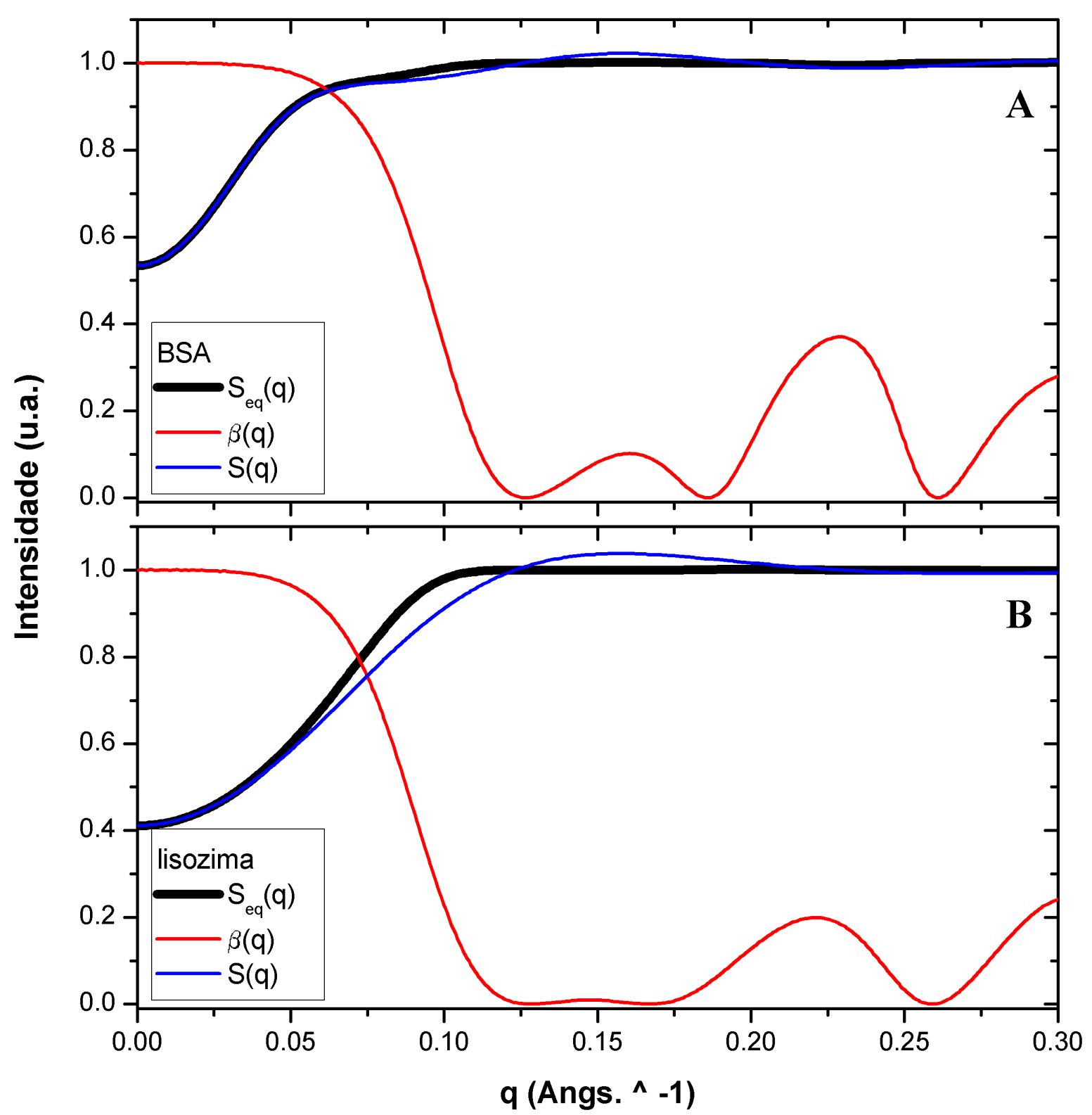

Figura 4.10: Influência do fator de acoplamento $\beta(q)$ na função de interferência $S_{e q}(q)$ utilizada no ajuste da curva de SAXS (A) BSA $100 \mathrm{mg} / \mathrm{mL}$ e (B) lisozima $100 \mathrm{mg} / \mathrm{mL}$ a $\mathrm{T}=23^{\circ} \mathrm{C}, \mathrm{pH} 7.0$. 
Estudo da interação das proteínas globulares albumina de soro bovina (BSA) e 114

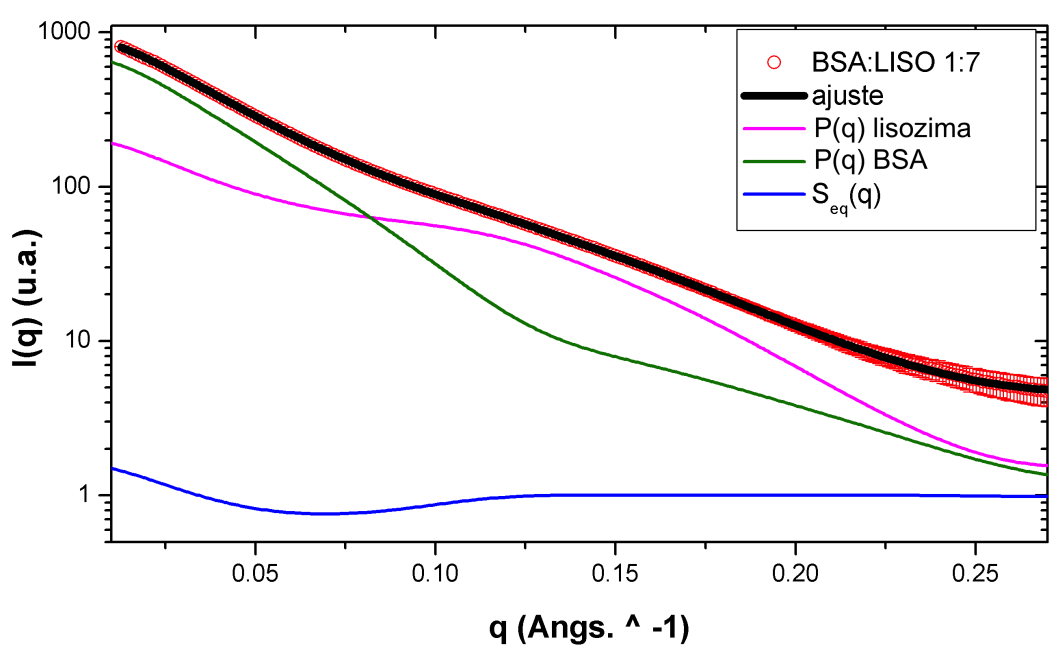

Figura 4.11: Exemplo de ajuste da curva de SAXS para proporção de monômeros BSA:LISO $1: 7$.

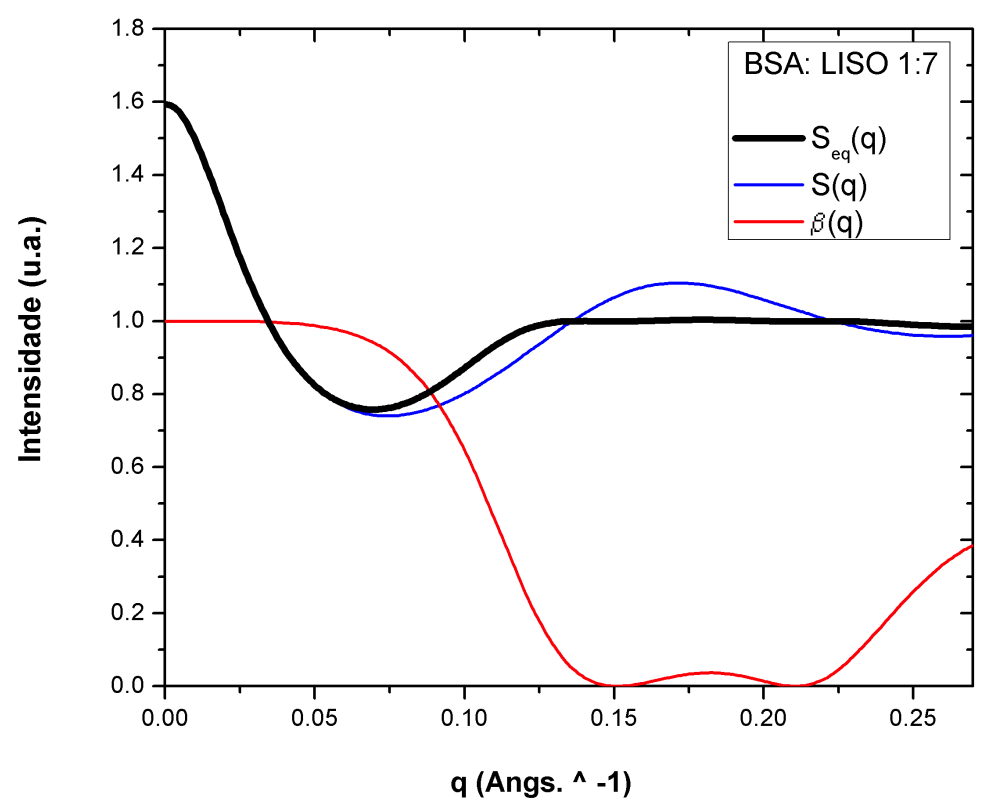

Figura 4.12: Exemplo da influência do fator de acoplamento $\beta(q)$ na função de interferência $S_{e q}(q)$ utilizada no ajuste da curva de SAXS para proporção de monômeros BSA:LISO 1:7. 


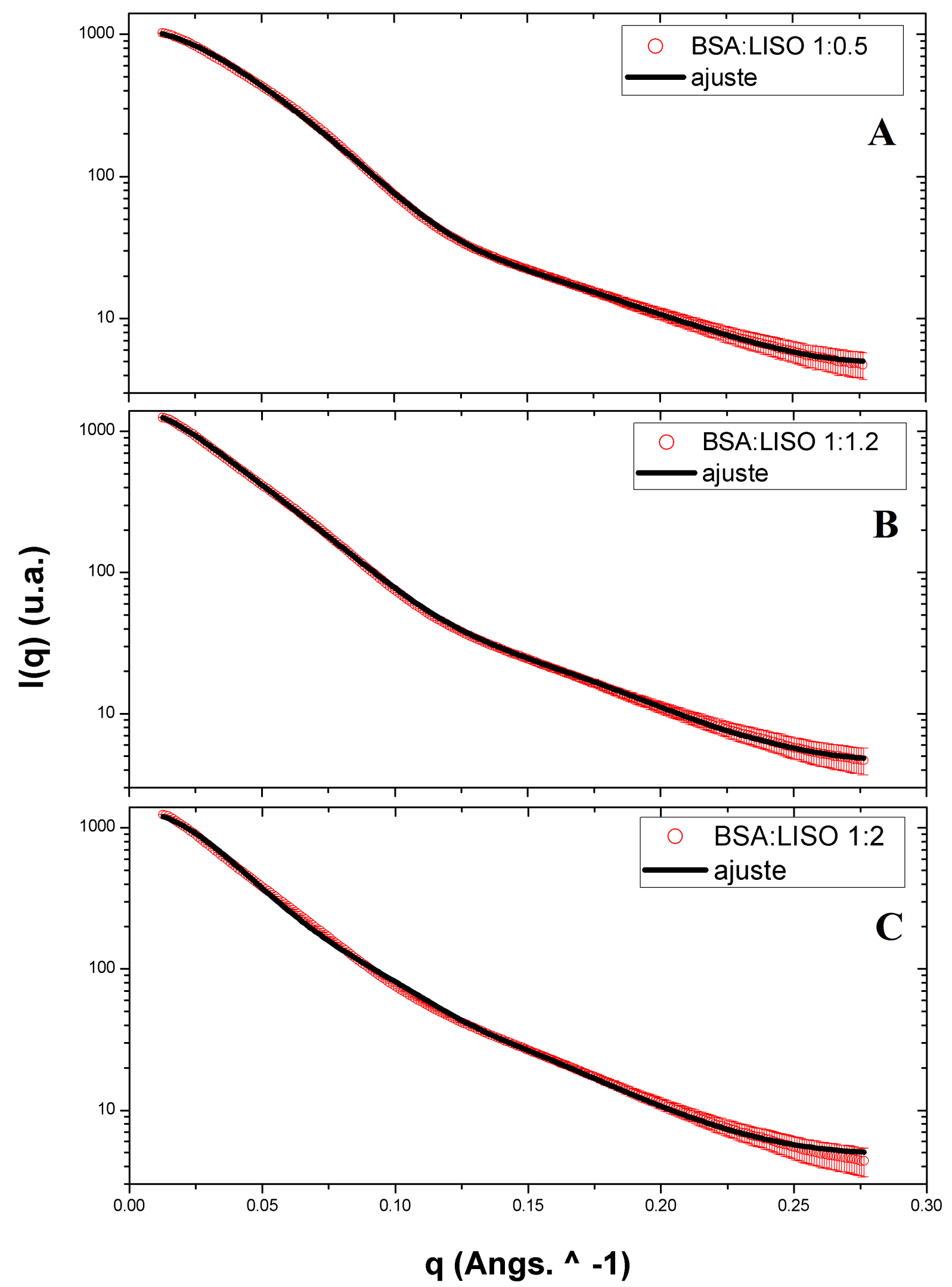

Figura 4.13: Melhores ajustes das curvas de SAXS para BSA e Lisozima a $\mathrm{T}=23^{\circ} \mathrm{C}, \mathrm{pH}$ 7.0 com (A) BSA:LISO 1:0,5; (B) BSA:LISO 1:1,2 e (C) BSA:LISO 1:2. 
Estudo da interação das proteínas globulares albumina de soro bovina (BSA) e 116

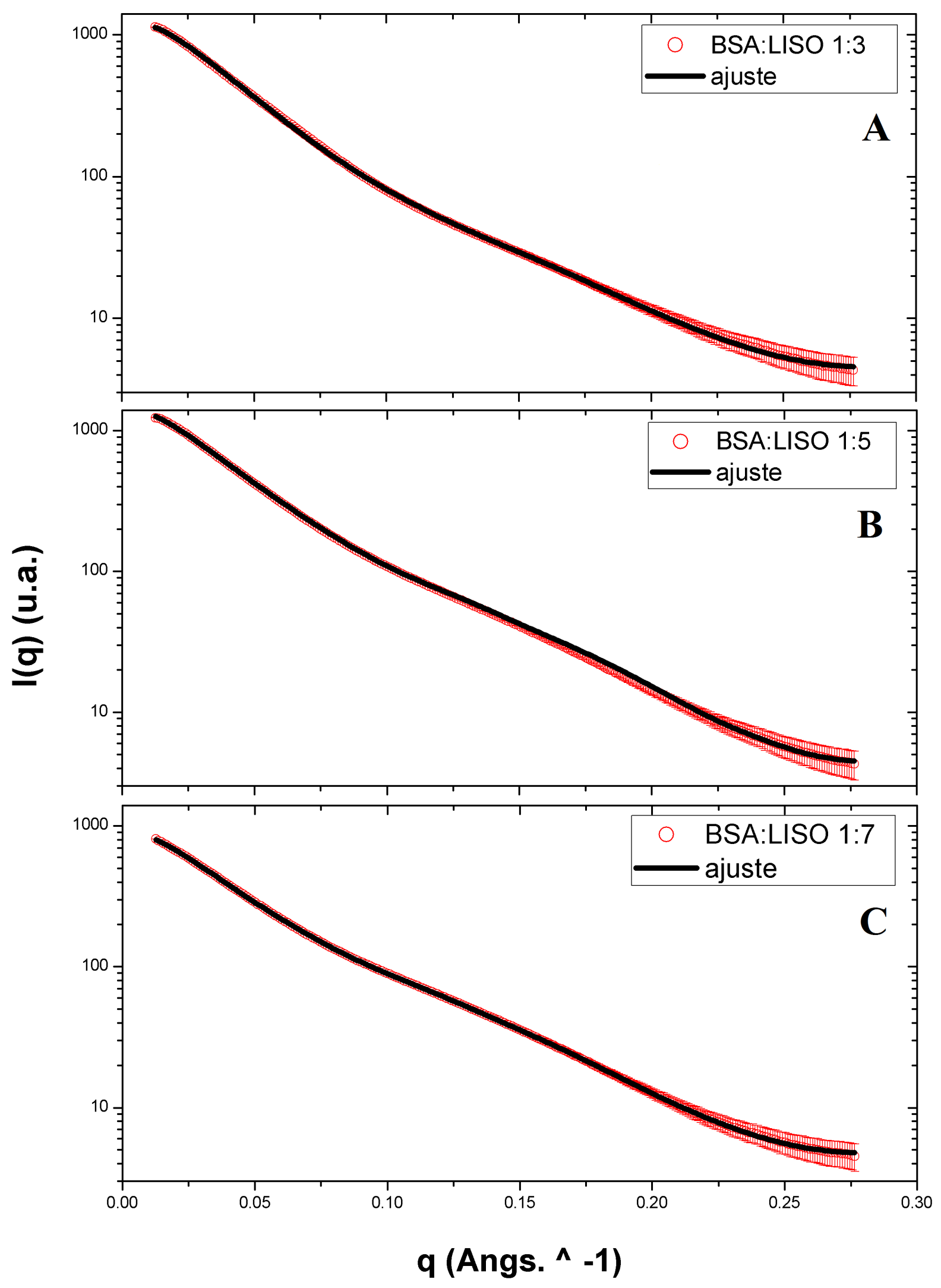

Figura 4.14: Melhores ajustes das curvas de SAXS para BSA e Lisozima a $\mathrm{T}=23^{\circ} \mathrm{C}, \mathrm{pH}$ 7.0 com (A) BSA:LISO 1:3; (B) BSA:LISO 1:5 e (C) BSA:LISO 1:7. 


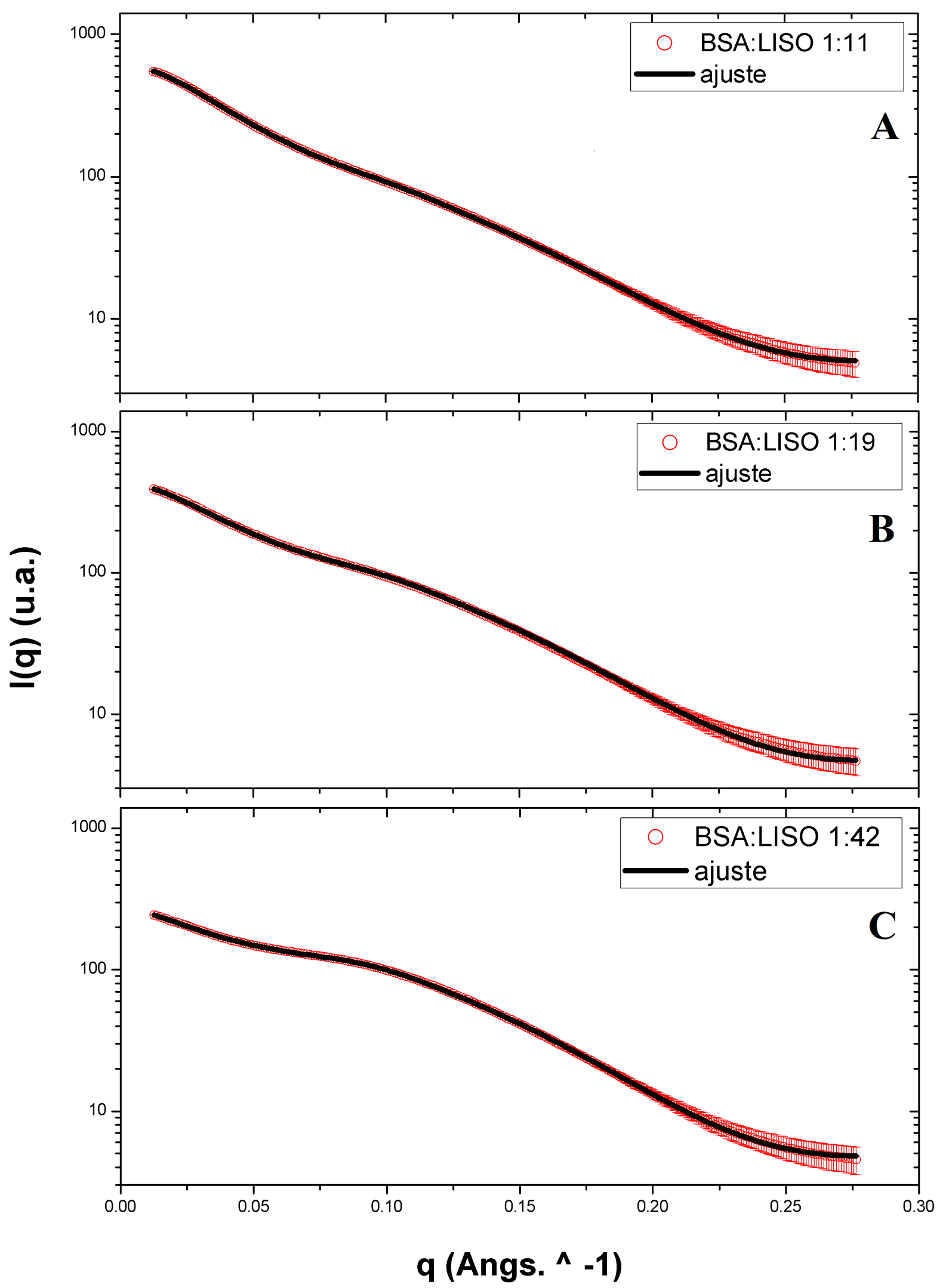

Figura 4.15: Melhores ajustes das curvas de SAXS para BSA e Lisozima a $\mathrm{T}=23^{\circ} \mathrm{C}, \mathrm{pH}$ 7.0 com (A) BSA:LISO 1:11; (B) BSA:LISO 1:19 e (C) BSA:LISO 1:42. 
Todas as funções de interferência equivalentes $S_{e q}$ estão no gráfico da Figura 4.16. Para uma melhor visualização das duas tendências observadas, na Figura 4.17. A estão as curvas com BSA:LISO 1:0,5, 1:1,2 e 1:2 e na Figura 4.17,B, as curvas de BSA:LISO 1:3 até 1:42. Conforme indicado pelas setas nas Figuras, na Figura 4.17.A verifica-se um aumento da amplitude de $S_{e q}$ na região até $q \leq 0,05 \AA^{-1}$.

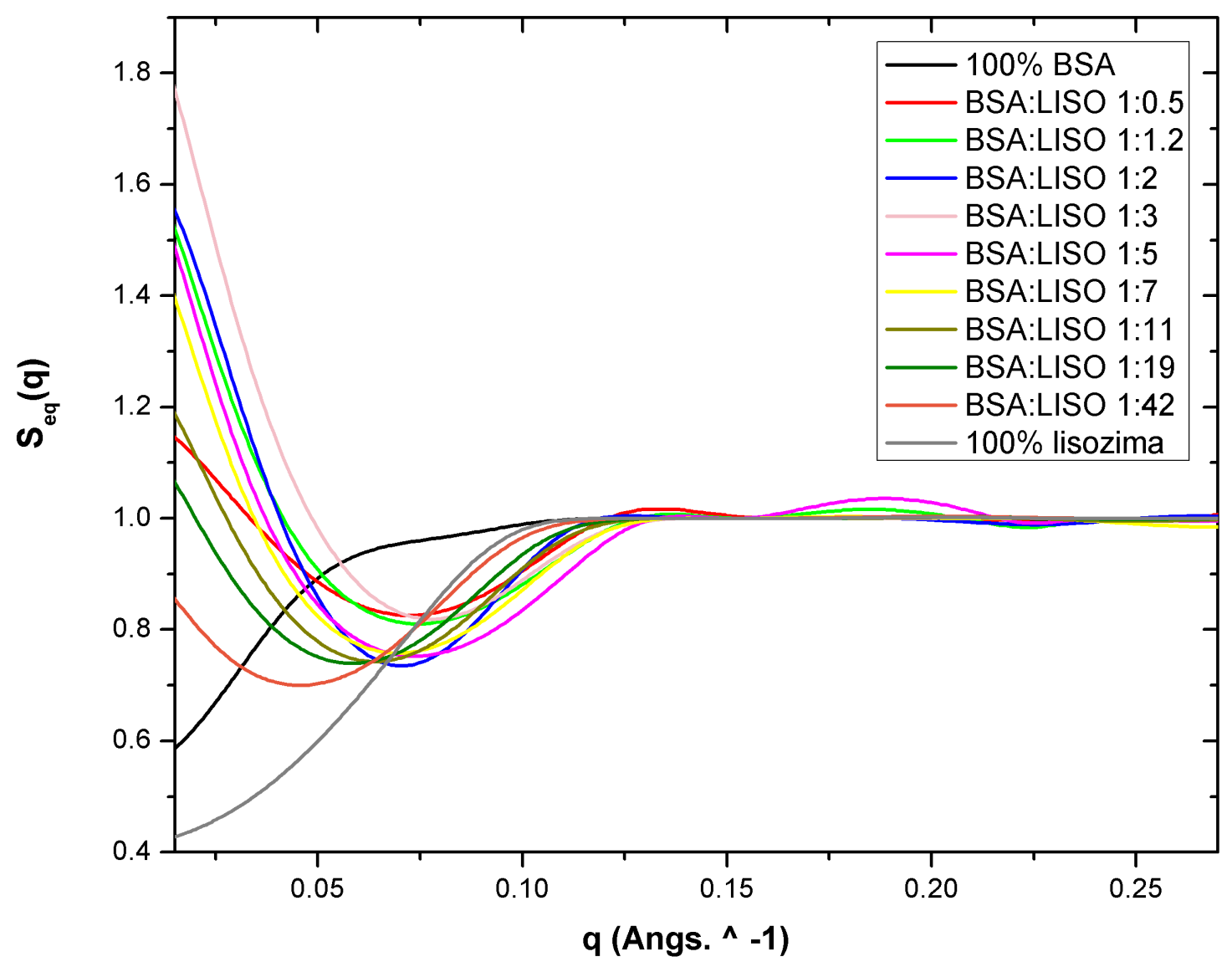

Figura 4.16: Funções de interferência $S_{e q}(q)$, para BSA:LISO 1:0,5 a BSA:LISO 1:42. 


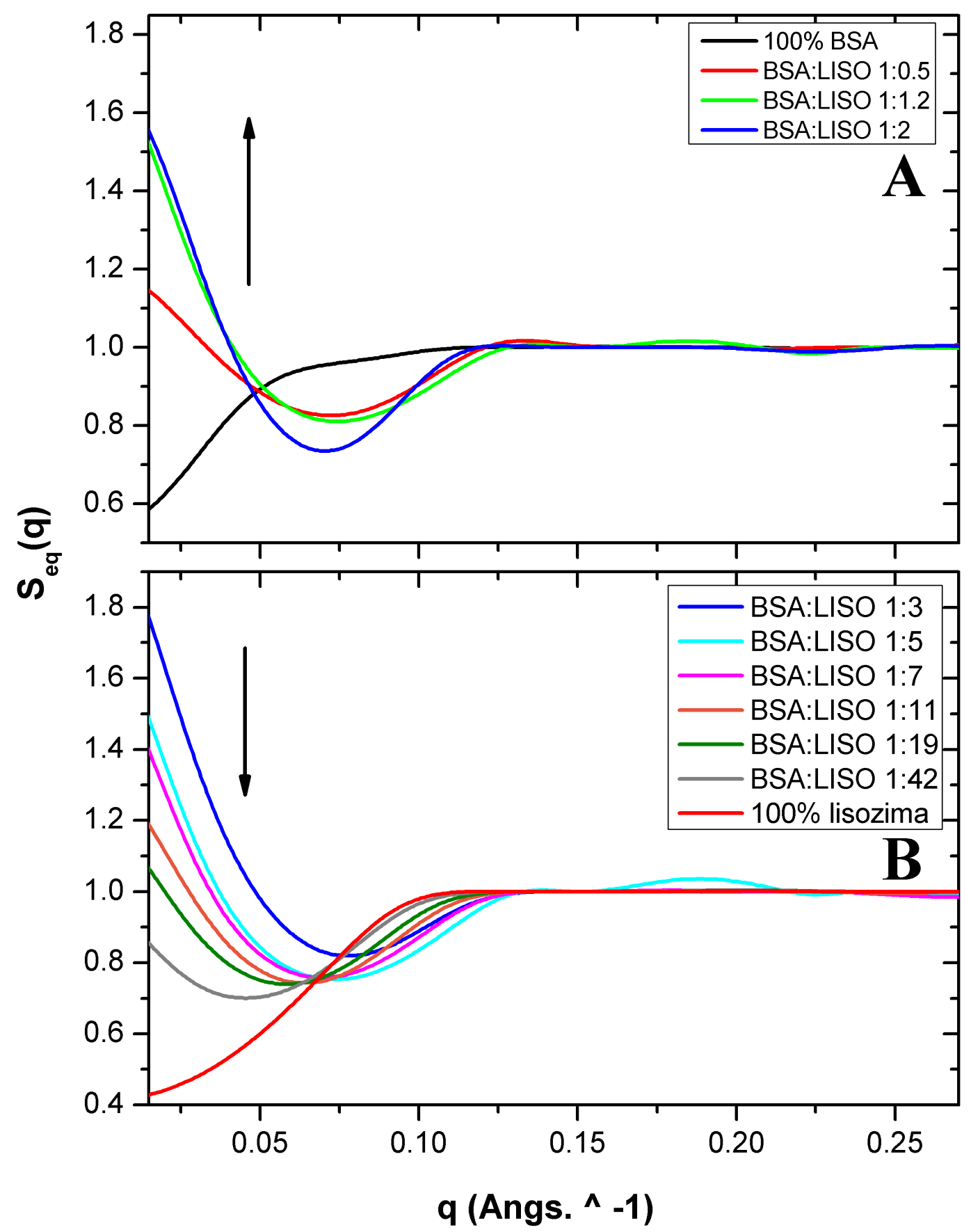

Figura 4.17: Funções de interferência $S_{e q}(q)$, para (A) BSA:LISO 1:0,5 a BSA:LISO 1:2 e (B) BSA:LISO 1:3 a BSA:LISO 1:42. 
Para ressaltar o caráter repulsivo e atrativo das interações entre BSA e lisozima dependentes da razão molar entre as proteínas, a Figura 4.18 apresenta os potenciais de interação, calculados conforme indicado na Secção 4.5, a partir dos parâmetros mostrados na Tabela 4.2. Novamente, assim como para as funções $S_{e q}(q)$, para que fosse possível melhor distinguir os comportamentos com o aumento da proporção de lisozima em solução, na Figura 4.19. A estão os potenciais para as amostras contendo BSA:LISO 1:0,5 a 1:2 e na Figura 4.19.B, os potenciais para BSA:LISO 1:3 a 1:42. Portanto, o potencial tende a valores mais negativos da proporção BSA:LISO de 1:0,5 a 1:2, evidenciando um aumento do efeito atrativo. A partir de BSA:LISO 1:3, verifica-se um decréscimo do caráter atrativo do potencial, em especial na região até $r \approx 60 \AA$.

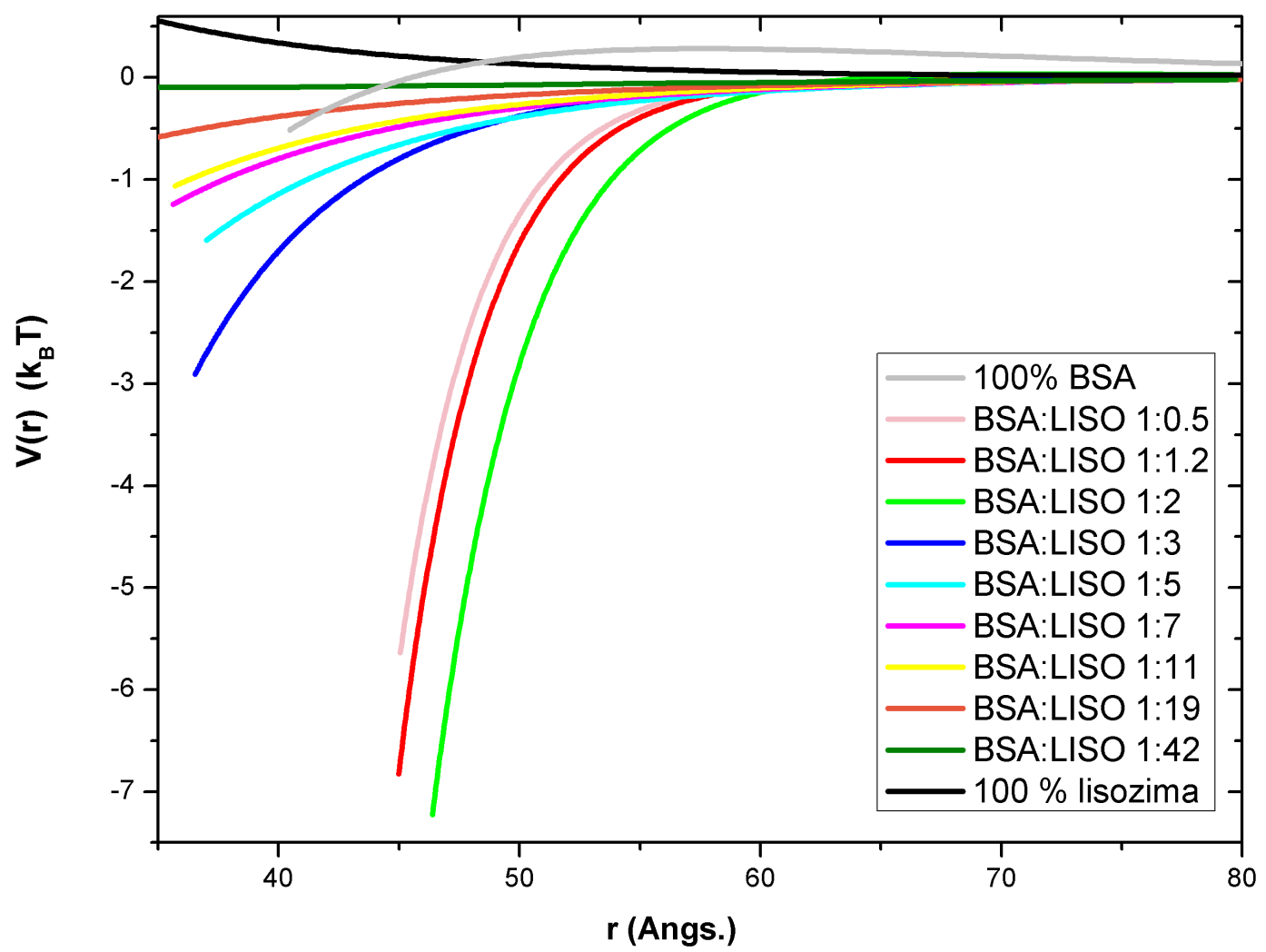

Figura 4.18: Potenciais para BSA:LISO 1:0,5 a BSA:LISO 1:42, 100\% BSA e 100\% lisozima. 


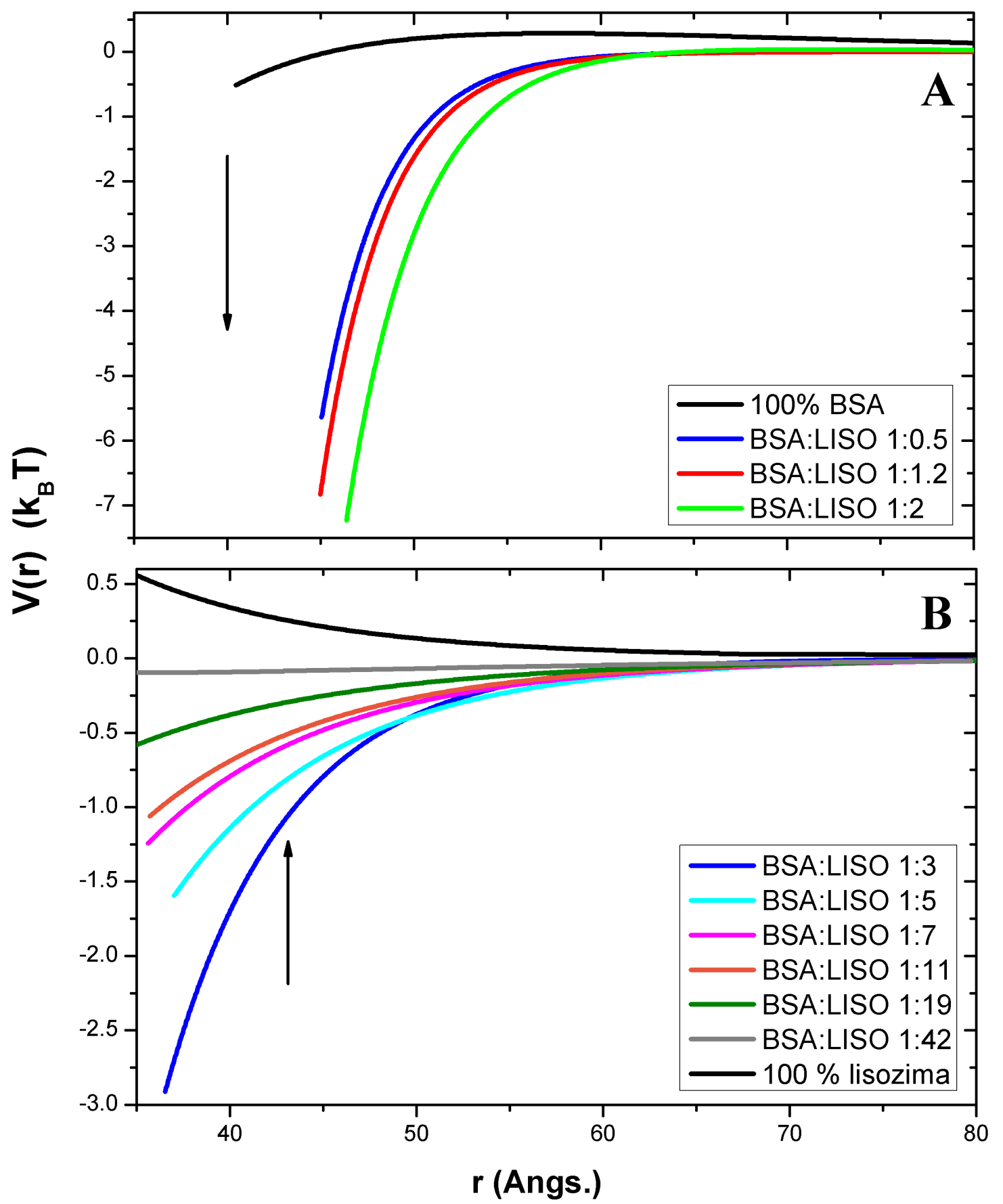

Figura 4.19: Potenciais para (A)100\% BSA, BSA:LISO 1:0,5 a BSA:LISO 1:2 e (B) BSA:LISO 1:3 a BSA:LISO 1:42 e 100\% lisozima. 


\subsection{Conclusão}

A utilização de uma função de interferência equivalente para o sistema, $S_{e q}(q)$, combinada aos fatores de forma calculados a partir das estruturas cristalográficas das proteínas, se mostrou adequada para a análise do sistema contendo BSA e lisozima em concentrações variáveis até a proporção de monômeros em solução BSA:LISO 1:42.

Os resultados permitem concluir que a concentração de $100 \mathrm{mg} / \mathrm{mL}$ de proteína total em solução, lisozima e BSA coexistem sem agregar (não foi observado floculação e/ou precipitação), através de um delicado balanço de forças atrativas e repulsivas no sistema. De maneira interessante, o diâmetro efetivo de interação tipo esfera dura diminui com a predominância de lisozima em solução. Por outro lado, na razão molar de BSA:LISO 1:2 a carga efetiva no sistema é pequena (menor que para soluções compostas apenas por BSA ou por lisozima, Tabela 4.2 e a profundidade do poço de potencial atinge seu valor máximo, refLetindo na maior amplitude "negativa"do potencial atrativo resultante entre as proteínas (Figura 4.19.A). Por sua vez, a partir de BSA:LISO 1:3 até BSA:LISO 1:42 o balanço entre potencial atrativo e repulsivo diminui o caráter atrativo do potencial resultante conforme ocorre o aumento da proporção de lisozima em solução. 


\section{Capítulo 5}

\section{Considerações Finais}

O objetivo desta tese consistiu estudar as interações proteína-proteína, proteína-membrana e proteína-agentes desnaturantes utilizando como ferramenta experimental a técnica de SAXS. Diversos sistemas foram estudados:

- No Capítulo 1, investigamos o processo de agregação do domínio GTPase da septina 6 (SEPT6G) e do complexo septina2G-septina6G (SEPT2G-SEPT6G) em função da temperatura, avaliando também a cinética temporal de aproximadamente 13 minutos de observação experimental. Verificamos que SEPT2G-SEPT6G forma, de fato, um heterodímero até $45^{\circ} \mathrm{C}$, mantendo sua estabilidade ao longo do tempo. Já homodímeros de SEPT2G e de SEPT6G coexistem em solução com oligômeros tipo cilindro e grandes agregados já a partir de $25^{\circ} \mathrm{C}$. Tais agregados evoluem com o tempo e a temperatura. Como perspectiva, estamos finalizando no momento um artigo científico em colaboração com a Profa. Ana Paula U. Araujo associando os dados de SAXS com os de dicroísmo circular e espectroscopia de fluorescência da sonda Tioflavina $\mathrm{T}$.

- No Capítulo 2, concluímos que não há diferenças estruturais entre lipossomos de DPPC e DPPC:DPPS (9:1) utilizados para mimetizar vesículas de matriz extracelular (MVs) [36]. A presença de $2 \mathrm{mM}$ de cálcio na dispersão dos lipossomos também não impacta nas propriedades estruturais dos mesmos. Por outro lado, nossos resultados experimentais de SAXS nos dão suporte para concluir que a anexina humana $\mathrm{V}$ (A5) interage com os lipossomos tanto de DPPC quanto de DPPC:DPPS (9:1), evidenciado por uma variação da densidade eletrônica da região polar da membrana modelo. Tal fato deve 
estar associado a formação de poros na membrana, corroborando com dados prévios da literatura [30], [32], [33], [35]. A presença da fosfatase alcalina tecido não-específico (TNAP), a uma concentração 10 vezes menor que a de A5, não altera o perfil de densidade eletrônica dos proteolipossomos de A5. Através da metodologia empregada nesta tese, não foi possível identificar qual o tipo e tamanho do poro formado na membrana. Como perspectiva, estamos trabalhando em simular curvas teóricas assumindo a formação de trímeros, tetrâmeros e hexâmeros de A5 nas membranas modelo, em colaboração com o Prof. Francesco Spinozzi (Università Politecnica delle Marche) e grupo do Prof. Pietro Ciancaglini (FFCLRP-USP).

- No Capítulo 3, estudamos a estabilidade térmica da proteína BSA com pH 7.0, sob ação de dois agentes desnaturantes, surfactante dodecil sulfato de sódio (SDS) e uréia, na conformação e agregação da proteína. Para as amostras sem uréia, a presença de até 30 mM de SDS não alterou a conformação da proteína, de maneira que foi observada a formação de micelas de SDS coexistindo com a proteína livre em solução. A curva de SAXS correspondente ao sistema composto por $50 \mathrm{mM}$ de SDS e BSA foi bem descrito pelo modelo de proteína parcialmente desenovelada, "colar de pérolas", com uma pequena parcela de BSA livre em solução. Nas amostras contendo BSA, uréia e SDS, o modelo de "colar de pérolas"também se mostrou satisfatório para ajustar as curvas experimentais em concentrações acima de $6 \mathrm{mM}$ de SDS. Adicionalmente, observou-se um aumento da agregação da proteína dependente da temperatura e da concentração de uréia e SDS, mas sem alteração no desenovelamento da proteína. Além disso, os resultados mostraram que a termoestabilidade da BSA parcialmente desenovelada pela ação da uréia diminui com a adição de pequenas concentrações de SDS na presença de uréia.

- No Capítulo 4, investigamos o potencial efetivo resultante da interação entre duas proteínas distintas, BSA e lisozima a concentração total de $100 \mathrm{mg} / \mathrm{mL}$ em solução, variando a razão molar BSA:LISO até 1:42, pH 7.0. Utilizamos uma análise simplificada de curvas de SAXS considerando um potencial efetivo de interação entre BSA-BSA, lisozima-lisozima e lisozima-BSA, que consiste da soma de um potencial de esfera dura, um poço de potencial atrativo tipo Lenard-Jonnes e um potencial eletrostático de Coulomb blindado. Considerando razões molares de até BSA:LISO 1:2, a carga efetiva no sistema é praticamente nula e a profundidade do poço de potencial atinge seu valor 
máximo (em módulo). Entretanto tal domínio de força atrativa entre as proteínas não leva à separação de fase (floculação e precipitação). A partir de BSA:LISO 1:3 até BSA:LISO 1:42 a carga efetiva aumenta e o potencial resultante tem caráter repulsivo. Como perspectiva, estudaremos sistemas similares, mas alterando a viscosidade do solvente pela adição de glicerol, visando dar mais um passo na mimetização de sistemas densos. 



\section{Referências Bibliográficas}

[1] L. R. Barbosa, F. Spinozzi, P. Mariani, and R. Itri, Proteins in Solution and Interfaces: Methods and Applications in Biotechnology and Materials Science. John Wiley and Sons, Inc, 2013.

[2] M. Sirajuddin, M. Farkasovsky, F. Hauer, D. Kuhlmann, I. G. Macara, M. Weyand, H. Stark, and A. Wittinghofer, "Structural insight into filament formation by mammalian septins," Nature 449 (2007) 311-315.

[3] N. Beise and W. Trimble, "Septins at a glance," Journal of Cell Science 124 (2011) 4141-4146.

[4] F. Pan, R. L. Malmberg, and M. Momany, "Analysis of septins across kingdoms reveals orthology and new motifs," BMC Evolutionary Biology 7:103 (2007).

[5] B. Kartmann and D. Roth, "Novel roles for mammalian septins: from vesicle trafficking to oncogenesis," Journal of Cell Science 114 n. 5 (2001) 839-844.

[6] E. T. Spiliotis, "Regulation of microtubule organization and functions by septin GTPases," Cytoskeleton 67 (2010) 339-345.

[7] S. K. Ford and J. R. Pringle, "Cellular morphogenesis in the saccharomyces cerevisiae cell cycle: Localization of the CDC11 gene product and the timing of events at the budding site," Developmental Genetics 12(4) (1991) 281-292.

[8] M. E. Pablo-Hernando, Y. Arnaiz-Pita, H. Tachikawa, F. del Rey, A. M. Neiman, and C. R. V. de Aldana, "Septins localize to microtubules during nutritional limitation in saccharomyces cerevisiae," BMC Cell Biology 9 (2008) 55.

[9] N. F. Valadares, H. dMuniz Pereira, A. P. U. de Araujo, and R. C. Garratt, "Septin structure and filament assembly," Biophysical Reviews 9(5) (2017) 481-500.

[10] J. C. P. Damalio, W. Garcia, J. N. A. Macedo, I. de Almeida Marques, J. M. Andreu, R. Giraldo, R. C. Garratt, and A. P. U. Araujo, "Self assembly of human septin 2 into amyloid filaments," Biochimie 11 (2011) 1-9. 
[11] J. C. P. Damalio, Estudos bioquímicos, funcionais e estruturais da septina humana SEPT2: fatores que determinam a formação de agregados. Tese de doutorado, IFSC, 2011.

[12] E. M. Sales, "Estudos estruturais do processo de agregação entre proteínas amilóides em solução," Dissertação de Mestrado, IFUSP, 2012.

[13] C. S. Martins, "Análise das interfaces de interacao septina-septina," Dissertação de Mestrado, Instituto de Física de São Carlos da Universidade de São Paulo, 2017.

[14] E. Mylonas and D. I. Svergun, "Accuracy of molecular mass determination of proteins in solution by small-angle X-ray scattering," Journal of Applied Crystallography 40 (2007) s245-s249.

[15] O. Glatter and O. Kratky, Small Angle X-ray Scattering. Academic Press, 1982.

[16] M. G. Ortore, F. Spinozzi, P. Mariani, A. Paciaroni, L. R. S. Barbosa, H. Amenitsch, M. Steinhart, J. Ollivier, and D. Russo, "Combining structure and dynamics: non denaturating high-pressure effect on lysozyme in solution," Journal of Royal Society Interface 6 (2009) S619-S634.

[17] F. Spinozzi, C. Ferrero, M. G. Ortore, A. D. M. Antolinos, and P. Mariani, "Genfit: software for the analysis of small-angle x-ray and neutron scattering data of macromolecules in solution," J. Appl. Cryst. 47 (2014) 1132-1139.

[18] A. Guinier and G. Fournet, Small Angle Scattering of X-Rays. Wiley, New York, 1955.

[19] J. Pedersen, "Analysis of small-angle scattering data from colloids and polymer solutions: modeling and least-squares fitting," Advances in Colloid and Interface Science 70 (1997) 171-210.

[20] M. G. Ortore, F. Spinozzi, S. Vilasi, I. Sirangelo, G. Irace, A. Shukla, T. Narayanan, R. Sinibaldi, and P. Mariani, "Time-resolved small-angle X-ray scattering study of the early stage of amyloid formation of an apomyoglobin mutant," Physical Review E $\mathbf{8 4}$ (2011) 061904-1-10. 
[21] M. Balcerzak, E. Hamade, S. P. L. Zhang, G. Azzar, J. Radisson,

J. Bandorowicz-Pikula, and R. Buchet, "The roles of annexins and alkaline phosphatase in mineralization process," Acta Biochim. Pol. 50 (2003) 1019-1038.

[22] T. Kirsch, "Biomineralization - an active or passive process?," Connective Tissue Research 6 (2012) 438-445.

[23] R. Hauptmann, I. Maurer-Fogy, E. Krystek, G. Bodo, H. Andree, and C. Reutelingsperger, "Vascular anticoagulant beta (vac-beta: a novel human ca2+ phospholipid binding protein that inhibits coagulation and phospholipase a2 activity," Eur. J. Biochem. 185 (1989) 63-71.

[24] R. Wuthier and G. Lipscomb, "Matrix vesicles: structure, composition, formation and function in calcification," Front. Biosci. 16 (2011) 2812-2902.

[25] H. O. van Genderen, H. Kenis, L. Hofstra, J. Narula, and C. P. Reutelingsperger, "Extracellular annexin a5: Functions of phosphatidylserine-binding and two-dimensional crystallization," Biochimica et Biophysica Acta 1783 (2008) 953-963.

[26] R. Huber, R. Berendes, A. B. M. Schneider, A. Karshikov, and H. Luecke, "Crystal and molecular structure of human annexin $\mathrm{v}$ after refinement: Implications for structure, membrane binding and ion channel formation of the annexin family of proteins," J. Mol. Biol. 223 (1992) 683-704.

[27] A. Brisson, G. Mosser, and R. Huber, "Structure of soluble and membrane-bound human annexin v," J. Mol. Biol. 220 (1991) 199-203.

[28] A. S. Rose, A. R. Bradley, Y. Valasatava, J. M. Duarte, A. Prlic, and P. W. Rose, "Web-based molecular graphics for large complexes," ACM Proceedings of the 21st International Conference on Web3D Technology (2016) 185-186.

[29] A. S. Rose and P. W. Hildebrand, "Ngl viewer: a web application for molecular visualization," Nucl Acids Res 43 (2015) W576-W579.

[30] F. Oling, J. S. de Oliveira Santos, N. Govorukhina, C. Mazeres-Dubut, W. Bergsma-Schutter, G. Oostergetel, W. K. O. Lambert, A. Lewit-Bentley, and A. Brisson, "Structure of membrane-bound annexin a5 trimers: A hybrid cryo-em x-ray crystallography study," J. Mol. Biol. 304 (2000) 561-573. 
[31] R. P. Richter, J. L. K. Him, B. Tessier, C. Tessier, and A. R. Brisson, "On the kinetics of adsorption and two-dimensional self-assembly of annexin a5 on supported lipid bilayers," Biophysical Journal 89 (2005) 3372-3385.

[32] T. Kirsch, H. D. Nah, D. R. Demuth, G. Harrison, E. E. Golub, S. L. Adams, and M. Pacifici, "Annexin v-mediated calcium flux across membranes is dependent on the lipid composition: Implications for cartilage mineralization," Biochemistry 36 (1997) 3359-3367.

[33] H. Luecke, B. T. Chang, W. S. Mailliard, D. D. Schlaepfer, and H. T. Haigler, "Crystal structure of the annexin xii hexamer and implications for bilayer insertion," Nature 378 (1995) 512-515.

[34] M. Giocondi, F. Besson, P. Dosset, P. Milhiet, and C. L. Grimellec, "Remodeling of ordered membrane domains by gpi-anchored intestinal alkaline phosphatase," Langmuir 23 (2007) 9358-9364.

[35] M. Bolean, A. Simao, B. Favarin, J. Millan, and P. Ciancaglini, "Thermodynamic properties and characterization of proteoliposomes rich in microdomains carrying alkaline phosphatase," Archives of Biochemistry and Biophysics 158 (2011) 111-118.

[36] M. Bolean, A. Simao, T. Kiffer-Moreira, M. F. Hoylaerts, J. Millan, R. Itri, and P. Ciancaglini, "Proteoliposomes with the ability to transport ca2 + into the vesicles and hydrolyze phosphosubstrates on their surface," Archives of Biochemistry and Biophysics 584 (2015) 79-89.

[37] F. Spinozzi, C. Ferrero, M. G. Ortore, A. D. M. Antolinos, and P. Mariani, "Genfit: software for the analysis of small-angle x-ray and neutron scattering data of macromolecules in solution," J. Appl. Cryst. Supplementary Material (2014) 1-21.

[38] T. Fruhwirth, G. Fritz, N. Freiberger, and O. Glatter, "Structure and order in lamellar phases determined by small-angle scattering," J. Appl. Cryst. 37 (2004) 703-710.

[39] M. M. Domingues, M. L. Bianconi, L. R. Barbosa, P. S. Santiago, M. Tabak, M. A. Castanho, R. Itri, and N. C. Santos, "rbpi 21 interacts with negative membranes endothermically promoting the formation of rigid multilamellar structures," Biochimica et Biophysica Acta 1828 (2013) 2419-2427. 
[40] I. O. L. Bacellar, C. Pavani, E. M. Sales, R. Itri, M. Wainwright, and M. S. Baptista, "Membrane damage efficiency of phenothiazinium photosensitizers," Photochemistry and Photobiology 90 (2014) 801-813.

[41] F. Spinozzi, L. Paccamiccio, P. Mariani, , and L. Q. Amaral, "Melting regime of the anionic phospholipid dmpg: New lamellar phase and porous bilayer model," Langmuir 26(9) (2010) 6484-6493.

[42] "https://avantilipids.com/product/850355. acesso em 28/01/2018."

[43] "https://avantilipids.com/product/840037. acesso em 28/01/2018."

[44] P. Ciancaglini, A. Simao, M. Bolean, J. Millan, C. Rigos, J. Yoneda, M. Colhone, and R. Stabeli, "Proteoliposomes in nanobiotechnology," Biophys. Rev. 4 (2012) 67-81.

[45] M. Bolean, A. Simao, B. Favarin, J. Millan, and P. Ciancaglini, "The effect of cholesterol on the reconstitution of alkaline phosphatase into liposomes," Biophysical Chemistry 152 (2010) 74-79.

[46] K. A. Riske, L. Q. Amaral, H.-G. Dobereiner, and M. T. Lamy, "Mesoscopic structure in the chain-melting regime of anionic phospholipid vesicles: Dmpg," Biophysical Journal 86 (2004) 3722-3733.

[47] T. Peters, All about Albumins: Biochemistry, Genetics and Medical Applications. Academic Press, 1996.

[48] D. Carter, B. Chang, J. Ho, K. Keeling, and Z. Krishnasami, "Preliminary crystallographic studies of four crystal forms of serum albumin," Eur. J. Biochem. 226 (1994) 1049-1052.

[49] J. Brown and P. Shockley, Lipid-Protein Interactions. Wiley, 1982.

[50] X. M. He and D. Carter, "Atomic structure and chemistry of human serum albumin," Nature 358 (1992) 209-215.

[51] S. Curry, H. Mandelkow, P. Brick, and N. Franks, "Crystal structure of human serum albumin complexed with fatty acid reveals an asymmetric distribution of binding sites," Nat. Struct. Biol. 5 (1998) 827-835. 
[52] e. Structures of bovine and leporine serum albumin, "Anna bujacz," Acta Cryst. D68 (2012) 1278-1289.

[53] C. Tanford, The Hydrophobic Effect: Formation of Micelles and Biological Membranes. Wiley, 1973.

[54] "https://www.wikidoc.org/images/a/ae/sds-2d-skeletal.png. acesso em 03/03/2018."

[55] S. F. Santos, D. Zanette, H. Fischer, and R. Itri, "A systematic study of bovine serum albuimin (bsa) and sodium dodecyl sulfate (sds) interactions by surface tension and small angle x-ray scattering," Colloid and Interface Science 262 (2003) 400-408.

[56] J. M. K. amd Atiyatul Qadeer, S. K. Chaturvedi, E. Ahmad, S. A. A. Rehman, S. Gourinath, and R. H. Khan, "Sds can be utilized as an amyloid inducer: A case study on diverse proteins," PLoS ONE 7 (2012) e29694 1-8.

[57] V. A. Borzova, K. A. Markossian, N. A. Chebotareva, S. Y. Kleymenov, N. B. Poliansky, K. O. Muranov, V. A. Stein-Margolina, V. V. Shubin, D. I. Markov, and B. I. Kurganov, "Kinetics of thermal denaturation and aggregation of bovine serum albumin," PLoS ONE (2016) 1-29.

[58] "https://www.sigmaaldrich.com/catalog/product/aldrich/208884. acesso em 03/05/2018."

[59] R. Itri, P. S. Santiago, L. R. Barbosa, and M. Tabak, Spectroscopic and structural studies of interaction of biomolecules with surfactant aggregates. Transworld Research Network, 2009.

[60] J. Teixeira, "Small-angle scattering by fractal systems," J. Appl. Cryst. 21 (1988) $781-785$.

[61] A. M. Percebom, L. R. S. Barbosa, R. Itri, and W. Loh, "How does the ethoxylated grafting of polyelectrolytes affect the self-assembly of polyanion-cationic surfactant complex salts?," Langmuir 30 (2014) 11493-11503.

[62] L. R. S. Barbosa, M. G. Ortore, F. Spinozzi, P. Mariani, S. Bernstorff, and R. Itri, "The importance of protein-protein interactions on the ph-induced conformational 
changes of bovine serum albumin: A small-angle x-ray scattering study," Biophysical Journal 98 (2010) 147-157.

[63] E. L. Gelamo, R. Itri, A. Alonso, J. V. da Silva, and M. Tabak, "Small-angle x-ray scattering and electron paramagnetic resonance study of the interaction of bovine serum albumin with ionic surfactants," Journal of Colloid and Interface Science $\mathbf{2 7 7}$ (2004) 471-482.

[64] D. P. Goldenberg and B. Argyle, "Self crowding of globular proteins studied by small-angle x-ray scattering," Biophysical Journal 106 (2014) 895-904.

[65] J. Hong and L. M. Gierasch, "Macromolecular crowding remodels the energy landscape of a protein by favoring a more compact unfolded state," J. Am. Chem. Soc. 132 (2010) 10445-10452.

[66] A. Rajapaksha, C. B. Stanley, and B. A. Todd, "Effects of macromolecular crowding on the structure of a protein complex: A small-angle scattering study of superoxide dismutase," Biophysical Journal 108 (2015) 967-974.

[67] D. I. Svergun and L. A. Feigin, Structure analysis by Small-angle X-ray and Neutron Scattering. Plenum Press, NY, 1987.

[68] D. I. Svergun and M. H. J. Koch, "Small-angle scattering studies of biological macromolecules in solution," Reports on Progress in Physics 66 (2003) 1735-1782.

[69] H. D. T. Martens and D. I. Svergun, "Structural characterization of proteins and complexes using small-angle X-ray solution scattering," Journal of Structural Biology 172 (2010) 128-141.

[70] J. Brunner-Popela and O. Glatter, "Small-angle scattering of interacting particles. i. basic principles of a global evaluation technique," J. Appl. Cryst. 30 (1997) 431-442.

[71] J. Narayanan and X. Y. Liu, "Protein interactions in undersaturated and supersaturated solutions: A study using light and x-ray scattering," Biophysical Journal 84 (2003) 523-532.

[72] P. Hansen and I. R. McDonald, Theory of Simple Liquids. Academic Press, London, UK, 1976. 
[73] J. Narayanan and X. Y. Liu, "Protein interactions in undersaturated and supersaturated solutions: a study using light and x-ray scattering," Biophysical Journal 84 (2003) 523-532. 


\section{Apêndice A}

\section{Análise das amostas contendo BSA e li- sozima utilizando o modelo de elipsoide}

\section{A.1 Combinação dos modelos de agregados elipsoides com as estruturas cristalográficas da BSA e lisozima}

A intensidade de espalhamento de raios-X a baixos ângulos pode ser escrita como:

$$
I(q)=k\left(n_{B S A} P_{B S A}+n_{\text {liso }} P_{\text {liso }}+n_{\text {elipsoide }} P_{\text {elipsoide }}\right)
$$

onde $k$ é o fator de escala, $n_{B S A}, n_{\text {liso }}$ e $n_{\text {elipsoide }}$ são as densidades numéricas de partículas de BSA e lisozima em solução e na forma de elipsoide, respectivamente. O fator de forma $P_{B S A}$ e $P_{\text {liso }}$ são calculadas a partir das estruturas cristalográficas das proteínas. Por sua vez, o fator de forma do elipsoide é o mesmo que descrito na Seção 3.5.1, representando neste caso, um agregado composto por monômeros de BSA e lisozima.

Reescrevendo o número de partículas na forma de elipsoide em função do número de partículas conhecido de cada proteína:

$$
n_{\text {elipsoide }}=\left(n_{\mathrm{BSA} \text { inicial }}+n_{\text {liso inicial }}\right)-n_{B S A}-n_{\text {liso }}
$$

O volume do elipsoide deve ser a soma do volume das partículas que o compõem. Assim: 


$$
\begin{gathered}
V_{\text {elipsoide }}=\left(n_{\mathrm{BSA} \text { inicial }}-n_{B S A}\right) V_{B S A}+\left(n_{\text {liso inicial }}-n_{\text {liso }}\right) V_{\text {liso }} \\
\frac{4}{3} \pi \nu R^{3}=\left(n_{\mathrm{BSA} \text { inicial }}-n_{\mathrm{BSA}}\right) V_{\mathrm{BSA}}+\left(n_{\text {liso inicial }}-n_{\text {liso }}\right) V_{\text {liso }} \\
\nu=\frac{3}{4 \pi} \frac{1}{R^{3}}\left[\left(n_{\mathrm{BSA} \text { inicial }}-n_{\mathrm{BSA}}\right) V_{\mathrm{BSA}}+\left(n_{\text {liso inicial }}-n_{\text {liso }}\right) V_{\text {liso }}\right]
\end{gathered}
$$

Conforme foi mostrado na Seção 4.8 , a função $p(r)$ para solução contendo apenas lisozima possui um vale negativo, indicando um potencial de interação repulsivo entre lisozimas. Tais resultados da $p(r)$, raio de giro e $I(0)$, indicaram uma possível análise utilizando uma abordagem que consideraria a formação de agregados elipsoidais ou cilíndricos, devido a atração entre as proteínas, coexistindo com a BSA e lisozima livres em solução. Apesar dos ajustes obtidos serem satisfatórios mostrados neste apêndice o agregado elipsoide se mantém com as mesmas dimensões com o aumento da porcentagem da lisozima, aumentando apenas a contribuição para a intensidade do espalhamento. De acordo com os resultados de $p(r)$, seria esperado que o agregado aumentasse de tamanho com o aumento da concentração de lisozima, até a razão BSA:LISO 1:5. A partir da razão BSA:LISO 1:7, os agregados diminuiriam de tamanho (Figuras 4.5, 4.6 e 4.8.B). Desta forma, pela incongruência nas análises de $p(r)$, raio de giro e $\mathrm{I}(0)$, descartou-se esta abordagem apesar dos bons ajustes das curvas experimentais. Além da abordagem utilizando o modelo de elipsoide, também foram feitas tentativas de ajustes apenas com as estruturas cristalográficas das proteínas e outra, ainda, com o modelo de agregado cilíndrico, que também não foram adequadas para descrever as curvas experimentais. 
A.1. Combinação dos modelos de agregados elipsoides com as estruturas cristalográficas da BSA e lisozima

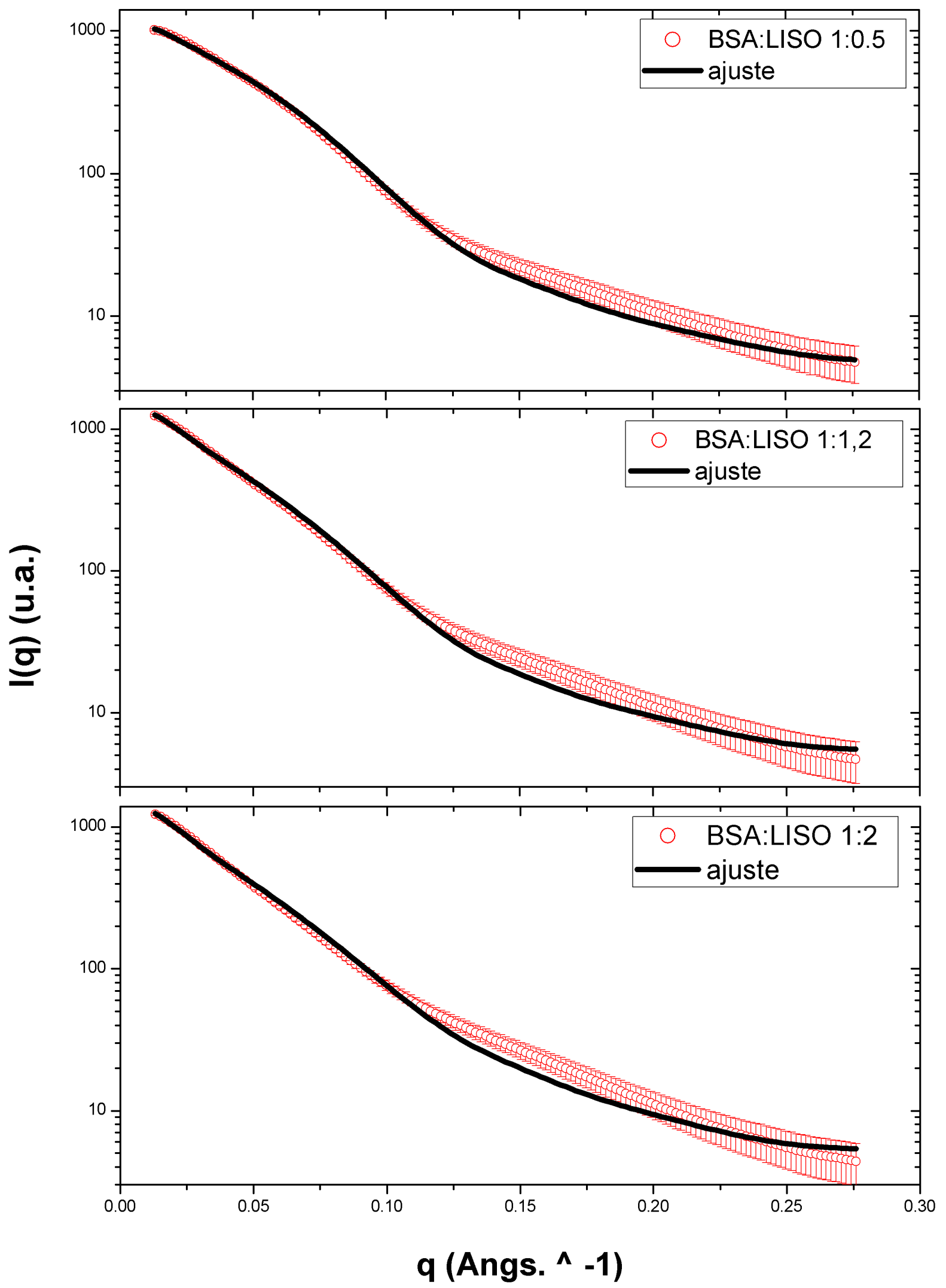

Figura A.1: Melhores ajustes das curvas de SAXS para BSA e Lisozima a $\mathrm{T}=23^{\circ} \mathrm{C}$, $\mathrm{pH} 7.0$ com (A) BSA:LISO 1:0,5; (B) BSA:LISO 1:1,2 e (C) BSA:LISO 1:2. 
1\$8álise das amostas contendo BSA e lisozima utilizando o modelo de elipsoide

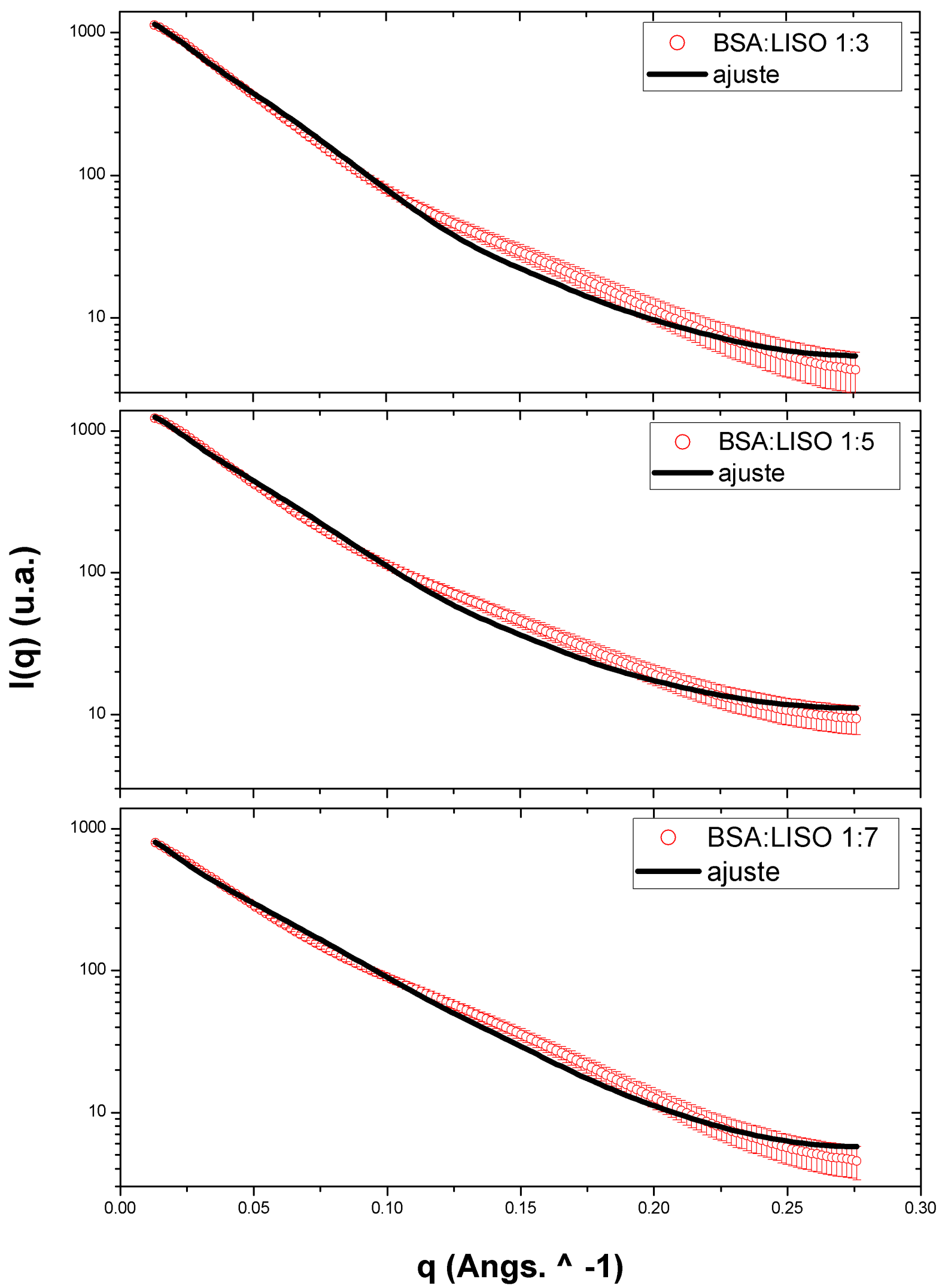

Figura A.2: $\quad$ Melhores ajustes das curvas de SAXS para BSA e Lisozima a $\mathrm{T}=23^{\circ} \mathrm{C}$, $\mathrm{pH} 7.0$ com (A) BSA:LISO 1:3; (B) BSA:LISO 1:5 e (C) BSA:LISO 1:7. 
A.1. Combinação dos modelos de agregados elipsoides com as estruturas cristalográficas da BSA e lisozima

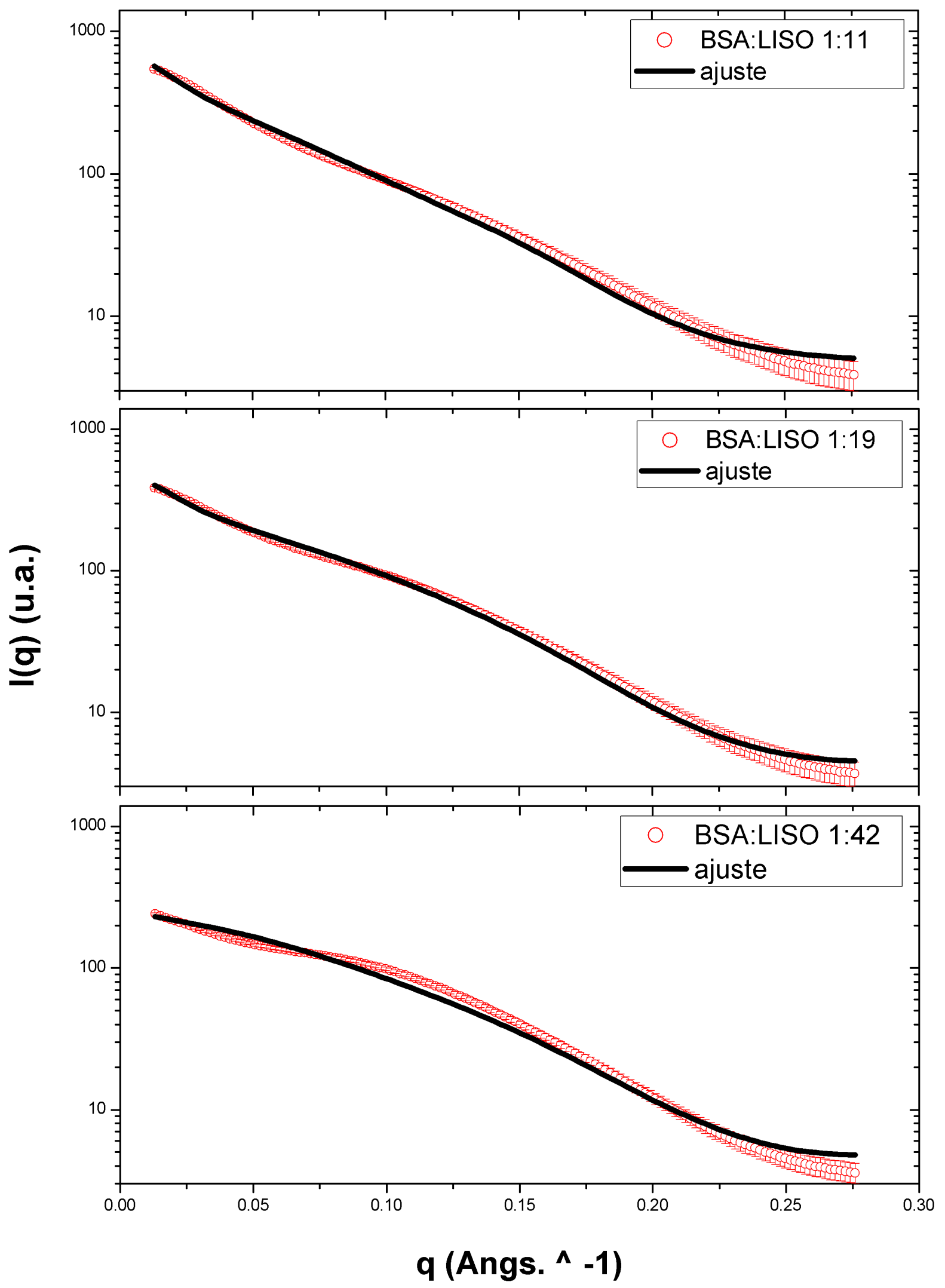

Figura A.3: Melhores ajustes das curvas de SAXS para BSA e Lisozima a $\mathrm{T}=23^{\circ} \mathrm{C}$, $\mathrm{pH} 7.0$ com (A) BSA:LISO 1:11; (B) BSA:LISO 1:19 e (C) BSA:LISO 1:42. 



\section{Anexo I}

\section{Publicações}

Neste Anexo encontram-se os trabalhos publicados no período do doutorado.

[1] Isabel O. L. Bacellar, Christiane Pavani, Elisa M. Sales, Rosangela Itri, Mark Wainwright, Mauricio S. Baptista, "Membrane Damage Efficiency of Phenothiazinium Photosensitizers", Photochemistry and Photobiology 90 (2014) 801-813.

[2] Cesar L Avila, Clarisa M Torres-Bugeau, Leandro RS Barbosa, Elisa Morandé Sales, Ouidir Ouidja, Sergio B Socias, Rita Raisman-Vozari, Dulce Papy-Garcia, Rosangela Itri, Rosana Chehin, "Structural characterization of heparin-induced GAPDH protofibrils preventing $\alpha$-synuclein oligomeric species toxicity", The Journal of Biological Chemistry 289 (2014) 13838-13850.

[3] Rosangela Itri, Elisa Morandé Sales, Leandro RS Barbosa, "Espalhamento de raios$\mathrm{X}$ a baixos ângulos (SAXS) aplicado ao estudo de proteínas não interagentes em solução"Estrategias y Avances en el Estudio de Toxinas de Interés para la Biomedicina, p. 169-189. Benemérita Universidad Autonoma de Puebla, 2015. 


\title{
Membrane Damage Efficiency of Phenothiazinium Photosensitizers
}

\author{
Isabel O. L. Bacellar ${ }^{1}$, Christiane Pavani ${ }^{1}$, Elisa M. Sales ${ }^{2,3}$, Rosangela Itri $^{2}$, Mark Wainwright ${ }^{4}$ and \\ Mauricio S. Baptista* ${ }^{* 1}$ \\ ${ }^{1}$ Departamento de Bioquímica, Instituto de Química, Universidade de São Paulo, São Paulo, Brasil \\ ${ }^{2}$ Departamento de Física Aplicada, Instituto de Física, Universidade de São Paulo, São Paulo, Brasil \\ ${ }^{3}$ Instituto de Pesquisas Tecnológicas do Estado de São Paulo, São Paulo, Brasil \\ ${ }^{4}$ School of Pharmacy and Biomolecular Sciences, Liverpool John Moores University, Liverpool, UK \\ Received 26 September 2013, accepted 21 February 2014, DOI: 10.1111/php.12264
}

\begin{abstract}
Structure-activity relationships have been widely reported for porphyrin and phthalocyanine photosensitizers, but not for phenothiazinium derivatives. Here, four phenothiazinium salts (methylene blue, toluidine blue O, 1,9-dimethyl methylene blue and the pentacyclic derivative DO15) were used to investigate how the ability to damage membranes is affected by membrane/solution partition, photophysical properties and tendency to aggregation of the photosensitizer. These two latter aspects were studied both in isotropic solutions and in membranes. Membrane damage was assessed by leakage of a fluorescent probe entrapped in liposomes and by generation of thiobarbituric acid-reactive species (TBARS), while structural changes at the lipid bilayer were detected by small-angle $\mathrm{X}$-ray scattering. We observed that all compounds had similar singlet-oxygen quantum yields in ethanol, but only the photosensitizers that had higher membrane/solution partition (1,9-dimethyl methylene blue and DO15, the latter having the higher value) could permeabilize the lipid bilayer. Moreover, of these two photosensitizers, only DO15 altered membrane structure, a result that was attributed to its destabilization of higher order aggregates, generation of higher amounts of singlet oxygen within the membranes and effective electron-transfer reaction within its dimers. We concluded that membrane-based protocols can provide a better insight on the photodynamic efficiency of the photosensitizer.
\end{abstract}

\section{INTRODUCTION}

Photosensitization is the basis of photodynamic therapy (PDT), a clinical modality available for a variety of cancers and currently under considerable investigation for its application to treat microbial infections (1-5). One of the key elements in PDT is the photosensitizer (PS). Absorption of light causes excitation and the production of several reactive species, and subsequent damage to biomolecules and cell death. The excited state of the PS (usually the triplet excited state) can generate the reactive species either by type I or type II pathways, the former comprising electron or hydrogen transfer to or from a substrate and the latter involving energy transfer to molecular oxygen and the generation of singlet oxygen $\left({ }^{1} \mathrm{O}_{2}\right)$ (6). These basic action mechanisms seem to occur

*Corresponding author email: baptista@iq.usp.br (Mauricio S. Baptista)

(C) 2014 The American Society of Photobiology to different extents in all different classes of PS in use, such as phthalocyanine, porphyrin and phenothiazinium PS (7-10).

The search for more efficient PS is commonly performed by improving the efficiency of generation of light-induced reactive species, which is done by maximizing two main characteristics of the PS: absorption in the therapeutic window and quantum yield of ${ }^{1} \mathrm{O}_{2}$ generation $\left(\Phi_{\Delta}\right)$, which is considered to be the main species responsible for causing cell death $(5,11)$. Nevertheless, many studies in mammalian cell culture have highlighted that this strategy is not always the best way to proceed, showing the importance of subcellular localization to photodynamic damage $(12,13)$. Crystal violet, for example, localizes in mitochondria without being reduced. Under irradiation, this compound killed HeLa cells more efficiently than methylene blue (MB), a classical ${ }^{1} \mathrm{O}_{2}$ generator (14). Certainly, for prokaryotic cells and viruses the role of PS localization is more restricted, given their simpler internal compartmentalization.

Despite PDT being a multitarget strategy and relying on photodamage to several biomolecules and cellular structures (cytoplasmic membrane, organelles, cytoskeleton, etc.), the role of membrane binding of a PS is critical to define the extent of photoinduced membrane damage and consequently the efficiency of cell death $(7,8,15-18)$. This fact is well recognized for porphyrin and phthalocyanines PS. However, clear structure-activity relationships are still missing for several PS classes such as the phenothiazinium salts (19).

Phenothiazinium cations are composed of an oxidized ring system chromophore and attached auxochromic side groups, which contribute significantly to the polarity of the ion. Increased mammalian cell phototoxicity of this class of PS has been observed with more hydrophobic compounds. This enhanced activity was attributed mainly to an increase in $\Phi_{\Delta}$, resistance to reduction to the photodynamically inactive leuco form and higher cell uptake. Among the studied dyes, 1,9-dimethyl methylene blue (DMMB) and DO15 have superior photodynamic activity in many different biological systems (tumor cells, bacteria, virus and fungi) when compared to commercially available PS such as $\mathrm{MB}$ and toluidine blue $\mathrm{O}$ (TBO). Moreover, these more hydrophobic compounds usually exhibit larger light/dark cytotoxicity ratio $(20-32)$.

The aim of the current work is to clarify parameters that affect the ability of phenothiazinium ions to damage membranes, starting from the efficiency of membrane binding and progressing to analyze the properties of the ground and excited states of the PS 
in the membranes. In what follows, we compare different properties of a series of phenothiazinium salts composed by MB, TBO, DMMB and DO15 (Table 1). We paid special attention to the ability of PS, not only to promote membrane damage (indicated by leakage of a fluorescent probe and generation of products of lipid oxidation) but also to promote changes in the molecular architecture of the bilayer membrane, which should be important concerning the specificity of the photodynamic action.

\section{MATERIALS AND METHODS}

Materials. 5(6)-Carboxyfluorescein (CF), deuterium oxide $\left(\mathrm{D}_{2} \mathrm{O}\right)$, DMMB, MB, Sephadex G-50, sodium dodecyl sulfate (SDS), 2-thiobarbituric acid (TBA) and Triton X-100 were acquired from Sigma Aldrich (Saint Louis, MO). n-Butanol, chloroform, ethanol, phosphoric acid, sodium chloride $(\mathrm{NaCl})$, sodium hydroxide, TBO and tris(hydroxymethyl) aminomethane (Tris) were bought from Labsynth (Diadema, Brazil) SOLEC F soy lecithin was acquired from Solae (Saint Louis, MO), and contains $6 \%$ of monounsaturated lipids and $39 \%$ of polyunsaturated lipids (mass percent). DO15 was synthesized as previously reported (26). Except from TBO, which was crystallized following the procedure described by Pal and Schubert (33), all other chemicals were used without further purification. Milli-Q water was used for preparing all aqueous solutions. A $10 \mathrm{~mm}$ Tris buffer $(\mathrm{pH}=8)$ was used whenever buffered media were required ("Tris buffer"). All absorption or emission spectra were made in a Hellma quartz cuvette (Müllheim, Germany) of $1 \mathrm{~cm}$ optical path.

Photophysical parameters. Absorption spectra were recorded with a Shimadzu UV-2400-PC spectrophotometer (Kyoto, Japan) in the $400-800 \mathrm{~nm}$ range. Molar absorptivity values $\left(\varepsilon_{\max }\right)$ in the maximum absorption wavelength $\left(\lambda_{\max }\right)$ in ethanol were determined by recording absorption spectra as a function of PS concentration $(0.25-20 \mu \mathrm{M}$ range), and applying the Beer-Lambert law. Fluorescence spectra $(600-800 \mathrm{~nm}$ range, excitation at $580 \mathrm{~nm}$ ) were obtained with a Spex Fluorolog $1934 \mathrm{D}$ fluorometer. Fluorescence quantum yields $\left(\Phi_{\mathrm{f}}\right)$ in ethanol were calculated by measuring the area under the emission spectrum, using a $\mathrm{MB}$ solution in ethanol as a standard $\left(\Phi_{\mathrm{f}}=0.04\right)(34,35)$. Absorbance of sample and reference solutions was always kept below 0.1 at the excitation wavelength, to minimize the inner filter effect. $\Phi_{\Delta}$ and ${ }^{1} \mathrm{O}_{2}$ lifetimes in ethanol were determined using an Edinburgh Instruments timeresolved NIR fluorimeter (Livingston, UK) equipped with a liquid nitrogen cooled Hamamatsu R55009 photomultiplier (Bridgewater, NJ). A Continuum Surelite III Nd:YAG laser (wavelength: $532 \mathrm{~nm}$; pulse duration: $5 \mathrm{~ns}$; frequency of pulsation: $10 \mathrm{~Hz}$; Q-switch: $240 \mu \mathrm{s}$-Santa Clara, CA) was used to pump a dye laser emitting at $640 \mathrm{~nm}$ (Continuum Jaguar, with (2-(2-(4-(dimethylamino)phenyl)ethenyl)-6-methyl-4Hpyran-4-ylidene)propanedinitrile in ethanol). Phosphorescence decay curves at $1270 \mathrm{~nm}$ were fitted to first-order exponential decay for the determination of ${ }^{1} \mathrm{O}_{2}$ lifetime. For $\Phi_{\Delta}$ measurements, a $\mathrm{MB}$ solution in ethanol was used as a standard $\left(\Phi_{\Delta}=0.52\right)$ and all PS had absorbances between 0.2 and 0.3 at $640 \mathrm{~nm}(36,37)$.

Aggregation. The aggregation tendency of each phenothiazinium PS was studied at different ionic strengths by recording absorption spectra of $15 \mu \mathrm{m}$ PS solutions in water and in 3 and $5 \mathrm{M} \mathrm{NaCl}$ solutions, and comparing them with those obtained in pure ethanol. Measurements were also made with $15 \mu \mathrm{M}$ PS in $0.3 \mathrm{~m} \mathrm{NaCl}$ in Tris buffer with and without liposomes. To obtain a liposome suspension, soy lecithin films $(30 \mathrm{mg})$ were prepared on glass tubes by evaporation of a chloroform stock solution. The films were then hydrated with $1 \mathrm{~mL}$ of $0.3 \mathrm{~m} \mathrm{NaCl}$ in Tris buffer, and sonicated for $10 \mathrm{~min}$ in a USC-1400A ultrasonic bath (Unique, Indaiatuba, Brazil). This same method was employed whenever liposome suspensions were required. The final phospholipid concentration in each

Table 1. Chemical structures, photophysical properties and $\log P_{\mathrm{o} / \mathrm{w}}$ of the studied compounds. Photophysical properties $\left(\lambda_{\max }, \varepsilon^{\lambda \max }, \Phi_{\Delta}\right.$ and $\left.\Phi_{\mathrm{f}}\right)$ were determined in ethanol, using MB as standard for both $\Phi_{\Delta}$ and $\Phi_{\mathrm{f}}(35,37)$.

\begin{tabular}{lcccc}
\hline Designation and structure & $\varepsilon / 10^{4} \mathrm{~m}^{-1} \mathrm{~cm}^{-1}$ & $\lambda_{\max } / \mathrm{nm}$ & $\Phi_{\Delta}$ & $\Phi_{\mathrm{f}} / 10^{-2}$ \\
\hline $\mathrm{MB}$ & $9.6 \pm 1.5$ & 655 & 0.52 & 4 \\
\hline
\end{tabular}

TBO<smiles></smiles>

DMMB<smiles></smiles>

DO15<smiles></smiles>

$7.4 \pm 0.9$

$7.8 \pm 0.4$

670
$0.44 \pm 0.03$

$7.62 \pm 0.07$

$-0.21^{*}$

$\log P_{\mathrm{o} / \mathrm{w}}$ values marked with '*' were extracted from (65) and the one marked with '**' was extracted from (31). 
sample was $0.32 \mathrm{~mm}$, as determined by a colorimetric assay with ferrothiocyanate (38). To subtract the contribution of scattering to the absorption spectra of the studied liposome suspensions, a blank containing the same amount of liposomes (but no PS) was employed. Spectra were collected at $0,15,30,45$ and $60 \mathrm{~min}$ of incubation (Figure S1). This data showed that there is almost no change in the absorption spectra after $30 \mathrm{~min}$ of incubation. However, significant changes occurred from 0 to $15 \mathrm{~min}$.

To understand whether aggregation has major or minor effect on the photodynamic efficiency for each PS, we calculated the ratio between the absorbance at absorption maximum of monomer and aggregate peaks (M/A ratio), which were identified by the first derivative of the spectra with respect to wavelength. For the liposomal studies, spectra obtained after $60 \mathrm{~min}$ of incubation were employed $(39,40)$.

Membrane/solution partition. Liposome suspensions were prepared using $60 \mathrm{mg}$ of soy lecithin and $1 \mathrm{~mL}$ of $0.3 \mathrm{M} \mathrm{NaCl}$ in Tris buffer for hydration. Next, heavier liposomes were isolated by three consecutive cycles of sedimentation (centrifugation at $10000 \mathrm{rpm}$ for $3 \mathrm{~min}$ ) and resuspension of the sediment. Liposomes $(60 \mu \mathrm{L})$ were then incubated with $15 \mu \mathrm{M}$ PS $(1 \mathrm{~mL})$. Phospholipid concentration in this solution was $0.33 \mathrm{~mm}$ (38). After $60 \mathrm{~min}$ of incubation, a further centrifugation step separated the liposomal (containing bound PS) and aqueous fractions (16). The former fraction was dissolved in a $90 \mathrm{~mm}$ SDS solution containing $10 \%$ of Triton X-100, to solubilize lipids and at the same time avoid the presence of PS aggregates. The absorption spectrum of the resulting solution was recorded, being $\mathrm{Abs}_{\mathrm{L}}$ its maximum absorbance. By adding the same surfactant solution to $15 \mu \mathrm{M}$ PS solutions, the absorbance of $100 \%$ free dye $\left(\mathrm{Abs}_{0}\right.$, corrected for dilution) was measured. The partition of the PS between the membrane $(\mathrm{m})$ and the aqueous solution (s) was defined as being the logarithm of the distribution ratio $\left(P_{\mathrm{m} / \mathrm{s}}\right)$, so that:

$$
\log P_{\mathrm{m} / \mathrm{s}}=\log \left[\mathrm{Abs}_{\mathrm{L}} /\left(\mathrm{Abs}_{0}-\mathrm{Abs}_{\mathrm{L}}\right)\right]
$$

This value can be compared to the so-called logarithm of the octanol/ water partition coefficient $\left(\log P_{\mathrm{o} / \mathrm{w}}\right)$. The $60 \mathrm{~min}$ period was chosen based on the data presented in Figure S1 (see Aggregation and Supporting Materials).

Photophysics in interfaces. The same experimental setup used to determine $\Phi_{\Delta}$ and ${ }^{1} \mathrm{O}_{2}$ lifetimes in ethanol was also used to study ${ }^{1} \mathrm{O}_{2}$ generation in the presence of membranes. A liposome suspension was prepared from $30 \mathrm{mg}$ of soy lecithin, and $1 \mathrm{~mL}$ of $\mathrm{D}_{2} \mathrm{O}$ for hydration. Samples and a blank without PS contained $0.40 \mathrm{~mm}$ of phospholipids (38). The absorption spectrum of this latter was used to subtract the effects of scattering from the spectra of the samples. The PS concentration was chosen so that the corrected absorbance at $640 \mathrm{~nm}$ was close to 0.2 (all PS had approximately the same absorbance at this wavelength). The phosphorescence decay curves at $1270 \mathrm{~nm}$ were fitted to second-order exponential decay for the determination of ${ }^{1} \mathrm{O}_{2}$ lifetimes, using the F900 6.8.12 software (Edinburgh Instruments. Livingston, UK). The percentage contribution of each preexponential factor, weighted by its respective lifetime, was also calculated using this same software (41)

Triplet excited-state lifetimes were measured with LPF-111 laser flash photolysis equipment (Luzchem Research Inc., Ottawa, Canada) coupled to a Continuum Surelite II Nd:YAG laser (wavelength: $532 \mathrm{~nm}$, pulse duration: $5 \mathrm{~ns}$, Q-switch $290 \mu \mathrm{s}$ - Santa Clara, CA). As reported by Junqueira and co-workers, changes in absorbance in the $380-480 \mathrm{~nm}$ range can be used to detect the triplet excited state of $\mathrm{MB}$, due to triplet-triplet absorption (39). Working at $435 \mathrm{~nm}$, the triplet excited states of both DMMB and DO15 were studied. The curves representing the changes in the absorbance of the sample as a function of time were fitted to a first-order exponential decay, which was used to determine the triplet excited-state lifetime. The aggregation state (and hence the M/A ratio) of dyes can be controlled by varying the concentration of SDS. This effect can be explained considering that cationic PS (MB, TBO, DMMB and DO15) are attracted to the negatively charged SDS. At low SDS concentrations (ca. $1 \mathrm{~mm}$ ), the number of PS cations per surfactant aggregates is high, and dimerization occurs. In contrast, at high SDS concentration (ca. $50 \mathrm{~mm}$ ), spreading of the PS occurs and aggregation is avoided (39).

Concentrations of $8 \mu \mathrm{M}$ DMMB and $15 \mu \mathrm{M}$ DO15 were employed, so that both PS showed the same absorbance at $532 \mathrm{~nm}$ in a $50 \mathrm{~mm}$ SDS solution. DO15 was also studied at $1 \mathrm{~mm}$ SDS, but this same condition was unsuitable for studying dimerized DMMB (this PS formed other types of aggregates, as in $\mathrm{NaCl}$ solutions, see Fig. 1c). For this reason, a $7 \mathrm{~mm}$ SDS solution was used for DMMB. In this SDS concentration, DMMB had a similar M/A ratio as DO15 had in $1 \mathrm{~mm}$ SDS.

Photoinduced CF release from liposomes. A liposome suspension was prepared using $30 \mathrm{mg}$ of soy lecithin, and $1 \mathrm{~mL}$ of $50 \mathrm{~mm} C F$ in Tris buffer for hydration. This produced a liposome suspension with CF encapsulated in the inner compartment of liposomes. The nonencapsulated CF was removed by exclusion chromatography in a Sephadex G-50 column in equilibrium with $0.3 \mathrm{M} \mathrm{NaCl}$ in Tris buffer (42). The fraction containing liposomes was identified visually, and collected in a clean flask. Because CF concentration in the interior of liposomes is high enough to promote fluorescence self-quenching, an increase in CF fluorescence indicates leakage to the outer solution (43), and may be used to infer the occurrence of membrane damage. Small-angle X-ray scattering (SAXS) experiments confirmed that the liposomes prepared by this method were unilamellar liposomes (see Membrane structure), and dynamic light scattering measurements (data not shown) revealed that their diameter was in the $150-200 \mathrm{~nm}$ range. The suspension was always used in the same day as prepared.

Membrane damage quantification was carried out in a 96-well fluorescence microplate (Greiner Bio One-Frickenhausen, Germany). The lipid suspension volume was always $7 \mu \mathrm{L}$ and PS concentration was fixed at $15 \mu \mathrm{M}$ (except for the control, which had no PS). This lipid/PS ratio produced the best fluorescence signal, since lower PS concentrations did not release CF efficiently and higher PS concentrations yielded a lower fluorescence signal, probably because of PS interaction with CF. Each well was then filled with $0.3 \mathrm{M} \mathrm{NaCl}$ in Tris buffer, so that the final volume was always $300 \mu \mathrm{L}$. The measured phospholipid concentration in each well was $0.18 \mathrm{~mm}(38)$. The whole microplate was irradiated with a light emitting diode (LED), with maximum emission wavelength at $633 \mathrm{~nm}$ and $34 \mathrm{~W} \mathrm{~m}^{-2}$ irradiance at a $10 \mathrm{~cm}$ distance. The emission spectrum of the LED, superposed on the spectra of the four PS in the presence of liposomes (Fig. 1, full stars), can be found at Figure S2a. To support quantitative comparison between the PS, overlap integrals were calculated, i.e. the product of these dyes' absorption spectra (making no distinction between monomer and aggregates) and the emission spectrum of the LED (Figure S2b). The highest overlap integral was obtained by TBO and was normalized to 1. For MB, DMMB and DO15, we obtained the values of $0.85,0.49$ and 0.51 , respectively.

Fluorescence at $517 \mathrm{~nm}$ (I) was monitored as function of irradiation time with an Infinite M-200 Tecan microplate reader (Männedorf, Switzerland), operating with excitation at $480 \mathrm{~nm}$. At the end of the experiment, Triton X-100 was added to each well, and the fluorescence intensity was once again recorded $\left(I_{\mathrm{T}}\right)$. For each value of $I$, the percent of released $\mathrm{CF}$ was calculated:

$$
\% \mathrm{CF}_{\text {released }}=100 \%\left(I-I_{0}\right) /\left(I_{\mathrm{T}}-I_{0}\right)
$$

where $I_{0}$ is the initial fluorescence intensity (44)

$\% \mathrm{CF}_{\text {released }}$ was plotted as a function of time $(t)$, and when substantial membrane damage was observed, the curves were fitted to Boltzmann sigmoidal function:

$$
\% \mathrm{CF}_{\text {released }}=\mathrm{A}_{2}+\left(\mathrm{A}_{1}-\mathrm{A}_{2}\right) /\left[1+\mathrm{e}^{\left(t-t_{50}\right) / \mathrm{d} t}\right]
$$

where $\mathrm{A}_{1}$ is the initial $\% \mathrm{CF}_{\text {released }}$ value, $\mathrm{A}_{2}$ is the final $\% \mathrm{CF}_{\text {released }}$ value, $t_{50}$ is the time when $\% \mathrm{CF}_{\text {released }}$ equals $50 \%$ and $\mathrm{dt}$ is a parameter related to the duration of the period at which $\% \mathrm{CF}_{\text {released }}$ changes rapidly.

TBARS assay. Samples were prepared from $30 \mathrm{mg}$ soy lecithin films, which were hydrated with $0.3 \mathrm{M} \mathrm{NaCl}$ in Tris buffer, without CF. Each well of a 96-well fluorescence microplate was then filled with $30 \mu \mathrm{L}$ of the resulting lipid suspension, $30 \mu \mathrm{M}$ PS (or no PS, in the case of the control) and enough $0.3 \mathrm{M} \mathrm{NaCl}$ in Tris buffer to give a total of $300 \mu \mathrm{L}$. The measured phospholipid concentration in each well was $1.6 \mathrm{~mm}$ (38). A higher lipid concentration (compared to the one used at CF leakage experiments) was required for detecting TBARS, as well as to collect SAXS data (see Membrane structure). Sample irradiation was carried out with a LED with maximum emission wavelength at $633 \mathrm{~nm}$ and $68 \mathrm{~W} \mathrm{~m}^{-2}$ irradiance at a $10 \mathrm{~cm}$ distance. To compare these data with the profile of $\mathrm{CF}$ release, liposomes with entrapped $\mathrm{CF}$ were prepared and irradiated in the same conditions. 

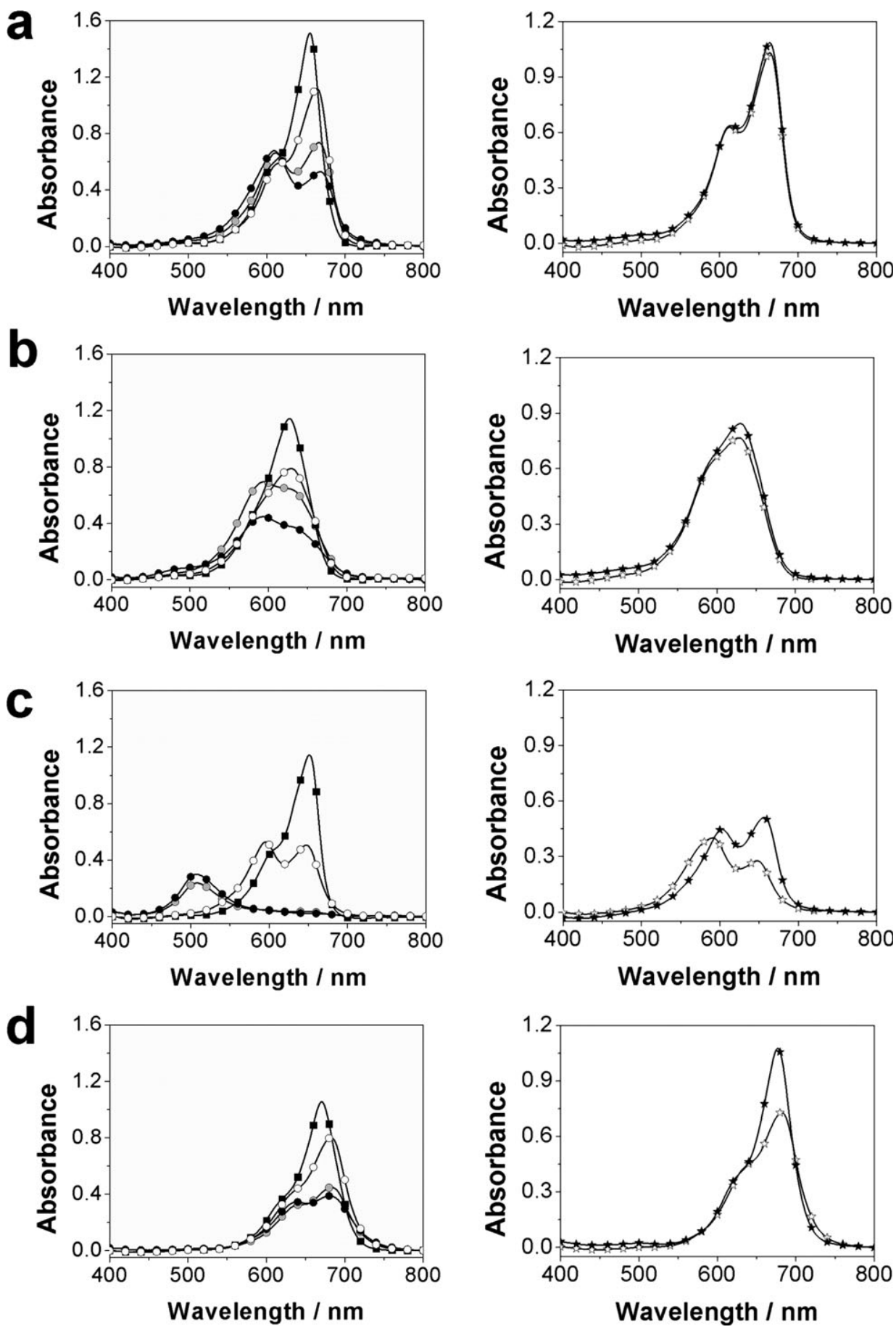

Figure 1. Electronic spectra of (a) MB, (b) TBO, (c) DMMB and (d) DO15 in six different conditions. Spectra on the left: ethanol (black squares), water (white circles), $3 \mathrm{~m} \mathrm{NaCl}$ aqueous solution (gray circles) and $5 \mathrm{~m} \mathrm{NaCl}$ aqueous solution (black circles). Spectra on the right: $0.3 \mathrm{~m} \mathrm{NaCl}$ in Tris buffer (white stars) and soy lecithin liposome suspension in $0.3 \mathrm{M} \mathrm{NaCl}$ in Tris buffer, after 60 min of incubation (black stars). All PS were at $15 \mu \mathrm{M}$ concentration.

For TBARS (TBA-reactive species) assay $(45,46), 150 \mu \mathrm{L}$ of sample was directly collected from 96 -well microplate at 0,2 and $5 \mathrm{~h}$ of irradiation. This volume was mixed with $150 \mu \mathrm{L}$ of $1 \%(\mathrm{~m} / \mathrm{v}) \mathrm{TBA}$ with $50 \mathrm{~mm}$ $\mathrm{NaOH}, 75 \mu \mathrm{L}$ of $20 \%(\mathrm{v} / \mathrm{v})$ phosphoric acid and $15 \mu \mathrm{L}$ of $10 \mathrm{M} \mathrm{NaOH}$. The mixture was kept at $85^{\circ} \mathrm{C}$ for $20 \mathrm{~min}$, after which $1 \mathrm{~mL}$ of $n$-butanol was added to extract the pink colored product. To enhance phase separation, samples were centrifuged at $500 \mathrm{rpm}$ for $4 \mathrm{~min}$. Given that different lipid oxidation-derived aldehydes can react with TBA-forming products that absorb at $532 \mathrm{~nm}$ (45), the available values of molar absorption of
TBA adducts does not allow accurate calculation of concentrations. Therefore, we preferred to only obtain absorption values, which were normalized as described below. The absorption spectrum of each sample was measured, and $\mathrm{Abs}^{532}-\mathrm{Abs}^{800}$ calculated for each of them, where $\mathrm{Abs}^{532}$ and $\mathrm{Abs}^{800}$ are the absorbances at 532 and $800 \mathrm{~nm}$, respectively. These values were normalized by the maximum $\mathrm{Abs}^{532}-\mathrm{Abs}^{800}$, obtained for DO15 after $5 \mathrm{~h}$ of irradiation. As the optical path and the dilution were the same for all samples, $100 \%\left(\mathrm{Abs}^{532}-\mathrm{Abs}^{800}\right) /\left(\mathrm{Abs}^{532}-\mathrm{Abs}^{800}\right)_{\mathrm{DO} 5(5 \mathrm{~h})}$ can be seen as a relative TBARS concentration (\% Relative [TBARS]). 
The calculation of \%Relative [TBARS] allows the quantification of different oxidation states of the model membranes.

Membrane structure. Samples were prepared in exactly the same way as for the TBARS assay (see TBARS assay), but in this case only DMMB and DO15 were examined. Phospholipid concentration in each sample was $1.6 \mathrm{~mm}$ (38). SAXS measurements were done at the SAXS1 beamline of the Brazilian Synchrotron Light Laboratory (LNLS, Campinas, Brazil), with radiation wavelength of $1.48 \AA$ and sample-to-detector distance of $900 \mathrm{~mm}$. The scattering vector modulus, $q$, defined as $q=\frac{4 \pi \sin \theta}{\lambda}\left(2 \theta\right.$ being the scattering angle), varied in the $0.007-0.25 \AA^{-1}$ range. The experimental intensities were corrected for background, buffer contributions, sample attenuation and detector homogeneity. ten as

The scattering intensity for a unilamellar lipid membrane can be writ-

$$
I(q)=k 2 \pi A P_{t}(q) q^{-2}
$$

where $k$ is related to the experimental setup; A is the area of the membrane basal plane and $P_{\mathrm{t}}(q)$ is the form factor of the bilayer cross-section (perpendicular to the basal plane), considered to be much smaller than the size of the plane A $(47) . P_{\mathrm{t}}(q)$ can be modeled supposing that each half of the membrane is constituted by three layers of different electron densities with respect to the solvent $\left(\rho_{\text {sol }}=0.33 e \AA^{-3}\right.$, where $e$ is the elementary charge) - the regions of the polar heads (with thickness $\mathrm{R}_{\mathrm{pol}}$ and electron density $\rho_{\text {pol }}$ ), hydrocarbon chains (with thickness $\mathrm{R}_{\mathrm{CH} 2}$ and electron density $\rho_{\mathrm{CH} 2}$ ) and hydrocarbon chain ends (with thickness $\mathrm{R}_{\mathrm{CH} 3}$ and electronic density $\left.\rho_{\mathrm{CH} 3}\right)$. This model is illustrated in Fig. 6a. The equations required to apply the model are described in reference (48), and SAXS data were analyzed with GENFIT software (49). During the fitting procedure, some of these parameters were allowed to vary within a narrow range, in accordance with data from the literature: $\mathrm{R}_{\mathrm{CH} 3}$ $\left(2.0 \AA<\mathrm{R}_{\mathrm{CH} 3}<3.5 \AA\right), \rho_{\mathrm{CH} 3}\left(0.15 e \AA^{-3}<\rho_{\mathrm{CH} 3}<0.25 e \AA^{-3}\right)$ and $\rho_{\mathrm{CH} 2}\left(0.25 e \AA^{-3}<\rho_{\mathrm{CH} 2}<0.30 e \AA^{-3}\right)(48)$. The other $P_{\mathrm{t}}(q)$ parameters were allowed to vary in a broader range.

Data treatment. Calculations were performed with Microsoft Excel 2010 (Microsoft Corporation, Redmond, WA). Graphs and curve fittings, except for ${ }^{1} \mathrm{O}_{2}$ measurements in the presence of liposomes and SAXS data (see Photophysics in interfaces and Membrane structure), were produced with OriginPro 8 (Origin Lab Corporation, Northamptom, MA). Results are presented in the form of mean \pm standard deviation, and error bars are standard deviations.

\section{RESULTS}

\section{Photophysical parameters}

As can be seen in Table 1, all PS have molar absorptivities in ethanol of $\sim 10^{5} \mathrm{M}^{-1} \mathrm{~cm}^{-1}$ and absorption maxima between 620 and $670 \mathrm{~nm}$ (Table 1 and Fig. 1-black squares). This absorption band is related to the main electronic transition of phenothiazinium salts (50). All these compounds have small $\Phi_{\mathrm{f}}$ (lower than 0.1 ) and high $\Phi_{\Delta}$. For MB, TBO and DO15, $\Phi_{\Delta}$ values are around 0.5 and for DMMB it is slightly higher, in accordance with the values found in the literature for $\mathrm{MB}$, TBO and DMMB (27). The higher $\Phi_{\Delta}$ of DMMB may be related with an enhanced triplet quantum yield. The measured ${ }^{1} \mathrm{O}_{2}$ lifetime was $\sim 14 \mu \mathrm{s}$ in all solutions, which is its expected lifetime in ethanol (51), indicating that none of the compounds quenched ${ }^{1} \mathrm{O}_{2}$.

\section{Aggregation}

Phenothiazinium dyes are known to aggregate in a manner dependent on the ionic strength and on the presence of negatively charged interfaces. This phenomenon is critical for this class of dyes, as it affects ${ }^{1} \mathrm{O}_{2}$ generation $(39,40)$. In the case of $\mathrm{MB}$, aggregation is easily observed by the appearance of another absorption peak shifted to the blue, demonstrating the presence of H-type dimers $(39,40)$. Here, we compared the aggregation tendency of the four PS in water as a function of the ionic strength (3 and $5 \mathrm{~m}$ aqueous $\mathrm{NaCl}$ solutions-Fig. 1, left and Table 2), in micellar environments and in the presence of membranes (Table 2). Aggregation was observed for all PS in both pure water and aqueous $\mathrm{NaCl}$ solutions, although at different levels. The wavelengths corresponding to absorption maximum of dimer peaks in water were 609 (MB), 594 (TBO), 595 (DMMB) and $637 \mathrm{~nm}$ (DO15). In both aqueous $\mathrm{NaCl}$ solutions (3 and $5 \mathrm{M})$, DMMB presented only one intense absorption peak (507 nm, Fig. 1c), which was further shifted to the blue if compared with the aggregate peaks of the other dyes and even with the peak that occurred for DMMB in pure water. It was also possible to observe, by visual inspection, pink colored particles in suspension. Ethanol caused the dissolution of the pink particles and shifted the absorption maxima, yielding the expected clear blue solution. These results indicated that DMMB formed higher order aggregates under these conditions (this effect was not observed for the other three PS) (52).

The ratio of the maximum absorption of monomer and aggregate peaks (M/A ratio) was used to compare the aggregation tendency of these cations (Table 2). In pure water, M/A ratios (2.0, $1.4,1.0$ and 1.8 for MB, TBO, DMMB and DO15, respectively) were larger than in salt solutions. DMMB showed a higher tendency to aggregation, with $\mathrm{M} / \mathrm{A}$ ratios of $0.2(3 \mathrm{M} \mathrm{NaCl})$ and 0.1 $(5 \mathrm{M} \mathrm{NaCl})$. TBO showed an intermediary tendency to aggregation, as indicated by its $\mathrm{M} / \mathrm{A}$ ratios of $0.9(3 \mathrm{M} \mathrm{NaCl})$ and 0.7 $(5 \mathrm{M} \mathrm{NaCl})$. The $\mathrm{M} / \mathrm{A}$ ratios for $\mathrm{MB}$ were slightly higher than those found for $\mathrm{TBO}$, being $1.1(3 \mathrm{M} \mathrm{NaCl})$ and $0.8(5 \mathrm{M} \mathrm{NaCl})$. Finally, DO15 had the lowest tendency to aggregation, as shown by its highest M/A ratios of $1.4(3 \mathrm{M} \mathrm{NaCl})$ and $1.1(5 \mathrm{M} \mathrm{NaCl})$.

The four PS were somehow aggregated in $0.3 \mathrm{M} \mathrm{NaCl}$ in Tris buffer, M/A ratios being 1.6, $1.2,0.7$ and 1.6 for $\mathrm{MB}$, TBO, DMMB and DO15, respectively (Fig. 1, right and Table 2). When the same measurement was carried out in the presence of liposomes (after $1 \mathrm{~h}$ of incubation), M/A ratios were increased

Table 2. Ratio between the absorbance at absorption maximum of monomer and aggregate(s) peaks ( $\mathrm{M} / \mathrm{A})$ in pure water, 3 and $5 \mathrm{M} \mathrm{NaCl,} 0.3 \mathrm{M} \mathrm{NaCl}$ in Tris buffer, soy lecithin liposome suspension in $0.3 \mathrm{~m} \mathrm{NaCl}$ in Tris buffer ( $60 \mathrm{~min}$ of incubation) and in SDS solutions. "High [SDS]" stands for a 50 mм SDS concentration, whereas "Low [SDS]" corresponds to 7 and 1 mm SDS for DMMB and DO15, respectively. PS concentration was $15 \mu \mathrm{M}$ in all measurements, except for DMMB $(8 \mu \mathrm{M})$ in "Low [SDS]".

\begin{tabular}{|c|c|c|c|c|c|c|c|}
\hline & Water & $3 \mathrm{M} \mathrm{NaCl}$ & $5 \mathrm{M} \mathrm{NaCl}$ & $\begin{array}{l}0.3 \mathrm{M} \mathrm{NaCl} \text { in } \\
\text { Tris buffer }\end{array}$ & $\begin{array}{c}0.3 \mathrm{M} \mathrm{NaCl} \text { in } \\
\text { Tris buffer }+ \text { liposomes }\end{array}$ & High [SDS] & Low [SDS] \\
\hline MB & 2.0 & 1.1 & 0.8 & 1.6 & 1.7 & - & - \\
\hline TBO & 1.4 & 0.9 & 0.7 & 1.2 & 1.3 & - & - \\
\hline DMMB & 1.0 & 0.2 & 0.1 & 0.7 & 1.1 & 2.6 & 1.0 \\
\hline DO15 & 1.8 & 1.4 & 1.1 & 1.6 & 2.6 & 2.6 & 0.9 \\
\hline
\end{tabular}


to: $1.7,1.3,1.1$ and 2.6 for MB, TBO, DMMB, DO15, respectively. Therefore, the overall effect of liposomes was to decrease PS aggregation. However, the M/A ratio of $\mathrm{MB}$ and $\mathrm{TBO}$ showed only subtle increases, whereas that of DMMB and DO15 showed prominent increases, i.e. 57 and $64 \%$, respectively.

\section{Membrane/solution partition of PS}

The extent of PS binding to the membranes is an important piece of information to have a complete understanding of membrane damage by photosensitization $(8,16)$. The lipophilicity parameter $\log P_{\mathrm{o} / \mathrm{w}}$ provides a qualitative approach to characterize the interaction of PS with membranes; however, accurate values are obtained only by performing direct membrane binding experiments (16). Here, PS partitioning between membrane and aqueous solution was determined by equilibration with liposomes and the separation of bound and free PS by centrifugation. DMMB and DO15 had much higher $\log P_{\mathrm{m} / \mathrm{s}} \quad(-0.33 \pm 0.04$ and $-0.06 \pm 0.04$, respectively) than $\mathrm{MB}$ and $\mathrm{TBO}(-1.55 \pm 0.08$ and $-1.26 \pm 0.01$, respectively), and hence bound to membranes to a greater extent than the latter cations. These higher $\log P_{\mathrm{m} / \mathrm{s}}$ values are related to their larger number of hydrophobic side groups/moieties (see Table 1). It is possible to observe that there is a linear relationship between $\log P_{\mathrm{m} / \mathrm{s}}$ and $\log P_{\mathrm{o} / \mathrm{w}}\left(R^{2}=0.95\right.$, Fig. 2), although other parameters are also important to explain membrane binding. For example, TBO, which is more polar than MB and has a smaller $\log P_{\mathrm{o} / \mathrm{w}}$, had a larger value of $\log P_{\mathrm{m} / \mathrm{s}}$. This is because TBO is more asymmetric than MB and consequently interacts more efficiently with membranes than $\mathrm{MB}$ $(16,53)$.

\section{Photophysics in interfaces}

Quantification of ${ }^{1} \mathrm{O}_{2}$ production at the lipid bilayer can provide information regarding the role of type II processes in membrane damage. The fitting of the ${ }^{1} \mathrm{O}_{2}$ phosphorescence decay curves to second-order exponential decays for PS in the presence of liposomes (Fig. 3c-f) yielded two lifetime values (Table 3). The longer lifetime ranged from 54 to $60 \mu \mathrm{s}$, depending on the PS, which is typical of the ${ }^{1} \mathrm{O}_{2}$ lifetime in $\mathrm{D}_{2} \mathrm{O}$ (51). The shorter lifetime ranged from 2.2 to $4.1 \mu$ s and was attributed to the lifetime

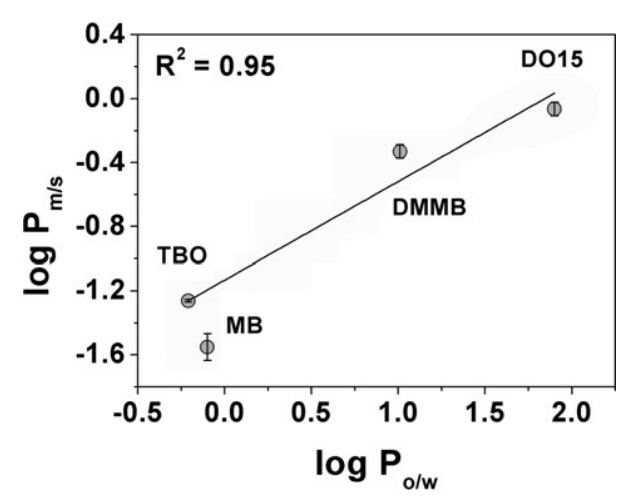

Figure 2. Plot of $\log P_{\mathrm{m} / \mathrm{s}}$ values, determined with soy lecithin liposomes in $0.3 \mathrm{M} \mathrm{NaCl}$ Tris buffer, as a function of its respective $\log P_{\mathrm{o} / \mathrm{w}}$ values. Each point (mean \pm standard deviation) corresponds to a different PS, which were all at $15 \mu \mathrm{M}$ concentration. A $R^{2}$ of 0.95 was obtained for a linear fit. The $\log P_{\mathrm{o} / \mathrm{w}}$ values were extracted from the literature $(31,65)$. on the membranes. Ehrenberg et al (54) estimated a lifetime of $12 \mu \mathrm{s}$ for singlet oxygen in egg yolk lecithin liposomes. In the present work, it was expected that the lifetime in liposomes would be shorter than this because soy lecithin is richer in polyunsaturated lipids (see Materials) (55). Note that the more hydrophobic dyes have a larger percentage of the ${ }^{1} \mathrm{O}_{2}$ decays happening on the membrane, 6.9 and $23 \%$ for DMMB and DO15, respectively, compared with 3.8 and 2.6 for $\mathrm{MB}$ and TBO, respectively. It is interesting to note that the percentage of the decay of singlet oxygen on the membrane is proportional to the amount of dye bound on the membrane. At this experimental condition, DO15 binds more efficiently to the membrane than DMMB. The emission intensity (taken at $3.8 \mu \mathrm{s}$ ) normalized by the absorbance at $640 \mathrm{~nm}$ was also higher for DO15 (almost double) than for the other three PS (Fig. 3b). It is clear therefore, that DO15 is much more efficient in delivering ${ }^{1} \mathrm{O}_{2}$ in the membrane.

Interfacial binding and aggregation affect the photophysical behavior of PS in several ways. For phenothiazinium salts, depending on the type of aggregate formed on the interfaces, two possibilities were shown to occur: (i) a physical deactivation mechanism, which simply reduces the excited-state lifetime by nonradiative decay; (ii) an electron-transfer reaction in the excited state, allowing the formation of semireduced and semioxidized radicals derived from the PS, which could facilitate radical-type chain reactions in the case of MB $(39,40,56)$. However, such behavior has not been investigated for DMMB and DO15, which bind strongly to membranes. To characterize the properties of dimers and monomers after light absorption, SDS micelles were employed, as these supramolecular assemblies allow facile control of the ratio of monomers to dimers. At low SDS concentration (few millimolar), dimers are favored and at $50 \mathrm{~mm}$ SDS only monomers are present $(39,40)$.

Transients due to triplet-triplet absorption showed that both DO15 $(15 \mu \mathrm{M})$ and DMMB $(8 \mu \mathrm{M})$ had similar triplet excited-state lifetimes in $50 \mathrm{~mm}$ SDS, being 1.9 and $1.8 \mu \mathrm{s}$ (Fig. 4a and c), respectively, similar to the value reported by Junqueira and coworkers for $\mathrm{MB}$ in the same concentration of surfactant $(1.5 \mu \mathrm{s})$. In this case, the triplet excited state of the PS returns to the ground state mainly by energy transfer to molecular oxygen, yielding ${ }^{1} \mathrm{O}_{2}$ $(39,40)$. When the SDS concentration was lowered to $1 \mathrm{~mm}$, DO15's (15 $\mu \mathrm{M}, \mathrm{M} / \mathrm{A}$ ratio of 0.9 - Table 2) triplet-triplet absorption increased substantially and the triplet excited-state lifetime fell to $30 \mathrm{~ns}$ (Fig. 4b), which has the same magnitude as that reported for $\mathrm{MB}$ in the same SDS concentration (40 ns). The increase in the triplet-triplet absorption and the decrease in the triplet excited-state lifetime, compared with the one observed at $50 \mathrm{~mm}$ SDS, can be explained by the increase in the intersystem crossing and by the dye-dye electron-transfer reaction in the excited state, which is faster than the energy transfer to molecular oxygen, favoring the formation of semioxidized and semireduced radicals of the PS $(39,40)$. To study DMMB $(8 \mu \mathrm{M})$ in a similar $\mathrm{M} / \mathrm{A}$ ratio, the same measurement was carried out for DMMB in a $7 \mathrm{~mm}$ SDS solution (M/A ratio of 1.0-Table 2). In this condition, no triplet-triplet signal was detected (Fig. 4d), meaning that SDS-induced DMMB dimers are photochemically inactive, i.e. after light absorption there is rapid energy dissipation and triplets are not produced. This behavior is different from DO15 dimers, which are photochemically active, generating higher amounts of triplets and inducing electron-transfer reactions in the excited state. 


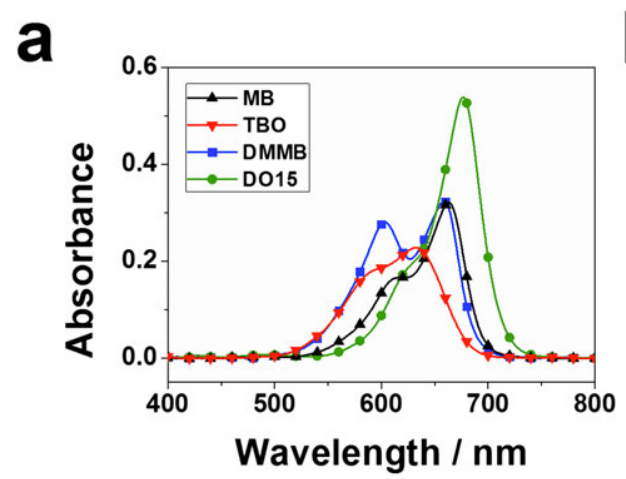

b
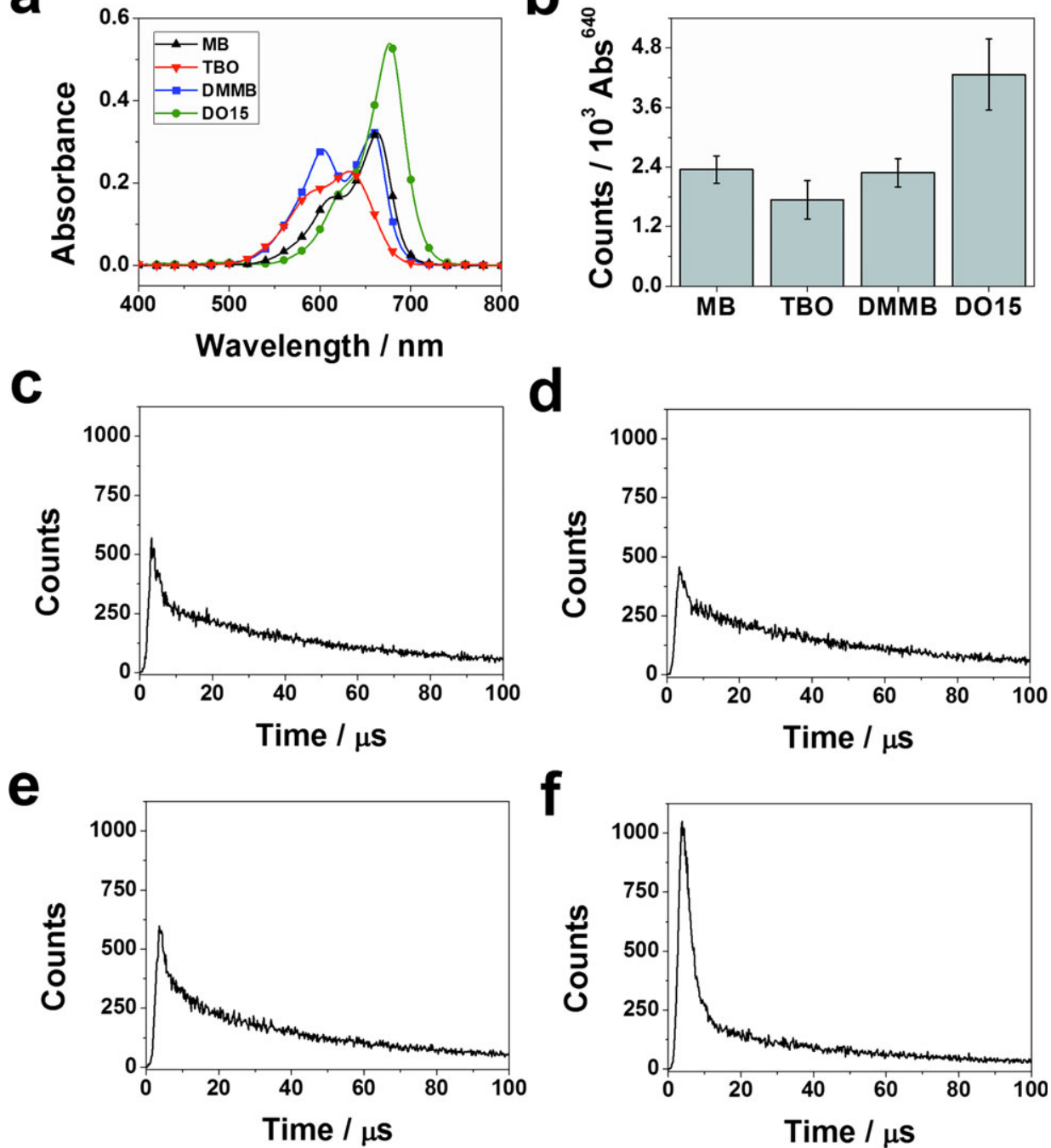

Figure 3. (a) Absorption spectra of $4.5 \mu \mathrm{M} \mathrm{MB}$ (black), $6 \mu \mathrm{M} \mathrm{TBO}$ (red), $8 \mu \mathrm{m}$ DMMB (blue) and $7 \mu \mathrm{M}$ DO15 (green) in $\mathrm{D}_{2} \mathrm{O}$ with soy lecithin liposomes. (b) Emission intensity at $1270 \mathrm{~nm}($ at $3.8 \mu \mathrm{s})$ normalized by absorbance at $640 \mathrm{~nm}\left(\mathrm{Abs}^{640}\right)$ for the phosphorescence decay curves presented at (c-f) for MB, TBO, DMMB and DO15, respectively.

Table 3. ${ }^{1} \mathrm{O}_{2}$ lifetimes $\left(\tau_{1}\right.$ and $\left.\tau_{2}\right)$ for the decays presented on Figure 3, considering a second-order exponential decay. Measurements were performed three times, and the range $\chi_{\text {red }}{ }^{2}$ informs the maximum and minimum reduced $\gamma^{2}$ values obtained. $\% \tau_{1}$ and $\% \tau_{2}$ are the percentage contribution of each preexponential factor, weighted by its respective lifetime. Each value represents mean \pm standard deviation.

\begin{tabular}{lccccc}
\hline & $\tau_{1} / \mu \mathrm{s}$ & $\tau_{2} / \mu \mathrm{s}$ & Range of $\chi_{\mathrm{red}}{ }^{2}$ & $\% \tau_{1}$ & $\% \tau_{2}$ \\
\hline MB & $2.2 \pm 0.3$ & $59 \pm 1$ & $1.014-1.105$ & $3.8 \pm 0.3$ & $96.2 \pm 0.3$ \\
TBO & $2.7 \pm 0.5$ & $60 \pm 2$ & $1.011-1.137$ & $2.6 \pm 0.6$ & $97.4 \pm 0.6$ \\
DMMB & $4.1 \pm 0.4$ & $54 \pm 1$ & $1.069-1.173$ & $6.9 \pm 0.4$ & $93.1 \pm 0.4$ \\
DO15 & $2.7 \pm 0.1$ & $54 \pm 2$ & $0.992-1.202$ & $23 \pm 2$ & $77 \pm 2$ \\
& & & & & \\
\hline
\end{tabular}

\section{Efficiency and characteristics of membrane damage}

To investigate and compare the efficiencies of membrane damage within this series of PS, liposomes containing the self-quenched fluorescent probe $\mathrm{CF}$ were irradiated for up to $120 \mathrm{~min}$ in the presence of MB, TBO, DMMB or DO15. As can be seen in Fig. 5a, both $\mathrm{MB}$ and $\mathrm{TBO}$ promoted almost no variation in $\mathrm{CF}$ fluorescence during irradiation, similar to the control without PS. In contrast, the emission intensity at $517 \mathrm{~nm}$ was greatly increased by DMMB and DO15, indicating the occurrence of CF leakage.

After $120 \mathrm{~min}$ of irradiation, DMMB and DO15 promoted almost the same end-point CF fluorescence, which was also similar to the fluorescence observed after the complete disruption of liposomes by addition of Triton X-100, indicating that $99 \pm 3 \%$ and $100 \pm 3 \%$ of the CF leaked in the presence of DMMB and DO15, respectively [see Eq. (2)]. The small variation in CF fluorescence seen with $\mathrm{MB}$ and $\mathrm{TBO}$ resulted in $3.1 \pm 0.6 \%$ and $3.8 \pm 0.7 \%$ of $\mathrm{CF}$ release, respectively. Although the final \% $\mathrm{CF}_{\text {released }}$ was similar for DMMB and DO15, complete CF leakage was achieved faster for DO15 than for DMMB, as shown by fitting these data with the Boltzmann function [Eq. (3)]. DO15 reached $50 \%$ of CF leakage (as shown by the $t_{50}$ parameter) after $44 \mathrm{~min}$, while DMMB took $56 \mathrm{~min}$ to release the fluorescence probe to the same extent. It is noteworthy that the absorption spectra of MB and TBO, and not those of DMMB and DO15, had the best overlap with the LED emission spectrum (see Photoinduced CF release from liposomes and Figure S2). DMMB and 

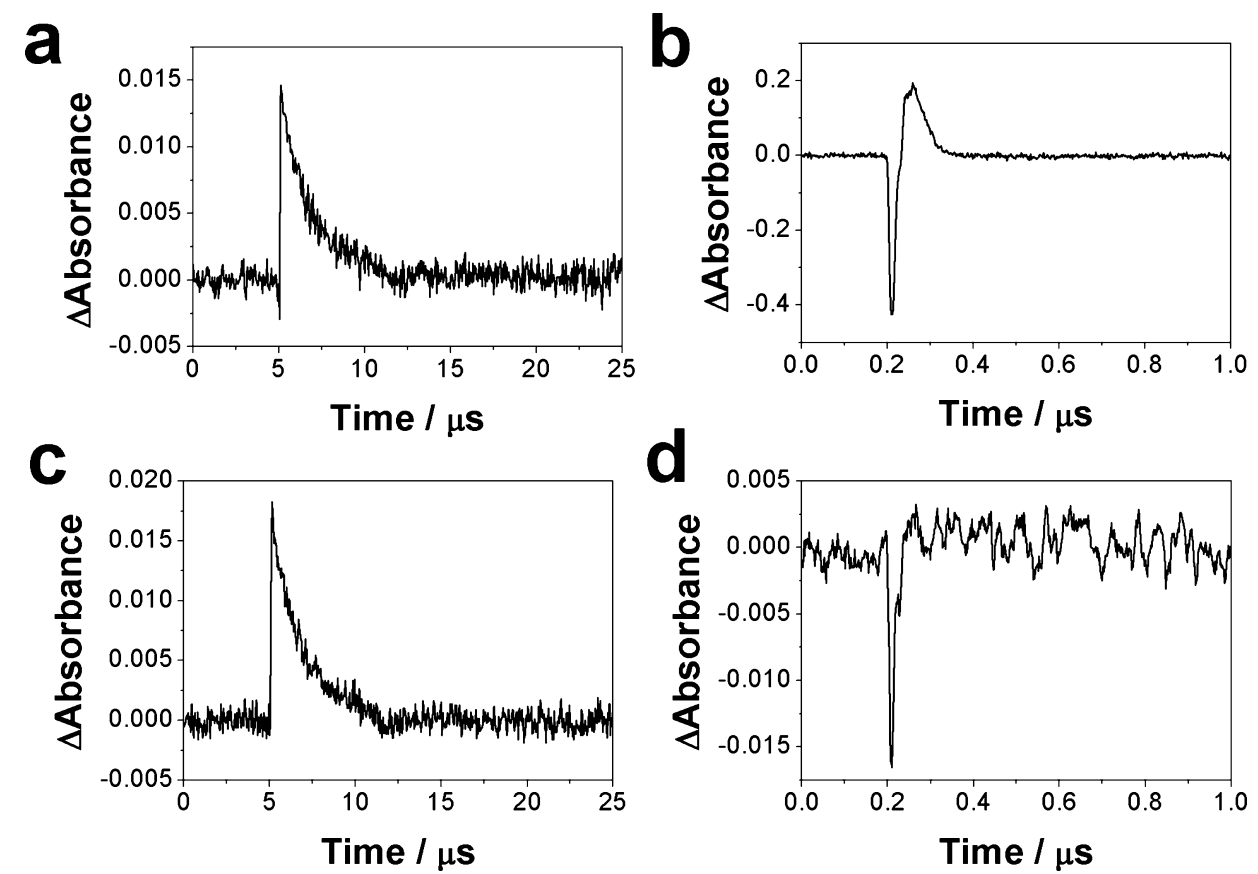

Figure 4. Laser flash photolysis transient absorption spectra obtained at $435 \mathrm{~nm}$ with excitation at $532 \mathrm{~nm}$ with (a) $15 \mu \mathrm{m}$ DO15 with $50 \mathrm{~mm}$ SDS, (b) $15 \mu \mathrm{m}$ DO15 with $1 \mathrm{~mm}$ SDS, (c) $8 \mu \mathrm{m}$ DMMB with 50 mм SDS and (d) $8 \mu \mathrm{m}$ DMMB with 7 mm SDS.

DO15 had the same overlap integral between their absorption spectra and the LED spectrum indicating that the same amount of photons was absorbed by these two dyes under these experimental conditions.

To gain insight about the chemical changes taking place at the membrane, a TBARS assay was used to access advanced stages of lipid oxidation. Too perform these experiments it was necessary to use liposomes and dyes at higher concentrations (see Materials and Methods). Similar to the result described above for liposomes prepared at the lower concentration regime, liposomes irradiated for $5 \mathrm{~h}$ in the presence of the MB and TBO did not release any measurable amount of CF. DMMB and DO15 did cause $\mathrm{CF}$ release, with the latter being also faster (data not presented). As can be seen in Fig. 5b, DO15 produced the higher concentration of TBARS, which was taken as reference (100\%) for comparisons that follow. Samples irradiated with $30 \mu \mathrm{M} \mathrm{MB}$ or TBO were no different than the control in terms of TBARS concentrations. On the other hand, irradiation in the presence of $30 \mu \mathrm{M}$ DMMB produced $67 \pm 5 \%$ and $74 \pm 9 \%$ of the reference value, after 2 and $5 \mathrm{~h}$ of irradiation, respectively. Therefore, there is indeed a relationship between CF release and TBARS generation.

To understand how the CF release was related with structural changes within the membranes, liposome photosensitization was performed in the presence of DMMB and DO15 and structural studies were carried out by SAXS (MB and TBO were not used in these studies because of their low values of $\log P_{\mathrm{m} / \mathrm{s}}, \%$ CFreleased and \%Relative [TBARS]). The experimental conditions were exactly the same as for TBARS. SAXS allowed the quantification of two properties of the liposome membranes, such as the thickness of the polar and nonpolar regions, as well as their respective electron densities (Fig. 6a). These measurements showed two important pieces of information for control liposomal membranes (presence of the PS and absence of irradiation): (i) liposome membranes consisted of a single lamella, as multilamellar systems would give rise to diffraction peaks in the scatter- ing curves $(48,57)$, which were not observed here; (ii) structural features of the soy lecithin-based membranes were not affected by the presence of the PS in the dark (Fig. 6b).

For DMMB there was almost no change on the profile of the SAXS scattering curves during irradiation (as seen in $I(q) \log$ scale plot on Fig. 6c), with only a small increase in the diffuse scattering noticeable at larger $q$ values. Such a diffuse scattering may be related to the presence of membrane fragments in solution as a consequence of photoinduced lipid oxidation (58). Structural fitting parameters, i.e. thickness and electron density of both the head groups and tails of the lipids (Table 4), did not change during irradiation within the evaluated experimental periods. Therefore, the presence of DMMB and light did not cause any significant change in the membrane structure noticeable by SAXS, even though CF permeated to the external compartment.

When the same experiment was carried out with DO15 (Fig. 6c), an increase in the diffuse scattering was also observed at larger q values. However, in this case, there were clearly more changes in the SAXS curves during irradiation, suggesting modifications in the lipid bilayer structure (Fig. 6c). In fact, fitting of the experimental data with the membrane model (Fig. 6d, solid lines) revealed that the main changes induced by photooxidation occurred in the polar region: $\mathrm{R}_{\mathrm{pol}}$ decreased by ca. of $2 \AA$ (from 12.7 to $9.9 \AA$, Table 4), accompanied by an increase in the polar electron density $\rho_{\text {pol }}$ (from $0.421 e \AA^{-3}$ to $0.471 e \AA^{-3}$, Table 4). Thus, under the photooxidation with DO15, the thickness of the polar shell that separates the outer buffer solution from the hydrophobic core decreased, and its electron density increased.

\section{DISCUSSION}

Many authors use $\Phi_{\Delta}$ as the main property to search for new and more efficient PS $(5,11)$. If $\Phi_{\Delta}$ in ethanol is taken solely into account to predict the photodynamic action of the four studied 
a

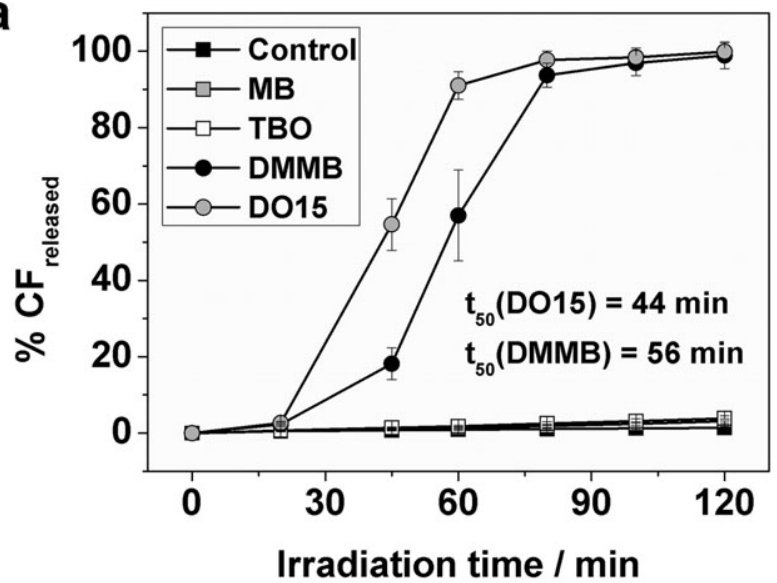

b

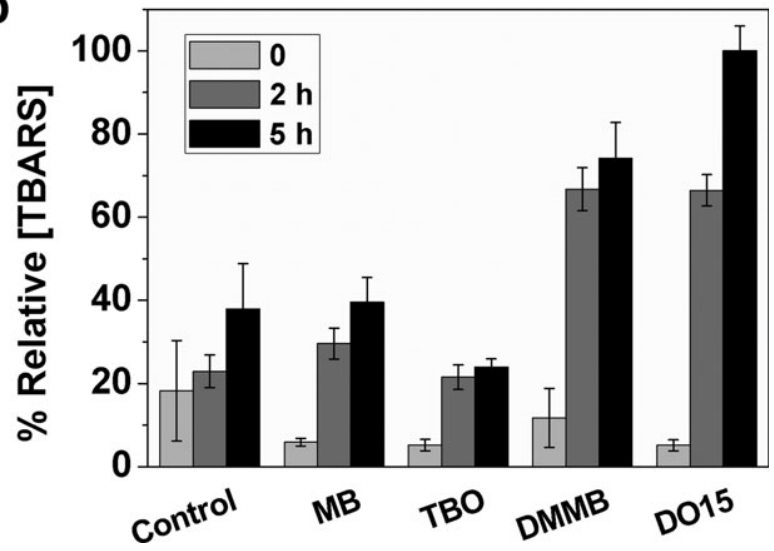

Figure 5. (a) $\% \mathrm{CF}_{\text {release }}$ as a function of irradiation time $(633 \mathrm{~nm} \mathrm{LED}$, with $34 \mathrm{~W} \mathrm{~m}^{-2}$ irradiance, at a $10 \mathrm{~cm}$ distance), using soy lecithin liposomes and $15 \mu \mathrm{M}$ PS in $0.3 \mathrm{M} \mathrm{NaCl}$ Tris buffer. $t_{50}$ values correspond to the time needed to reach half of the maximum fluorescence intensity, as determined by fitting the Boltzmann function to the experimental data [Eq. (3)]. (b)\%Relative [TBARS] for each PS as a function of irradiation time. Soy lecithin liposomes with $30 \mu \mathrm{M}$ PS (or no PS, as in the control) were irradiated with a $633 \mathrm{~nm} \operatorname{LED}\left(68 \mathrm{~W} \mathrm{~m}^{-2}\right.$ irradiance at a $10 \mathrm{~cm}$ distance). Each point/bar represents mean \pm standard deviation.

PS, one should not expect great differences among MB, TBO and DO15 in terms of damaging membranes. Indeed, based solely on its $\Phi_{\Delta}$ value, DMMB would be expected to be the best PS. Nonetheless, although it was effective in releasing CF, its $t_{50}$ parameter was larger than that of DO15, it generated less TBARS and promoted no detectable structural modification in the membrane, contradicting this hypothesis.

There are several experimental and theoretical reports indicating that side groups affect the interaction of the PS with membranes $(8,15,16,53)$. By comparing the efficiency of the series of phenothiazinium cations studied here, it is clear that those PS producing higher CF leakage are the ones with more positive log $P_{\mathrm{m} / \mathrm{s}}$ values. This relation can be understood if one considers that a higher $\log P_{\mathrm{m} / \mathrm{s}}$ value increases the generation of reactive species close to the unsaturated lipid chains, and hence raises the probability that lipid oxidation takes place. This knowledge is not new, as the authors and others have also observed that amphiphilic PS are more efficient in terms of causing membrane damage $(7,8,15-18,53)$.

Nevertheless, the effect of $\log P_{\mathrm{m} / \mathrm{s}}$ is not limited to a matter of PS concentration. The current results show that aggregation, photophysical and photochemical parameters are also affected by the interaction with the membrane. Aggregation is governed by several factors such as PS concentration, temperature and ionic strength. For example, increasing ionic strength decreases the electrostatic repulsion between two monomers, and facilitates aggregation. Intermolecular forces (i.e. van der Waals and London dispersion), molecular geometry and hydrophobicity also play a role in aggregation. The outcome of this latter property is related to the hydrophobic effect: the higher the entropic gain of releasing water molecules when two dyes interact with each other, the higher the dimerization constant. This explains why $\mathrm{MB}$ and TBO presented lower aggregation tendency than DMMB, as these two are the more hydrophilic of the studied PS. The effect of structure is clear for DMMB and DO15: although the former is less hydrophobic than the latter, it faces less steric constraints than DO15, explaining why it aggregated the most. The lower aggregation of DO15 can be attributed to steric hindrance imposed by its bulky terminal rings (Table 1), which also avoid the formation of larger aggregates, like those exhibited by DMMB. Hence, the spatial constraints imposed by molecular geometry play a more important role than intermolecular forces and the hydrophobic effect, being therefore a decisive factor. This conclusion has also been observed for other classes of PS. For example, an "L type" molecular scaffold totally abolishes the aggregation tendency of chlorins $(59,60)$.

The disaggregation of phenothiazinium PS in the presence of membrane is in agreement with the disaggregation observed in high SDS concentration (39). Membranes provide electrostatic and hydrophobic interacting sites, competing favorably with dye-dye interactions. In this work, all PS exhibited an increase in M/A ratios in the presence of membranes. The effect was more prominent for DMMB and DO15 that bind more effectively to membranes.

The decay curves of singlet-oxygen emission obtained in the presence of liposomes illustrated well one of the main concepts: that it is necessary to study excited-state photosensitiser processes in membranes to establish reasonable structure-activity relationships. Note that the amount of ${ }^{1} \mathrm{O}_{2}$ decay within the membrane (Table 3 ) follows the same order as the efficiency of $\mathrm{CF}$ release, i.e. $\mathrm{MB} \approx \mathrm{TBO}<\mathrm{DMMB}<\mathrm{DO} 15$. It is also possible to relate singlet-oxygen emission to the $\mathrm{M} / \mathrm{A}$ ratios in the presence of liposomes, MB, TBO and DMMB all being somewhat aggregated, and hence poorer ${ }^{1} \mathrm{O}_{2}$ generators than DO15, which delivered more singlet oxygen to the membranes.

The effect of aggregation was also shown to affect other photophysical properties. DMMB aggregates generated excited states that were deactivated before the formation of triplets, while dimers of DO15 caused an increase in the generation of triplets, which can engage in dye-dye electron-transfer reactions (Fig. 3c). These observations fit well with SAXS results that showed a larger structural change when membranes were treated with DO15 and light. This dye is more concentrated in the membrane than in the solution, is the best ${ }^{1} \mathrm{O}_{2}$ generator in membranes and also can generate more triplets and radicals species (semioxidized and semireduced radicals of the PS), if dimerized. Hence, DO15 can either facilitate type II or type I reactions effectively, the latter process allowing the propagation of lipid oxidation beyond the sole formation of lipid hydroperoxides by ${ }^{1} \mathrm{O}_{2}$. The generation of alkoxyl and peroxyl radicals induced by the type I process feeds the peroxidation chain reaction, leading to a more extensive formation of oxidized lipids and possibly to a richer composition of these (56). 


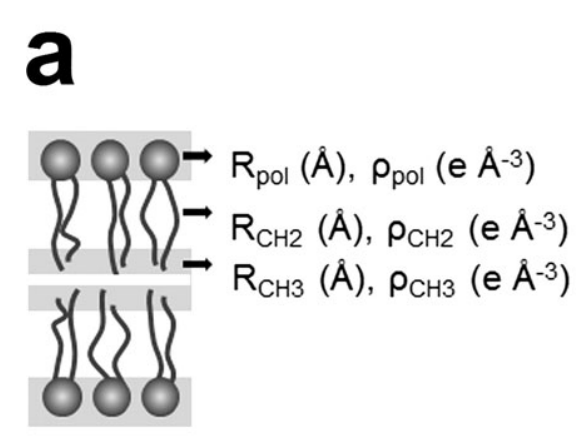

b
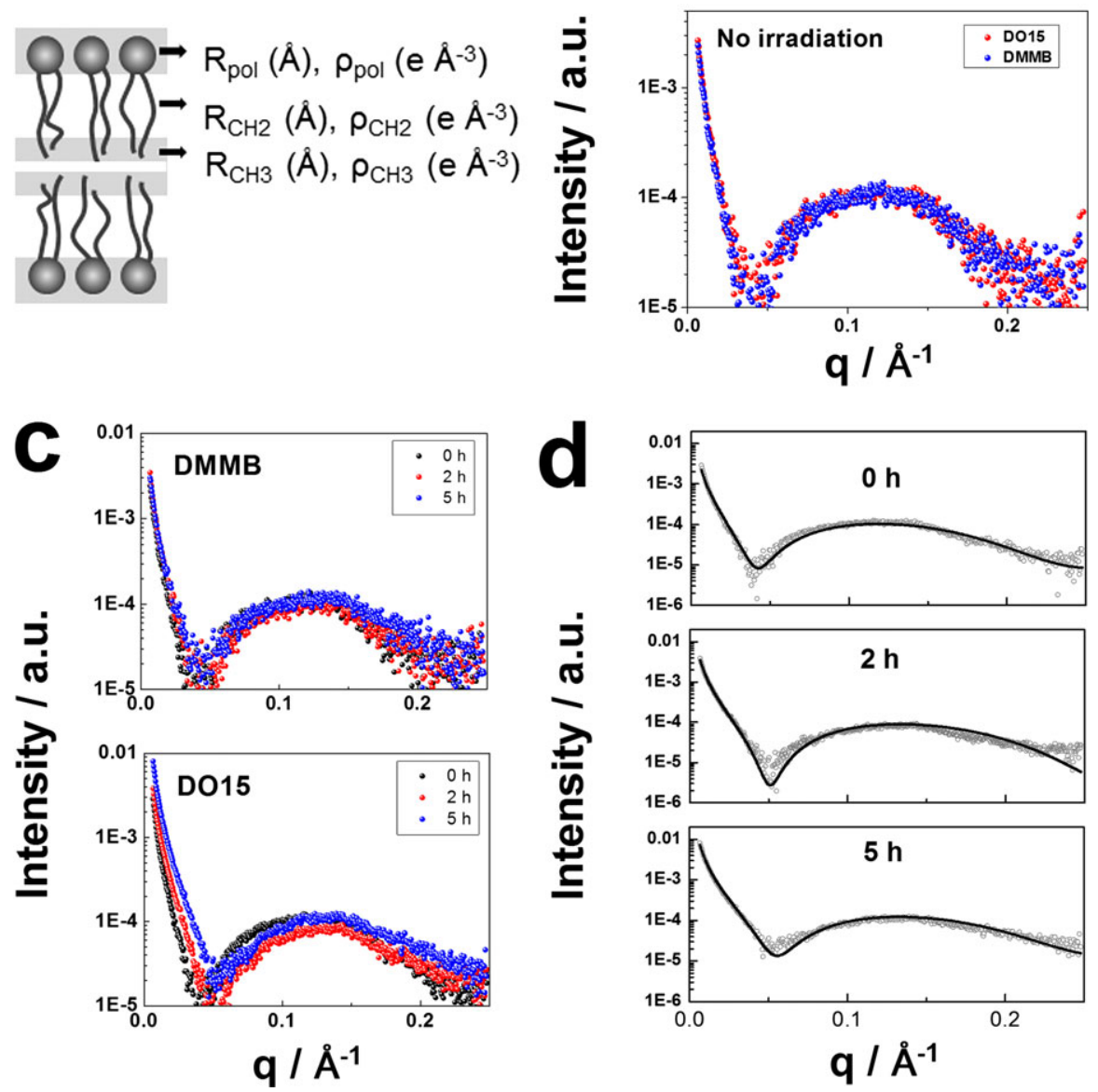

Figure 6. (a) Regions of the lipid bilayer considered in the model for $P_{\mathrm{t}}(q)$. $\mathrm{R}_{\mathrm{pol}}, \mathrm{R}_{\mathrm{CH} 2}$ and $\mathrm{R}_{\mathrm{CH} 3}$ correspond to the thickness of the polar head, hydrocarbon chain and hydrocarbon chain end regions, respectively. $\rho_{\mathrm{pol}}, \rho_{\mathrm{CH} 2}$ and $\rho_{\mathrm{CH} 3}$ correspond to the electron densities of these same regions, respectively. (b) Scattering curves obtained with soy lecithin liposomes in the presence of $30 \mu \mathrm{M}$ DMMB or DO15, without irradiation. Soy lecithin membrane in the absence of PS presented identical SAXS profile (data not shown for clarity). (c) Scattering curves obtained after 0, 2 and 5 h of irradiation of the same systems as (b), with a $633 \mathrm{~nm} \mathrm{LED}\left(68 \mathrm{~W} \mathrm{~m}^{-2}\right.$ irradiance at a $10 \mathrm{~cm}$ distance). In (d), experimental data obtained with DO15 are shown separately for each of the three different irradiation times along with the best fits (solid line) obtained by considering the scattering of large unilamellar vesicles [Eq. (4)].

Table 4. Fitting parameters [see Eq. (4)] obtained with the lipid bilayer model for soy lecithin liposomes irradiated in the presence of $30 \mu \mathrm{M}$ DMMB or DO15 with a $633 \mathrm{~nm}$ LED $\left(68 \mathrm{~W} \mathrm{~m}^{-2}\right.$ irradiance at a $10 \mathrm{~cm}$ distance).

\begin{tabular}{|c|c|c|c|c|c|c|}
\hline & \multicolumn{3}{|c|}{ DMMB } & \multicolumn{3}{|c|}{ DO15 } \\
\hline & $0 \mathrm{~h}$ & $2 \mathrm{~h}$ & $5 \mathrm{~h}$ & $0 \mathrm{~h}$ & $2 \mathrm{~h}$ & $5 \mathrm{~h}$ \\
\hline $\mathrm{R}_{\mathrm{pol}} / \AA$ & $12.7 \pm 0.4$ & $12.7 \pm 0.4$ & $12.7 \pm 0.4$ & $12.7 \pm 0.4$ & $9.0 \pm 0.5$ & $9.9 \pm 0.5$ \\
\hline $\mathrm{R}_{\mathrm{CH} 2} / \AA_{0}$ & $10.9 \pm 0.2$ & $10.9 \pm 0.2$ & $10.9 \pm 0.2$ & $10.9 \pm 0.2$ & $10.7 \pm 0.2$ & $10.7 \pm 0.2$ \\
\hline $\mathrm{R}_{\mathrm{CH} 3} / \mathrm{A}$ & $2.55 \pm 0.05$ & $2.55 \pm 0.05$ & $2.55 \pm 0.05$ & $2.55 \pm 0.05$ & $2.55 \pm 0.05$ & $2.55 \pm 0.05$ \\
\hline$\rho_{\text {pol }} / e \AA_{\circ}^{-3}$ & $0.421 \pm 0.002$ & $0.421 \pm 0.002$ & $0.421 \pm 0.002$ & $0.421 \pm 0.002$ & $0.463 \pm 0.004$ & $0.471 \pm 0.004$ \\
\hline$\rho_{\mathrm{CH} 2} / e \AA_{0}^{-3}$ & $0.288 \pm 0.002$ & $0.288 \pm 0.002$ & $0.288 \pm 0.002$ & $0.288 \pm 0.002$ & $0.288 \pm 0.002$ & $0.288 \pm 0.002$ \\
\hline
\end{tabular}

Analysis of SAXS curves showed that the electron density contrast of the polar head groups region is increased by irradiation in the presence of DO15. Hydroperoxyl and other oxygenated groups attached to the carbonic chain are brought to the membrane surface due to more favorable interaction with the solvent than with the nonpolar lipid chains. Structural changes due to alterations in the packing parameter have already been demonstrated both theoretically and experimentally for lipid hydroperoxides, and provide a way of reasoning the structural changes provoked by DO15 (61,62). Mason and co-workers also observed a decrease in the overall thickness of the membrane, using a classical Fenton reaction as a source of free radicals to induce lipid oxidation (ferrous sulfate/ascorbate system). The main changes they observed occurred at the 
carbonic chains and carbonic chain ends, and were attributed to the breakage of lipid chains (63). Note, however, that in this work there was no observable shrinking in the hydrophobic region by $\mathrm{SAXS}$, once $\mathrm{R}_{\mathrm{CH} 2}$ and $\mathrm{R}_{\mathrm{CH} 3}$ values (Table 4) remained constant under irradiation.

It may be inferred that the structural changes detected by SAXS should be a combination of the structural effects due to the different types of oxidized lipids and their quantity, which may be specific to photosensitization-induced oxidation. The detected structural changes do not correlate exactly with TBARS generation, as DMMB had the same amount of TBARS as D015 after $2 \mathrm{~h}$ of irradiation, but showed no membrane structural changes. Hence, other kinds of oxidation reactions may be important for the architectural changes taking place at the lipid bilayer.

This work has demonstrated that the most efficient way to damage membranes would be to use a PS that binds strongly to the membrane, but at the same time avoiding aggregates that suffer quick excited-state deactivation. Although there is still some controversy concerning the spatial range in which the photodynamic mechanism acts, most researchers believe that it is highly localized because of the short lifetime of ${ }^{1} \mathrm{O}_{2}$ in aqueous solution (64). The results of this work agree with this picture, adding a more detailed mechanistic explanation of the localized action of PDT.

\section{CONCLUSION}

In agreement with results obtained in living cells, the membrane damage efficiency followed the order DO15 $>$ DMMB $>$ $\mathrm{MB} \approx \mathrm{TBO}$. For these photosensitizers, structure-activity relationships may be understood by quantifying membrane interaction in the first place but also by characterizing the details of the PS properties in membranes, i.e. the interactions and reactions between PS and membranes. We believe that this work also contributes to the literature by describing some methods and experimental protocols that were adapted and/or developed to obtain information of the PS properties in the membranes (aggregation state, triplet excited state and ${ }^{1} \mathrm{O}_{2}$ decays and structure of the lipid bilayer). Membrane-based protocols can provide a better search mechanism for more efficient PS and, at the same time, allow understanding of the mechanisms at a deeper level, which is not possible with cells.

Acknowledgements-FAPESP is acknowledged for the financial support of this research (grant No. 2012/50680). Authors also acknowledge LNLS for SAXS facilities, and individual FAPESP and CNPq research fellowships.

\section{SUPPORTING INFORMATION}

Additional Supporting Information may be found in the online version of this article:

Figure S1. Absorption spectra $15 \mu \mathrm{M}$ PS in $0.3 \mathrm{M} \mathrm{NaCl}$ in Tris buffer containing soy lecithin liposomes. Data was aquired at $0,15,30,45$ and $60 \mathrm{~min}$ of incubation, for (a) MB, (b) TBO, (c) DMMB and (d) DO15.

Figure S2. (a) Black axis: absorption spectra $15 \mu \mathrm{M}$ PS in $0.3 \mathrm{M} \mathrm{NaCl}$ in Tris buffer containing soy lecithin liposomes (60 min of incubation). Grey axis: emission spectrum of the LED used in the experiment, normalized by its maximum inten- sity. (b) Relative overlap integral resulting from the integration of the product of each absorption spectrum and the LED emission spectrum, normalized by the value obtained for TBO.

\section{REFERENCES}

1. Anand, S., B. J. Ortel, S. P. Pereira, T. Hasan and E. V. Maytin (2012) Biomodulatory approaches to photodynamic therapy for solid tumors. Cancer Lett. 326, 8-16.

2. Baptista, M. S. and M. Wainwright (2011) Photodynamic antimicrobial chemotherapy (PACT) for the treatment of malaria, leishmaniasis and trypanosomiasis. Braz. J. Med. Biol. Res. 44, 1-10.

3. Dolmans, D. E. J. G. J., D. Fukumura and R. K. Jain (2003) Photodynamic therapy for cancer. Nat. Rev. Cancer 3, 380-387.

4. Hamblin, M. R. and T. Hasan (2004) Photodynamic therapy: a new antimicrobial approach to infectious disease? Photochem. Photobiol. Sci. 3, 436-450.

5. Henderson, B. W. and T. J. Dougherty (1992) How does photodynamic therapy work. Photochem. Photobiol. 55, 145-157.

6. Foote, C. S. (1968) Mechanisms of photosensitized oxidation. There are several different types of photosensitized oxidation which may be important in biological systems. Science 162, 963970.

7. Pavani, C., Y. Iamamoto and M. S. Baptista (2012) Mechanism and efficiency of cell death of type II photosensitizers: effect of zinc chelation. Photochem. Photobiol. 88, 774-781.

8. Pavani, C., A. F. Uchoa, C. S. Oliveira, Y. Iamamoto and M. S. Baptista (2009) Effect of zinc insertion and hydrophobicity on the membrane interactions and PDT activity of porphyrin photosensitizers. Photochem. Photobiol. Sci. 8, 233-240.

9. Nyokong, T. (2007) Effects of substituents on the photochemical and photophysical properties of main group metal phthalocyanines. Coord. Chem. Rev. 251, 1707-1722.

10. Tardivo, J. P., M. Wainwright and M. S. Baptista (2012) Local clinical phototreatment of herpes infection in Sao Paulo. Photodiagn. Photodyn. Ther. 9, 118-121.

11. DeRosa, M. C. and R. J. Crutchley (2002) Photosensitized singlet oxygen and its applications. Coord. Chem. Rev. 233, 351-371.

12. Castano, A. P., T. N. Demidova and M. R. Hamblin (2004) Mechanisms in photodynamic therapy: part one-photosensitizers, photochemistry and cellular localization. Photodiagn. Photodyn. Ther. 1, 279-293.

13. Kessel, D., Y. Luo, Y. Q. Deng and C. K. Chang (1997) The role of subcellular localization in initiation of apoptosis by photodynamic therapy. Photochem. Photobiol. 65, 422-426.

14. Oliveira, C. S., R. Turchiello, A. J. Kowaltowski, G. L. Indig and M. S. Baptista (2011) Major determinants of photoinduced cell death: subcellular localization versus photosensitization efficiency. Free Radical Biol. Med. 51, 824-833.

15. Cordeiro, R. M., R. Miotto and M. S. Baptista (2012) Photodynamic efficiency of cationic meso-porphyrins at lipid bilayers: insights from molecular dynamics simulations. J. Phys. Chem. B 116, 1461814627.

16. Engelmann, F. M., I. Mayer, D. S. Gabrielli, H. E. Toma, A. J. Kowaltowski, K. Araki and M. S. Baptista (2007) Interaction of cationic meso-porphyrins with liposomes, mitochondria and erythrocytes. J. Bioenerg. Biomembr. 39, 175-185.

17. Lavi, A., H. Weitman, R. T. Holmes, K. M. Smith and B. Ehrenberg (2002) The depth of porphyrin in a membrane and the membrane's physical properties affect the photosensitizing efficiency. Biophys. J. 82, 2101-2110.

18. Rokitskaya, T. I., M. Block, Y. N. Antonenko, E. A. Kotova and P. Pohl (2000) Photosensitizer binding to lipid bilayers as a precondition for the photoinactivation of membrane channels. Biophys. J. 78, 2572-2580.

19. Wainwright, M. (2005) The development of phenothiazinium photosensitisers. Photodiagn. Photodyn. Ther. 2, 263-272.

20. Mellish, K. J., R. D. Cox, D. I. Vernon, J. Griffiths and S. B. Brown (2002) In vitro photodynamic activity of a series of methylene blue analogues. Photochem. Photobiol. 75, 392-397. 
21. Phoenix, D. A., Z. Sayed, S. Hussain, F. Harris and M. Wainwright (2003) The phototoxicity of phenothiazinium derivatives against Escherichia coli and Staphylococcus aureus. FEMS Immunol. Med. Microbiol. 39, 17-22.

22. Rice, L., M. Wainwright and D. A. Phoenix (2000) Phenothiazine photosensitizers. III. Activity of methylene blue derivatives against pigmented melanoma cell lines. J. Chemother. 12, 94-104.

23. Rodrigues, G. B., M. Dias-Baruffi, N. Holman, M. Wainwright and G. U. L. Braga (2013) In vitro photodynamic inactivation of Candida species and mouse fibroblasts with phenothiazinium photosensitisers and red light. Photodiagn. Photodyn. Ther. 10, 141-149.

24. Rodrigues, G. B., L. K. S. Ferreira, M. Wainwright and G. U. L. Braga (2012) Susceptibilities of the dermatophytes Trichophyton mentagrophytes and $\mathrm{T}$. rubrum microconidia to photodynamic antimicrobial chemotherapy with novel phenothiazinium photosensitizers and red light. J. Photochem. Photobiol. B, Biol. 116, 89-94.

25. Wagner, S. J., A. Skripchenko, D. Robinette, J. W. Foley and L. Cincotta (1998) Factors affecting virus photoinactivation by a series of phenothiazine dyes. Photochem. Photobiol. 67, 343-349.

26. Wainwright, M., K. Meegan and C. Loughran (2011) Phenothiazinium photosensitisers IX. Tetra- and pentacyclic derivatives as photoantimicrobial agents. Dyes Pigm. 91, 1-5.

27. Wainwright, M., D. A. Phoenix, L. Rice, S. M. Burrow and J. Waring (1997) Increased cytotoxicity and phototoxicity in the methylene blue series via chromophore methylation. J. Photochem. Photobiol. B, Biol. 40, 233-239.

28. Wainwright, M., H. Smalley, O. Scully and E. Lotfipour (2012) Comparative photodynamic evaluation of new phenothiazinium derivatives against Propionibacterium acnes. Photochem. Photobiol. $\mathbf{8 8}, 523-526$.

29. Walker, I., S. A. Gorman, R. D. Cox, D. I. Vernon, J. Griffiths and S. B. Brown (2004) A comparative analysis of phenothiazinium salts for the photosensitisation of murine fibrosarcoma (RIF-1) cells in vitro. Photochem. Photobiol. Sci. 3, 653-659.

30. Ball, D. J., Y. Luo, D. Kessel, J. Griffiths, S. B. Brown and D. I Vernon (1998) The induction of apoptosis by a positively charged methylene blue derivative. J. Photochem. Photobiol. B, Biol. 42, $159-163$.

31. Noodt, B. B., G. H. Rodal, M. Wainwright, Q. Peng, R. Horobin, J. M. Nesland and K. Berg (1998) Apoptosis induction by different pathways with methylene blue derivative and light from mitochondrial sites in V79 cells. Int. J. Cancer 75, 941-948.

32. Peng, Q. A., S. B. Brown, J. Moan, J. M. Nesland, M. Wainwright, J. Griffths, B. Dixon, J. Crusesawyer and D. Vernon (1993) Biodistribution of a methylene-blue derivative in tumor and normal-tissues of rats. J. Photochem. Photobiol. B, Biol. 20, 63-71.

33. Pal, M. and M. Schubert (1962) Measurement of the stability of metachromatic compounds. J. Am. Chem. Soc. 84, 4384-4393.

34. Eaton, D. (1988) Reference materials for fluorescence measurement. Pure Appl. Chem. 60, 1107-1114.

35. Olmsted, J. (1979) Calorimetric determinations of absolute fluorescence quantum yields. J. Phys. Chem. 83, 2581-2584.

36. Cosa, G. and J. C. Scaiano (2004) Laser techniques in the study of drug photochemistry. Photochem. Photobiol. 80, 159-174.

37. Wilkinson, F., W. P. Helman and A. B. Ross (1993) Quantum yields for the photosensitized formation of the lowest electronically excited singlet-state of molecular-oxygen in solution. J. Phys. Chem. Ref. Data 22, 113-262.

38. Stewart, J. C. M. (1980) Colorimetric determination of phospholipids with ammonium ferrothiocyanate. Anal. Biochem. 104, 10-14.

39. Junqueira, H. C., D. Severino, L. G. Dias, M. S. Gugliotti and M. S. Baptista (2002) Modulation of methylene blue photochemical properties based on adsorption at aqueous micelle interfaces. Phys. Chem. Chem. Phys. 4, 2320-2328.

40. Severino, D., H. C. Junqueira, M. Gugliotti, D. S. Gabrielli and M. S. Baptista (2003) Influence of negatively charged interfaces on the ground and excited state properties of methylene blue. Photochem. Photobiol. 77, 459-468.

41. Berezin, M. Y., H. Lee, W. Akers, G. Nikiforovich and S. Achilefu (2007) Ratiometric analysis of fluorescence lifetime for probing binding sites in albumin with near-infrared fluorescent molecular probes. Photochem. Photobiol. 83, 1371-1378.

42. Martins, R. M., R. Amino, K. R. Daghastanli, I. M. Cuccovia, M. A. Juliano and S. Schenkman (2008) A short proregion of trialysin, a pore-forming protein of Triatoma infestans salivary glands, controls activity by folding the N-terminal lytic motif. FEBS J. 275, 994 1002.

43. Weinstein, J. N., S. Yoshikami, P. Henkart, R. Blumenthal and W. A. Hagins (1977) Liposome-cell interaction - transfer and intracellular release of a trapped fluorescent marker. Science 195, 489-492.

44. Au, S., N. D. Weiner and J. Schacht (1987) Aminoglycoside antibiotics preferentially increase permeability in phosphoinositide-containing membranes - a study with carboxyfluorescein in liposomes. Biochim. Biophys. Acta 902, 80-86.

45. Hoyland, D. V. and A. J. Taylor (1991) A review of the methodology of the 2-thiobarbituric acid test. Food Chem. 40, 271-291.

46. Rodrigues, T., L. P. de Franca, C. Kawai, P. A. de Faria, K. C. U. Mugnol, F. M. Braga, I. L. S. Tersariol, S. S. Smaili and I. L. Nantes (2007) Protective role of mitochondrial unsaturated lipids on the preservation of the apoptotic ability of cytochrome c exposed to singlet oxygen. J. Biol. Chem. 282, 25577-25587.

47. Fruhwirth, T., G. Fritz, N. Freiberger and O. Glatter (2004) Structure and order in lamellar phases determined by small-angle scattering. J. Appl. Crystallogr. 37, 703-710.

48. Fernandez, R. M., K. A. Riske, L. Q. Amaral, R. Itri and M. T. Lamy (2008) Influence of salt on the structure of DMPG studied by SAXS and optical microscopy. Biochim. Biophys. Acta 1778, 907-916.

49. Ortore, M. G., F. Spinozzi, P. Mariani, A. Paciaroni, L. R. S. Barbosa, H. Amenitsch, M. Steinhart, J. Ollivier and D. Russo (2009) Combining structure and dynamics: non-denaturing highpressure effect on lysozyme in solution. J. R. Soc. Interface 6, S619-S634.

50. Homem-de-Mello, P., B. Mennucci, J. Tomasi and A. B. F. da Silva (2005) The effects of solvation in the theoretical spectra of cationic dyes. Theoret. Chem. Acc. 113, 274-280.

51. Wilkinson, F., W. P. Helman and A. B. Ross (1995) Rate constants for the decay and reactions of the lowest electronically excited singlet-state of molecular-oxygen in solution - an expanded and revised compilation. J. Phys. Chem. Ref. Data 24, 663-1021.

52. Adachi, K., T. Mita, T. Yamate, S. Yamazaki, H. Takechi and $\mathrm{H}$. Watarai (2010) Controllable adsorption and ideal H-aggregation behaviors of phenothiazine dyes on the tungsten oxide nanocolloid surface. Langmuir 26, 117-125.

53. Ben-Dror, S., I. Bronshtein, A. Wiehe, B. Roder, M. O. Senge and B. Ehrenberg (2006) On the correlation between hydrophobicity, liposome binding and cellular uptake of porphyrin sensitizers. Photochem. Photobiol. 82, 695-701.

54. Ehrenberg, B., J. L. Anderson and C. S. Foote (1998) Kinetics and yield of singlet oxygen photosensitized by hypericin in organic and biological media. Photochem. Photobiol. 68, 135-140.

55. Doleiden, F. H., S. R. Fahrenholtz, A. A. Lamola and A. M. Trozzolo (1974) Reactivity of cholesterol and some fatty-acids toward singlet oxygen. Photochem. Photobiol. 20, 519-521.

56. Girotti, A. W. (2001) Photosensitized oxidation of membrane lipids: reaction pathways, cytotoxic effects, and cytoprotective mechanisms. J. Photochem. Photobiol. B, Biol. 63, 103-113.

57. Domingues, M. M., M. L. Bianconi, L. R. S. Barbosa, P. S. Santiago, M. Tabak, M. A. R. B. Castanho, R. Itri and N. C. Santos (2013) rBPI21 interacts with negative membranes endothermically promoting the formation of rigid multilamellar structures. Biochim. Biophys. Acta 1828, 2419-2427.

58. Caetano, W., P. S. Haddad, R. Itri, D. Severino, V. C. Vieira, M. S. Baptista, A. P. Schroder and C. M. Marques (2007) Photo-induced destruction of giant vesicles in methylene blue solutions. Langmuir 23, 1307-1314.

59. Uchoa, A. F., K. T. de Oliveira, M. S. Baptista, A. J. Bortoluzzi, Y. Iamamoto and O. A. Serra (2011) Chlorin photosensitizers sterically designed to prevent self-aggregation. J. Org. Chem. 76, 8824-8832.

60. Yazdani, O., M. Irandoust, J. B. Ghasemi and S. Hooshmand (2012) Thermodynamic study of the dimerization equilibrium of methylene blue, methylene green and thiazole orange at various surfactant concentrations and different ionic strengths and in mixed solvents by spectral titration and chemometric analysis. Dyes Pigm. 92, 10311041.

61. Khandelia, H. and O. G. Mouritsen (2009) Lipid gymnastics: evidence of complete acyl chain reversal in oxidized phospholipids from molecular simulations. Biophys. J. 96, 2734-2743. 
62. Riske, K. A., T. P. Sudbrack, N. L. Archilha, A. F. Uchoa, A. P. Schroder, C. M. Marques, M. S. Baptista and R. Itri (2009) Giant vesicles under oxidative stress induced by a membrane-anchored photosensitizer. Biophys. J. 97, 1362-1370.

63. Mason, R. P., M. F. Walter and P. E. Mason (1997) Effect of oxidative stress on membrane structure: small-angle $\mathrm{x}$-ray diffraction analysis. Free Radical Biol. Med. 23, 419-425.
64. Kuimova, M. K., G. Yahioglu and P. R. Ogilby (2009) Singlet oxygen in a cell: spatially dependent lifetimes and quenching rate constants. J. Am. Chem. Soc. 131, 332-340.

65. Wainwright, M. and R. M. Giddens (2003) Phenothiazinium photosensitisers: choices in synthesis and application. Dyes Pigm. 57, $245-257$. 


\title{
Structural Characterization of Heparin-induced Glyceraldehyde-3-phosphate Dehydrogenase Protofibrils Preventing $\alpha$-Synuclein Oligomeric Species Toxicity ${ }^{*}$
}

\author{
Received for publication, December 23, 2013, and in revised form, March 12, 2014 Published, JBC Papers in Press, March 26, 2014, DOI 10.1074/jbc.M113.544288
}

César L. Ávila ${ }^{\ddagger 1}$, Clarisa M. Torres-Bugeau ${ }^{\ddagger}$, Leandro R. S. Barbosa ${ }^{\S 2}$, Elisa Morandé Sales ${ }^{\S}$, Mohand O. Ouidja ${ }^{\uparrow \|}$, Sergio B. Socías", M. Soledad Celej**, Rita Raisman-Vozari", Dulce Papy-Garcia", Rosangela Itri ${ }^{\$ 2}$, and Rosana N. Chehín ${ }^{\ddagger 3}$

From the ${ }^{\ddagger}$ Instituto Superior de Investigaciones Biológicas (INSIBIO), CONICET-UNT, and Instituto de Química Biológica "Dr. Bernabé Bloj," FBQF-UNT, Chacabuco 461, T4000ILI Tucumán, Argentina, the \$ Instituto de Física da Universidade de São Paulo, Rua do Matão, Travessa R, 187, São Paulo, Brazil, "INSERM U1127, CNRS UMR 7225, Institut de Cerveau et de la Moelle Epinière, Paris, France, the "Laboratoire Croissance, Réparation et Régénération Tissulaires, CNRS EAC 7149, Université Paris Est Créteil, Université Paris Est, F-94000, Créteil, France, and the **Departamento de Química Biológica, Centro de Investigaciones en Química Biológica de Córdoba, CONICET, Facultad de Ciencias Químicas, Universidad Nacional de Córdoba, Haya de la Torre y Medina Allende, Ciudad Universitaria, X5000HUA Córdoba, Argentina

Background: Although glycosaminoglycan-induced GAPDH prefibrillar species accelerates $\alpha$-synuclein aggregation, its role in toxicity remains unclear.

Results: The toxic effect exerted by $\alpha$-synuclein oligomers on cell culture was abolished by GAPDH protofibril, which was identified and structurally characterized.

Conclusion: GAPDH protofibrils can efficiently sequester $\alpha$-synuclein toxic oligomers.

Significance: GAPDH protofibrils may play an important role in neuronal proteostasis and could open a novel therapeutic strategy for synucleinopathies.

Glyceraldehyde-3-phosphate dehydrogenase (GAPDH) is a multifunctional enzyme that has been associated with neurodegenerative diseases. GAPDH colocalizes with $\alpha$-synuclein in amyloid aggregates in post-mortem tissue of patients with sporadic Parkinson disease and promotes the formation of Lewy body-like inclusions in cell culture. In a previous work, we showed that glycosaminoglycan-induced GAPDH prefibrillar species accelerate the conversion of $\alpha$-synuclein to fibrils. However, it remains to be determined whether the interplay among glycosaminoglycans, GAPDH, and $\alpha$-synuclein has a role in pathological states. Here, we demonstrate that the toxic effect exerted by $\alpha$-synuclein oligomers in dopaminergic cell culture is abolished in the presence of GAPDH prefibrillar species. Structural analysis of prefibrillar GAPDH performed by small angle $\mathrm{x}$-ray scattering showed a particle compatible with a protofibril. This protofibril is shaped as a cylinder $22 \mathrm{~nm}$ long and a crosssection diameter of $12 \mathrm{~nm}$. Using biocomputational techniques, we obtained the first all-atom model of the GAPDH protofibril, which was validated by cross-linking coupled to mass spectrometry experiments. Because GAPDH can be secreted outside the cell where glycosaminoglycans are present, it seems plausible that GAPDH protofibrils could be assembled in the extracellu-

\footnotetext{
* This work was supported in part by grants from Florencio Fiorini Foundation; Ecos-Sud Grant A12S02, and CIUNT Grant D439-1.

' Supported by ANPCyT Grant PICT-2011-0761.

${ }^{2}$ Supported by research fellowships from Conselho Nacional de Pesquisa e Desenvolvimento.

${ }^{3}$ To whom correspondence should be addressed: Instituto Superior de Investigaciones Biológicas, CCT-Tucumán and Instituto de Química Biológica Dr. Bernabé Bloj (CONICET-UNT) Chacabuco 461 (T4000ILI) Tucumán, Argentina. Tel.: 54-0381-4248921; Fax: 54-0381-4248921; E-mail: rosana@ fbqf.unt.edu.ar.
}

lar space kidnapping $\alpha$-synuclein toxic oligomers. Thus, the role of GAPDH protofibrils in neuronal proteostasis must be considered. The data reported here could open alternative ways in the development of therapeutic strategies against synucleinopathies like Parkinson disease.

Neurodegenerative diseases like prion, Alzheimer, Huntington, and Parkinson diseases are classically characterized by brain proteinaceous aggregates. Lewy bodies and Lewy neurites, the neuropathological hallmarks of Parkinson disease and several neurological diseases, are mainly constituted by intracellular filamentous aggregates of the protein $\alpha$-synuclein $(\alpha-\mathrm{SN})^{4}(1)$. In addition, recent studies have demonstrated the presence of misfolded or aggregated extracellular $\alpha-\mathrm{SN}$, suggesting that the pathogenic action of this protein might involve the transfer of $\alpha$-SN from one cell to another through the extracellular space, with deadly consequences to the recipient cell (2-6). In vitro studies revealed that $\alpha$-SN amyloid aggregation is a nucleation-dependent event that occurs in a process ranging from monomer via oligomers to fibrils $(7,8)$. Several studies conducted in vitro and in vivo showed that oligomeric $\alpha$-SN intermediates are more toxic to cells than the monomeric or fibrillar forms of the protein $(8-11)$. One of the main pathways of $\alpha$-SN oligomer-induced pathogenicity is related to the impartment of biomembranes (12).

\footnotetext{
${ }^{4}$ The abbreviations used are: $\alpha$-SN, $\alpha$-synuclein; GAG, glycosaminoglycan; SAXS, small angle $x$-ray scattering; SUV, small unilamellar vesicle; PICUP, photo-induced cross-linking of unmodified protein; MTT, 3-(4,5-dimethylthiazol-2-yl)-2,5-diphenyltetrazolium bromide; ThT, thioflavin T; SAP, spatial aggregation propensity.
} 


\section{Characterization of Neuroprotective GAPDH Protofibril}

Glyceraldehyde-3-phosphate dehydrogenase (GAPDH) and glycosaminoglycans (GAGs) have been found to be associated with $\alpha$-SN amyloid aggregates in Parkinson disease $(11,13,14)$. On the one hand, GAPDH colocalizes with $\alpha$-SN in amyloid aggregates in post-mortem tissue of patients with sporadic Parkinson disease and promotes the formation of Lewy body-like inclusions in cell culture. GAPDH is a homotetrameric enzyme largely expressed in cells and well known for its central role in energy production. However, recent data suggest that GADPH also possesses highly diverse nonglycolitic functions in the intra- or extracellular space (15) and has also been related to neurodegenerative diseases (16-22). Moreover, genomic analysis suggests that GAPDH has a protective effect on late-onset Alzheimer disease (23). On the other hand, GAGs are present in most, if not all, types of amyloids inside and outside of the cells $(24,25)$. In vitro, GAGs have proved to affect protein aggregation kinetics (26). We recently reported that sulfated GAGs, like heparin and heparan sulfates, are able to trigger GAPDH amyloid aggregation under $\mathrm{pH}$ and temperature physiological conditions (27). The heparin-induced GAPDH species formed during the early stages of the aggregation process $\left(\mathrm{HI}-\mathrm{GAPDH}_{\mathrm{ESS}}\right.$ ) are able to accelerate $\alpha$-SN aggregation with a remarkable efficiency (27). In this study, we show for the first time that the interaction among GAGs, GAPDH, and $\alpha$-SN exerts a protective role on dopaminergic cell survival. We have also performed a structural characterization of the HI-GAPDH $\mathrm{ESS}_{\text {by }}$ using small angle $\mathrm{x}$-ray scattering (SAXS) combined with mass spectrometry, protein docking, and molecular dynamics simulations. Among the HI-GAPDH $\mathrm{ESS}_{\mathrm{ES}}$ mixture, we were able to identify a native-like dimer as well as a protofibrillar species $22 \mathrm{~nm}$ long with a diameter of $12 \mathrm{~nm}$. The experimental results strongly suggest that the protofibrils are the scavengers of the $\alpha$-SN toxic oligomeric species. A protofibril all-atom model consistent with experimental constraints is herein presented. Upon secretion in the extracellular space, GAPDH might interact with GAGs leading to the formation of GAPDH protofibrils, which could improve neuron survival by sequestering toxic species of $\alpha$-SN. In this context, our results could pave the way for a novel therapeutic strategy on neurodegenerative diseases.

\section{EXPERIMENTAL PROCEDURES}

Preparation of Oligomer-rich $\alpha$-SN Samples-Expression and purification of recombinant human $\alpha$-SN were performed as described previously (28). The purity of the protein was assessed by SDS-PAGE. Monomeric $\alpha$-SN stock solutions were prepared in $20 \mathrm{~mm}$ HEPES, $\mathrm{pH}$ 7.4. Prior to measurements, protein solutions were filtered and centrifuged for $30 \mathrm{~min}$ at $12,000 \times g$. The protein concentration was determined by the measurement of absorbance at $275 \mathrm{~nm}$ using extinction coefficient $\epsilon_{275}=5600 \mathrm{~cm}^{-1} \mathrm{M}^{-1}$. The aggregation protocol was adapted from previous studies $(29,30)$. Monomeric $\alpha$-SN solutions $(140 \mu \mathrm{M})$ in $20 \mathrm{~mm}$ HEPES, pH 7.4, were incubated in a Thermomixer ${ }^{\circledR}$ comfort (Eppendorf) at $37^{\circ} \mathrm{C}$ and $700 \mathrm{rpm}$. Aggregation was monitored with an ISS (Champaign, IL) PC1 spectrofluorometer using a thioflavin $\mathrm{T}$ (ThT) fluorescence assay on aliquots withdrawn from the incubation mixture at different times, according to LeVine (28). Oligomer-containing samples $\left(\alpha-\mathrm{SN}_{\text {oli }}\right)$ were harvested at $16 \mathrm{~h}$ of incubation, before the onset of the exponential fibril-growth phase.

Transmission Electron Microscopy-Aggregated $\alpha$-SN (10 $\mu \mathrm{l})$ was adsorbed onto Formvar-coated carbon grids (200 mesh), washed with Milli-Q water, and stained with 2\% (w/v) uranyl acetate. The samples were imaged in a JEM-1200 Ex (Jeol) transmission electron microscope equipped with a GATAN camera, model 785.

Infrared Spectroscopy Measurements-Samples at $4 \mathrm{mg} / \mathrm{ml}$ $20 \mathrm{~mm}$ pD $7 \mathrm{D}_{2} \mathrm{O} / \mathrm{HEPES}$ buffer of $\alpha$-SN were collected after $16 \mathrm{~h}$ of orbital incubation at $37{ }^{\circ} \mathrm{C}$. Because monomeric $\alpha$-SN was higher than the oligomeric species after $16 \mathrm{~h}$ of incubation, we partially separated it from the monomer using an Amicon Ultra-0.5 100-kDa cutoff filter and assembled it in a thermostatted cell between two $\mathrm{CaF}_{2}$ windows with a path length of 50 $\mathrm{nm}$. The spectra were recorded in a Nicolet 5700 spectrometer equipped with a DTGS detector (Thermo Nicolet, Madison, WI) as described previously (31). The $\mathrm{D}_{2} \mathrm{O}$ contribution in the amide I' region was eliminated by subtracting the buffer spectra from that of the solution at the same temperature to obtain a flat baseline between 2000 and $1700 \mathrm{~cm}^{-1}$. Fourier self- deconvolution and determination of band position of the original amide I' band were performed as described (31).

Human Neuroblastoma Cell Culture-SH-SY5Y cells were grown in DMEM supplemented with $10 \%$ fetal bovine serum (FBS) and $1 \%$ penicillin/streptavidin, at $37{ }^{\circ} \mathrm{C}$ and $5 \% \mathrm{CO}_{2}$. For the assay, cells were seeded in 96-well plates at 15,000 cells/well and maintained in $100 \mu \mathrm{l}$ of DMEM supplemented with $10 \%$ FBS and $1 \%$ penicillin/streptavidin for $24 \mathrm{~h}$ at $37^{\circ} \mathrm{C}$ and treated as follows: control untreated cells received $25 \mu$ l of HEPES buffer (20 mM, pH 7.4); heparin-treated cells received $25 \mu \mathrm{l}$ of a $75 \mu \mathrm{g} / \mathrm{ml}$ heparin solution; GAPDH-treated cells received $25 \mu \mathrm{l}$ of a GAPDH (50 $\mu \mathrm{M}$ in HEPES) solution preincubated for $24 \mathrm{~h}$ at $37{ }^{\circ} \mathrm{C}$; HI-GAPDH $\mathrm{ESS}$-treated cells received $25 \mu \mathrm{l}$ of a GAPDH $(50 \mu \mathrm{M})$ solution preincubated with $75 \mu \mathrm{g} / \mathrm{ml}$ heparin for $1 \mathrm{~h}$ and $\alpha-\mathrm{SN}_{\text {oli }}$-treated cells received $25 \mu \mathrm{l}$ of an $\alpha$-SN (140 $\mu \mathrm{M})$ solution preincubated for $16 \mathrm{~h}$ at $37^{\circ} \mathrm{C} ; \mathrm{GAPDH}+$ $\alpha-\mathrm{SN}_{\text {oli }}$-treated cells received $25 \mu \mathrm{l}$ of a GAPDH $(50 \mu \mathrm{M})+$ $\alpha-\mathrm{SN}_{\text {oli }}(140 \mu \mathrm{M})$; and HI-GAPDH $\mathrm{ESS}+\alpha-\mathrm{SN}_{\text {oli }}$-treated cells received $25 \mu \mathrm{l}$ of a HI-GAPDH $\mathrm{ESS}(50 \mu \mathrm{M})+\alpha-\mathrm{SN}_{\text {oli }}(140 \mu \mathrm{M})$ mixture. Mixtures containing GAPDH and $\alpha$-SN were preincubated for $1 \mathrm{~h}$ at $37^{\circ} \mathrm{C}$ under orbital agitation before addition to the cells. $\mathrm{H}_{2} \mathrm{O}_{2}$ (75 $\mu \mathrm{M}$ final in medium) was used for cell death control. Cell viability was determined using the colorimetric MTT metabolic activity assay (32). All experiments were performed in sextuplicate, and the relative cell viability (\%) was expressed as a percentage relative to the untreated control cells.

Calcein Release Assay-The lipid mixture used for these experiments was extracted from brain membranes of Wistar white rats by Folch method (33). Rats were provided by the "Bioterio" Instituto de Química Biológica (Facultad de Bioquímica, Química y Farmacia, UNT, Tucumán, Argentina). The rats were obtained by exocria and maintained under controlled temperature and humidity under a 12-h light/dark cycle. The animals were maintained and treated in accordance with the criteria established in the "Guide for the Care and Use of Laboratory Animals," published by the Institute of Laboratory Animal and National Research (1999). After extraction, 


\section{Characterization of Neuroprotective GAPDH Protofibril}

lipids were stored in chloroform/methanol (2:1, v/v). For the preparation of large multilamellar vesicles, lipids were dried under nitrogen onto the wall of a Corex glass tube, placed in a vacuum oven to completely remove any remaining solvent, and then rehydrated in $25 \mathrm{~mm}$ Tris, $50 \mathrm{~mm}$ calcein, pH 7.4 buffer. To obtain small unilamellar vesicles (SUVs), multilamellar vesicles were sonicated with probe-type sonifier under nitrogen and controlled temperature. To remove titanium debris, the suspension was centrifuged for $15 \mathrm{~min}$ at $1100 \times g$ (34). To separate calcein-loaded SUV from free dye, a Sephadex G-75 gel filtration medium (Pharmacia Biotech) was used. During incubation, changes in the fluorescence intensity of the different mixtures were monitored at $\lambda_{\mathrm{exc}}=490 \mathrm{~nm}$ and $\lambda_{\mathrm{em}}=510 \mathrm{~nm}$ (35) in an ISS (Champaign, IL) PC1 spectrofluorometer. GAPDH $(50 \mu \mathrm{M})$ solution preincubated with $75 \mu \mathrm{g} / \mathrm{ml}$ heparin for $1 \mathrm{~h}$ and $\alpha-\mathrm{SN}_{\text {oli }}$-treated SUVs received $25 \mu \mathrm{l}$ of an $\alpha$-SN (140 $\mu \mathrm{M})$ solution preincubated for $16 \mathrm{~h}$ at $37^{\circ} \mathrm{C}$; GAPDH + $\alpha-\mathrm{SN}_{\text {oli }}$-treated SUVs received $25 \mu \mathrm{l}$ of a GAPDH $(50 \mu \mathrm{M})+$ $\alpha$-SN oli $(140 \mu \mathrm{M}) ; \mathrm{HI}-\mathrm{GAPDH}_{\mathrm{ESS}}+\alpha$-SN $_{\text {oli }}$-treated SUVs received $25 \mu \mathrm{l}$ of an $\mathrm{HI}-\mathrm{GAPDH}_{\mathrm{ESS}}(50 \mu \mathrm{M})+\alpha-\mathrm{SN}_{\text {oli }}(140 \mu \mathrm{M})$. Mixtures containing GAPDH and $\alpha$-SN were preincubated for $1 \mathrm{~h}$ at $37^{\circ} \mathrm{C}$ under orbital agitation before addition to $50 \mu \mathrm{M}$ lipid vesicles. Total dye release was completed by the addition of 0.1 volume $\%$ Triton $X-100$. The percentage of probe release was calculated as shown in Equation 1,

$$
\% \text { dye release }=\left(I_{F}-I_{B}\right) /\left(I_{T}-I_{B}\right) \times 100
$$

where $I_{F}, I_{T}$, and $I_{B}$ are the fluorescence intensity of the dye released by the protein, total dye released, and control blank.

Small Angle X-ray Scattering Data-The scattering intensity of a noninteracting polydisperse system, which can be regarded as a mixture with $p$ components, can be written as shown in Equation 2 (36),

$$
I(q)=k n_{\text {prot }} \sum_{i=1}^{n} \frac{w_{i}}{N_{\text {agg }}^{i}} P_{i}(q)
$$

where $k$ is a constant related to the experimental setup and should be the same for different SAXS curves collected within the same beamline setup; $N_{\text {agg }}^{i}$ is the aggregation number of the $i$-th species, for instance, the values for the tetramer, dimer, and cylinder are 4, 2, and $N_{\text {agg }}$, respectively; $P_{i}(q)$ is the form factor of the $i$-th species, and $w_{i}$ is weight in this model. It is important to consider that $n_{\text {prot }} \mathrm{w}_{i}$ is the concentration of the $i$-th species, or even the total amount of protein composed in each species.

The scattering curves of GAPDH in the presence of heparin were analyzed as a linear combination of three different species on solution (tetramers, dimers and an effective cylinder) in such a way that we get Equation 3,

$$
I(q) \approx k n_{\text {prot }}\left(\frac{W_{\text {tetr }}}{4} P_{\text {tetr }}(q)+\frac{W_{\text {dim }}}{2} P_{\text {dim }}(q)+\frac{W_{\text {cyl }}}{N_{\text {agg }}} P_{\text {cyl }}(q)\right)
$$

where $w_{\text {tetr }}, w_{\text {dim }}$, and $w_{\text {cyl }}$ are the weight of the tetramer, dimer, and an effective cylinder, respectively, and they respond to the following equation: $w_{\text {tetr }}+w_{\text {dim }}+w_{\text {cyl }}=1$. All SAXS data analysis was performed with GENFIT software $(37,38)$.
It should be remarked here that the choice of such a set of species in solution was based on the previous analysis of the distance distribution function $p(r)$ (30), which is a model-independent procedure. The previous $p(r)$ analysis thus showed that a rod-like protein aggregate evolved in the solution, coexisting with a native tetramer, reaching a maximum dimension of 25 $\mathrm{nm}$ with a cross-section radius of $\sim 6 \mathrm{~nm}$ up to $180 \mathrm{~min}$ of GAPDH-heparin incubation (30). However, as we mention below, the modeling fails to reproduce the experimental data at a high $q$ range if smaller species as dimers are not included in the data analysis. The presence of monomers, instead of dimers in solution, was also probed. However, to get a good fitting to the experimental data, the modeled cylinders resulted in maximum dimensions on the order of $50 \mathrm{~nm}$, which is not consistent with $p(r)$ analysis.

Therefore, concerning the SAXS models employed here, both the tetramer and the dimer were calculated using the protein crystallographic structure (Protein Data Bank code 1J0X), through SASMOL methodology (37). Such a methodology assumes that the structures of the protein in the crystal and in solution are the same.

Regarding the form factor of an effective cylinder, it can be described as shown in Equation 4 (39),

$$
I_{c y l}(q)=n_{c y l}\left(2 \pi R^{2} L \Delta \rho\right)^{2} \int_{0}^{1}\left(\frac{J_{1}\left(q R \sqrt{1-x^{2}}\right) \sin \left(\frac{q x L}{2}\right)}{q R \sqrt{1-x^{2}} \frac{q x L}{2}}\right) d x
$$

where $R$ is the cylinder radius; $L$ its length; $\Delta \rho_{\text {cyl }}=\left(\rho_{\text {cyl }}-\rho_{\text {sol }}\right)$ is the electron density contrast between the cylinder $\left(\rho_{\text {cyl }}\right)$ and the solvent $\left(\rho_{\text {sol }}\right)$ and $n_{\text {cyl }}$ the cylinder numeric density, which can be written as a function of the total protein concentration as: $n_{\text {cyl }}=n_{\text {prot }} w_{\text {cyl }}$, with $n_{\text {prot }}$ the total protein concentration, and $w_{\text {cyl }}$ the weight of the cylinder in the SAXS curve.

Furthermore, it is possible to rewrite some of the cylinder's structural parameters as a function of others as shown in Equation 5,

$$
V_{\text {cyl }}=\pi R^{2} L=\frac{N_{\mathrm{agg}} V_{\mathrm{mon}}}{\phi_{\text {cyl }}}
$$

where $V_{\text {cyl }}$ is the cylinder volume, and $N_{\text {agg }}$ is the monomer-like aggregation number inside the cylinder. The volume of the GAPDH monomer is known from its crystallographic structure $\left(\nu_{\text {mon }}=44,936 \AA^{3}\right) \cdot \varphi_{\text {cyl }}$ is the volume fraction of GAPDH inside the cylinder, i.e. $\varphi_{\text {cyl }}=N_{\text {agg }} \nu / V_{\text {cyl }}$. Finally, both $L$ and $\rho_{\text {cyl }}$ can be now re-written as a function of $\varphi_{\text {cyl }}$ as shown in Equations 6 and 7 ,

$$
L=\frac{N_{\mathrm{agg}} v_{\mathrm{mon}}}{\pi R^{2} \phi_{\mathrm{cyl}}}
$$

and

$$
\rho_{\text {cyl }}=\phi_{\text {cyl }} \rho_{\text {prot }}+\left(1-\phi_{\text {cyl }}\right) \rho_{\text {sol }}
$$

$\rho_{\text {prot }}$ is the theoretical electron density of the protein, calculated from its sequence $\left(\rho_{\text {prot }}=0.4235 \mathrm{e} / \AA^{3}\right)$, and $\rho_{\text {sol }}$ is the electron density of the solvent $\left(=0.333 \mathrm{e} / \AA^{3}\right)$. After such rearrangement, the cylinder can be modeled using $R, N_{\text {agg, }}$ and $\varphi_{\text {cyl }}$ as 


\section{Characterization of Neuroprotective GAPDH Protofibril}

fitting parameters and all the other variables concerning this model can be written as a function of these three variables.

Applying such methodology, the final set of fitting parameters are then $R, N_{\text {agg }}, \varphi_{\text {cyl }}$, and $w_{\text {tetr }}, w_{\text {dim }}$, and $w_{\text {cyl }}$ besides the experimental constant $k$.

Photoinduced Cross-linking of GAPDH in the Presence of Heparin-The mixture of GAPDH/heparin at a final concentration of $1 \mathrm{mg} / \mathrm{ml}, 0.5 \mathrm{mg} / \mathrm{ml}$ was preincubated at $37^{\circ} \mathrm{C}$ under agitation for $0,5,30,60,90$, and $120 \mathrm{~min}$. For each mixture obtained at different time intervals, the photoreaction was carried out in a $10 \times 10-\mathrm{mm}$ quartz fluorescence cuvette with 1000 $\mu \mathrm{l}$, following a similar procedure to the one previously described by Fancy et al. $(40,41)$. Concentration of the photosensitizer tris(bipyridine)ruthenium(II) dichloride was $10 \mu \mathrm{M}$, and a 20-fold molar excess of the electron acceptor ammonium persulfate was present with a time exposure to light of $1 \mathrm{~min}$ The samples were placed in a cuvette holder with a magnetic stirrer and irradiated with a Superlite SUV-DC illuminator (Lumatec, Germany) equipped with a 200-watt DC super pressure short arc mercury lamp. After the irradiation, 20- $\mu$ l aliquots of the samples were diluted with $5 \mu$ l of SDS-loading buffer containing $\beta$-mercaptoethanol to quench the radical reaction. The samples were boiled for $10 \mathrm{~min}$ and then $20 \mu \mathrm{l}$ of each sample were loaded per lane on $10 \%$ SDS acrylamide gels. Electrophoresis was carried out in a Bio-Rad Mini PROTEAN ${ }^{\circledR}$ system in slab gels using the buffer and fixing described by Weber and Osborn (42). The gel was stained with Coomassie Blue staining method. The protein molecular weight marker was Precision Plus Protein ${ }^{\mathrm{TM}}$ Standards. Conversely, 200- $\mu \mathrm{l}$ aliquots of the samples were placed in ISS (Champaign, IL) PC1 spectrofluorometer where the emission spectrum of tyrosine and dityrosil was made. Emission spectra were registered setting $\lambda_{\text {exc }}$ at 275 and $320 \mathrm{~nm}$ for selective excitation of Tyr or di-Tyr, respectively.

Trypsin Fingerprinting and Mass Spectrometric AnalysisFor determination of photoinduced cross-linking modifications, trypsin fingerprinting was applied. Aliquots of photoinduced cross-linked tetrameric and aggregated GAPDH samples were separated by SDS-PAGE analysis as described above, treated with dithiothreitol/iodoacetamide, and digested in-gel using $20 \mu \mathrm{l}$ of trypsin solution $(25 \mathrm{ng} / \mu \mathrm{l})$. Extracts from each sample were desalted using $\mathrm{C} 18$ resin accommodated in a tip ( $\mu$ Zip Tip Millipore). The peptides were extracted from the resin with an $\alpha$-cyanohydroxycinnamic acid solution used as matrix. The masses of the digestion products were analyzed using reflex mode MALDI-TOF mass spectrometry (ABI Mass Spectrometer 4800 plus MALDI-TOF-TOF). The identity of the signals was determined using GPMAW 9.2.

Computational Modeling of the Protofibril-Protein-protein docking models were generated using SymmDock (43). The crystallographic structure of the asymmetric unit for rabbit muscle GAPDH (44) deposited in RCSB (Protein Data Bank code 1J0X, chains $\mathrm{O}$ and $\mathrm{P}$ ) was used as the building block. Complex models were predicted using 2-18-fold cyclic, dihedral, cubic, and helical symmetry by geometric docking algorithms. To predict the complex, we have applied the SymmDock algorithm twice in a two-step fashion. First, from the dimer we predicted a hexamer with $\mathrm{C}_{3}$ rotational symmetry, which in turn served as the input to build the 36-mer structure. The top 100 solutions of each run were analyzed, and candidate models failing to match the geometrical features derived from SAXS studies were discarded.

To further relax the structure of the protofibril model, molecular dynamic simulations were performed using a multiscale approach. At first, coarse grained simulations of the system were performed using the MARTINI force field (45) and its extension to proteins (46) as implemented in the GROMACS package. Elastic network constraints were also applied to maintain the internal structure of individual subunits (47). The elastic bond strength and the upper cutoff were set to $500 \mathrm{kcal} / \mathrm{mol}$ and $0.8 \mathrm{~nm}$, respectively. Based on a comparison with all atom simulations, these were the parameters that better conserve the native structure while preserving realistic dynamics of the system. It should be noted that constraints introduced by the elastic network apply only to the tertiary structure, whereas the quaternary structure is free to change. The systems were simulated for $4 \mu \mathrm{s}$ (16 $\mu$ s effective time) coupled to Nose-Hoover thermostat and Parrinello-Rahman barostat. In a second stage, all-atom detail was included in the model by using the reverse transformation protocol described by Rzepiela et al. (48).

Contact Maps Calculation-Contact between a given pair of residues at the interface is defined as shown in Equation 8 (49),

$$
C_{i, j}=\frac{1-\left(r_{i, j} / r_{0}\right)^{6}}{1-\left(r_{i, j} / r_{0}\right)^{10}}
$$

where $r_{0}=8.5 \AA$, and $r_{i, j}$ is the average distance between $\mathrm{C} \alpha$ atoms of residues $i$ and $j$ during the last microsecond of simulation. Through the use of this continuous function, we define a tight interaction between two residues as $C_{i, j}>0.8$.

Spatial Aggregation Propensity-Regions prone to aggregation were predicted using the algorithm called Spatial Aggregation Propensity (50) and mapped on the protein's solvent accessible surface using VMD (51). This parameter is defined in Equation 9,

$$
S A P_{i}=\sum_{\substack{\text { simulation } \\
\text { average }}}\left\{\sum_{\begin{array}{l}
\text { residues with at } \\
\text { least } \begin{array}{l}
\text { one atom } \\
\text { within } R \text { from } i
\end{array}
\end{array}}\left(\frac{S A A_{\text {sidechain atoms }} \text { within radius } R}{S A A \begin{array}{l}
\text { sidechain atoms of } \\
\text { fully exposed residue }
\end{array}} x \text { Residue Hydrophobicity }\right)\right\}
$$

where solvent-accessible areas of side chain atoms are computed at each simulation snapshot; solvent-accessible areas of fully exposed residues are calculated over a simulation of the tripeptide Ala-Xaa-Ala; and residue hydrophobicity is taken from the hydrophobicity scale of Black and Mold (52) and normalized so that glycine has hydrophobicity of zero. In this way, negative spatial aggregation propensity (SAP) values correspond to hydrophilic regions, whereas positive SAP values correspond to hydrophobic patches.

\section{RESULTS}

HI-GAPDH $H_{E S S}$ Modifies $\alpha-S N_{\text {oli }}$ Toxicity and Membrane Stability-As we have shown previously, early stage species present in the heparin-induced GAPDH amyloid aggregation pathway $\left(\mathrm{HI}-\mathrm{GAPDH}_{\mathrm{ESS}}\right.$ ) can modulate $\alpha$-SN aggregation 


\section{Characterization of Neuroprotective GAPDH Protofibril}
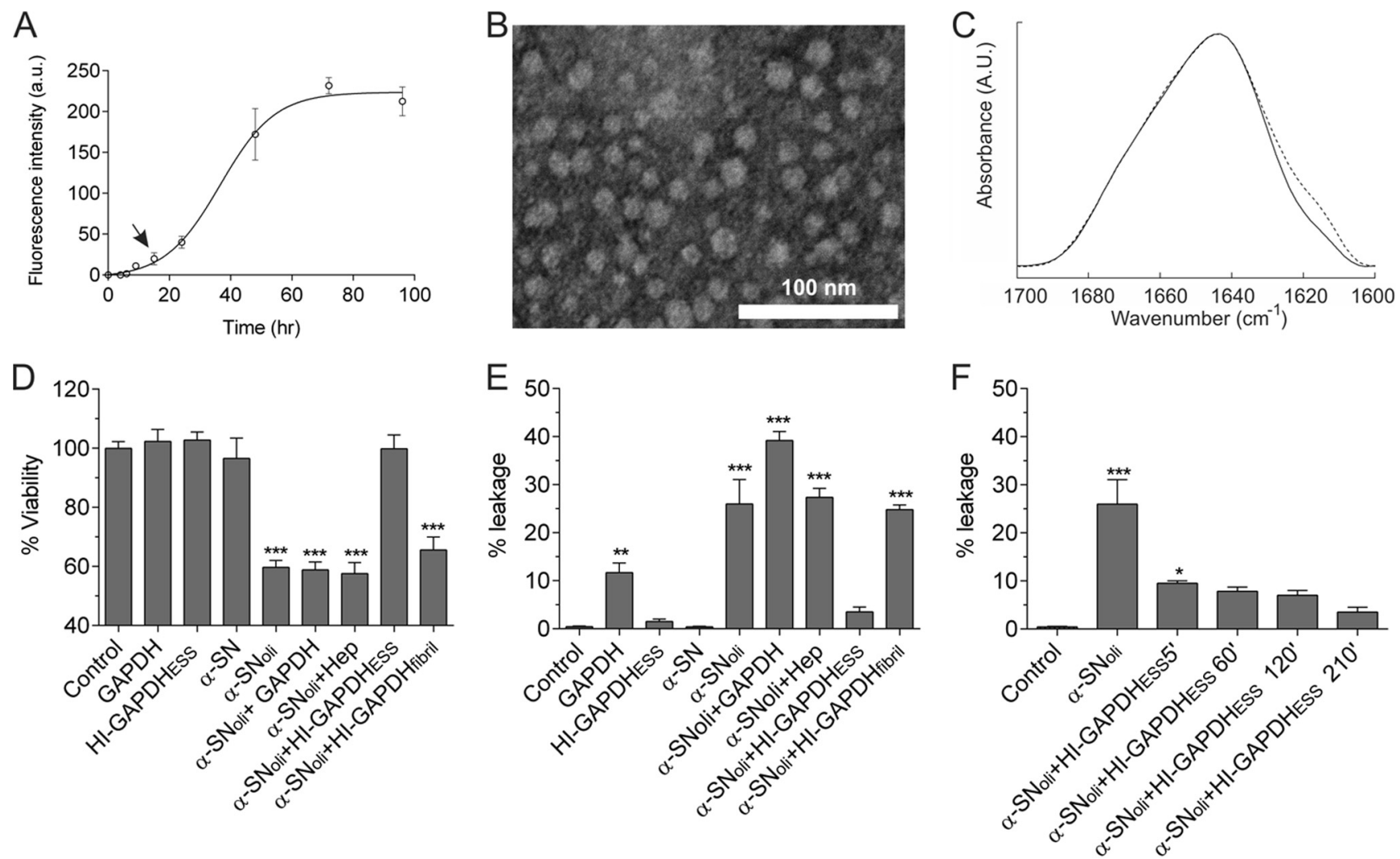

FIGURE 1. HI-GAPDH ESS $_{\text {sequesters } \alpha \text {-SN }}$ oli abolishing its deleterious effects. $A$, kinetics of $140 \mu \mathrm{M} \alpha$-SN aggregation monitored by ThT fluorescence. The arrow shows the point where $\alpha$-SN $\mathrm{SN}_{\text {oli }}$ is harvested. $B$, uranyl acetate-stained transmission electron microscopy images of $\alpha$-SN ${ }_{\text {oli. }}$ a.u., arbitrary units. $C$, FTIR

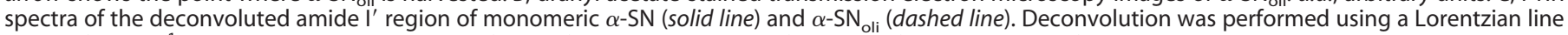
shape of $18 \mathrm{~cm}^{-1}$ and a resolution enhancement factor of 1.75.D, cell viability of SH-SY5Y after the addition of $20 \mathrm{~mm} \mathrm{HEPES,} \mathrm{pH} 7.40$ (control), or $50 \mu \mathrm{M} \mathrm{GAPDH}$.

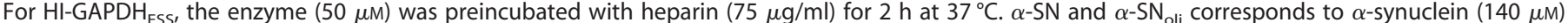
preincubated for 0 and $16 \mathrm{~h}$ at $37^{\circ} \mathrm{C}$ with orbital agitation, respectively. For $\alpha$-SN oli $+\mathrm{GAPDH}, \alpha$-SN oli was preincubated for $1 \mathrm{~h}$ at $37^{\circ} \mathrm{C}$ with GAPDH (50 $\mu \mathrm{M}$ ).

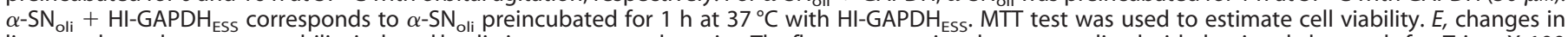
liposomal membrane permeability induced by distinct aggregated species. The fluorescence signal was normalized with the signal observed after Triton $\mathrm{X}-100$ addition, which induced complete rupture of the vesicles. $\alpha$-SN monomer was employed as leakage negative control. $\mathrm{HI}_{-\mathrm{GAPDH}} \mathrm{ESS}, \alpha-\mathrm{SN} \mathrm{oli}, \alpha-\mathrm{SN} \mathrm{oli}_{\mathrm{i}}+\mathrm{GAPDH}_{\text {, }}$ $\alpha-\mathrm{SN}_{\mathrm{oli}}$, and $\alpha-\mathrm{SN}_{\mathrm{oli}}+\mathrm{HI}-\mathrm{GAPDH} \mathrm{ESS}_{\text {sere }}$ wrepared as described above. F, effect of heparin/GAPDH incubation time on the production of species with the ability to protect membranes against content leakage induced by $\alpha-\mathrm{SN}_{\text {oli }}$ The $\alpha$-SN $\mathrm{oli}_{\text {il }}$ was preincubated with $\mathrm{HI}_{-\mathrm{GAPDH}} \mathrm{ESS}$ harvested after $5,60,120$, and 210 min of $\mathrm{GAPDH} /$ heparin mixture under orbital agitation at $37^{\circ} \mathrm{C}$. Results were evaluated by analysis of variance $(p=0.001)$, and asterisks indicate significant differences versus the control $\left({ }^{* * *}, p \leq 0.001 ;{ }^{* *}, p \leq 0.01 ;{ }^{*}, p \leq 0.05\right)$.

kinetics (27). Here, we analyze whether HI-GAPDH ESS $_{\text {can also }}$ modulate the toxicity of $\alpha$-SN $\mathrm{Sli}_{\text {on }}$ a dopaminergic cell model using SH-SY5Y cell cultures (53).

Several protocols have been devised to obtain oligomeric aggregates of $\alpha$-SN, leading to different structural and functional arrangements of the protein Here, we used a protocol adapted from Refs, 29, 30. Fig. $1 A$ shows the aggregation kinetics of $\alpha-\mathrm{SN}$ as monitored by ThT fluorescent assay. The oligomers were harvested at $16 \mathrm{~h}$, which corresponds to the lag phase. The fact that these species do not enhance ThT fluorescence suggests that they may lack the cross- $\beta$-structure characteristic of amyloid fibrils (54). In fact, the $\alpha$-SN oligomers appeared as spheroidal and polydisperse species as shown by transmission electron microscopy (Fig. 1B). The FTIR analysis of the oligomeric state revealed an increase of $\beta$-structure compared with the monomeric state as judged by the shoulder at $\sim 1618 \mathrm{~cm}^{-1}$ (Fig. 1C). Taken together, these data suggest that the $\alpha-\mathrm{SN}_{\text {oli }}$ used in this work is compatible with the soluble on-pathway oligomers described previously (55).

The addition of $\alpha-\mathrm{SN}_{\text {oli }}$ prepared as done previously to SH-SY5Y cells culture induced approximately $40 \%$ of cell death
(Fig. 1D). In contrast, preincubation of $\alpha-\mathrm{SN}_{\text {oli }}$ with HI-GAP$\mathrm{DH}_{\mathrm{ESS}}$ during $60 \mathrm{~min}$ abolished $\alpha-\mathrm{SN}_{\text {oli }}$ toxicity. This protective effect was not observed when $\alpha-\mathrm{SN}_{\text {oli }}$ was preincubated with either native GAPDH or heparin, indicating that only intermediate species formed during the heparin-induced GAPDH fibrillation can efficiently protect cells against $\alpha-\mathrm{SN}_{\text {oli }}$ toxicity. Of note, the protective effect of GAPDH was lost once the fibrillar state was reached (Fig. 1D). In addition, neither

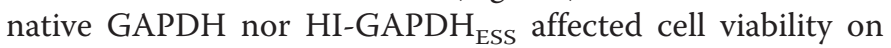
their own (Fig. 1D).

One of the proposed mechanisms by which $\alpha-\mathrm{SN}_{\text {oli }}$ exerts its toxic effect is by inducing a perturbation in the cell membrane integrity $(56-58)$. To evaluate whether HI-GAPDH ${ }_{\mathrm{ESS}}$ interferes with this mechanism, we studied the effect of preincuba-

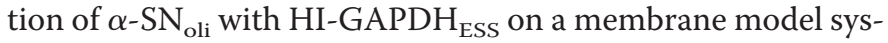
tem. To do so, we monitored the release of a fluorescent probe entrapped in rat brain lipid vesicles upon the addition of

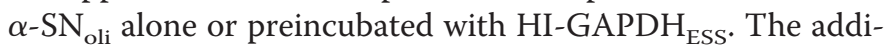
tion of $\alpha-\mathrm{SN}_{\text {oli }}$ induced the release of calcein from liposomes, confirming the ability of these species to affect membrane permeability. Noteworthy, preincubation of $\alpha-\mathrm{SN}_{\mathrm{oli}}$ with HI- 


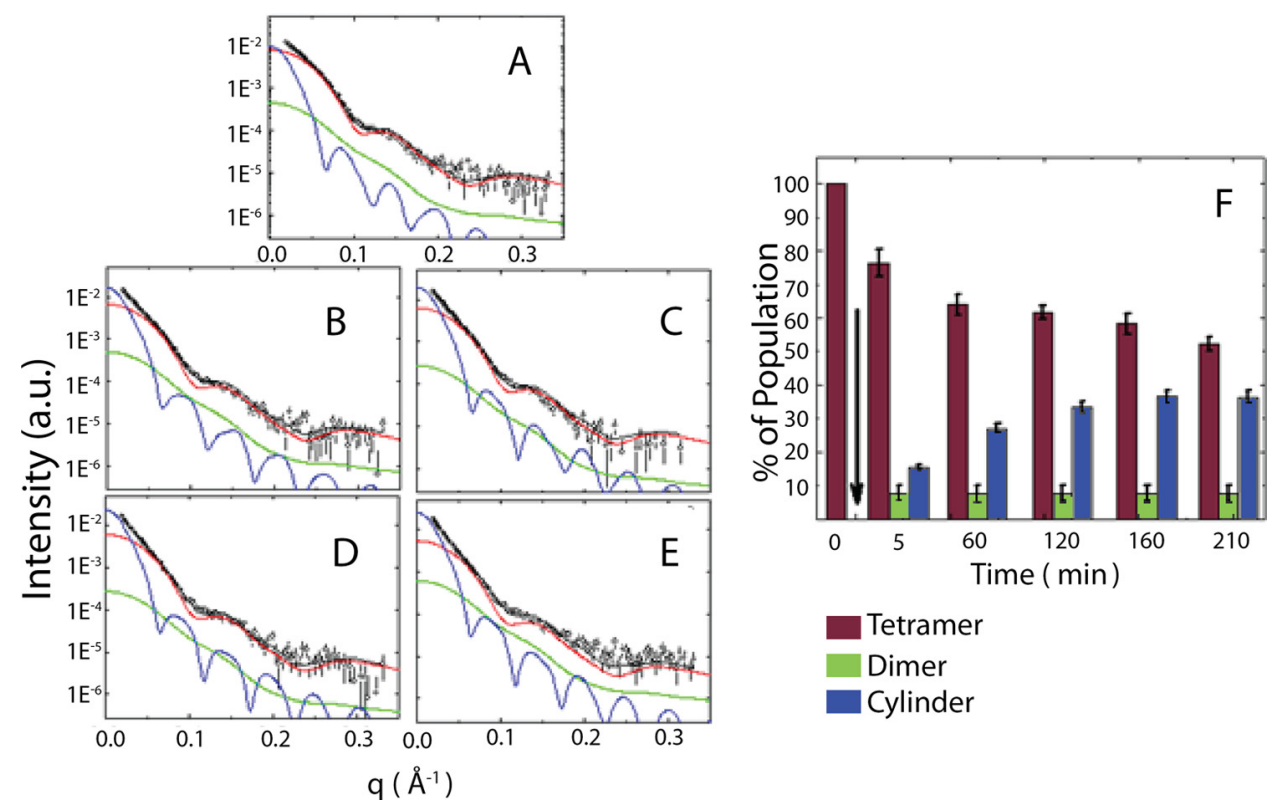

FIGURE 2. SAXS modeling of the heparin/GAPDH incubation mixture. Small angle $x$-ray scattering curves of GAPDH in the presence of heparin (open circles) at $5 \mathrm{~min}(A) ; 60 \mathrm{~min}(B) ; 120 \mathrm{~min}(C) ; 160 \mathrm{~min}(D) ;$ and $210 \mathrm{~min}(E)$. The solid black line represents the sum of three different models: GAPDH tetramer (red line), dimer (green line), and an effective cylinder (blue line). See text for details. F, relative population of GAPDH species present in the incubation mixture after the addition of heparin. The arrow indicates the moment when GAPDH and heparin were mixed. The bars represent the native-like tetramer (red vertical bar), the native-like dimer (green bar), and the protofibril (blue bar). a.u., arbitrary units.

TABLE 1

Adjustment parameters from the cylinder-like aggregate along time

The parameters used are as follows: $R$, cylinder radius; $L$, length; $\varphi_{\text {cyl }}$, the cylinder fraction volume; $N_{\text {agg }}$, aggregation number (i.e. the number of GAPDH monomers inside the cylinder); $\rho_{\text {cyl }}$, electronic density; $w_{\text {cyl }}$, weight of the cylinder in the SAXS curve. In the last two lines the average and the S.D. values are shown.

\begin{tabular}{|c|c|c|c|c|c|c|c|c|c|}
\hline Time (min) & $k$ & $w_{\text {tetr }}$ & $w_{\text {dim }}$ & $\mathbf{w}_{\text {cyl }}$ & $R$ & $L$ & $\varphi_{\text {cyl }}$ & $N_{\text {agg }}$ & $\rho_{\text {cyl }}$ \\
\hline & $10^{-5}$ & $\%$ & $\%$ & $\%$ & $\AA$ & $\AA$ & & & $e / \AA^{3}$ \\
\hline 2 & 5.08 & 76.5 & 7.96 & 15.56 & 59.6 & 200 & 0.7 & 35.0 & 0.3932 \\
\hline 52 & 5.00 & 63.99 & 9.04 & 26.97 & 57.18 & 222 & 0.68 & 35.0 & 0.3915 \\
\hline 106 & 5.00 & 61.5 & 4.94 & 33.56 & 59.07 & 210 & 0.65 & 33.0 & 0.3885 \\
\hline 160 & 5.00 & 58.35 & 4.94 & 36.7 & 59.61 & 222 & 0.66 & 36.0 & 0.3891 \\
\hline 212 & 5.12 & 52.41 & 11.11 & 36.41 & 60.02 & 219 & 0.69 & 38.0 & 0.3923 \\
\hline Average & 5.04 & & 7.6 & & 59.10 & 215 & 0.68 & 35.4 & 0.391 \\
\hline S.D. & 0.05 & & 2.4 & & 1.00 & 9 & 0.02 & 1.6 & 0.002 \\
\hline
\end{tabular}

$\mathrm{GAPDH}_{\mathrm{ESS}}$ significantly diminished such an effect (Fig. $\left.1 E\right)$. On the contrary, preincubation of $\alpha-\mathrm{SN}_{\text {oli }}$ with $\mathrm{GAPDH}$ in its native tetrameric or in its fibrillar state did not prevent calcein leakage indicating that inhibition of the $\alpha$-SN $\mathrm{Sli}_{\text {-mediated }}$ membrane permeabilization should be associated with an unidentified intermediate species among HI-GAPDH ${ }_{\mathrm{ESS}}$, which does not affect the membrane integrity on its own. It is important to note that GAPDH in its native tetrameric state induces changes in membrane permeability as described previously (59). Nevertheless, this feature is lost when the enzyme is incubated with heparin (Fig. $1 E$ ). Therefore, we demonstrate that during the early stages of aggregation, the heparin/ GAPDH incubation mixture is enriched in a particular subpopulation capable of sequestering the $\alpha-\mathrm{SN}_{\text {oli }}$.

Enrichment of HI-GAPDH $H_{E S S}$ in a Protofibrillar Species Revealed by $S A X S$-According to our previous studies,

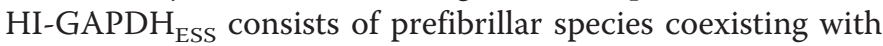
native GAPDH tetramer (27). To further inquire into the nature of the putative GAPDH species capable of recruiting $\alpha-\mathrm{SN}_{\text {oli }}$, we utilized SAXS because this technique is able to provide low resolution information on the structure of the species present in a polydisperse system as well as on their relative amounts $(36,60-63)$. In this way, we have previously shown that heparin triggers the formation of an elongated species with maximum dimension of $\sim 25 \mathrm{~nm}$ coexisting with the native tetramer through the analysis of the distance distribution function $p(r)$ (27). Here, we performed a deeper characterization of the species present during the early steps of the heparin-induced GAPDH fibrillation process. We analyzed the SAXS curves obtained by GAPDH in the absence or in the presence of heparin after 5, 60, 120, 160, and 210 min of incubation (Fig. 2). In the absence of heparin, no significant changes were evidenced in the GAPDH SAXS curves indicating the stability of the protein (27). However, in the presence of heparin, we modeled the scattering curves as a mixture composed of the native tetrameric protein (Protein Data Bank code 1J0X) and an anisometric scattering particle represented by a homogeneous cylinder. As the modeling failed to reproduce the SAXS experimental data in the high $q$ range, we evaluated the inclusion of additional smaller particles for a better fit (data not shown). Interestingly, the best fitting, performed with GENFIT software $(37,38)$, was achieved when dimers were included in the SAXS 
Characterization of Neuroprotective GAPDH Protofibril
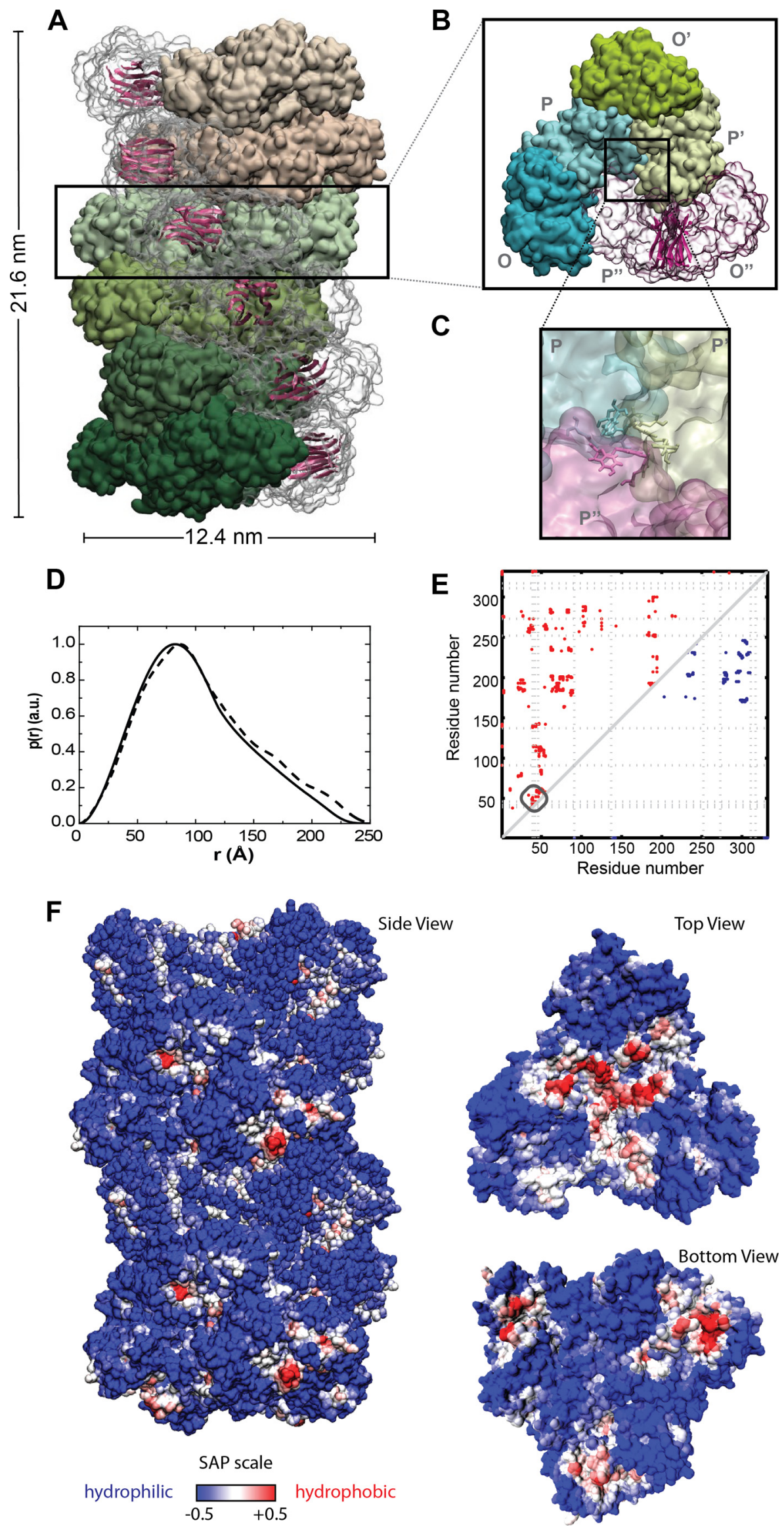


\section{Characterization of Neuroprotective GAPDH Protofibril}

data analysis, resulting in fitting parameters for the protofibril consistent with $p(r)$ analysis (30). The quality of the fittings was rather good, indicating that the modeling is compatible with the scattering data for the whole set of experiments. The fitting parameters correspond to the amount of protein in the tetrameric $\left(w_{\text {tetr }}\right)$, dimeric $\left(w_{\text {dim }}\right)$, and cylindrical $\left(w_{\text {cyl }}\right)$ forms (Table $1)$. Further parameters, the cylinder radius $(R)$, the protein fraction inside the cylinder $\left(\varphi_{\text {cyl }}\right)$, and the number of monomers composing the cylinder, which corresponds to the aggregation number $\left(N_{\text {agg }}\right)$, can also be extracted from the SAXS data analysis.

Taken together, these results suggest that in the early stages of heparin-induced fibrillation, GAPDH coexists in three different aggregation states in solution: native tetramers, nativelike dimers, and higher order aggregates with a cylindrical shape. These cylinder-like species, structurally characterized for the first time in the present results, are on average $21.5 \pm 0.9$ $\mathrm{nm}$ long with $11.8 \pm 0.2 \mathrm{~nm}$ diameter and are composed of $35 \pm$ 2 monomers (Table 1). Following the nomenclature proposed by Kodali and Wetsel (64), we will refer to these species as protofibrils.

Time-evolution of different HI-GAPDH ${ }_{\text {ESS }}$ subpopulations was obtained through the SAXS data analysis (Fig. $2 F$ ). The native tetrameric species diminished as the protofibrillar species concentration increased during the first $210 \mathrm{~min}$ of incubation of GAPDH in the presence of heparin, whereas the dimer population remained unaltered during this time interval. Noteworthy, there is a good agreement between the increment of the protofibrillar species (Fig. $2 F$ ) in the heparin/GAPDH incubation mixture and its capability to protect the membrane against $\alpha-\mathrm{SN}_{\text {oli }}$ (Fig. $1 F$ ).

All-atom Model of GAPDH Protofibrillar Species-Structural characterization of transient protofibrillar species at the atomic level is not a trivial task using classical structural techniques; therefore, we used computational modeling. Briefly, we have analyzed the most probable arrangement of GAPDH subunits within the protofibril considering the following constraints obtained from the SAXS data analysis: (i) it has a cylindrical shape, a diameter, and long axis lengths of 11.8 and $21.5 \mathrm{~nm}$ respectively; (ii) the number of subunits to be fitted into the cylinder $\left(N_{\text {agg }}\right)$ is $35 \pm 2$; (iii) the subunits maintain a native-like fold as observed on FTIR spectra recorded during the early stages of heparin- induced aggregation (27); (iv) a native-like dimer can be used as the building block because this species is also present in the early stages of the fibrillation process (Fig. 2).

Using SymmDock (43), we generated 100 docking models taking the GAPDH dimer as building block. Based on the particle size restrictions derived from SAXS, we narrowed the possibilities down to only one model, which was then submitted to relaxation protocols through molecular dynamic simulations techniques. Because of the time and length scales needed for this study, we used a multiscale approach. The first step used was the MARTINI coarse grain force field with elastic network constraints (47) to perform the simulations (45). In the second step, all-atom detail was introduced back into the model (Fig. 3) by using the reverse transformation protocol described by Rzepiela et al. (48). This approach could preserve the overall fold of each subunit, as evidenced by the root mean square deviation of the subunits from its $x$-ray structure, which remained under $0.28 \mathrm{~nm}$ throughout the whole simulation. The presence of improper protein-protein contacts in the proposed protofibril model was evaluated by following the evolution of the protein's solvent-accessible surface area, where an increment is indicative of repulsions at the interfaces. The assembly model that we propose for the protofibril remains stable within the microsecond time scales (data not shown), indicating that there is no repulsion in the interfaces.

The reliability of the model obtained is given by the good agreement between the experimental and the theoretical distance distribution $p(r)$ function data as estimated with SASMOL software (Fig. 3) (37). According to our model, the protofibril has the shape of a cylinder with $21.6 \mathrm{~nm}$ height and $12.4 \mathrm{~nm}$ diameter. Within the protofibril, the dimers are arranged into layers of hexamers stacked along the long axis of the cylinder and presented a helical twist with a structure that repeats every 12 layers. It is important to note that in the model presented, the $\beta$-sheets within the catalytic domain of each subunit were oriented in tandem perpendicular to the elongation axis of the protofibril. Under this scheme, it seems to be possible that the flexible loops present in the interface between the layers might take another course, allowing the formation of a hydrogen bond network connecting these $\beta$-sheets, giving rise to the characteristic cross$\beta$-structure of the amyloid fibrils.

Thus, according to the proposed model, heparin induces changes in the quaternary structure of GAPDH leading to the formation of new protein-protein interfaces in the protofibril. Changes at the interfaces could be visualized by plotting the contact maps, which depict the proximity between two residues at the interface in the protofibril compared with the native tetramer (Fig. 3E). An analysis of our model shows that Tyr-39, Tyr-42, and Tyr-46 are in close proximity to the interface between three subunits in the core of the protofibril (Fig. 3, C and $E$ ). In the tetramer, these residues are exposed to the solvent and do not participate in the formation of protein-protein interfaces.

To understand the molecular basis of the interaction between the protofibril and $\alpha-\mathrm{SN}_{\text {oli }}$, we evaluated the exposure of hydrophobic patches on the protein surface. Hydrophobic interactions were shown to play an important role in protein

\footnotetext{
FIGURE 3. All-atom model of the heparin-induced GAPDH protofibril. $A$, surface representation of the whole protofibril (side view), with each layer colored in a different shade of green or pink; $B$, surface representation for one of the repetitive layers along the elongation axis (top view). The dimer formed between subunits $O$ and $P$ is represented in a transparent surface shown in schematic representation the $\beta$-sheets forming the intersubunit interface and that might be involved in the cross- $\beta$ structures in the mature fibril. $C$, surface representation of the contact between the dimeric building blocks at the core of the protofibril. Tyr residues 39,42, and 46 are represented in Licorice. D, pair distance distribution functions, $p(r)$, of the effective cylinder obtained from SAXS (solid line), along

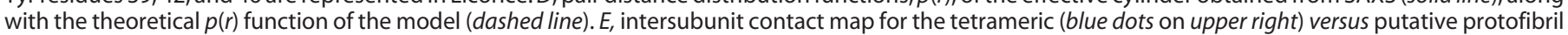
(red dots on upper left) assembly of GAPDH. The dotted line represents the position of the tyrosine residues. $F$, spatial aggregation propensity at $R=10$ mapped onto the protofibril solvent-accessible surface. The red regions indicate aggregation-prone sites with hydrophobic patches exposed.
} 


\section{Characterization of Neuroprotective GAPDH Protofibril}

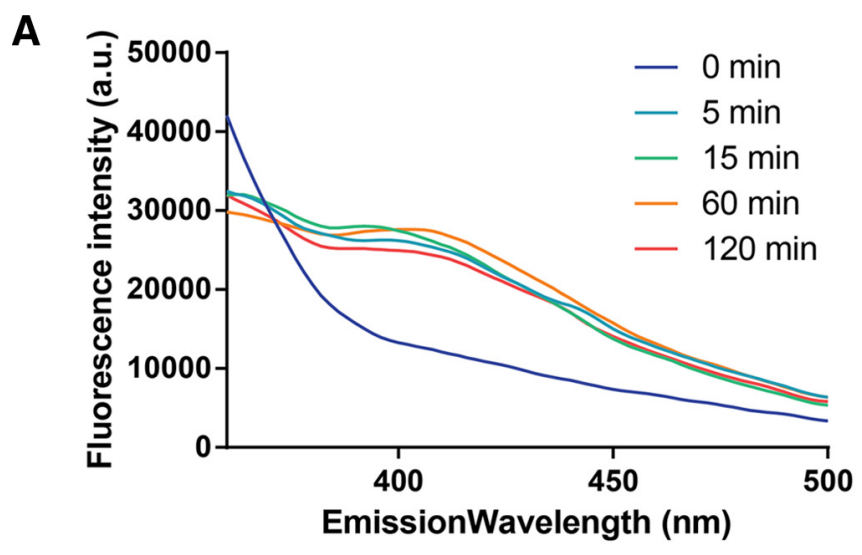

B

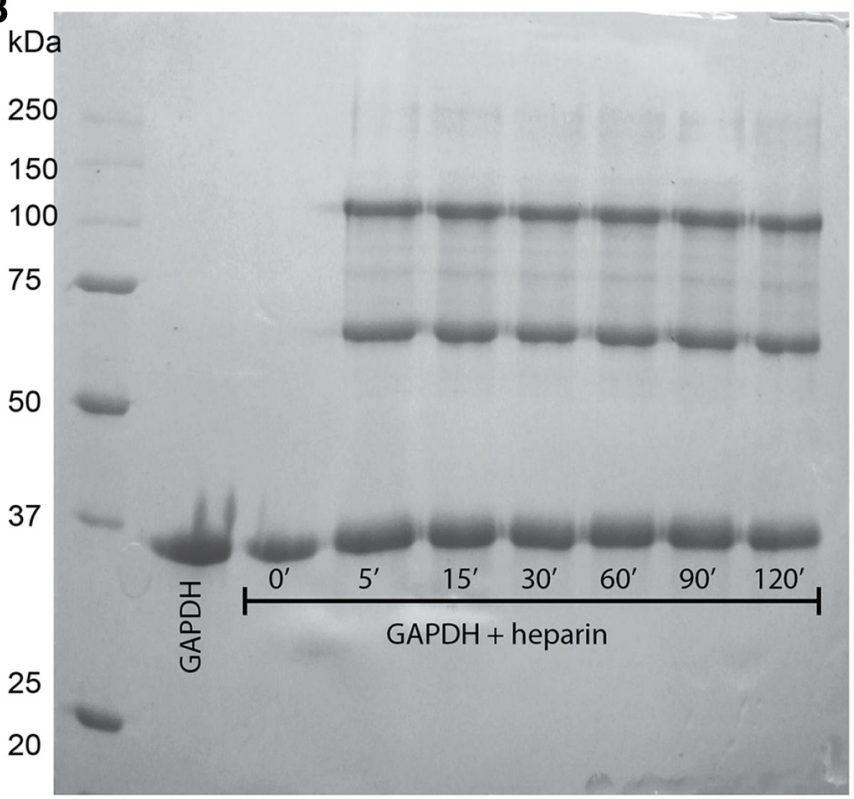

C

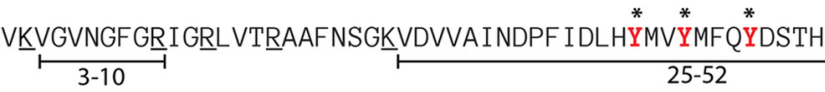

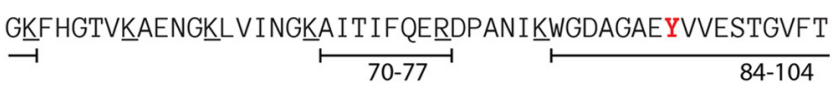

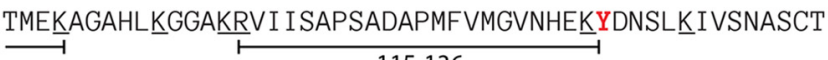
TNCLAPLAK VIHDHFGI VEGLMTTVHAITATQKKTVDGPSGKLLWRDGRGAA 160-183

QNI IPASTGAAKAVGKKVIPELNGKLLTGMAFRVPTPNVSVVDLTCRLLEKAA 225-245

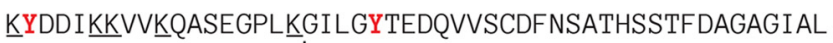
269-306

NDHFVKLL ISWYDNEFGYSNRVVDLMVHMASKKE

307-320 321-331

FIGURE 4. Characterization of new protein-protein interfaces in GAPDH protofibril. $A$, fluorescence emission spectral changes of the photolyzed solution of GAPDH incubated in the presence of heparin; excitation at $275 \mathrm{~nm}$ reflects the formation of Tyr-Tyr bonds. A.U., arbitrary units. B, electrophoresis gel of the GAPDH alone or after incubation with heparin at different time intervals treated with PICUP. C, amino acid sequence of GAPDH. Putative tryp- aggregation, and thus several algorithms were developed in an attempt to identify these regions. Aggregation-prone regions were predicted through the calculation of the spatial aggregation propensity (50). Mapping this parameter on the protein's surface reveals the presence of a hydrophobic patch at the edge of the protofibril (Fig. 3F). This hydrophobic patch might act as a scaffold for recruiting additional subunits of GAPDH for the elongation of the protofibril, as well as for recruiting $\alpha-\mathrm{SN}_{\text {oli }}$ into a mixed fibril.

Mass Spectrometry Validates the GAPDH Protofibril ModelTo experimentally validate the proposed GAPDH protofibrillar model, we resourced to covalent stabilization through photoinduced cross-linking of unmodified proteins (PICUP). This method allows the formation of Tyr-Tyr bonds when these residues are in close proximity (41). To do this, aliquots from an incubation mixture containing GAPDH and heparin were harvested at different times and photolyzed in the presence of tris(bipyridine)ruthenium(II) dichloride and ammonium persulfate. The formation of new di-tyrosine bonds was shown by the increase of the characteristic emission peak at $410 \mathrm{~nm}$ in the fluorescent spectra only in heparin-containing mixtures (Fig. $4 A$ ). The SDS-PAGE analysis (Fig. $4 B$ ) of each of these samples shows the presence of new covalently stabilized dimeric and trimeric GAPDH species. In the absence of heparin, no covalent cross-link was detected.

To identify the Tyr involved in new covalent bonds stabilizing the dimeric and trimeric species detected in the SDS-PAGE, we performed trypsin digestion of the isolated bands, followed by comparative analysis of the generated peptides using mass spectrometry. Most of the expected peptides were detected in the sample corresponding to the monomer (Fig. 4C). It is important to note the presence of a signal compatible with fragment 25-52 in the monomer sample, bearing Tyr-39, Tyr-42, and Tyr-46 which could be involved in the formation of TyrTyr bonds stabilizing the dimers or trimers (Table 2). Nevertheless, the signal compatible with the segment peptide 25-52 was no longer detected in dimer or trimer samples. On the contrary, the dimer and trimer digestion samples show the presence of additional signals, such as the one compatible with $\sim 9657 \mathrm{Da}$, which could be assigned to a new fragment formed by cross-linking Tyr residues between segment peptides 9-58 and 25-58.

The difference observed in the cross-linking properties of GAPDH might be understood in terms of the differences in the Tyr-Tyr interactions in the interface in the protofibril compared with the native tetramer (Fig. $3 E$ ). Accordingly, in the crystallographic structure of the native tetrameric protein, the region corresponding to fragment $25-52$ is exposed to the solvent, although on the protofibril this region is confined to the subunit-subunit interfaces, just at the core of each layer (Fig. 3E) allowing Tyr-39, Tyr-42, and Tyr-46 in close proximity for cross-linking. When the protofibril is

sin cleavage sites (Arg and Lys residues) are underlined. The peptide fragments detected on the MS/MS analysis of the monomer band are indicated below the sequence. Tyr residues available for cross-linking are depicted in red, and those forming Tyr-Tyr bridges in the PICUP-stabilized dimer and trimer are marked with asterisks. 
Characterization of Neuroprotective GAPDH Protofibril

TABLE 2

GAPDH peptides found in digested monomer, dimer, and trimer samples

Putative dipeptides bearing a di-tyrosine link are shown at the bottom of the table. NS indicates no signal.

\begin{tabular}{|c|c|c|c|c|}
\hline \multirow[b]{2}{*}{ Peptide fragment } & \multirow[b]{2}{*}{ Mass $\mathrm{H}^{+}$(theoretical) } & \multicolumn{3}{|c|}{ Mass $\mathrm{H}^{+}$(experimental) } \\
\hline & & Monomer & Dimer & Trimer \\
\hline $3-10$ & 805.4315 & 805.40 & 805.406799 & 805.399353 \\
\hline $25-52$ & 3317.5646 & 3317.72 & NS & NS \\
\hline $70-77$ & 977.5415 & 977.472778 & 977.497131 & 977.500793 \\
\hline $84-104$ & 2277.038 & 2277.04248 & 2276.95728 & 2276.073 \\
\hline $115-136$ & 2370.2283 & 2369.23364 & 2369.13135 & 2369.22168 \\
\hline $160-183$ & 2618.3759 & 2618.44653 & 2618.27832 & 2618.31665 \\
\hline $269-306$ & 4087.8614 & 4087.98267 & 4087.95044 & 4088.08081 \\
\hline $307-320$ & 1763.8024 & 1763.79981 & 1763.80115 & 1763.74927 \\
\hline $321-331$ & 1229.6381 & 1229.55957 & 1229.64111 & 1229.55627 \\
\hline $9-42$ and $25-39$ & 5536.8957 & NS & 5534.09 & \\
\hline $14-46$ and $25-44$ & 6238.0784 & NS & 6238.61 & \\
\hline $18-52$ and $35-52$ & 6238.60 & & & \\
\hline $14-63$ and $25-52$ & 8942.3633 & NS & 8943.81 & \\
\hline $9-58$ and $25-58$ & 9657.8132 & NS & 9657.75 & \\
\hline
\end{tabular}

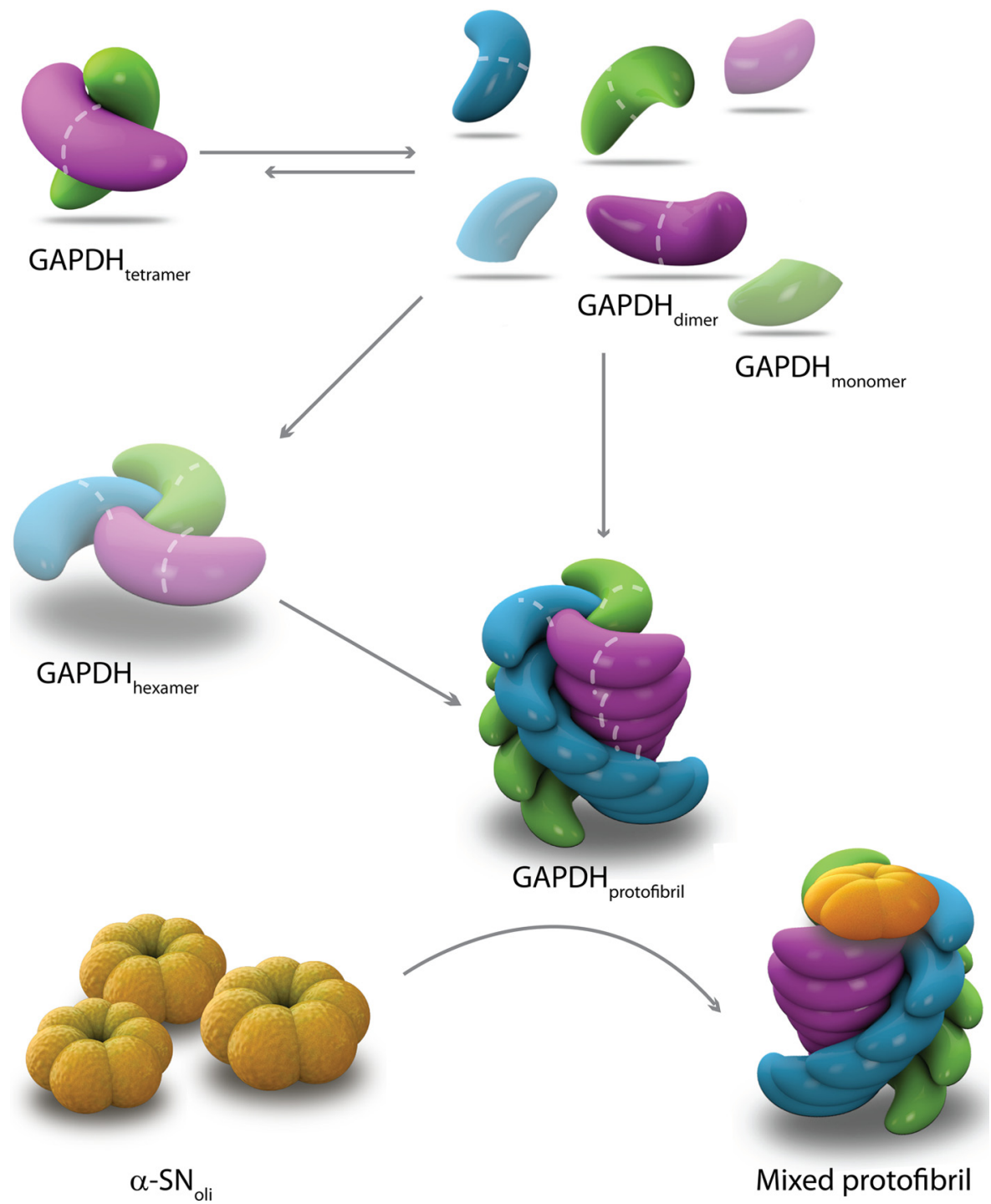

FIGURE 5. Schematic diagram of the heparin-induced GAPDH fibrillation pathway and its interaction with $\boldsymbol{\alpha}$-SN oli . Heparin interacts with GAPDH inducing dissociation of tetramer into dimers, which then reassemble into the growing protofibril. The existence of additional potential intermediates (shadowed monomer and hexamer) is also proposed. The model of interaction between GAPDH protofibrils and $\alpha$-SN $\mathrm{oli}_{\text {ol }}$ is based on the hydrophobic patch present at the edge of the protofibril allowing the recruitment $\alpha-\mathrm{SN}_{\text {oli }}$ into a mixed protofibril.

exposed to the denaturing conditions of SDS-PAGE, all the subunits disassemble except those with covalent stabilization, giving rise to the dimeric and trimeric species, along with the monomeric species (Fig. 4B). Altogether, these results give experimental support to the structural model proposed for the GAPDH protofibril. 


\section{Characterization of Neuroprotective GAPDH Protofibril}

\section{DISCUSSION}

We have previously shown that some intermediates present in the early stages of heparin-induced GAPDH amyloid aggregation (HI-GAPDH $\mathrm{ESS}_{\text {) }}$ ) are able to accelerate the kinetics of $\alpha$-SN aggregation. Here, we demonstrate that these HI$\mathrm{GAPDH}_{\mathrm{ESS}}$ species are able to abolish $\alpha-\mathrm{SN}_{\text {oli }}$ deleterious activity at the cell membrane level possibly by sequestering $\mathrm{SN}_{\text {oli }}$. Interestingly, the capacity of $\mathrm{HI}-\mathrm{GAPDH}_{\mathrm{ESS}}$ to reduce membrane damage (Fig. $1 F$ ) increases with the amount of protofibril species present in the solution (Fig. 2F). The protofibril revealed by the SAXS analysis composes a proteic cylinder-like envelope $22 \mathrm{~nm}$ long and a 6-nm radius. The all-atom model for such a protofibril, obtained using rigid body docking and molecular dynamics simulations, shows that GAPDH subunits are arranged into layers of hexamers stacked along the cylinder long axis with a helical twist that gives rise to a repeating structure every 12 layers. Also, the $\beta$-sheets within the catalytic domain of each subunit are oriented in tandem perpendicular to the elongation axis of the protofibril. We propose that the flexible loops present in the interface between the layers might take a new direction, allowing the formation of a hydrogen bond network connecting these $\beta$-sheets, giving rise to the characteristic cross- $\beta$-structure of the amyloid fibrils as observed by ThT fluorescence and FTIR spectroscopy (27). Cross-linking experiments coupled to mass spectrometry gives additional support to the model, validating the hypothesis that Tyr-39, Tyr-42, and Tyr-46 intervene in the formation of new protein-protein interfaces in the protofibril.

The structural characterization of the protofibril acquires relevance in view of its beneficial features. Using a dopaminergic cell model, we demonstrated the ability of heparin-induced GAPDH protofibrillar species to protect cells against exogenous addition of $\alpha-\mathrm{SN}_{\text {oli }}$. This protection seems to be mediated by abolishing the membrane perturbation induced by $\alpha-\mathrm{SN}_{\text {oli }}$, as indicated by fluorescence assays on a simplified cellular membrane model. It is tempting to speculate that heparin-induced GAPDH protofibrils behave as an efficient polymerization seed for $\alpha$-SN, acting as scavengers for $\alpha-\mathrm{SN}_{\text {oli }}$ toxic species, pushing them to reach the fibrillar nontoxic state, and preventing them from reaching the cytoplasmic membrane. In a previous work, we demonstrated the formation of a mixed fibril when GAPDH protofibrils are incubated in the presence of $\alpha-\mathrm{SN}_{\text {oli }}$ (27). The lack of an all atom model for $\alpha-\mathrm{SN}_{\text {oli }}$ species prevented us from applying the computational tool such as docking studies for inquiring on the specific nature of the protein-protein interaction. Still, several works have evidenced the relevance of hydrophobic interactions in protein aggregation. In particular, the algorithm SAP, which is based on the detection of hydrophobic patches on the protein surface, has proved useful for predicting putative aggregation-prone regions in proteins (50). An analysis of GAPDH protofibrils revealed a hydrophobic patch at the protofibril edge (Fig. 3), which could account for the recruitment of $\alpha-\mathrm{SN}_{\text {oli }}$ into a mixed protofibril as depicted in Fig. 5.

In this scenario, although $\alpha$-SN is mainly found in the cytosol, identification of this protein outside the cell $(65,66)$ suggests that $\alpha$-SN amyloid pathology may spread during disease progression $(3,4,67)$ possibly by a prion-like mechanism, i.e. by a self-templating change in protein structure (68). The GAPDH protofibril could play an important role sequestering $\alpha-\mathrm{SN}_{\text {oli }}$ species spreading through the extracellular space. Here, we used heparin to trigger the formation of GAPDH protofibrils, and although this GAG is not considered to exist inside the brain, it is representative of highly sulfated heparan sulfate domains classically found in the extracellular matrix of any tissue (69). In this scenario, a role for GAPDH protofibrils in cellular proteostasis seems possible because heparan sulfates from brain extracellular matrix can colocalize and thus interact with secreted GAPDH inducing its dissociation and reassociation into new species capable of scavenging $\alpha-\mathrm{SN}_{\text {oli }}$. According to our hypothesis, the dissociation of the tetramer into dimers represents a key step into the formation of species involved in proteostasis of $\alpha-\mathrm{SN}_{\text {oli }}$ (Fig. 5). We cannot deny the presence of monomers as well as additional structural species in solution which, if present, they might be in very small amounts and below the limits of detection of the methods used herein. Interestingly, drugs used for the treatment of Parkinson disease increase the stability of GAPDH as a dimer (70). This mechanism could be involved in neuroprotection and represents a new strategy for therapeutic design in Parkinson disease.

Acknowledgments-We thank the National Laboratory of Synchrotron Light (Campinas, SP, Brazil) for the use of SAXS beam line facilities and Centro Nacional de Supercomputaçao-Universidad Federal do Rio Grande do Sul (Porto Alegre, Brazil) for the computational clusters facilities. We also thank Profs. Paolo Mariani and Francesco Spinozzi, both from Universitá Politecnica delle Marche, Ancona, Italy, who provided us with the GENFIT software.

\section{REFERENCES}

1. Spillantini, M. G., Crowther, R. A., Jakes, R., Hasegawa, M., and Goedert, M. (1998) $\alpha$-Synuclein in filamentous inclusions of Lewy bodies from Parkinson's disease and dementia with Lewy bodies. Proc. Natl. Acad. Sci. U.S.A. 95, 6469-6473

2. Lee, H. J., Patel, S., and Lee, S. J. (2005) Intravesicular localization and exocytosis of $\alpha$-synuclein and its aggregates. J. Neurosci. 25, 6016-6024

3. Lee, H. J., Suk, J. E., Bae, E. J., and Lee, S. J. (2008) Clearance and deposition of extracellular $\alpha$-synuclein aggregates in microglia. Biochem. Biophys. Res. Commun. 372, 423-428

4. Lee, S. J. (2008) Origins and effects of extracellular $\alpha$-synuclein: implications in Parkinson's disease. J. Mol. Neurosci. 34, 17-22

5. Chai, Y. J., Kim, D., Park, J., Zhao, H., Lee, S. J., and Chang, S. (2013) The secreted oligomeric form of $\alpha$-synuclein affects multiple steps of membrane trafficking. FEBS Lett. 587, 452-459

6. Steiner, J. A., Angot, E., and Brundin, P. (2011) A deadly spread: cellular mechanisms of $\alpha$-synuclein transfer. Cell Death Differ. 18, 1425-1433

7. Wood, S. J., Wypych, J., Steavenson, S., Louis, J. C., Citron, M., and Biere, A. L. (1999) $\alpha$-Synuclein fibrillogenesis is nucleation-dependent. Implications for the pathogenesis of Parkinson's disease. J. Biol. Chem. 274, $19509-19512$

8. Conway, K. A., Harper, J. D., and Lansbury, P. T., Jr. (2000) Fibrils formed in vitro from $\alpha$-synuclein and two mutant forms linked to Parkinson's disease are typical amyloid. Biochemistry 39, 2552-2563

9. Chiti, F., and Dobson, C. M. (2006) Protein misfolding, functional amyloid, and human disease. Annu. Rev. Biochem. 75, 333-366

10. Caughey, B., and Lansbury, P. T. (2003) Protofibrils, pores, fibrils, and neurodegeneration: separating the responsible protein aggregates from the innocent bystanders. Annu. Rev. Neurosci. 26, 267-298

11. Cremades, N., Cohen, S. I., Deas, E., Abramov, A. Y., Chen, A. Y., Orte, A., Sandal, M., Clarke, R. W., Dunne, P., Aprile, F. A., Bertoncini, C. W., 
Wood, N. W., Knowles, T. P., Dobson, C. M., and Klenerman, D. (2012) Direct observation of the interconversion of normal and toxic forms of $\alpha$-synuclein. Cell 149, $1048-1059$

12. Butterfield, S. M., and Lashuel, H. A. (2010) Amyloidogenic protein-membrane interactions: mechanistic insight from model systems. Angew Chem. Int. Ed. Engl. 49, 5628-5654

13. Tsuchiya, K., Tajima, H., Kuwae, T., Takeshima, T., Nakano, T., Tanaka, M., Sunaga, K., Fukuhara, Y., Nakashima, K., Ohama, E., Mochizuki, H., Mizuno, Y., Katsube, N., and Ishitani, R. (2005) Pro-apoptotic protein glyceraldehyde-3-phosphate dehydrogenase promotes the formation of Lewy body-like inclusions. Eur. J. Neurosci. 21, 317-326

14. Leverenz, J. B., Umar, I., Wang, Q., Montine, T. J., McMillan, P. J., Tsuang, D. W., Jin, J., Pan, C., Shin, J., Zhu, D., and Zhang, J. (2007) Proteomic identification of novel proteins in cortical Lewy bodies. Brain Pathol. 17, $139-145$

15. Sirover, M. A. (2011) On the functional diversity of glyceraldehyde-3phosphate dehydrogenase: biochemical mechanisms and regulatory control. Biochim. Biophys. Acta 1810, 741-751

16. Zheng, L., Roeder, R. G., and Luo, Y. (2003) S phase activation of the histone $\mathrm{H} 2 \mathrm{~B}$ promoter by OCA-S, a coactivator complex that contains GAPDH as a key component. Cell 114, 255-266

17. Engel, M., Seifert, M., Theisinger, B., Seyfert, U., and Welter, C. (1998) Glyceraldehyde-3-phosphate dehydrogenase and Nm23-H1/nucleoside diphosphate kinase A. Two old enzymes combine for the novel Nm23 protein phosphotransferase function. J. Biol. Chem. 273, 20058-20065

18. Kumagai, H., and Sakai, H. (1983) A porcine brain protein (35 K protein) which bundles microtubules and its identification as glyceraldehyde 3-phosphate dehydrogenase. J. Biochem. 93, 1259-1269

19. Xu, K. Y., and Becker, L. C. (1998) Ultrastructural localization of glycolytic enzymes on sarcoplasmic reticulum vesicles. J. Histochem. Cytochem. 46, $419-427$

20. Lin, H., Zhu, Y. J., and Lal, R. (1999) Amyloid $\beta$ protein(1-40) forms calcium-permeable, $\mathrm{Zn}^{2+}$-sensitive channel in reconstituted lipid vesicles. Biochemistry 38, 11189-11196

21. Hara, M. R., Agrawal, N., Kim, S. F., Cascio, M. B., Fujimuro, M., Ozeki, Y., Takahashi, M., Cheah, J. H., Tankou, S. K., Hester, L. D., Ferris, C. D., Hayward, S. D., Snyder, S. H., and Sawa, A. (2005) S-Nitrosylated GAPDH initiates apoptotic cell death by nuclear translocation following Siah1 binding. Nat. Cell Biol. 7, 665-674

22. Butterfield, D. A., Hardas, S. S., and Lange, M. L. (2010) Oxidatively modified glyceraldehyde-3-phosphate dehydrogenase (GAPDH) and Alzheimer's disease: many pathways to neurodegeneration. J. Alzheimers Dis. 20, 369-393

23. Allen, M., Cox, C., Belbin, O., Ma, L., Bisceglio, G. D., Wilcox, S. L., Howell, C. C., Hunter, T. A., Culley, O., Walker, L. P., Carrasquillo, M. M., Dickson, D. W., Petersen, R. C., Graff-Radford, N. R., Younkin, S. G., and Ertekin-Taner, N. (2010) Association and heterogeneity at the GAPDH locus in Alzheimer's disease. Neurobiol. Aging 33, 203 e225-e233

24. Díaz-Nido, J., Wandosell, F., and Avila, J. (2002) Glycosaminoglycans and $\beta$-amyloid, prion and tau peptides in neurodegenerative diseases. Peptides 23, 1323-1332

25. Holmes, B. B., DeVos, S. L., Kfoury, N., Li, M., Jacks, R., Yanamandra, K. Ouidja, M. O., Brodsky, F. M., Marasa, J., Bagchi, D. P., Kotzbauer, P. T. Miller, T. M., Papy-Garcia, D., and Diamond, M. I. (2013) Heparan sulfate proteoglycans mediate internalization and propagation of specific proteopathic seeds. Proc. Natl. Acad. Sci. U.S.A. 110, E3138 -E3147

26. Motamedi-Shad, N., Monsellier, E., Torrassa, S., Relini, A., and Chiti, F. (2009) Kinetic analysis of amyloid formation in the presence of heparan sulfate: faster unfolding and change of pathway. J. Biol. Chem. 284, 29921-29934

27. Torres-Bugeau, C. M., Ávila, C. L., Raisman-Vozari, R., Papy-Garcia, D., Itri, R., Barbosa, L. R., Cortez, L. M., Sim, V. L., and Chehín, R. N. (2012) Characterization of heparin-induced glyceraldehyde-3-phosphate dehydrogenase early amyloid-like oligomers and their implication in $\alpha$-synuclein aggregation. J. Biol. Chem. 287, 2398-2409

28. Hoyer, W., Antony, T., Cherny, D., Heim, G., Jovin, T. M., and Subramaniam, V. (2002) Dependence of $\alpha$-synuclein aggregate morphology on solution conditions. J. Mol. Biol. 322, 383-393
29. Kaylor, J., Bodner, N., Edridge, S., Yamin, G., Hong, D. P., and Fink, A. L. (2005) Characterization of oligomeric intermediates in $\alpha$-synuclein fibrillation: FRET studies of Y125W/Y133F/Y136F $\alpha$-synuclein. J. Mol. Biol. 353, 357-372

30. Danzer, K. M., Haasen, D., Karow, A. R., Moussaud, S., Habeck, M., Giese, A., Kretzschmar, H., Hengerer, B., and Kostka, M. (2007) Different species of $\alpha$-synuclein oligomers induce calcium influx and seeding. J. Neurosci. 27, 9220-9232

31. Arrondo, J. L., Castresana, J., Valpuesta, J. M., and Goñi, F. M. (1994) Structure and thermal denaturation of crystalline and noncrystalline cytochrome oxidase as studied by infrared spectroscopy. Biochemistry 33, $11650-11655$

32. Mosmann, T. (1983) Rapid colorimetric assay for cellular growth and survival: application to proliferation and cytotoxicity assays. J. Immunol. Methods 65, 55-63

33. Folch, J., Lees, M., and Sloane Stanley, G. H. (1957) A simple method for the isolation and purification of total lipids from animal tissues. J. Biol. Chem. 226, 497-509

34. Finer, E. G., Flook, A. G., and Hauser, H. (1972) Mechanism of sonication of aqueous egg yolk lecithin dispersions and nature of the resultant particles. Biochim. Biophys. Acta 260, 49-58

35. Kendall, D. A., and MacDonald, R. C. (1982) A fluorescence assay to monitor vesicle fusion and lysis. J. Biol. Chem. 257, 13892-13895

36. Barbosa, L. R., Spinozzi, F., Mariani, P., and Itri, R. (2013) in Proteins in Solution and at Interfaces (Ruso, J. M., and Piñeiro, A., eds) pp. 49-72, John Wiley \& Sons, Inc., New York

37. Ortore, M. G., Spinozzi, F., Mariani, P., Paciaroni, A., Barbosa, L. R., Amenitsch, H., Steinhart, M., Ollivier, J., and Russo, D. (2009) Combining structure and dynamics: nondenaturing high-pressure effect on lysozyme in solution. J. R. Soc. Interface 6, S619-S634

38. Barbosa, L. R., Ortore, M. G., Spinozzi, F., Mariani, P., Bernstorff, S., and Itri, R. (2010) The importance of protein-protein interactions on the $\mathrm{pH}$ induced conformational changes of bovine serum albumin: a small-angle x-ray scattering study. Biophys. J. 98, 147-157

39. Fournet, G., and Guinier, A. (1955) Small Angle Scattering of X-rays (translated by Walker, C. B., and Yudowitch, K. L.) pp. 7-78, John Wiley \& Sons, Inc., New York

40. Fancy, D. A., Denison, C., Kim, K., Xie, Y., Holdeman, T., Amini, F., and Kodadek, T. (2000) Scope, limitations and mechanistic aspects of the photo-induced cross-linking of proteins by water-soluble metal complexes. Chem. Biol. 7, 697-708

41. Fancy, D. A., and Kodadek, T. (1999) Chemistry for the analysis of proteinprotein interactions: rapid and efficient cross-linking triggered by long wavelength light. Proc. Natl. Acad. Sci. U.S.A. 96, 6020-6024

42. Weber, K., and Osborn, M. (1969) The reliability of molecular weight determinations by dodecyl sulfate-polyacrylamide gel electrophoresis. J. Biol. Chem. 244, 4406-4412

43. Schneidman-Duhovny, D., Inbar, Y., Nussinov, R., and Wolfson, H. J. (2005) Geometry-based flexible and symmetric protein docking. Proteins 60, 224-231

44. Cowan-Jacob, S. W., Kaufmann, M., Anselmo, A. N., Stark, W., and Grütter, M. G. (2003) Structure of rabbit-muscle glyceraldehyde-3-phosphate dehydrogenase. Acta Crystallogr. D. Biol. Crystallogr. 59, 2218-2227

45. Marrink, S. J., Risselada, H. J., Yefimov, S., Tieleman, D. P., and de Vries, A. H. (2007) The MARTINI force field: coarse grained model for biomolecular simulations. J. Phys. Chem. B. 111, 7812-7824.

46. Monticelli, L., Kandasamy, S. K., Periole, X., Larson, R. G., Tieleman, D. P., and Marrink, S.-J. (2008) The MARTINI coarse-grained force field: Extension to proteins. J. Chem. Theory Comput. 4, 819-834

47. Periole, X., Cavalli, M., Marrink, S.-J., and Ceruso, M. A. (2009) Combining an elastic network with a coarse-grained molecular force field: Structure, dynamics, and intermolecular recognition. J. Chem. Theory Comput. 5, 2531-2543

48. Rzepiela, A. J., Schäfer, L. V., Goga, N., Risselada, H. J., De Vries, A. H., and Marrink, S. J. (2010) Reconstruction of atomistic details from coarsegrained structures. J. Comput. Chem. 31, 1333-1343

49. Vendruscolo, M., Najmanovich, R., and Domany, E. (1999) Protein folding in contact map space. Phys. Rev. Lett. 82, 656-659 


\section{Characterization of Neuroprotective GAPDH Protofibril}

50. Chennamsetty, N., Voynov, V., Kayser, V., Helk, B., and Trout, B. L. (2009) Design of therapeutic proteins with enhanced stability. Proc. Natl. Acad. Sci. U.S.A. 106, 11937-11942

51. Humphrey, W., Dalke, A., and Schulten, K. (1996) VMD: visual molecular dynamics. J. Mol. Graph. 14, 33-38

52. Black, S. D., and Mould, D. R. (1991) Development of hydrophobicity parameters to analyze proteins which bear post- or cotranslational modifications. Anal. Biochem. 193, 72-82

53. Yang, W. H., Yang, C., Xue, Y. Q., Lu, T., Reiser, J., Zhao, L. R., and Duan, W. M. (2013) Regulated expression of lentivirus-mediated GDNF in human bone marrow-derived mesenchymal stem cells and its neuroprotection on dopaminergic cells in vitro. PLoS One 8, e64389

54. Kim, H. Y., Cho, M. K., Kumar, A., Maier, E., Siebenhaar, C., Becker, S., Fernandez, C. O., Lashuel, H. A., Benz, R., Lange, A., and Zweckstetter, M. (2009) Structural properties of pore-forming oligomers of $\alpha$-synuclein. J. Am. Chem. Soc. 131, 17482-17489

55. Glabe, C. G. (2008) Structural classification of toxic amyloid oligomers. J. Biol. Chem. 283, 29639-29643

56. Kayed, R., Sokolov, Y., Edmonds, B., McIntire, T. M., Milton, S. C., Hall, J. E., and Glabe, C. G. (2004) Permeabilization of lipid bilayers is a common conformation-dependent activity of soluble amyloid oligomers in protein misfolding diseases. J. Biol. Chem. 279, 46363-46366

57. Volles, M. J., Lee, S. J., Rochet, J. C., Shtilerman, M. D., Ding, T. T., Kessler, J. C., and Lansbury, P. T., Jr. (2001) Vesicle permeabilization by protofibrillar $\alpha$-synuclein: implications for the pathogenesis and treatment of Parkinson's disease. Biochemistry 40, 7812-7819

58. van Rooijen, B. D., Claessens, M. M., and Subramaniam, V. (2010) Membrane permeabilization by oligomeric $\alpha$-synuclein: in search of the mechanism. PLoS One 5, e14292

59. Morero, R. D., Viñals, A. L., Bloj, B., and Farías, R. N. (1985) Fusion of phospholipid vesicles induced by muscle glyceraldehyde-3-phosphate dehydrogenase in the absence of calcium. Biochemistry 24, 1904-1909

60. Oliveira, C. L., Behrens, M. A., Pedersen, J. S., Erlacher, K., and Otzen, D. (2009) A SAXS study of glucagon fibrillation. J. Mol. Biol. 387, 147-161

61. Giehm, L., Svergun, D. I., Otzen, D. E., and Vestergaard, B. (2011) Lowresolution structure of a vesicle disrupting $\alpha$-synuclein oligomer that accumulates during fibrillation. Proc. Natl. Acad. Sci. U.S.A. 108, 3246-3251
62. Spinozzi, F., Mariani, P., Saturni, L., Carsughi, F., Bernstorff, S., Cinelli, S., and Onori, G. (2007) Met-myoglobin association in dilute solution during pressure-induced denaturation: an analysis at $\mathrm{pH} 4.5$ by high-pressure small-angle x-ray scattering. J. Phys. Chem. B. 111, 3822-3830

63. Ortore, M. G., Spinozzi, F., Vilasi, S., Sirangelo, I., Irace, G., Shukla, A., Narayanan, T., Sinibaldi, R., and Mariani, P. (2011) Time-resolved smallangle x-ray scattering study of the early stage of amyloid formation of an apomyoglobin mutant. Phys. Rev. E. Stat. Nonlin. Soft Matter Phys. 84, 061904

64. Kodali, R., and Wetzel, R. (2007) Polymorphism in the intermediates and products of amyloid assembly. Curr. Opin. Struct. Biol. 17, 48-57

65. El-Agnaf, O. M., Salem, S. A., Paleologou, K. E., Cooper, L. J., Fullwood, N. J., Gibson, M. J., Curran, M. D., Court, J. A., Mann, D. M., Ikeda, S., Cookson, M. R., Hardy, J., and Allsop, D. (2003) $\alpha$-Synuclein implicated in Parkinson's disease is present in extracellular biological fluids, including human plasma. FASEB J. 17, 1945-1947

66. El-Agnaf, O. M., Salem, S. A., Paleologou, K. E., Curran, M. D., Gibson, M. J., Court, J. A., Schlossmacher, M. G., and Allsop, D. (2006) Detection of oligomeric forms of $\alpha$-synuclein protein in human plasma as a potential biomarker for Parkinson's disease. FASEB J. 20, 419-425

67. Luk, K. C., Song, C., O’Brien, P., Stieber, A., Branch, J. R., Brunden, K. R., Trojanowski, J. Q., and Lee, V. M. (2009) Exogenous $\alpha$-synuclein fibrils seed the formation of Lewy body-like intracellular inclusions in cultured cells. Proc. Natl. Acad. Sci. U.S.A. 106, 20051-20056

68. Sacino, A. N., and Giasson, B. I. (2012) Does a prion-like mechanism play a major role in the apparent spread of $\alpha$-synuclein pathology? Alzheimers Res. Ther. 4, 48

69. Huynh, M. B., Morin, C., Carpentier, G., Garcia-Filipe, S., Talhas-Perret, S., Barbier-Chassefière, V., van Kuppevelt, T. H., Martelly, I., Albanese, P., and Papy-Garcia, D. (2012) Age-related changes in rat myocardium involve altered capacities of glycosaminoglycans to potentiate growth factor functions and heparan sulfate-altered sulfation. J. Biol. Chem. 287, 11363-11373

70. Carlile, G. W., Chalmers-Redman, R. M., Tatton, N. A., Pong, A., Borden, K. E., and Tatton, W. G. (2000) Reduced apoptosis after nerve growth factor and serum withdrawal: conversion of tetrameric glyceraldehyde-3phosphate dehydrogenase to a dimer. Mol. Pharmacol. 57, 2-12 


\title{
CAPÍtULO 7
}

\author{
ESPALHAMENTO DE RAIOS-X A BAIXOS ÂNGULOS (SAXS) APLICADO AO \\ ESTUDO DE PROTEÍNAS NÃO INTERAGENTES EM SOLUÇÃO
}

Rosangela Itri ${ }^{1 *}$, Elisa Morandé Sales ${ }^{1,2}$ e Leandro R. S. Barbosa ${ }^{1}$

'Instituto de Física da Universidade de São Paulo, SP, Brasil 'Instituto de Pesquisas Tecnológicas do Estado de São Paulo, SP, Brasil

*Autor para correspondencia. Dirección de correo electrónico: itri@if.usp.br

\section{RESUMO}

Propriedades estruturais de sistemas biomoleculares com dimensões da ordem de poucos nanometros a dezenas de nanometros podem ser investigadas pela técnica de espalhamento de RX a baixos ângulos (SAXS). Em particular, tamanho, forma e estados conformacionais de toxinas/ proteinas podem ser determinadas a partir das curvas de espalhamento, assim como suas interações dependendo do meio aonde se encontram (dispersas em solução ou interagindo com membranas). No presente capítulo, apresentamos uma revisão da teoria básica e análise de dados de SAXS, incluindo a determinação do raio de giro de proteínas através da lei de Guinier e da função de distribuição de distâncias p(r). Particular ênfase será dada a exemplos de proteínas dispersas em solução e seus possíveis estados de agregação.

\section{ABSTRACT}

Small-angle scattering (SAS) is a powerful tool to investigate structural properties of biomolecular systems in solution. In particular, size, shape and conformational states of the toxins/proteins can be determined along with their interactions depending on the environment. In the current chap- 
ter, an overview of the basic theory and data analysis including determination of protein radius of gyration through Guinier's law and distance distribution function $p(r)$ will be presented and discussed. Particular emphasis will be placed to examples containing proteins in folded and unfolded states and aggregated states.

\section{INTRODUÇÃO}

A técnica de espalhamento de raios-X a baixos ângulos (SAXS, do inglês Small Angle X-ray Scattering) é uma ferramenta muito útil no estudo em baixa resolução de sistemas macromoleculares, permitindo avaliar o formato, as dimensões e possiveis interações entre objetos espalhadores.

De uma maneira geral, o arranjo experimental consiste de um feixe de raios- $X(R X)$, proveniente de uma fonte policromática (que pode ser convencional como um tubo de RX ou de radiação síncrotron), que incide inicialmente num monocromador, definindo seu comprimento de onda (esquema exemplificado na Fig. 1). O feixe atravessa então um sistema de colimação o que permite a retirada de espalhamento parasita (Fig. 1), e atinge a amostra. Geralmente toda esta região está em baixa pressão, para que o espalhamento produzido pelo ar seja desprezivel. Após interagir com a amostra, o feixe de raios $X$ atravessa um caminho de vácuo, cuja função é, novamente, diminuir a influência do espalhamento do ar na curva de SAXS. Ao final, os fótons de raios- $X$ atingem o detector, que pode ser uma placa de imagem ou um detector eletrônico (Fig 1).

Devido a uma grande distância entre a amostra e o detector, o ângulo de espalhamento, $2 \theta$, é pequeno (ver Fig. 1). $O$ ângulo $2 \theta$ é definido como $o$ ângulo entre o feixe de raio-X que atravessa a amostra e não é espalhado e um fóton que altera a direção de sua trajetória e atinge o detector em uma certa posição.

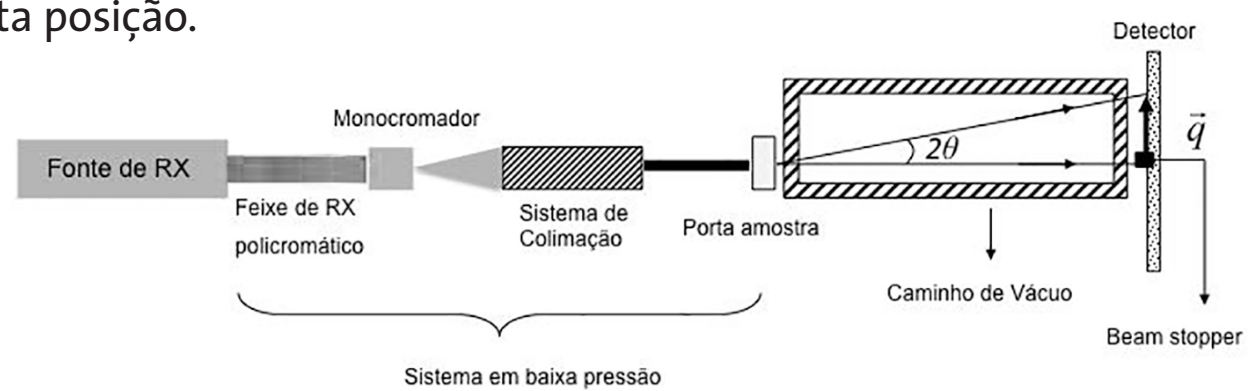

Figura 1. Esquema da linha de SAXS do Laboratório Nacional de Luz Síncrotron, LNLS, Campinas (distância amostra-detector de 1 a $2 \mathrm{~m}$ ). 
Define-se vetor de espalhamento, $\mathbf{q}$, como a diferença vetorial entre 0 feixe de raios-X que emerge da amostra sem interagir com a mesma e aquele que é espalhado e atinge o detector numa dada posição, conforme Fig. 2.

$$
\vec{q}=\vec{k}_{\text {out }_{2}}-\vec{k}_{\text {out }_{1}}
$$

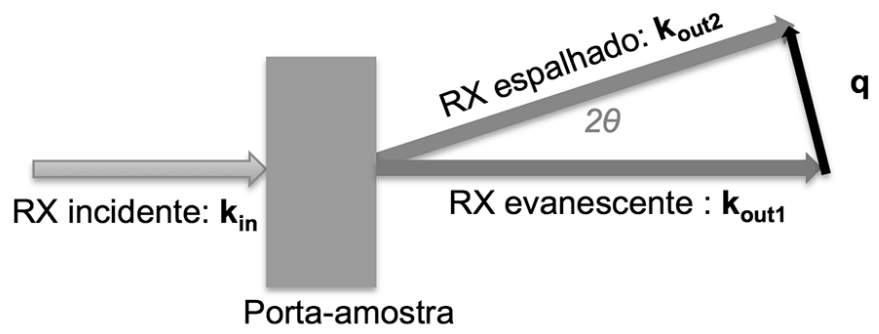

Figura 2. Esquema do vetor de espalhamento q.

Os vetores $\vec{k}_{\text {out }_{1} \text { e }} \vec{k}_{\text {out }_{2} \text { são os chamados vetores de onda e sua }}$ direção aponta para a direção de propagação da onda eletromagnética. Eles são definidos como: $K_{i}=\frac{2 \pi}{\lambda_{i}}$, onde $\lambda_{i}$ é o comprimento de onda da radiação.

Como veremos adiante, no caso de espalhamento em ângulos pequenos, podemos considerar apenas o chamado espalhamento elástico, onde a energia e, portanto, o comprimento de onda da radiação incidente, não são alterados durante o processo de espalhamento. Desta maneira, utilizando o teorema dos cossenos, teremos que:

$$
\begin{gathered}
\vec{q}=\vec{k}_{\text {out }_{2}}-\vec{k}_{\text {out }_{1}} \\
q^{2}=k_{\text {out }_{1}}^{2}+k_{\text {out }_{2}}^{2}-2 k_{\text {out }_{1}} k_{\text {out }_{2}} \cos (2 \theta) \\
\therefore \mathrm{q}=\frac{4 \pi}{\lambda} \sin (\theta)
\end{gathered}
$$

Sendo assim, o módulo do vetor de espalhamento, q, é diretamente 
proporcional ao ângulo de espalhamento e inversamente proporcional ao comprimento de onda da radiação.

\section{¿Quais tamanhos podemos medir?}

De maneira simplificada sabemos pela lei de Bragg:

$$
\mathrm{n} \lambda=2 \mathrm{~d} \sin (\theta)
$$

para ${ }_{1}{ }^{\mathrm{a}}$ ordem de difração $(\mathrm{n}=1)$, sendo d = distância entre centros espalhadores. Utilizando as Equações acimapodemos escrever que $d=\frac{2 \pi}{q}$.

Assim, percebemos que existe uma relação inversa entre o vetor de espalhamento medido e a dimensão do que se pretende avaliar. Quanto maior a dimensão, menor deve ser q (e portanto $2 \theta$ ) medido. Em geral, a técnica de SAXS se aplica para partículas espalhadoras cujas dimensões variam de 1 até cerca de $100 \mathrm{~nm}$ (10 a $1000 \AA$ ).

\section{TEORIA DE SAXS}

Conforme descrevemos acima, o espalhamento de RX a baixos ângulos consiste apenas no espalhamento elástico, ou seja, existe conservação da energia da radiação incidente e espalhada. Esse é um ponto importante pois as contribuições de espalhamento inelástico são despreziveis em baixos ângulos. Basta lembrar que o espalhamento Compton possui uma dependência angular que, para pequenos valores de $2 \theta$, pode ser considerada desprezível. Não consideramos também o chamado espalhamento múltiplo, ou seja, apenas um evento de espalhamento ocorre enquanto um fóton de Raio-X atravessa a amostra. Esta é uma aproximação indispensável para a descrição teórica da técnica, e pode ser tomada sem muitas preocupações, uma vez que a probabilidade de interação do raios-X com a matéria é baixa.

Além disso, são feitas as seguintes considerações: 
- o sistema é isotrópico e composto por partículas idênticas (também chamados objetos espalhadores); trópica;

- a disposição das partículas ao redor da partícula de referência é iso-

- não há flutuações no número de partículas espalhadoras.

De modo geral, a intensidade de espalhamento, pode ser escrita como:

$$
I(q)=V^{-1}\left\langle\left|\sum_{l=1}^{N} b_{l} e^{i \vec{q} \cdot \vec{r}_{l}}\right|^{2}\right\rangle
$$

onde $V$ é o volume da amostra, $b$, é o coeficiente de espalhamento (que depende do tipo de radiação incidente), $\vec{r}_{l}$ é a posição do centro de espalhamento I (elétrons no caso de RX) com relação a uma origem arbitrária.

Considerando que o sistema seja isotrópico e homogêneo, podemos dividir a amostra em $N_{p}$ células, sendo que em cada célula temos uma única partícula espalhadora (como consequência existem $N_{p}$ partículas espalhadoras) e as células são idênticas entre si. Assim, podemos calcular o espaIhamento de uma célula e somar a contribuição de todas as células, pois a intensidade tem propriedade aditiva. Neste caso a intensidade de espalhamento pode ser escrita como (Guinier e Fournet, 1955; Barbosa et al., 2013):

$$
I(q)=V^{-1}\left\langle\left|\sum_{i=1}^{N_{p}} \sum_{j=1}^{N_{i}} b_{i j} e^{i \vec{q} \cdot \vec{r}_{i j}}\right|^{2}\right\rangle
$$

onde $r_{i j}$ é a posição do centro de espalhamento $j$ dentro da célula $i, b_{i j}$ é o coeficiente de espalhamento deste mesmo centro espalhador e $N_{i}$ é o número de centros espalhadores dentro de uma única célula (uma partícula espalhadora é formada, portanto, por $N_{i}$ centros espalhadores, ver Fig. 2). É importante notar que apenas separamos a soma inicial em duas, uma relacionando os elétrons que pertencem a mesma célula e outra considernado elétrons das diferentes células.

Podemos, ainda, descrever a posição de cada um desses centros espalhadores em relação à célula em que este está contido como sendo:

$$
\vec{r}_{i j}=\vec{R}_{i}+\vec{X}_{j} \text {, onde } R_{i} \text { é a posição do centro de massa da célula }
$$


em relação a uma origem arbitrária na amostra e $\boldsymbol{X}_{j}$ é a posição do centro de espalhamento $j$, com relação ao centro de massa, mas desta vez da célula unitária, definido pela posição de $\boldsymbol{R}_{i}$. Substituindo $\boldsymbol{r}_{i j}$ na Equação 2, temos:

$$
I(q)=V^{-1}\left\langle\left|\sum_{i=1}^{N_{p}} e^{i \vec{q} \cdot \vec{R}_{i}} \sum_{j=1}^{N_{i}} b_{i j} e^{i \vec{q} \cdot \vec{X}_{j}}\right|^{2}\right\rangle
$$

Definimos a soma $\sum_{j=1}^{N_{i}} b_{i j} e^{i \vec{q} \cdot \vec{X}_{j}} \equiv F_{i}(q)$ como o fator de amplitude de espalhamento da célula $i$.

Por fim, a intensidade de espalhamento pode ser escrita como (lembrando que o módulo de um número complexo é igual a raiz quadradado produto deste número pelo seu complexo conjugado):

$$
I(q)=V^{-1}\left\langle\sum_{i=1}^{N_{p}} \sum_{i^{\prime}=1}^{N_{p}} F_{i}(q) F_{i^{\prime}}^{*}(q) e^{i \vec{q} \cdot\left(\vec{R}_{i}-\vec{R}_{i^{\prime}}\right)}\right\rangle
$$

onde $\left.\overrightarrow{ }_{i}-\vec{R}_{i^{\prime}}\right)$ é a distância entre dois centros espalhadores das células $i$ e $i$ ' $e^{*}$ indica o complexo conjugado de uma dada função.

É conveniente escrever a função $F_{i}(q)$, ao invés de uma soma discreta, como

sendo: $F_{i}(q)=\int d^{3} \vec{r} \rho_{i}(r) e^{i \vec{q} \vec{r}}$

sendo $\underset{\rho_{i}}{\longrightarrow}(r)=\sum_{j=1}^{N_{j}} g_{j}(q) \delta\left(\vec{r}-\overrightarrow{X_{j}}\right)$

onde $\vec{X}_{J}$ é a posição de cada centro espalhador com relação a célula $j, g_{j}(q)$, é o fator de espalhamento que depende do tipo de interação da onda (ou feixe de partículas) incidente com a partícula em estudo, $\delta(x)$ é a função de Dirac.

Reescrevemos o termo $g_{i}(q)$ como sendo o produto da Amplitude de espalhamento de um elétron $\left(A_{e}\right)$ (que depende da intensidade da onda incidente e da distância da amostra ao detector) pelo fator de espalhamento de um único elétron $\left(f_{i}(q)\right)$ (que depende do ângulo de espalhamento). Entretanto, a dependência angular de $f_{i}(q)$ pode ser desprezada, uma vez que o detector está posicionado na região de ângulos pequenos. Então, para baixos ângulos, o fator $f_{i}(q) \approx f_{i}(0) \equiv f_{i}$. Maiores informações podem ser obtidas em (Guinier e Fournet, 1955). 
Antes de determinar as relações para o fator de forma $F_{i}(q)$, vamos realizar mais algumas considerações sobre a intensidade de espalhamento, independente da partícula em estudo.

Do ponto de vista físico, a equação 4 a considera que a intensidade de espalhamento é determinada pela composição do espalhamento de todos pares de elétrons que compõem a amostra. No entanto, do ponto de vista matemático (e físico também!) é interessante separar esta soma (eq. 4a) em duas outras somas. A primeira soma é composta pelos pares de elétrons que pertencem a mesma célula (ou seja, $i=i^{\prime}$ ) enquanto que a segunda é composta pelos elétrons de células diferentes $\left(i \neq i^{\prime}\right)$. Assim, podemos escrever que:

$$
I(q)=V^{-1}\left\langle\sum_{i=1}^{N_{p}}\left|F_{i}(q)\right|^{2}\right\rangle+V^{-1}\left\langle\sum_{i \neq i^{\prime}}^{N_{p}} \sum F_{i}(q) F_{i^{\prime}}^{*}(q) e^{i \vec{q} \cdot\left(\vec{R}_{i}-\vec{R}_{i^{\prime}}\right)}\right\rangle
$$

Se o sistema é composto por $N_{p}$ células idênticas, podemos facilmente ver que o primeiro termo do lado direito desta equação se reduz, enquanto que o segundo termo também se simplifica, de modo que:

$$
I(q)=n_{p}\left\langle\left|F_{i}(q)\right|^{2}\right\rangle+V^{-1}\left\langle F_{i}(q)\right\rangle^{2}\left\langle\sum_{i \neq i^{\prime}}^{N_{p}} \sum e^{\left.i \vec{q} \cdot \vec{R}_{i}-\vec{R}_{i^{\prime}}\right)}\right\rangle
$$

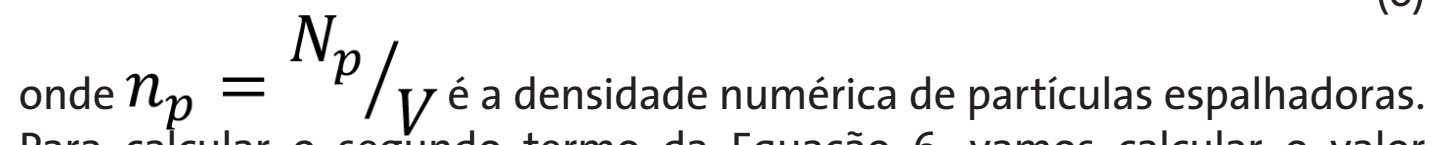
Para calcular o segundo termo da Equação 6, vamos calcular o valor esperado da expressão $e^{i \vec{q} \cdot\left(\vec{R}_{i}-\vec{R}_{i^{\prime}}\right)}$.Podemos então escrever, dentro das aproximações já mencionadas, que:

$$
\left\langle e^{i \vec{q} \cdot \vec{R}_{i j}}\right\rangle=\left\langle\cos \left(\vec{q} \cdot \vec{R}_{i j}\right)\right\rangle+\left\langle i \sin \left(\vec{q} \cdot \vec{R}_{i j}\right)\right\rangle=\left\langle\cos \left(\vec{q} \cdot \vec{R}_{i j}\right)\right\rangle=\frac{\sin \left(q R_{i j}\right)}{q R_{i j}}
$$

onde $\overrightarrow{\boldsymbol{R}}_{i j}=\overrightarrow{\boldsymbol{r}}_{i}-\overrightarrow{\boldsymbol{r}}_{j}$ assim, esta relação é valida se não existir uma direção preferencial para o termo $\vec{q} \cdot\left(\vec{R}_{i}-\vec{R}_{i^{\prime}}\right)$. Além disso, o termo $\left\langle i \sin \left(\vec{q} \cdot \vec{R}_{i j}\right)\right\rangle$ se anula para objetos centro simétricos, ver (Guinier e Fournet, 1955). 
Portanto, este termo se reduz a:

$$
\left\langle\sum_{i \neq i^{\prime}}^{N_{p}} \sum e^{i \vec{q} \cdot\left(\vec{R}_{i}-\vec{R}_{i^{\prime}}\right)}\right\rangle=\iint_{V_{\text {amostra }}} \frac{\sin \left(q R_{i j}\right)}{q R_{i j}} p_{i j} d v_{i} d v_{j}
$$

onde $p_{i j}$ é a probabilidade de encontrarmos dois centros espalhadores, de partículas diferentes, distantes de $R_{i j}$.

Levando em consideração que o sistema é composto por partículas idênticas, adotamos uma partícula de referência (por exemplo, $i=1$ ) e consideramos que a intensidade de espalhamento de $N_{p}$ partículas idênticas é igual a $N_{p}$ vezes a intensidade de espalhamento de uma única partícula. Assim sendo, é possivel escrever que:

$$
\iint_{V_{\text {amostra }}} \frac{\sin \left(q R_{i j}\right)}{q R_{i j}} p_{i j} d v_{i} d v_{j}=N_{p} \int_{V_{a m o s t r a}} \frac{\sin \left(q R_{j}\right)}{q R_{j}} p_{j} d v_{j}
$$

onde $N_{p}$ representa o número total de partículas na solução; $R_{i}$, a distância da partícula $j$ à partícula de referência $e p_{j}$, a probabilidade de encontrarmos a partícula $j$ distante de $R_{j}$ da partícula de referência.

Supondo que as partículas se distribuem isotropicamente ao redor da partícula de referência, a probabilidade $p_{j}$ pode ser escrita como:

$$
p_{j}=4 \pi n_{p} r^{2} g(r) d r
$$

onde $g(r)$ é a função de distribuição radial que relaciona o número de vizinhos ao redor da partícula de referência. Esta função é muito utilizada em teoria de líquidos, para maiores informações ver o capítulo 7 de Chandler, 1987.

Para distâncias suficientemente grandes (onde já não há mais interações com a partícula de referência), a probabilidade de se encontrar alguma partícula se reduz à própria densidade numérica das partículas. Assim, esta contribuição de grandes valores de $r$ deve ser considerada, restando que:

$$
p_{j}=4 \pi n_{p} r^{2} g(r) d r-4 \pi n_{p} r^{2} d r=4 \pi n_{p} r^{2}(g(r)-1) d r
$$


Finalmente, substituindo as Equações 7, 8 e 11 na Equação 5, temos que:

$I(q)=n_{p}\left\langle\left|F_{i}(q)\right|^{2}\right\rangle+V^{-1}\left\langle F_{i}(q)\right\rangle^{2} 4 \pi N_{p} n_{p} \int_{0}^{\infty}(g(r)-1) \frac{\sin (q r)}{q r} r^{2} d r$

ou ainda

$I(q)=n_{p}\left\langle\left|F_{i}(q)\right|^{2}\right\rangle\left\{1+\frac{\left\langle F_{i}(q)\right\rangle^{2}}{\left\langle\left|F_{i}(q)\right|^{2}\right\rangle} 4 \pi n_{p} \int_{0}^{\infty}(g(r)-1) \frac{\sin (q r)}{q r} r^{2} d r\right\}$

Nos livros textos sobre a técnica de SAXS, esta expressão é escrita genericamente como (Guinier e Fournet, 1955; Glatter, 1982; Feigin e Svergun, 1987):

$$
I(q) n_{p} P(q) \overline{S(q)}
$$

ondeP $(q)=\left\langle\left|F_{i}(q)\right|^{2}\right\rangle$ é conhecido como fator de forma da partícula espalhadora, e

$\overline{S(q)}=1+4 \pi n_{p} \frac{\langle F(q)\rangle^{2}}{\left\langle F^{2}(q)\right\rangle} \int_{0}^{\infty}(g(r)-1) r^{2} \frac{\sin (q r)}{q r} d r$

é a função de interferência entre as partículas espalhadoras. É importante salientar que o termo $\mathrm{P}(\mathrm{q})$ está relacionado com espalhamento intrapartícula, enquanto o termo $S$ (q) se relaciona com espalhamento entre partículas espalhadoras. Maiores detalhes podem ser encontradas em (Guinier e Fournet, 1955; Glatter, 1982; Feigin e Svergun, 1987; Barbosa et al., 2013). 


\section{SiSTEMAS NÃO INTERAGENTES:}

\section{Metodologias de ANÁLISE E EXeMplos}

\subsection{Lei de Guinier}

Uma grandeza que pode ser extraída diretamente das curvas de SAXS é o raio de giro ou raio de giração, $R_{g}$, da partícula espalhadora. Tal grandeza relaciona como a massa de uma dada partícula está distribuída ao redor de seu centro de massa.

Tomando a equação $4 b$, juntamente com o resultado obtido na Equação 7

$$
\begin{aligned}
& F_{i}(q)=\int d^{3} \vec{r} \rho_{i}(r) e^{i \vec{q} \vec{r}} \\
& \left\langle\left|F_{i}(q)\right|^{2}\right\rangle=\left\langle F_{i}(q) F_{i}^{*}(q)\right\rangle=\iint_{\text {Volume }} d V_{1} d V_{2} \rho\left(r_{1}\right) \rho\left(r_{2}\right) \frac{\sin \left(q r_{i j}\right)}{q r_{i j}}
\end{aligned}
$$

e ao mesmo tempo escrevendo a função trigonométrica seno como uma série, teremos:

$$
\left\langle\left|F_{i}(q)\right|^{2}\right\rangle=\left\langle F_{i}(q) F_{i}^{*}(q)\right\rangle=\iint_{\text {Volume }} d V_{1} d V_{2} \rho\left(r_{1}\right) \rho\left(r_{2}\right)\left\{1-\frac{q^{2}}{3 !} r_{i j}^{2}+\chi\left(q r_{i j}\right)^{4}\right\}
$$

onde $r_{i j} j$ é a distância entre os centros espalhadores $i$ e $j$ e $\chi\left(q r_{i j}\right)^{4}$ representa os termos de ordens superiores.

Reescrevendo o termo à direita da Equação acima até segunda ordem, temos que:

$$
\iint_{\text {Volume }} d V_{1} d V_{2} \rho\left(r_{1}\right) \rho\left(r_{2}\right)-\frac{q^{2}}{6} \iint_{\text {Volume }} d V_{1} d V_{2} \rho\left(r_{1}\right) \rho\left(r_{2}\right) r_{i j}{ }^{2}
$$

o primeiro termo desta soma é $F^{2}(0)$. É interessante aqui não descrever as posições entre os centros espalhadores, mas sim a posição de cada centro espalhador com relação ao centro de massa (eletrônico) da partícula, como mostra o esquema da Fig. 3. 


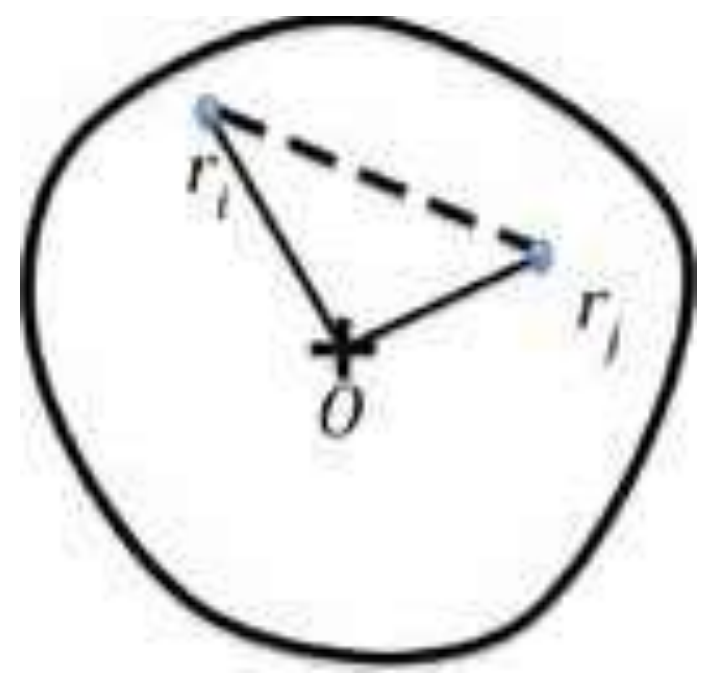

Figura 3. Esquema de uma partícula de espalhamento:O representa a posição do centro de massa eletrônico da partícula, enquanto que $r_{i}$ e $r_{j}$ as posições dos centros espalhadores i e $j$.

$r_{i j}=r_{i}-r_{j}$

Assim, $\overrightarrow{O r}$ é a distância do centro de espalhamento $j$ ao centro de massa eletrônico da partícula. Então, utilizando as leis dos cossenos é possível escrever que:

$r_{i j}^{2}=\left|\overrightarrow{O r_{l}}\right|^{2}+\left|\overrightarrow{O r_{j}}\right|^{2}-2\left|\overrightarrow{O r_{l}}\right|\left|\overrightarrow{O r_{j}}\right| \cos \left(\varphi_{i j}\right)$

,sendo $\varphi_{i j}$ o ângulo entre os vetores $\overrightarrow{O r_{l}}$ e $\overrightarrow{O r_{J}}$

Aosubstituir $r_{i j}^{2}$ na equação 15, teremos que os dois primeiros termos geram contribuições idênticas. Já o terceiro termo não terá nenhuma contribuição naeq. 15 (a integral angular será nula,uma vez que $0<\varphi_{i j}<2 \pi$ ).

Assim, temos que:

$\left|F_{i}(q)\right|^{2}=F^{2}(0)-2 \frac{q^{2}}{6} \iint_{\text {Volume }} d V_{1} d V_{2} \rho\left(r_{1}\right) \rho\left(r_{2}\right)\left|\overrightarrow{O r_{j}}\right|^{2}$ 
ou ainda,

$\left|F_{i}(q)\right|^{2}=F^{2}(0)\left\{1-\frac{q^{2}}{3} \frac{\iint_{V o l u m e} d V_{1} d V_{2} \rho\left(r_{1}\right) \rho\left(r_{2}\right)\left|\overrightarrow{O r_{J}}\right|^{2}}{F^{2}(0)}\right\}$

É interessante definir aqui, por analogia à mecânica clássica, o raio de giro (eletrônico):

$$
R_{g}^{2}=\frac{\iint_{V o l u m e} d V_{1} d V_{2} \rho\left(r_{1}\right) \rho\left(r_{2}\right)\left|\overrightarrow{O r_{J}}\right|^{2}}{\iint_{\text {Volume }} d V_{1} d V_{2} \rho\left(r_{1}\right) \rho\left(r_{2}\right)}
$$

Então, é possível reescrever a intensidade de espalhamento, na região de $q \rightarrow 0$ como sendo:

$$
\left|F_{i}(q)\right|^{2}=F^{2}(0) e^{\frac{-q^{2} R_{g}^{2}}{3}}
$$

que também pode ser escrita como:

$$
I(q)=I(0) e^{\frac{-q^{2} R_{g}^{2}}{3}}
$$

Esta equação é conhecida como Lei de Guinier (Guinier e Fournet, 1955).

A determinação experimental do raio de giro da partícula em estudo pode então ser realizada a partir do ajuste linear do gráfico de $\ln (I(q)) \times q^{2}$. Como um exemplo, apresentamos na Figura 4a, as curvas de espalhamento do monômero da toxina Sticholisina I, StI, assim como de uma possível forma dimérica, ambas calculadas utilizando o software SASMOL (Ortore et al. 2009) a partir das coordenadas cristalográficas. Note que $I(0)$ para o dimero é maior que do monômero, pois I(o) é proporcional à massa molecular da proteína. Portanto, através do valor de I(o) podemos inferir sobre estados oligoméricos de proteínas. A Figura $4 \mathrm{~b}$ apresenta o gráfico de Guiner, $\ln (I(q)) \times q^{2}$ para $q \rightarrow 0$, sendo que do ajuste linear (eq. 19) resultam os valores de $\mathrm{Rg}=15,6 \AA$ e $\mathrm{Rg}=24,0 \AA$ para o monômero e o dímero, respectivamente. 

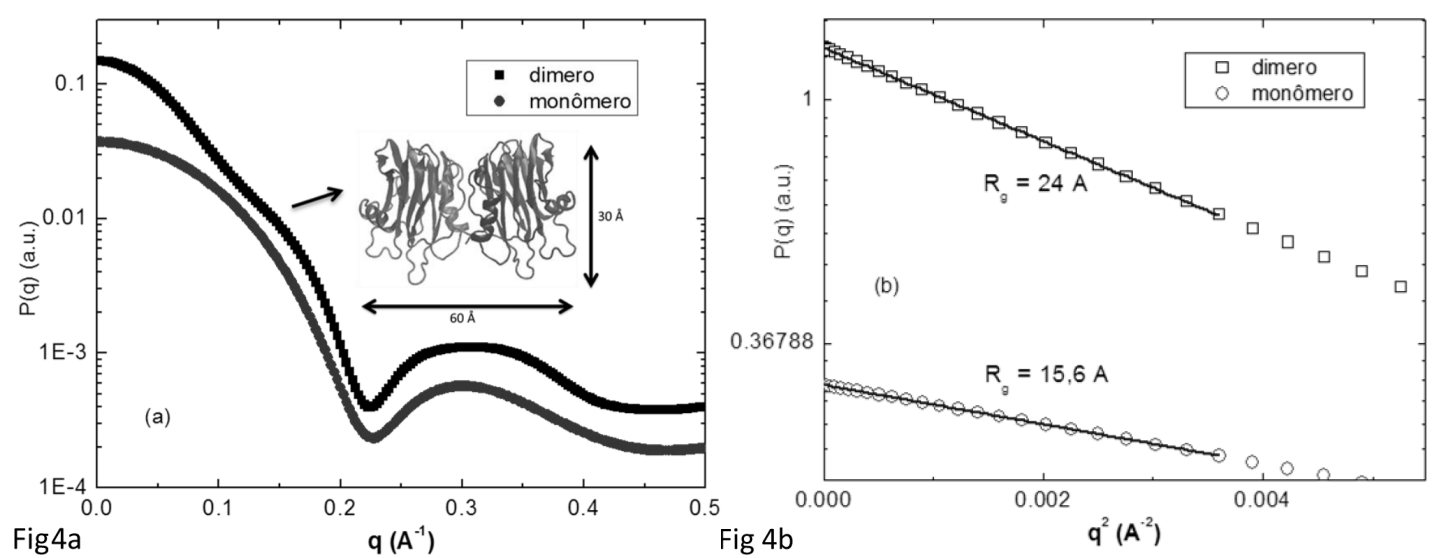

Figura 4. (a) curvas de SAXS de monômero e dimero de Sticholisina I; (b) respectivos raios de giro, $R_{g^{\prime}}$ calculados via gráfico de Guinier, $\ln (I(q)) \times q^{2}$ para $q \rightarrow 0$.

É importante ressaltar que a aproximação de Guinier (eqs. 18-19) vale para a condição que $q R_{g} \leq 1.3$, ou seja, é válida apenas para uma região de pequenos valores de q. Além disso, a lei também é apenas válida para sistemas não interagentes, ou seja, $S(q) \rightarrow 1$ na eq. 14 e $I(q)$ é diretamente proporcional ao fator de forma $\mathrm{P}(\mathrm{q})$ da partícula espalhadora.

\subsection{Lei de Porod}

Enquanto a lei de Guinier é válida na região de $q \rightarrow 0$, Porod mostrou que no limite de $q$ grandes, a intensidade de espalhamento decai com $q^{-4} \mathrm{e}$ está diretamente correlacionada com o contraste de densidade eletrônica homogêneo entre a partícula e o meio $(\Delta \rho)$ e a razão entre a superfície (S) e o volume (V) da partícula espalhadora. Sendo assim, a função que descreve a intensidade na região de $q$ estudada é dada por (Guinier e Fournet, 1955; Glatter, 1982; Feigin e Svergun, 1987; Barbosa et al., 2013):

$$
I(q)_{q \rightarrow \infty}=n_{p} P(q)=\frac{2 \pi(\Delta \rho)^{2}}{q^{4}} \frac{s}{V}
$$

conhecida como lei de Porod e

$$
\frac{S}{V}=\pi \frac{\lim q^{4} I(q)}{\int_{0}^{\infty} q^{2} I(q) d q}
$$



onde $S / V=$ superfície específica da partícula e $\int_{0}^{\infty} q^{2} I(q) d q$ é
conhecido como invariante de Porod.

A lei de Porod pode ser generalizada para superfícies fractais (Teixeira, 1988), do mesmo modo que pode ser modificada se a interface não é abrupta ou se a densidade eletrônica no interior da partícula não é homogênea (Kaler, 1988). Em todos estes casos, a intensidade de espalhamento decai com uma potência menor que $4\left(\mathrm{I}(q) \infty \mathrm{q}^{-\mathrm{n}}\right.$, com $\left.\mathrm{n}<4\right)$. Um caso particular é o de proteínas desenoveladas que se comportam como polímeros gaussianos (ver representação de Kratky abaixo), com comportamento de fractal de superfície. Neste caso, I(q) $\infty \mathrm{q}^{-2}$ na regiãode $q$ grandes.

Ainda, para o caso de partículas ou agregados muito grandes, cuja dimensão máxima ultrapasse o limite de detecção da técnica de SAXS, às vezes podemos observar apenas um comportamento do tipo $I(q) \infty q^{-4}$ na região de $q$ analisada (mesmo ângulos pequenos), indicando que a partícula espalhadora tem interfaces bem definidas em relação ao solvente.

\subsection{Representação de Kratky}

Outra ferramenta muito utilizada no estudo de proteínas, polímeros e sistemas coloidais é o chamado gráfico de Kratky, que utilizou a expressão desenvolvida por Debye para o estudo de polímeros em solução:

$$
P_{\text {macro }}(q)=2 \frac{e^{-x}+x-1}{x^{2}}, x=\left(q R_{g}\right)^{2}
$$

onde $P_{\text {macro }}(q)$ é o fator de forma de uma macromolécula em solução. É interessante salientar que o início da curva de espalhamento é governado pela Lei de Guinier (Equação 19). Ou seja,

$\lim _{x \rightarrow 0}\left\{2 \frac{e^{-x}+x-1}{x^{2}}\right\}=1-\frac{x}{3} \sim e^{\frac{-x}{3}}, \quad x=\left(q R_{g}\right)^{2}$

Entretanto, para grandes valores de $q$, a Equação 22 não obedece à lei de Porod, mas sim $P_{\text {macro }}(q \rightarrow \infty) \propto q^{-2}$. Esta informação é muito útil, por exemplo, no estudo do processo de desenovelamento e enovelamento de proteínas. Isto é, em um gráfico de $I(q) q^{2}$ versus $q$, se uma 
proteína estiver desenovelada (se assemelhando a um polímero 'random coil'em solução), deverá existir uma região constante (um platô) para certos valores de $q$. Por outro lado, se a proteína estiver em uma forma globular, o fator de forma deverá obedecer a lei de Porod, ou seja, um decaimento com $q^{-4}$, conferindo ao gráfico de Kratky uma forma de "sino", cuja posição do pico depende do raio de giro da mesma. A Fig. 5 a apresenta o gráfico de Kratky correspondente à Fig. $4 a$ dos estados enovelados da StI na forma monomérica e dimérica, enquanto a Fig. $\mathbf{5} \boldsymbol{b}$ apresenta o gráfico de Kratky da proteína albumina de soro bovino, BSA, no estado enovelado (linha preta em forma de sino), desenovelamento parcial (linha cinza) e desenovelado (linha preta) devido a adição de concentrações crescentes de uréia (dados extraídos de Barbosa et al., 2013).
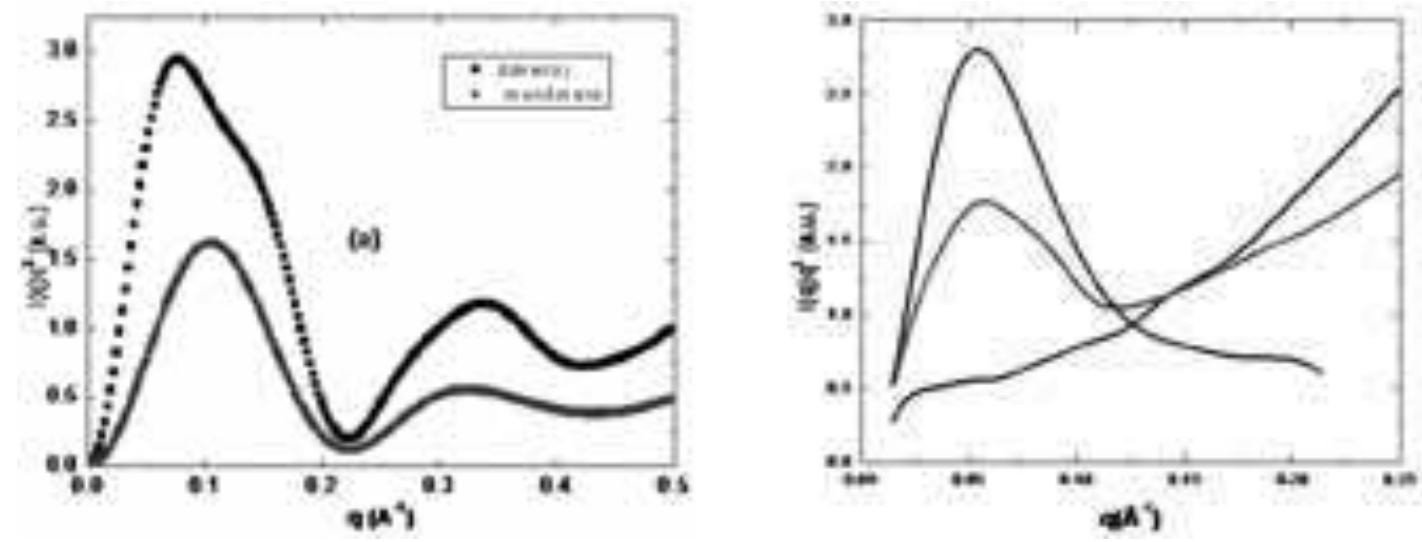

Figura 5. Gráfico de Kratky (a): estado enovelado de StI na forma monomérica e dimérica (Fig. 4a); (b) Albumina de Soro Bovino, BSA, em diferentes conformações: nativa globular (linha preta em forma de sino), semi-flexivel (linha cinza, na presença de $3 M$ de uréia) e desenovelada (linha preta, na presença de $8 \mathrm{M}$ uréia).

\subsection{Função de Distribuição de Distâncias, $p(r)$}

A função de distribuição de distâncias, também chamada de função $p(r)$, é proporcional à distribuição de distâncias entre elementos espalhadores dentro de uma dada partícula. Para sistemas não interagentes, uma transformada de Fourier inversa conecta a função $p(r)$ com a função $P(q)$ (Guinier e Fournet, 1955; Glatter, 1982; Feigin e Svergun, 1987; Barbosa et al., 2013) e, como consequência, a função $I(q)$ : 


$$
p(r)=\frac{1}{2 \pi^{2}} \int_{0}^{\infty} I(q) \cdot q r \cdot \sin (q r) d q
$$

A função $p(r)$ nos fornece informações sobre a geometria da partícula espalhadora, sendo que $p(r)=0$ para a $r=D_{\text {max }}$, dimensão máxima da partícula. É possível também, através da $p(r)$, obter o valor do raio de giro da partícula, através da relação (Guinier e Fournet, 1955; Glatter, 1982; Feigin e Svergun, 1987):

$$
R_{g}^{2}=\frac{\int_{0}^{D_{m a ́}} p(r) r^{2} d r}{2 \int_{0}^{D_{m a ́ x}} p(r) d r}
$$

Assim, de um análise direta da curva de SAXS via a função $p(r)$, podemos obter informação da $D_{\text {max }}, R g$ e geometria (globular, fibrilar, oligomérica,etc). Para maiores detalhes ver refs.(Guinier e Fournet, 1955; Glatter, 1982; Feigin e Svergun, 1987; Barbosa et al., 2013)

Como um exemplo da potencialidade da análise da função $p(r)$, a Figura 6 apresenta as curvas teóricas de espalhamento do monômero e de dois possíveis dímeros de Stl, obtidos a partir dos dados cristalográficos utilizando-se o programa SASMOL (Ortore et al. 2009). A diferença entre esses dois dímeros se dá na posição relativa entre os monômeros da proteína. Percebe-se que as curvas de espalhamento são muito similares. Como consequência, é muito difícil diferenciar entre as possiveis estruturas diméricas a partir da função $I(q) \times q$. Entretanto, as funções $p(r)$ (inset na Figura) mostram diferenças: a função $p(r)$ do dímero 2 apresenta um ombro em $r \sim 45 \AA$ (seta no inset da Figura 6), não presente na função $p(r)$ do dímero 1, embora ambos os dímeros tenham a mesma dimensão máxima $60 \AA$ (Figura 4) e $R g=24 \AA$, em boa concordância com $R_{g}$ de Guinier (Fig. 4).
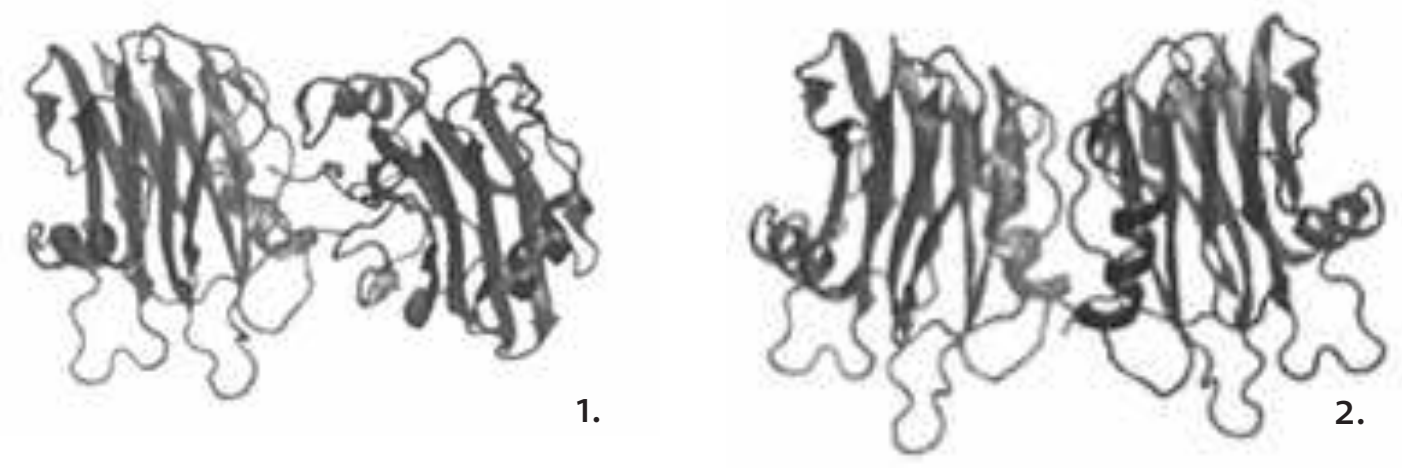


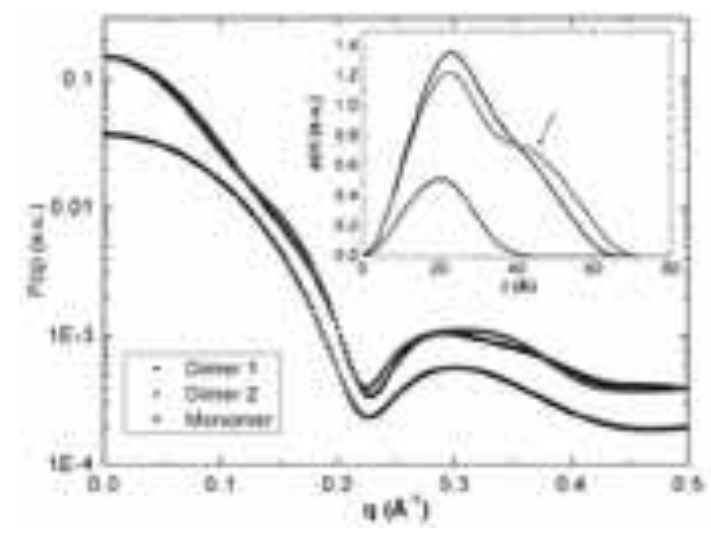

Figura 6. - (1) e (2) estruturas diméricas de St I obtidas por modelagem molecular a partir dos dados cristalográficos do monômero.; curvas teóricas de SAXS calculadas a partir de dados cristalográficos utilizando-se o programa SASMOL(Ortore et al., 2009) e respectivas funções p(r) (inset).

Não podemos nos esquecer que proteínas podem compor arranjos maiores que dímeros. A hemoglobina humana, por exemplo, é composta por 4 monômeros idênticos, e esse tetrâmero é responsável pelo transporte de $\mathrm{O} 2$ pelo nosso corpo. Mechaly et al. (2012), estudaram o arranjo de uma toxina formadora de poros chamada de FraC da anêmona marinha Actinia fragacea em presença de membranas lipídicas. Os autores propõem que em presença de membranas as toxinas se arranjam em anéis compostos por 9 monômeros, sendo que no centro deste anel se forma um poro que causa danos na membrana celular. Embora essas estruturas sejam obtidas em membranas lipídicas, é importante mencionar as diferenças entre as curvas de SAXS de estruturas como o nonâmero e o monômero e o dímero mostrados anteriormente. Assim, a Fig. 7 apresenta um modelo semelhante para a Stl obtido por simulação. Não só a forma da curva de SAXS se altera de forma significativa em relação as curvas do monômero e do dímero de Stl (Figs. 4 e 6), mas também o valor da intensidade extrapolada ao ângulo zero, $I(q \rightarrow 0)$, relacionada a massa molecular do agregado proteico. Além disso, note a diferença apreciável da função $p(r)$ que apresenta frequências de distância significativas para $20 \AA<r<40 \AA$ como no caso de monômeros e dímeros (Fig. 6) e frequências maiores para o nonâmero $\operatorname{com} D_{\text {max }}=120 \AA$. 


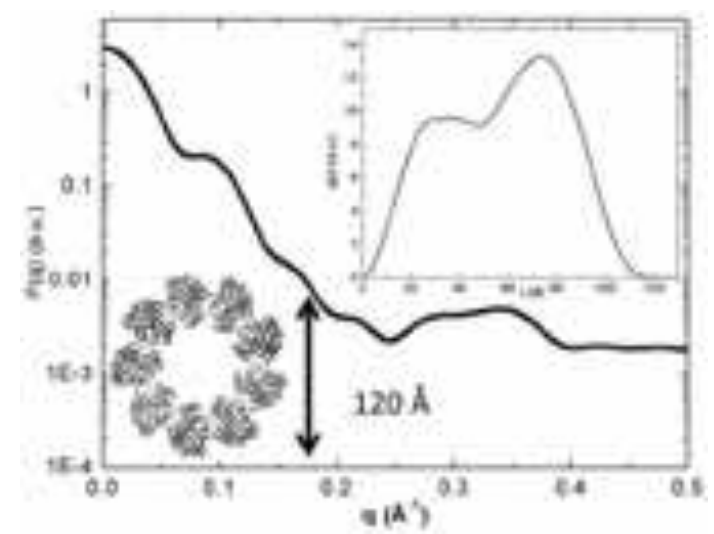

Figura 7. Curva teórica de SAXS de um arranjo contento 9 monômeros de StIe respectiva função $p(r)$ (inset).

\subsection{Análise de curvas de SAXS para}

\section{sistemas multiméricos.}

A técnica de SAXS permite ainda estudar sistemas compostos por diferentes partículas espalhadoras, por exemplo, um sistema composto por monômeros, dímeros e oligômeros. Para tanto, é necessário considerar uma combinação linear dos modelos, tal que (Barbosa et al., 2013):

$$
I(q)=\sum_{i} w_{i} P_{i}(q)
$$

onde $P_{i}(q)$ é o fator de forma correspondente a cada modelo utilizado e $w_{i} o$ respectivo peso do modelo na combinação linear de intensidades.

Na Fig. 8 apresentamos como exemplo a curva experimental da proteína septina $2 \mathrm{G}$ (SEPT2G) e o melhor ajuste para os dados experimentais obtidos através do programa GENFIT (Spinozzi, et al., 2014). Apresentamos também a contribuição de cada um dos modelos utilizados nesse ajuste: dímero (linha contínua, $w=67 \%$ ), cilindro (linha tracejada, $w=2,6 \%$ ) e Porod (linha pontilhada, $w=30,4 \%$ ). Nesse caso, o modelo de Porod representa agregados maiores que o limite observado pela técnica de SAXS.

Podemos perceber que a contribuição do dímero (linha contínua) mostra-se dominante na região de $q>0,035 \AA^{-1}$. Foi necessária a adição de um espalhamento parasito (linha pontilhada e tracejada) ao observarmos que o comportamento da região $q>0,15 \AA^{-1}$ é dada basicamente pelo dímero, a menos de uma pequena diferença entre a curva experimental e a simulada do dímero. 


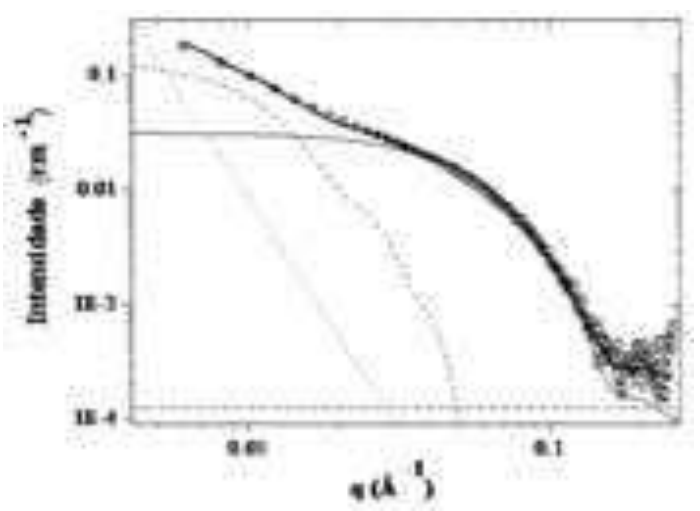

Figura 8. Exemplo de ajuste da curva de SAXS para a proteina SETP2G a uma concentração de $1 \mathrm{mg} / \mathrm{mL}$ e $\mathrm{T}=25^{\circ} \mathrm{C}$, utilizando os modelos de dimero (linha continua), cilindro (linha tracejada) e Porod (linha pontilhada). A linha tracejada e pontilhada corresponde a um fundo constante.

A contribuição de agregados grandes, ajustados pelo modelo de Porod (Equações 20 e 21) é observada na região de valores pequenos de $q$. Entretanto, a faixa de $q<0,035 \AA^{-1}$ não é proporcional à $q^{-4}$. Com isso, podemos ver que o modelo de cilindro (curva tracejada) também tem uma grande contribuição nessa região de $q$.

\section{CONCLUSÕES}

Como vimos ao longo deste capitulo, a técnica de SAXS pode ser uma importante ferramenta para o estudo de proteínas em solução. Não apenas estruturas monoméricas podem ser acessadas via técnica de SAXS, mas também a presença de estados oligoméricos, obtendo-se os percentuais de cada uma das espécies. Mais ainda, análises combinadas da curva de SAXS, chamadas modelo-independentes, podem dar informações importantes como simetria da proteína, estados de enovelamento e desenovelamento, e dimensões como raio de giro e extensão máxima da proteína. 


\section{REFERENCIAS}

Barbosa, L. R. S., Spinozzi, F., Mariani, P. and Itri, R. (2013) Small-Angle X-Ray Scattering Applied to Proteins in Solution, in Proteins in Solution and at Interfaces: Methods and Applications in Biotechnology and Materials Science (eds J. M. Ruso and Á. Piñeiro), John Wiley \& Sons, Inc.,

Chandler, D. (1987). Introduction to modern statistical mechanics, Oxford University Press.

Feigin, L.A. e Svergun, D. I. (1987) Structural Analysis by small angle X-ray and Neutron scattering. Plenum Press.

Glatter, O. (1982), Small Angle X-ray Scattering, Academic Press.

Guinier, A., Fournet, G., (1955) Small Angle Scattering of X-Rays. Wiley, New York.

Kaler, E. W. (1988) Small-angle scattering from colloidal dispersions," Journal of Applied Crystallography, 21(6), 729-736.

Mechaly, A.E., Bellomio, A., Morante, K., Agirre, J., Gil-Cartón, D., Valle, M., González-Mañas, J.M., Guérin, D.M.A., (2012) Pores of the toxin FraC assemble into $2 \mathrm{D}$ hexagonal clusters in both crystal structures and model membranes, Journal of Structural Biology,180(2), 312-317.

Ortore, M. G., Spinozzi, F., Mariani, P., Paciaroni, A., Barbosa, L. R. S., Amenitsch, H., Steinhart, M., Ollivier, J., and Russo, D. (2009) Combining structure and dynamics: nondenaturing high-pressure effect on lysozyme in solution. J. R. Soc. Interface 6, S619-S634.

Spinozzi, F., Ferrero, C., Ortore, M. G., Antolinos, De, M. and Mariani, P. , (2014), GENFIT: software for the analysis of small-angle X-ray and neutron scattering data of macromolecules in solution. J. Appl. Cryst. 47, 1132-1139.

Teixeira, J. (1988) Small-Angle Scattering by Fractal Systems. J. Appl. Cryst.21, 781-785. 